\title{
Caracterización de los progenitores neurales de retina del pez cebra adulto
}

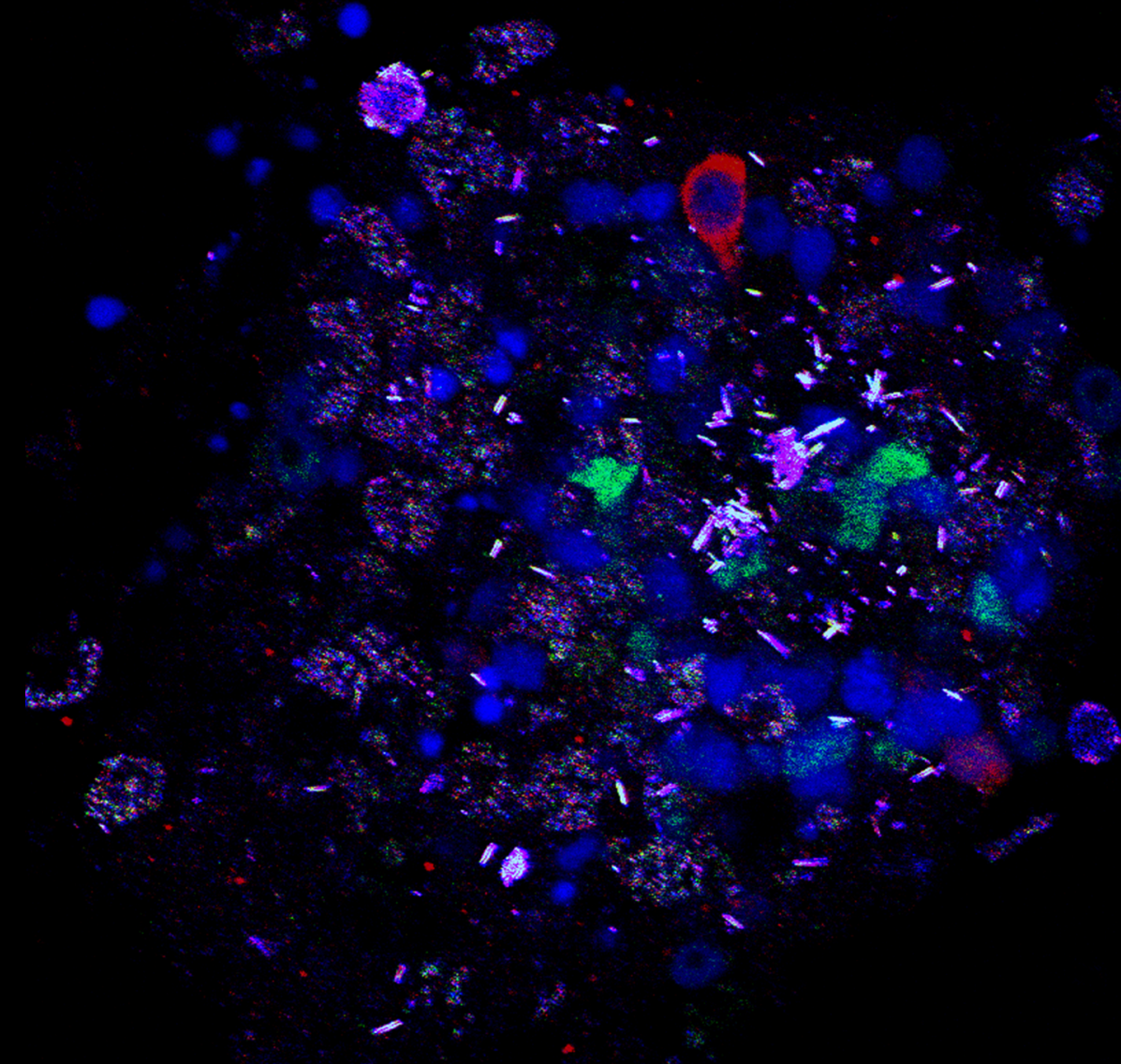

Maite Ogueta Gutiérrez

Salamanca, 2013

-TESIS DOCTORAL- 

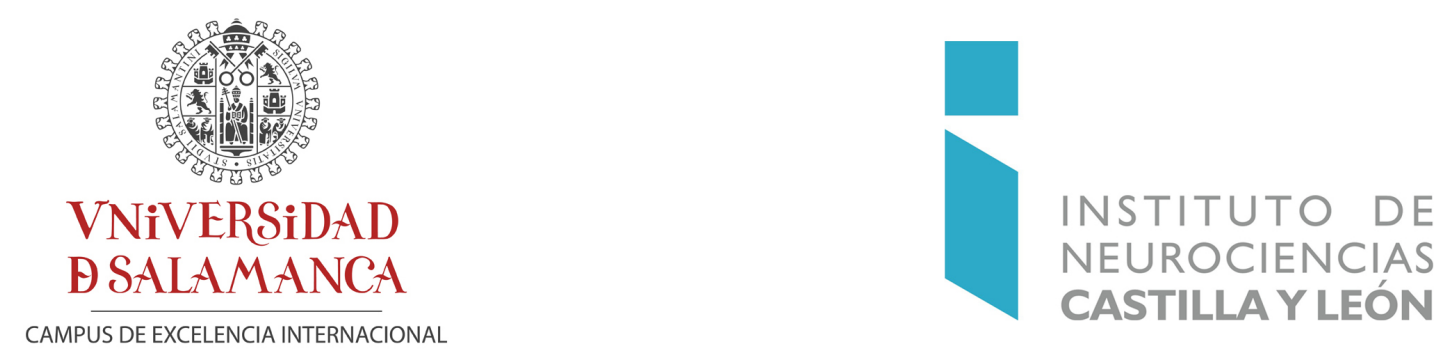

TESIS DOCTORAL

\section{Caracterización de los progenitores neurales de retina del pez cebra adulto}

Maite Ogueta Gutiérrez 

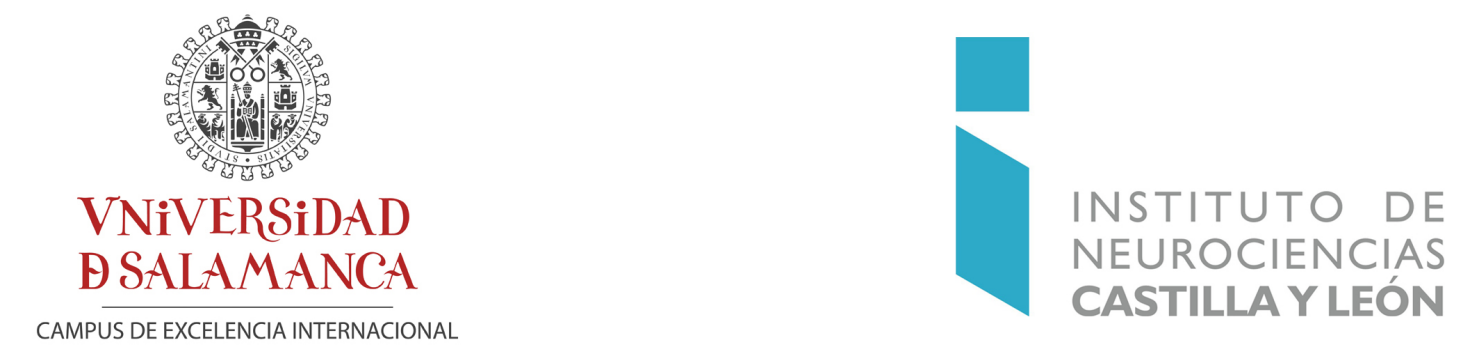

\title{
Caracterización de los progenitores neurales de retina del pez cebra adulto
}

\author{
Tesis presentada por \\ Maite Ogueta Gutiérrez \\ para optar al título de \\ Doctora en Biología
}

Los Directores

Ma Rosario Arévalo Arévalo

Juan M. Lara Pradas 

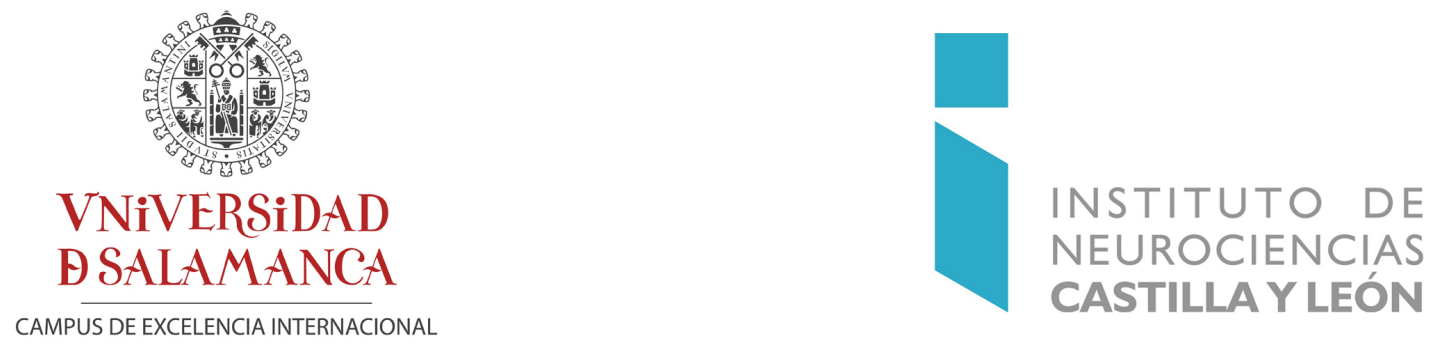

Juan Lara Pradas, Catedrático de Biología Celular y Rosario Arévalo Arévalo, Profesora Titular de Biología Celular de la Universidad de Salamanca

\section{HACEN CONSTAR}

Que el presente trabajo titulado "Caracterización de los progenitores neurales de retina del pez cebra adulto", ha sido realizado por la licenciada en Biología Dña. Maite Ogueta Gutiérrez en el Departamento de Biología Celular y Patología de la Universidad de Salamanca y en el Instituto de Neurociencias de Castilla y León.

Que ha sido desarrollado bajo nuestra dirección y dentro del programa de doctorado de Neurociencias de nuestra Universidad.

Que, en nuestra opinión, reúne todos los requisitos científicos y formales para ser defendido como Tesis Doctoral y así optar al grado de Doctor por la Universidad de Salamanca.

Para que así conste, expedimos el presente documento.

La directora

El director

Ma Rosario Arévalo Arévalo

Juan M. Lara Pradas

VNIVERSITAS

STVDII

SALAMANIINi

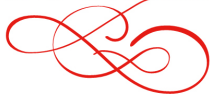


Cuando emprendas tu viaje hacia Ítaca debes rogar que el viaje sea largo, lleno de peripecias, lleno de experiencias... 
Este trabajo ha sido posible gracias a la ayuda directa o indirecta de muchas personas.

Al Prof. Dr. José Aijón por haber permitido mi integración en el grupo de trabajo que dirige, y haberme sugerido el tema de investigación.

A mis directores de la tesis, la Dra. Rosario Arévalo y el Prof. Dr. Juan Lara, por el apoyo mostrado durante estos años, por las sugerencias y correcciones. Gracias por la confianza depositada en mi trabajo

A la Dra. Concepción Lillo, a la Dra. Almudena Velasco y al Dr. Ángel Porteros, por compartir sus conocimientos, que en gran medida han mejorado este trabajo.

Al grupo del Dr. Chichung Lie, porque además de llevarme a la Oktoberfest me enseñaron todo acerca de los cultivos de neuroesferas. En especial a Tobi, por su paciencia y su confianza en mi.

Al laboratorio de la Dra. Laure Bally-Cuif, especialmente a Jakob, por hacerme ver que el pez cebra es algo más que la retina.

A la Dra. Rosario Sánchez. Ella me enseñó todo lo que sabía, y yo he seguido lo mejor que he podido su camino. A ver hasta donde llega.

A la Dra. Henrike Scholz, con la que aprendí mucho acerca del cerebro, ya que gracias a la pasión que me transmitió por la neurociencia empecé y termino esta Tesis Doctoral.

A mis compañeros del INCyL. A Miguel y Saúl, que llevamos ya unos cuantos años juntos, por todas las experiencias compartidas, las buenas y las no tan buenas. A Marta, que aunque ahora anda por las Alemanias, me ha echado una mano siempre que ha podido. A Fernando, por hacer del día a día del laboratorio algo interesante. A Bego, por las comidas compartidas, por los desahogos y las risas. A Hector, Antonio, Rafa, Marcelo, Laura, porque sin todos vosotros esto no sería lo mismo.

A los compañeros del comité de Intermón Oxfam de Salamanca, por hacerme creer que un mundo más justo es posible. A los que están y los que han pasado por aquí, que son muchos. Unas gracias especiales a Ximena, Carlos, Mercedes, Ana, Sofía, Marta, Carmen y Mar (por dos).

A los de Würzburg, a Ebru, Laura, Mar, Grigorios, Jose y Alejandro por haber hecho de la estancia alemana una de las mejores experiencias.

A la cuadri, porque aun sin entenderme, han estado ahí para charlar y compartir. En especial a Ainara y Maite, por todo lo que hemos pasado juntas y todo lo que nos queda. 
A Luis, por aguantarme durante la fase de más estrés sin quejarse demasiado, apoyándome en todo lo que le ha sido posible.

A mi familia, por estar ahí desde el principio de los tiempos. A Mikel, el próximo Dr. Ogueta, por las discusiones de hermanos y por su apoyo. A mis padres, por estar conmigo en todas las decisiones. Por transmitirme valores y por enseñarme la importancia del conocimiento científico.

Este trabajo ha sido financiado por el Programa de Ayudas al Personal Investigador de Reciente Titulación Universitaria de la Junta de Castilla y León, por el Ministerio de Ciencia e Innovación (BFU2009-11179) y por la Consejería de Sanidad de la Junta de Castilla y León. 


\section{Índice general}

$\begin{array}{lll}\text { Índice general } & \text { IV }\end{array}$

1. Introducción 1

1.1. La retina de teleósteos . . . . . . . . . . . . . . . . . . . . . 3

1.1.1. Células de la retina . . . . . . . . . . . . . . . . 5

1.2. Formación de la retina . . . . . . . . . . . . . . . . . . . . . 14

1.2.1. Retinogénesis . . . . . . . . . . . . . . . . . . . . . . 14

1.2.2. Neurogénesis en la retina adulta de teleósteos . . . . . . . . . . . . 15

1.3. Enfermedades retinianas y terapia celular . . . . . . . . . . . . . . . 22

1.4. Detección y caracterización de las células progenitoras . . . . . . . . . . . 23

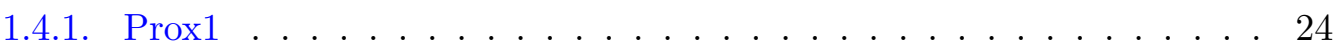

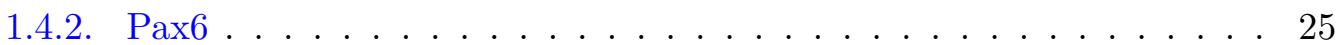

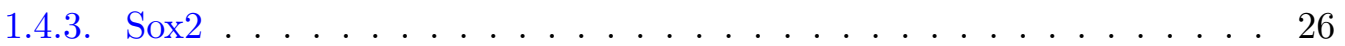

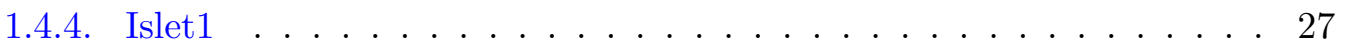

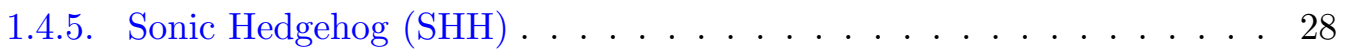

1.4.6. Nestina . . . . . . . . . . . . . . . . . . . . . . 29

1.4.7. Calretinina . . . . . . . . . . . . . . . . . . . 29

2. Justificación, hipótesis y objetivos 31 
3.1. Animal de experimentación . . . . . . . . . . . . . . . . . 37

3.1.1. Danio rerio (Hamilton, 1822) . . . . . . . . . . . . . 37

3.1.2. Manipulación de los animales . . . . . . . . . . . . . . 37

3.1.3. Pinzamiento del nervio óptico . . . . . . . . . . . . . . 38

3.2. Procesamiento de los ojos para estudio de secciones . . . . . . . . . . . 38

3.2.1. Inyección de BrdU . . . . . . . . . . . . . . . . 38

3.2.2. Extracción del ojo . . . . . . . . . . . . . . . . . . . 39

3.2.3. Fijación y corte . . . . . . . . . . . . . . . . . 39

3.3. Cultivo de células retinianas . . . . . . . . . . . . . . . . . . . . . . 40

3.3.1. Pretratamiento de los animales . . . . . . . . . . . . . . . . 40

3.3.2. Extracción y disgregación de las retinas . . . . . . . . . . . . . . 40

3.3.3. Cultivo de las células . . . . . . . . . . . . . . . . . . . . . 41

3.3.4. Estudio de la viabilidad del cultivo mediante el ensayo MTT . . . . 42

3.4. Inmunohistoquímica . . . . . . . . . . . . . . . . . . . 43

3.4.1. Método avidina-biotina-peroxidasa . . . . . . . . . . . . . 43

3.4.2. Método inmunofluorescente . . . . . . . . . . . . . . . 44

3.4.3. Controles de la técnica inmunohistoquímica . . . . . . . . . . . 45

3.5. Inmunocitoquímica de cultivos . . . . . . . . . . . . . 46

3.5.1. Fijación de las neuroesferas . . . . . . . . . . . . . . 46

3.5.2. Inmunocitoquímica . . . . . . . . . . . . . . . . 47

3.6. Western blot . . . . . . . . . . . . . . . . . 47

3.7. Hibridación in situ . . . . . . . . . . . . . . . . . . . . . . . . 50

3.7.1. Síntesis de las ribosondas . . . . . . . . . . . . . . . 50

3.7.2. Diseño de la sonda de nestina . . . . . . . . . . . . . . . . 52 
3.7.3. Protocolo de hibridación in situ . . . . . . . . . . . . . . 53

3.7.4. Controles de la técnica de hibridación in situ . . . . . . . . . . . . 54

3.8. Análisis de imagen . . . . . . . . . . . . . . . . . . 55

3.9. Análisis estadístico . . . . . . . . . . . . . . . . 55

$\begin{array}{ll}\text { 4. Resultados } & 57\end{array}$

4.1. Detección de células mitóticamente activas . . . . . . . . . . . . . 59

4.1.1. Localización de células en división . . . . . . . . . . . . . . . 59

4.1.2. Estudio de los progenitores a largo plazo . . . . . . . . . . . . 61

4.2. Inmunorreactividad para marcadores neurales en la retina madura . . . . . 67

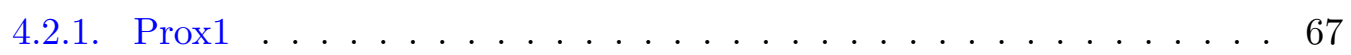

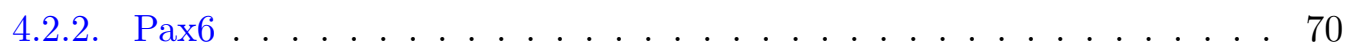

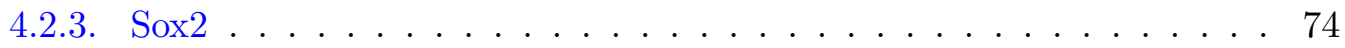

4.3. Detección de ARNm mediante la técnica de hibridación in situ . . . . . . . 77

4.3.1. Islet1 . . . . . . . . . . . . . . . . . . 77

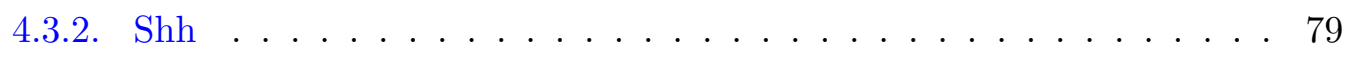

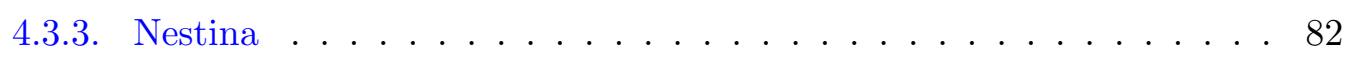

4.4. Estudio in vitro de las células progenitoras . . . . . . . . . . . . . 87

4.4.1. Adaptación del protocolo de cultivo de las células progenitoras de retina de pez cebra . . . . . . . . . . . . . . 87

4.4.2. Evolución de las células progenitoras en cultivo . . . . . . . . . . 93

4.4.3. Viabilidad celular del cultivo . . . . . . . . . . . . . . . 95

4.5. Inmunocitoquímica sobre neuroesferas . . . . . . . . . . . . . . 96

4.5.1. Detección de división celular mediante BrdU . . . . . . . . . . . 96

4.5.2. Expresión de Prox1 f . . . . . . . . . . . . . . . . 99

4.5.3. Expresión de Pax6 . . . . . . . . . . . . . . . . . . . . . 99 
4.6. Diferenciación de las neuroesferas . . . . . . . . . . . . . . . . . . . . 104

5.1. Estudio de la proliferación celular . . . . . . . . . . . . . . . . . . . . . 109

5.1.1. Estudio cuantitativo de la tasa de división de los progenitores . . . . 111

5.2. Caracterización de los progenitores retinianos . . . . . . . . . . . 113

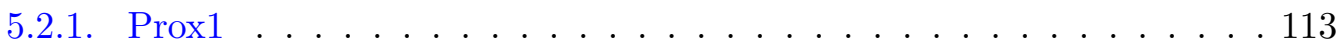

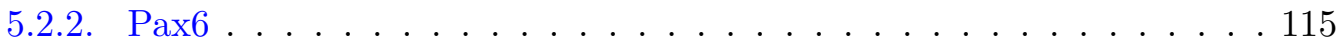

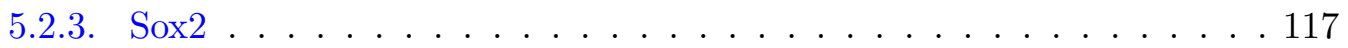

5.2.4. Islet1 . . . . . . . . . . . . . . . . . . . . 120

5.2 .5$. Shh . . . . . . . . . . . . . . . . . 122

5.2.6. Nestina . . . . . . . . . . . . . . . . . . . . . . . . 124

5.3. Cultivo primario de células progenitoras retinianas . . . . . . . . . . . . 127

5.4. Caracterización de las neuroesferas . . . . . . . . . . . . . . . 130

5.4.1. Incorporación de BrdU . . . . . . . . . . . . . . . . . . . 130

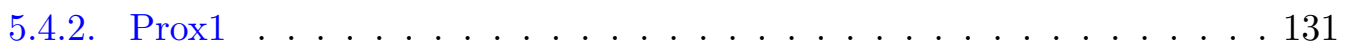

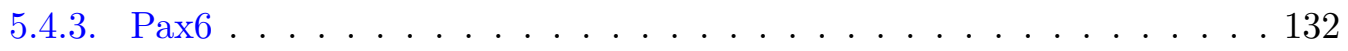

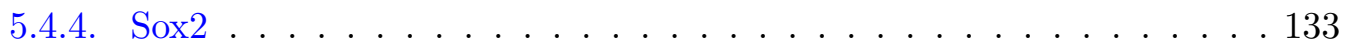

5.5. Diferenciación de las neuroesferas en cultivo . . . . . . . . . . . . . 134

$\begin{array}{ll}\text { 6. Conclusiones } & 137\end{array}$

$\begin{array}{ll}\text { 7. Bibliografía } & 141\end{array}$ 


\section{Abreviaturas}

ABC Complejo Avidina-biotina

APS Persulfato amónico

BCIP 5-bromo-4 cloro-3 indol fosfato

bFGF Factor de crecimiento de fibroblastos básico

bHLH Hélice-bucle-hélice básica

BrdU 5-bromo-2-desoxiuridina

BSA Albúmina sérica bovina

CCG Capa de las células ganglionares

CFNO Capa de fibras del nervio óptico

CNE Capa nuclear externa

CNI Capa nuclear interna

CNTF Factor neurotrófico ciliar

CPE Capa plexiforme externa

CPI Capa plexiforme interna

CR Calretinina

DAB 3,3'-diaminobenzidina

DAPI 4',6-diamidino-2-fenilindol

DMAE Degeneración macular asociada a la edad

DMSO Dimetil sulfoxido

DTT Ditiotreitol

EDTA Ácido etilendiaminotetraacético

EGF Factor de crecimiento epidérmico
EP Epitelio pigmentario

HIS Hibridación in situ

HMG Grupo de alta movilidad

IGF-I factor de crecimiento insulínico I

MLE Membrana limitante externa

MLI Membrana limitante interna

MTT 3-(4,5-dimetiltiazol-2-ilo)-2,5-difeniltetrazol

NBT Azul de nitrotetrazolio

PCNA Antígeno nuclear de proliferación celular

PCR Reacción en cadena de la polimerasa

PDGF Factor de crecimiento derivado de plaquetas

Ptc Patched-Receptor de Shh

SDS Dodecil sulfato de sodio

SF Segmentos de los fotorreceptores

SHH Sonic hedgehog

SNC Sistema Nervioso Central

TBS Tris tamponado salino

TBST Tris tamponado salino con Tween-20

TEMED N,N,N',N'-tetrametiletilendiamina

TGGS Solución tris glicina glicerol

ZMC Zona marginal ciliar

ZPG Zona periférica germinal 
Índice general 
Capítulo 1

Introducción 
1. Introducción 


\subsection{La retina de teleósteos}

El ojo es el órgano encargado de la visión (Fig. 1.1). Las capas externas del ojo son la esclera y la coroides por la parte posterior, y la córnea por la parte delantera. Dentro del globo ocular se diferencian dos cámaras: la cámara anterior, que contiene el humor acuoso, y la cámara posterior, con el humor vítreo. Estas dos cámaras están separadas por el cristalino y el iris.

La retina es la parte más interna del globo ocular. Se origina a partir de una evaginación del prosencéfalo y, por tanto, forma parte del Sistema Nervioso Central (SNC). Sus funciones son las de recibir y realizar un primer procesamiento de la información visual pa-

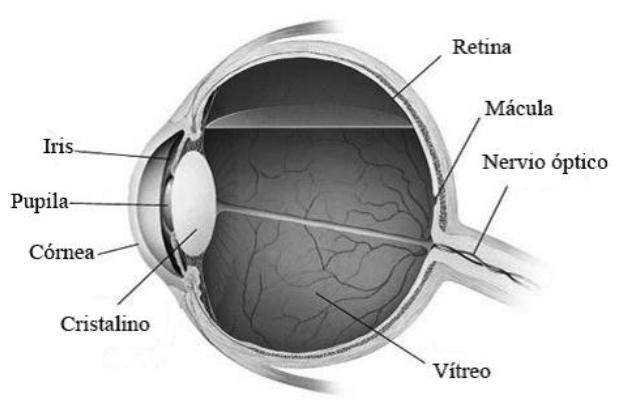
ra luego enviarla a diversos centros encefálicos superiores por medio del nervio óptico.

Figura 1.1: Esquema del globo ocular humano (Kolb et al., 2000)

La retina contiene células gliales (astrocitos, microglía, oligodendrocitos y células de Müller), fotorreceptores (conos y bastones), varios tipos de interneuronas (células bipolares, horizontales, interplexiformes y amacrinas), y un solo tipo de células de proyección, las células ganglionares.

La información visual se genera en el segmento externo de los fotorreceptores tras producirse la fotorrecepción, teniendo que atravesar la luz todo el espesor de la retina. A partir de aquí la información sigue una vía vertical de transmisión, pasando a las células bipolares y de ahí a las células ganglionares. Antes de que la información sea enviada a centros superiores, sufre una modulación por parte de la vía horizontal, en la que intervienen las células horizontales, las interplexiformes y las amacrinas.

Los tipos celulares de la retina se encuentran organizados en capas nucleares, donde se localizan los somas, que alternan con capas plexiformes constituidas por sus procesos y conexiones. Se distinguen 10 estratos diferentes (Fig. 1.2), que de la parte escleral a la vitreal son: 


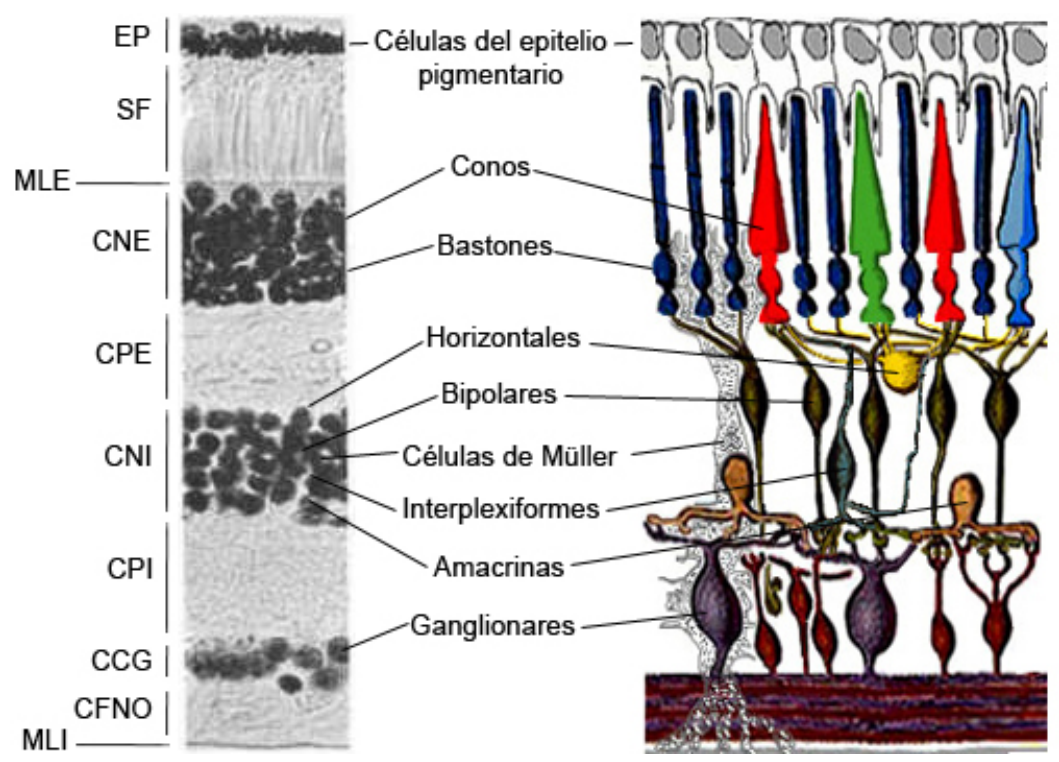

Figura 1.2: Esquema de la retina donde se indica la ubicación de las capas y los distintos tipos celulares

- Epitelio pigmentario (EP) que constituye la barrera hematorretiniana.

- Capa de los segmentos de los fotorreceptores (SF), formada por los segmentos internos y externos de los conos y los bastones.

- Membrana limitante externa (MLE), formada por las uniones entre los fotorreceptores y los pies esclerales de las células de Müller.

- Capa nuclear externa (CNE), donde se sitúan los somas de los conos y los bastones.

- Capa plexiforme externa (CPE), donde se localizan las sinapsis entre los fotorreceptores y las interneuronas.

- Capa nuclear interna (CNI), constituida por los somas de las interneuronas y de las células de Müller.

- Capa plexiforme interna (CPI), formada por los procesos de las células bipolares, interplexiformes, amacrinas y ganglionares.

- Capa de las células ganglionares (CCG), compuesta por los somas de las células ganglionares. 
- Capa de las fibras del nervio óptico (CFNO), formada por los axones de las células ganglionares.

- Membrana limitante interna (MLI), constituida por los pies vitreales de las células de Müller.

La estructura de la retina es común a todos los vertebrados, pero hay grandes diferencias en cuanto a las conexiones que se establecen entre las células, su distribución y los neurotransmisores que utilizan. Estas propiedades son características de grandes grupos de vertebrados, o adaptaciones a distintos nichos ecológicos (Wagner, 1990). En teleósteos es más difícil que en otros grupos el mostrar un modelo único, ya que esta familia cuenta con una gran variedad de especies que viven en hábitats muy diversos.

\subsubsection{Células de la retina}

\section{Células del epitelio pigmentario}

Las células epiteliales que se sitúan entre la coroides y la retina neural forman una monocapa y poseen por lo general abundantes gránulos de melanina. Su lámina basal forma parte de la membrana de Bruch, la región más interna de la coroides. En su cara más apical poseen procesos alargados que se intercalan con los segmentos externos de los fotorreceptores (Wagner, 1990; Marc, 1998). Dichos procesos pueden llegar hasta la membrana limitante externa donde se interdigitan con microvellosidades de las células de Müller. Las funciones que realizan las células epiteliales son múltiples: regulan la concentración de agua e iones en el espacio subretinal, protegen contra radicales libres, y fagocitan los segmentos externos de los fotorreceptores permitiendo su continua renovación. Además, participan en el proceso de fototransducción ya que aportan el retinal, imprescindible para dicho proceso (Young y Bok, 1969). 


\section{Introducción}

\section{Fotorreceptores}

Son células que presentan una morfología muy característica. Su cuerpo celular es pequeño y se sitúa en la capa nuclear externa. De él parte un axón en dirección vitreal, que termina en la CPE donde contacta con células horizontales y bipolares. En dirección escleral los fotorreceptores poseen un proceso especializado que se divide en un segmento externo y en un segmento interno. El segmento externo contiene múltiples discos membranosos orientados de forma transversal en los que se insertan los pigmentos fotosensibles (Kolb et al., 2000). Estos discos sufren una renovación continua, sintetizándose en la parte basal y siendo fagocitados por el EP en la parte apical (Young, 1971).

En todos los grupos de vertebrados, los fotorreceptores se dividen según la morfología de su segmento externo, en dos tipos: los conos, con el segmento externo corto y de forma cónica, y los bastones, cuyo segmento es cilíndrico (Fig. 1.3 B y C). Todos los somas se encuentran en la CNE, aunque se distribuyen de manera específica. Los somas de los conos forman una monocapa en la región más próxima a la MLE, mientras que los bastones ocupan el resto de la capa

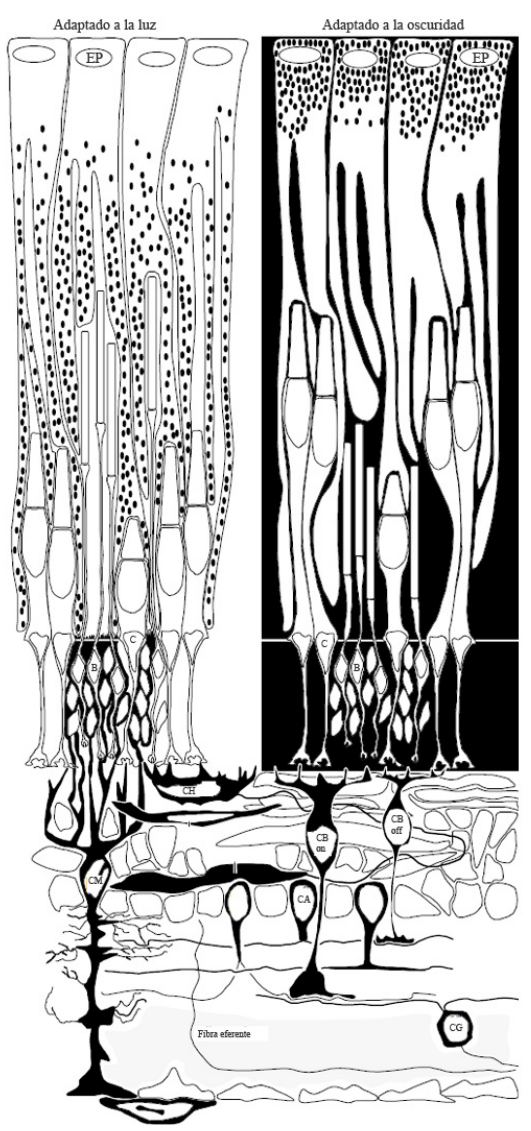

Figura 1.3: Esquema de los movimientos retinomotores en la adaptación a la luz y a la oscuridad. EP, epitelio pigmentario. $\mathrm{B}$, bastones. $\mathrm{C}$, conos. $\mathrm{CH}$, células horizontales. CB, células bipolares. CA, células amacrinas. CG, células ganglionares. CM, células de Müller. Adaptado de Marc (1998)

(Kolb et al., 2000).

La morfología de conos y bastones es diferente, y su función es también específica, constituyendo dos sistemas diferentes de recepción de la señal luminosa. Los bastones, cuyo fotopigmento es la rodopsina, son los responsables de la visión escotópica y son sensibles a la luz de muy baja intensidad. A partir de cierto nivel 
de iluminación, los bastones se saturan e intervienen los conos, capaces de registrar cambios rápidos en la intensidad lumínica, y con distintos pigmentos que permiten la visión en color (Kolb et al., 2000).

En teleósteos, anfibios y aves se producen contracciones y extensiones de los segmentos de los fotorreceptores que permiten la adaptación a cada uno de los tipos de visión (Douglas y Wagner, 1982; Burnside et al., 1993; Kolbinger et al., 1996). Dichos movimientos se denominan retinomotores y van acompañados de la migración de los gránulos de pigmento en el epitelio pigmentario. Así, en una situación de oscuridad, los gránulos de pigmento se sitúan en la parte basal del epitelio, los segmentos externos de los conos se alargan y los de los bastones se retraen (Hodel et al., 2006), justo al contrario de lo que ocurre en presencia de luz (Fig. 1.3).

La proporción de conos y bastones difiere mucho entre especies, aunque, por lo general, hay mayor cantidad de bastones que de conos. En muchas especies, los conos se sitúan en zonas especializadas para enfocar la imagen y conseguir una mayor agudeza visual. El caso más complejo es el de la fóvea de primates y aves raptoras, que se sitúa en la retina central. Carece de bastones y presenta depresión de todas las capas vitreales. En algunos peces hay también una fóvea que presenta gran densidad de todos los tipos neuronales, pero la depresión afecta únicamente a la CFNO. En otros peces no hay depresión y se denomina "área de alta densidad celular". Según sea el hábito alimentario de los peces, dichas áreas se sitúan en distintas partes de la retina (Wagner, 1990; Easter, 1992; Beaudet et al., 1997).

Los bastones forman un único grupo desde el punto de vista morfológico y funcional, a diferencia de los conos, que son de diferentes tipos según la opsina que posean. Así, la mayoría de los mamíferos poseen dos tipos de conos (rojos y azules). Los primates tienen un tercer tipo de conos, los conos verdes que permiten la visión tricromática (Kolb et al., 2000). Los reptiles y las aves poseen una visión tetracromática, por la presencia de un cono que es sensible a la luz ultravioleta. Los hábitats de los teleósteos son muy variados y hay muchos tipos de visión, desde la monocromática de los peces abisales hasta la tetracromática que poseen otros, al menos durante algún periodo de su vida (Nag y Bhattacharjee, 1989; Wagner, 1990; Beaudet et al., 1997; Marc, 1998; Hawryshyn et al., 2003). El pez cebra (Danio rerio) posee conos dobles formados por una fracción principal sensible al rojo (doble cono largo) y un miembro accesorio sensible al verde (doble cono corto). También 
hay conos simples largos, sensibles al color azul, y conos simples cortos sensibles a la luz ultravioleta (Branchek y Bremiller, 1984; Robinson et al., 1993; Li et al., 2009). Los bastones y los distintos tipos de conos no se distribuyen de forma aleatoria, sino que forman mosaicos tanto en mamíferos como en otros grupos de animales. En el pez cebra se organizan en filas de conos azules y ultravioletas alternadas con filas de conos rojos y verdes (Robinson et al., 1993).

Las prolongaciones vitreales de los conos son de forma triangular y se denominan pedículos, mientras que las de los bastones son redondeadas y se denominan esférulas. En esas regiones es donde se establecen las sinapsis con otros tipos celulares. En los pedículos de los conos hay unas 30 sinapsis, pero sólo son dos en el caso de los bastones (Ahnelt et al., 1990). A nivel de los pedículos se forman unas estructuras conocidas como tríadas, compuestas por dos procesos laterales correspondientes a células horizontales y un proceso central de una célula bipolar que se alinea con el cono. En las esférulas de los bastones se producen sinapsis con un elemento lateral procedente de una célula horizontal y un elemento central de la célula bipolar de bastón, denominándose a todo el conjunto como díada (Kolb, 1979; Collin et al., 1996).

\section{Interneuronas}

Células horizontales. Son células de gran tamaño con los núcleos dispuestos horizontalmente en una sola capa en la parte más escleral de la CNI y expanden sus dendritas por toda la CPE. En teleósteos se han descrito cuatro tipos de células horizontales: tres tipos de células horizontales de conos y un tipo de célula horizontal que contacta con bastones (Song et al., 2008; Li et al., 2009). El campo receptivo de estas células está aumentado por la presencia de uniones gap entre células horizontales de un mismo tipo (Teranishi et al., 1983; Wolburg y Kurz-Isler, 1985).

Las células horizontales son neuronas inhibitorias que reciben señales de los fotorreceptores y modulan la información que pasa de las células fotorreceptoras a las células bipolares, aunque realizan también sinapsis con células interplexiformes (Marc y Liu, 1984; Marshak y Dowling, 1987). Son las responsables de que la respuesta esté codificada para el color y de que el campo receptivo de la célula bipolar posea una periferia antagonista a su centro; es decir, que si el centro es OFF (de 
respuesta a la oscuridad), la periferia es ON (de respuesta a la luz).

Células bipolares. El soma de estas células se sitúa en la región media de la CNI desde él parten procesos celulares en dos direcciones opuestas. Las dendritas se dirigen hacia la CPE donde realizan sinapsis con los fotorreceptores, las células horizontales y las células interplexiformes. El axón se dirige hacia la CPI, donde se ramifica y hace contacto con células ganglionares y amacrinas.

Las células bipolares transmiten la información directamente desde los fotorreceptores a las células ganglionares, creando las vías de respuesta ON y OFF, de respuesta a la luz y a la oscuridad respectivamente. Esta separación de las vías se produce gracias a la presencia de distintos receptores para el glutamato (neurotransmisor liberado por los fotorreceptores) en las células bipolares, que provocan una hiperpolarización en las células ON y una despolarización en las células OFF (Werblin y Dowling, 1969). Estas diferencias fisiológicas tienen una cierta correspondencia morfológica, ya que las células bipolares ON presentan los terminales sinápticos en la mitad vitreal de la CPI mientras que las bipolares OFF presentan sus terminales en la parte escleral de la misma (Famiglietti y Kolb, 1976; Wu et al., 2000).

La clasificación de las células bipolares se hace también según el tipo de fotorreceptor con el que contactan y con el tamaño del campo dendrítico. En los ciprínidos se han descrito 12 clases distintas de células bipolares de cono y 5 clases de células bipolares mixtas, de cono y bastón (Marc y Cameron, 2001; Connaughton et al., 2004). Los últimos estudios en el pez cebra, que combinan la clasificación del tipo de fotorreceptor con el que contactan, el tamaño del árbol dendrítico y si son células ON u OFF, describen hasta 33 clases distintas de células bipolares (Li et al., 2012).

Células interplexiformes. Las células interplexiformes tienen el soma en la CNI y poseen varias prolongaciones muy ramificadas que forman plexos en las dos capas plexiformes. Reciben aferencias sinápticas desde la CPI y envían eferencias hacia la CPE. Constituyen una vía centrífuga del flujo de información, enviándola desde las células amacrinas a las células horizontales y bipolares (Dowling y Ehinger, 1978; Marshak y Dowling, 1987). Además, las celulas interplexiformes se relacionan con la regulación de los movimientos retinomotores (Wagner y Wulle, 1992; Van Haesen- 


\section{Introducción}

donck et al., 1993) y reciben aferencias del nervio olfato-retinal (o terminal) (Stell et al., 1984; Zucker y Dowling, 1987; Uchiyama, 1990).

En el carpín se han descrito dos tipos de células interplexiformes, según el neurotransmisor que utilizan: las dopaminérgicas y las glicinérgicas. Las dopaminérgicas tienen su soma a la altura de las células amacrinas, sus dendritas descienden, se estratifican en la CPI y envían ramificaciones que ascienden a la CPE. El soma de las células interplexiformes glicinérgicas se encuentra a la altura de las células bipolares, sus dendritas primarias ascienden hasta la CPE, desde allí envían muchos procesos a la CPI (Kalloniatis y Marc, 1990; Wagner, 1990).

Células amacrinas. El soma de las células amacrinas se sitúa en la zona más vitreal de la CNI. Hay unas células amacrinas que se denominan desplazadas porque tienen el soma en la CCG; estas suponen un tercio de las células de la CCG (Hughes y Wieniawa-Narkiewicz, 1980). Se denominaron así debido a la ausencia de axón y sus dendritas se extienden por la CPI.

Morfológicamente son las células más diversificadas de la retina de vertebrados y, además, pueden contener distintos neurotransmisores o neuromoduladores. Se han elaborado múltiples clasificaciones de las células amacrinas en tipos y subtipos, que varían ampliamente de una especie a otra.

En teleósteos se distinguen cuatro grupos de células amacrinas según su función: de respuesta $\mathrm{ON}$ (que reciben aferencias de las bipolares ON), de respuesta OFF (contactan con las bipolares $\mathrm{OFF}$ ), de respuesta transitoria (que responden al inicio y al final del estímulo luminoso) y de respuesta codificada para el color (Djamgoz et al., 1990, 2001). Así se modula la información que llega a las células ganglionares.

\section{Células ganglionares}

Las células ganglionares son las únicas células de proyección de la retina. Su función es recoger la información visual procedente tanto de la vía vertical (de fotorreceptor a célula bipolar y de ésta a la célula ganglionar), como de la vía horizontal (de fotorreceptor a células horizontales, bipolares, amacrinas y ganglionares) y enviarla a centros encefálicos. 
Su soma es muy voluminoso y se sitúa en la CCG, aunque hay también células ganglionares desplazadas en la CNI (Hayes y Holden, 1983; Hitchcock y Easter, 1986). Sus dendritas hacen contacto en la CPI con las proyecciones de las células amacrinas y bipolares, manteniendo la segregación de las vías ON y OFF. Sus axones parten en dirección vitreal y discurren paralelamente a la superficie retiniana formando la CFNO. Al alcanzar la papila óptica, situada aproximadamente en el centro de la retina, el conjunto de axones atraviesa todas las capas de la retina para salir del globo ocular formando el nervio óptico. La siguiente estación de relevo de la información visual es el núcleo geniculado lateral del tálamo en mamíferos, y el techo óptico en el caso de los peces (Stuermer, 1988; Burril y Easter, 1994).

Se han descrito más de 20 tipos de células ganglionares según el tamaño del soma y la forma de las dendritas, aunque el $50 \%$ son de dos tipos: las M (o grandes) y las P (o pequeñas) (Boycott y Wäsle, 1974; Leventhal et al., 1981).

\section{Células gliales}

Células de Müller. Las células de Müller (Fig. 1.4) son las células gliales más abundantes en la retina (Turner y Cepko, 1987). Fueron descritas en 1851 por Müller y pertenecen a un grupo de astrocitos denominado como glía radial, no sólo por su morfología especializada, sino también por las funciones que realizan en la retina.

Su soma es poligonal y alargado y se sitúa en la parte central o vitreal de la CNI. Tienen dos prolongaciones que se extienden en direcciones opuestas y cubren casi todo el espesor de la retina, formando la MLE en la región escleral y la MLI en la región vitreal. En la MLE las prolon-

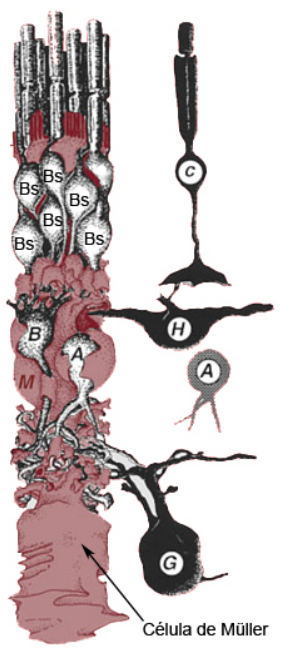
gaciones de las células de Müller contactan con

Figura 1.4: Esquema de una célula de Müller rodeando a las células de la retina (Kolb et al., 2000)

los fotorreceptores y con otras células de Müller, y emiten una serie de microvellosidades hacia el espacio subretinal (Reichenbach y Robinson, 1995). Los procesos 
que van hacia el vítreo contactan con otras células de Müller y forman una lámina basal, la MLI, que constituye una barrera entre la retina y la lámina conjuntiva subyacente. Las abundantes ramificaciones de los procesos de las celulas de Müller envuelven los somas, las dendritas y las estructuras sinápticas de todas las neuronas retinianas. Además, organizan en haces los axones de las neuronas ganglionares de la CFNO (Reichenbach y Wohlrab, 1986; Reichenbach y Robinson, 1995).

Las funciones que realizan las células de Müller son múltiples y fundamentales en el procesamiento de la información visual. Sirven de soporte y constituyen el principal reservorio de glucógeno de la retina, sosteniendo el metabolismo energético de las neuronas; acumulan glutation reducido protegiendo así a las neuronas de los radicales libres; participan en la formación de la barrera hematorretiniana; controlan el microambiente neuronal regulando el pH y la concentración de iones potasio; intervienen en la fagocitosis; retiran y reciclan rápidamente el exceso de neurotransmisores de los espacios presinápticos, e incluso, en el pollo, reciclan el retinal de los fotopigmentos (Newman y Reichenbach, 1996; Matsui et al., 1999; Bringmann et al., 2000).

Astrocitos. Los astrocitos son células con un soma aplanado y con procesos radiales. Se localizan casi exclusivamente en la CFNO, aunque en el mono se han descrito también en la CCG (Bussow, 1980; Distler et al., 1993). Su morfología es variable según su localización: pasan de ser alargados en la retina central, a estrellados en la retina más periférica (Schnitzer, 1988).

La función de los astrocitos en la retina está relacionada con el sistema vascular, pues en el desarrollo inducen y guían el crecimiento de los vasos en la misma (Zhang et al., 1999; Dorrell et al., 2002; Gariano, 2003). La función de los astrocitos en la retina avascular de teleósteos es la organización axónica en la cabeza del nervio óptico, interviniendo en los procesos de crecimiento, degeneración y regeneración axonal (Lillo et al., 1998; Jimeno, 2001; Clemente et al., 2008; Parrilla et al., 2009).

Oligodendrocitos. La función característica de los oligodendrocitos es la mielinización de los axones neuronales. En la retina de mamíferos, a excepción de los conejos, no hay ni oligodendrocitos ni axones mielinizados. Los conejos tienen axones mielinizados pertenecientes a células ganglionares de unas zonas específicas de 
la retina (Ehinger et al., 1994; Morcos y Chang-Ling, 1997). En teleósteos hay axones mielinizados, y por tanto, oligodendrocitos en la CFNO (Wolburg, 1980; Lillo et al., 1998). Se corresponden tanto con fibras retinópetas procedentes del núcleo olfacto-retinal (Uchiyama, 1990), como con fibras retinófugas (Lillo et al., 1998). En el carpín se ha propuesto que los axones no mielinizados, que son más superficiales, se corresponden con las células ganglionares jóvenes y los mielinizados con las células ganglionares más antiguas (Easter et al., 1984).

Microglía. La localización de las células microgliales en la retina es muy variable en los distintos grupos de vertebrados. En teleósteos se distribuyen principalmente en las capas plexiformes, en la CFNO, y en menor medida en las capas nucleares. $\mathrm{Su}$ morfología es por lo general de tipo ramificado, con un cuerpo celular pequeño y unos procesos irregulares y cortos, aunque también se puede encontrar microglía ameboide en la periferia de la retina y en la superficie vitreal asociada a los vasos sanguíneos (Velasco et al., 1995; Jimeno et al., 1999; Salvador-Silva et al., 2000; Lillo et al., 2001).

La microglía manifiesta su función principalmente en condiciones patológicas. Ante cualquier daño o lesión se activa, transformándose en microglía reactiva que prolifera, adquiere actividad fagocítica y expresa moléculas propias de macrófagos. Además, estas células modulan la respuesta inmune en todo el Sistema Nervioso y producen tanto sustancias neurotóxicas como factores tróficos (Moore y Thanos, 1996; Stoll y Jander, 1999; Chen et al., 2002). 


\subsection{Formación de la retina}

\subsubsection{Retinogénesis}

El desarrollo del ojo en los vertebrados comienza con un proceso de morfogénesis en el cual se produce una especificación regional de varias estructuras, seguido de la adquisición del destino y función celular (Pei y Rhodin, 1970).

Al final de la neurulación se produce una expansión bilateral del prosencéfalo, que se extiende hacia el ectodermo superficial formando la vesícula óptica, a la vez que la región medial se estrecha dando lugar al pedúnculo óptico. En ratón comienza en la fase embrionaria de E8,5 y en pez cebra alrededor de las 11,5 horas postfecundación (hpf). Las vesículas ópticas se invaginan en su superficie lateral formando la copa óptica. A la vez se constituye la placoda del cristalino a partir de un engrosamiento del ectodermo superficial. La capa más externa de la copa óptica se adelgaza y da lugar al epitelio pigmentario y la más interna prolifera transformándose en la retina neuronal (Fig. 1.5) (Geneser, 1993; Chow y Lang, 2001). Las células del margen forman el epitelio biestratificado del cuerpo ciliar y el iris. Otras estructuras del ojo, como son los estromas del iris, el cuerpo ciliar y la córnea se originan a partir de un cúmulo de células, entre la placoda del cristalino y el ectodermo, procedentes del mesodermo y la cresta neural (Johnston et al., 1979; Thut et al., 2001; Soules y Link, 2005).

Desde que aparece el primordio óptico, se observa un gran número de células en mitosis en el mismo, mientras que durante la formación de la copa óptica hay un aumento en la duración del ciclo celular, lo que conlleva una disminución del número de figuras mitóticas (Li et al., 2000). Hacia el final de la morfogénesis, la proliferación desaparece completamente en el estrato externo de la copa óptica, y las células empiezan a cargarse de melanina. Sin embargo, en la retina neural la división celular se acelera considerablemente.

En la retina del pez cebra la neurogénesis comienza hacia las 24 hpf (Schmitt y Dowling, 1994). En un primer momento, las células de las vesículas ópticas son multipotentes y expresan marcadores de células altamente indiferenciadas, tales como rx1, otx2, pax6 y six3 (Zuber et al., 2003). La diferenciación de las células retinia- 

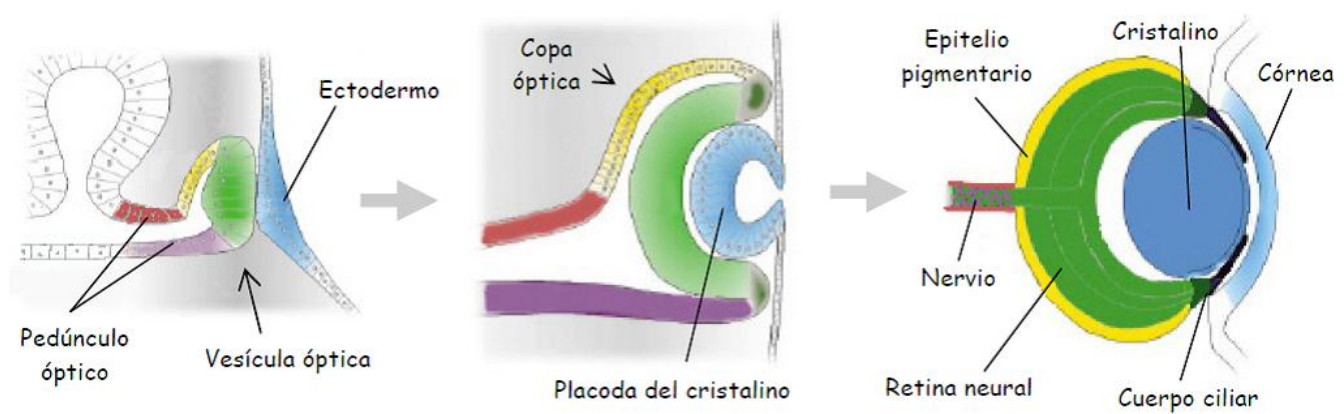

Figura 1.5: Esquema de la morfogénesis del ojo. Modificado de Chow y Lang, 2001

nas es un proceso altamente organizado, en el que las células ganglionares son las primeras en diferenciarse, entre las 28 y las 32 hpf. Estas células expresan un factor de transcripción llamado Athonal5 (Ath5), que constituye el primer marcador de diferenciación de la retina. A partir de las 48 hpf aproximadamente, se produce la diferenciación de las células amacrinas, bipolares, horizontales y de las células de Müller, seguido por la diferenciación de los fotorreceptores. Además de una secuencia temporal, se puede observar también una secuencia espacial en la neurogénesis de la retina. Así, la primera zona en diferenciarse es la ventro-nasal y después se extiende hacia la zona ventro-temporal (revisado en Morris y Fadool (2005)).

\subsubsection{Neurogénesis en la retina adulta de teleósteos}

La neurogénesis en animales adultos es un proceso que ha sido demostrado en todas las especies de vertebrados estudiados hasta ahora, aunque con grandes diferencias entre ellas. En mamíferos se han descrito tres regiones encefálicas donde se generan neuronas durante toda la vida del animal: el epitelio olfatorio, la zona subependimal de los ventrículos laterales (desde donde las nuevas neuronas migran, vía la corriente migratoria rostral, hasta el bulbo olfatorio) y el giro dentado del hipocampo (Altman, 1962; Alvarez-Buylla y García-Verdugo, 2002; Calof et al., 2002; Taupin y Gage, 2002).

En otros vertebrados como anfibios (Bernocchi et al., 1990; Chetverukhin y Polenov, 1993), reptiles (Font et al., 2001) y teleósteos (Zupanc, 1999; Ekström et al., 2001) hay varias zonas de proliferación diferentes. De hecho, se ha demostrado que la tasa de proliferación en el cerebro adulto de teleósteos es uno o dos órdenes de 


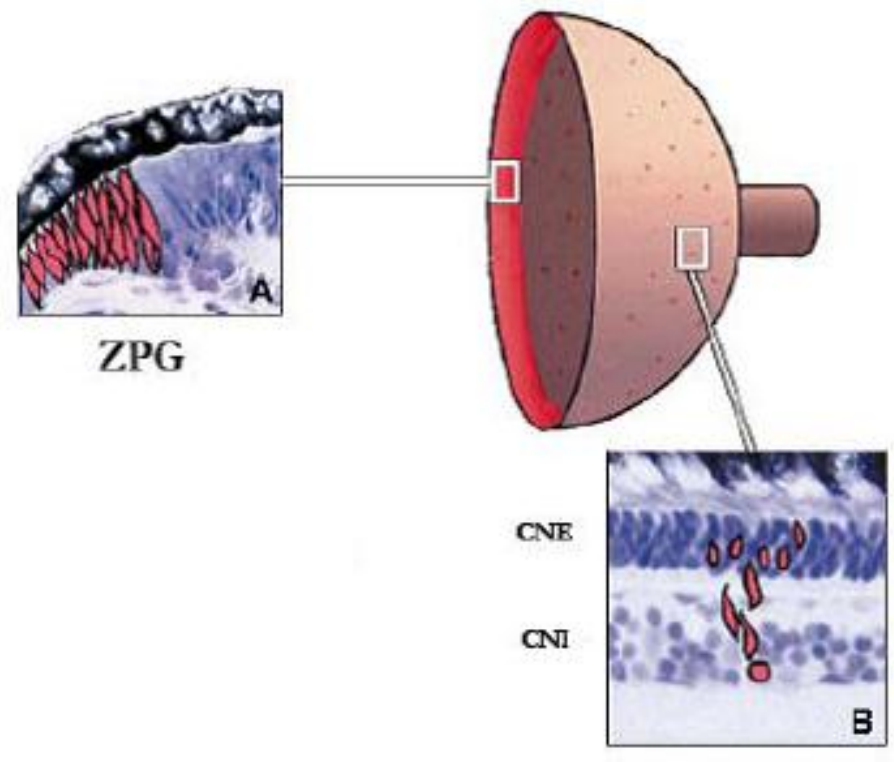

Figura 1.6: Localización de las dos poblaciones de progenitores en la retina de teleósteos, la zona periférica germinal $(\mathrm{A})$ y los progenitores de bastón en la retina central (B). Modificado de Otteson et al. (2001)

magnitud superior a la del cerebro adulto de mamíferos (Zupanc, 2006). Las zonas de proliferación en teleósteos incluyen el bulbo olfatorio, las áreas telencefálicas, el techo óptico, el cerebelo y el tronco del encéfalo. Se podría generalizar que las zonas de proliferación se localizan en la zona ventricular o en regiones que corresponden a porciones ventriculares embrionarias (Zupanc, 1999; Ekström et al., 2001). La formación de nuevas células no sólo permite el crecimiento continuo del Sistema Nervioso a lo largo de toda la vida del animal, sino que posibilita también la regeneración tras una lesión (Easter, 1983; Raymond y Hitchcock, 2000). Una de las zonas proliferativas del Sistema Nervioso Central más estudiadas en teleósteos ha sido el sistema visual.

Müller, en 1952, realizó el primer estudio sobre el crecimiento postembrionario de la retina de peces y demostró, junto con otros investigadores posteriores, que desde la eclosión hasta los estadios adultos, hay un incremento en el número total de neuronas retinianas y de fibras de la CFNO y del nervio óptico (Müller, 1952; Lyall, 1957; Johns, 1977; Kock, 1982), además de aumentar el volumen de la misma.

El aumento del número de neuronas es debido a la presencia de un anillo de células proliferativas situado en la periferia de la retina, denominado zona periférica germinal o ZPG (Müller, 1952; Johns, 1977; Meyer, 1978) (Fig. 1.6 A).

El crecimiento en volumen se produce principalmente por la expansión del tejido maduro debido a un aumento del número de procesos celulares. Esta expansión trae 
consigo una disminución de la densidad celular (Lyall, 1957; Johns y Easter, 1977; Macy y Easter, 1981; Kock, 1982).

Los bastones son las únicas células cuya densidad celular no disminuye, ya que en la retina madura hay un grupo de células progenitoras que dan lugar a bastones de manera constante (Fig. 1.6 B).

\section{Zona periférica germinal (ZPG)}

La ZPG está formada por un conjunto de células proliferativas, con morfología neuroepitelial típica (Raymond y Rivlin, 1987) remanentes de la copa óptica, que forman un círculo contínuo en el margen de la retina (Müller, 1952; Grün, 1975; Johns, 1977). En su extremo central se continúa con la retina neural y por su extremo periférico se continúa con el estrato no pigmentado del epitelio ciliar (Olson et al., 1999).

Además de su capacidad de autorrenovación, las células de la ZPG tienen la capacidad de generar todos los tipos celulares de la retina durante toda la vida del animal (Müller, 1952; Otteson y Hitchcock, 2003). Las células que se diferencian forman anillos concéntricos de nueva retina, de modo que las nuevas oleadas quedan en zonas progresivamente más periféricas (Johns, 1977; Scholes, 1979; Easter, 1992). Este crecimiento anular crea un orden espacial muy concreto, originándose entre la ZPG y la retina madura una zona de transición donde la laminación no está todavía establecida y las células están aún diferenciándose (Olson et al., 1999; Lillo et al., 2001)(Fig. 1.7). Las distintas capas se van diferenciando progresivamente, siendo la primera en diferenciarse la CCG seguida de la CNI y la CNE (Olson et al., 1999). Las únicas células que no se diferencian en la zona de transición ni en la retina adyacente son los bastones ya que, como hemos señalado anteriormente, hay una población de progenitores en la retina madura que da lugar a dichas células (Johns, 1982; Raymond, 1985).

\section{Linaje de bastones}

La generación de nuevos bastones en teleósteos se caracteriza porque ocurre en regiones maduras de la retina y se encuentra retrasada con respecto a la generación 


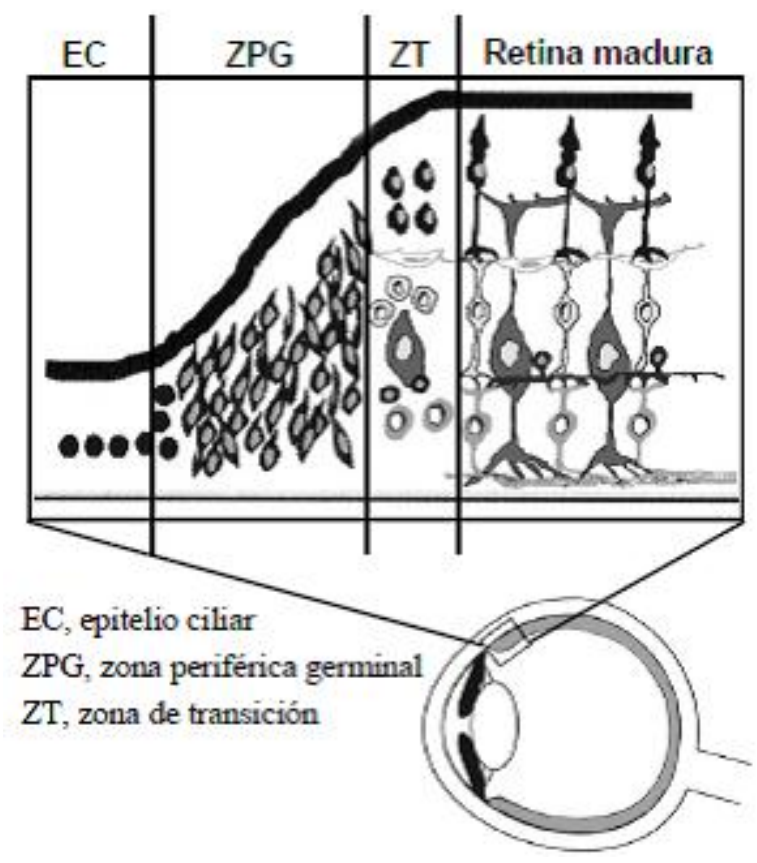

Figura 1.7: Esquema de la retina periférica de teleósteos, donde se muestran los pasos de las células hasta diferenciarse. Modificado de Hitchcock et al. (2004)

del resto de las células retinianas (Raymond, 1991). De hecho, en el pez cebra, tras la eclosión, la CNE consiste en una única capa de conos que se están diferenciando, y no es hasta el final del periodo larvario cuando empiezan a formarse los bastones (Johns, 1982; Branchek y Bremiller, 1984; Raymond, 1991). Incluso en estadios adultos, buena parte de la retina periférica carece de bastones (Johns, 1982; Lillo et al., 2001).

La procedencia de las células progenitoras de bastones ha sido intensamente debatida en los últimos años, ya que aunque tradicionalmente se creía que provenían únicamente de la ZPG (Otteson et al., 2001; Otteson y Hitchcock, 2003), recientemente se ha demostrado que las células de Müller también participan en el proceso (Bernardos et al., 2007; Kassen et al., 2008; Stenkamp, 2011). En la retina recién formada queda un remanente de células inmaduras, que se mantienen indiferenciadas hasta que se diferencian en bastones (Fig. 1.8 A). Por otro lado, se ha propuesto que las células de Müller tienen la capacidad de desdiferenciarse y generar nuevas células progenitoras (Fig. 1.8 B).

En una retina intacta, las células progenitoras de bastón dan lugar únicamente a bastones, pero tienen la capacidad de generar cualquier tipo retiniano frente a una 
A

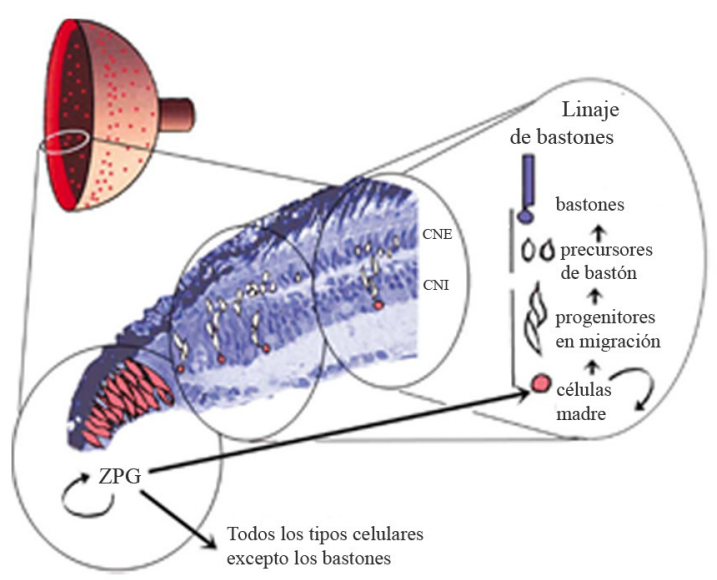

B

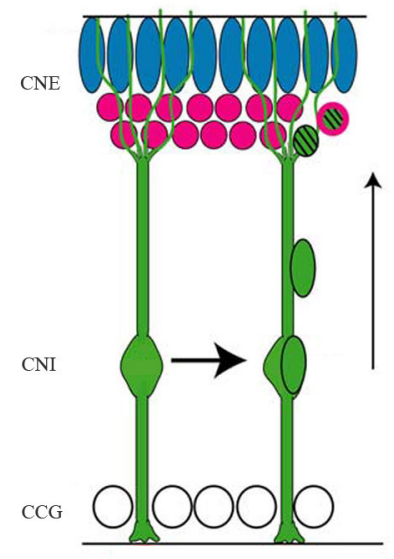

Figura 1.8: Esquema que muestra el origen de los progenitores de bastón, a partir de la zona periférica germinal (A, modificado de Otteson et al. (2001)) y a partir de la desdiferenciación de las células de Müller (B, modificado de Bernardos et al. (2007))

lesión (Morris et al., 2008).

Los progenitores de bastón se han estudiado profundamente en el carpín (Johns, 1982; Raymond, 1985; Cid et al., 2002; Sánchez-González, 2009), pero también en otras especies de teleósteos como la trucha (Julian et al., 1998), la tenca y el pez cebra (Cid et al., 2002; Raymond et al., 2006). Estos estudios indican que los progenitores de bastón pueden ser de tres tipos según su capacidad proliferativa, su localización y la morfología de su núcleo.

Progenitores retinianos de la CNI. Son células prácticamente quiescentes, redondeadas e indiferenciadas (Otteson et al., 2001; Otteson y Hitchcock, 2003). Se localizan en la región más vitreal de la CNI y expresan Pax6 (Otteson et al., 2001; Otteson y Hitchcock, 2003; Sánchez-González, 2009) y Notch1 (Sánchez-González, 2009). Estas son las únicas células que son lo suficientemente inmaduras como para producir progenitores que se diferencien a otros tipos celulares en caso de lesión (Morris et al., 2008), a excepción de las células de Müller que tienen capacidad de desdiferenciación (Bernardos et al., 2007). 
Progenitores en migración. Cuando los progenitores de la CNI se dividen, además de renovarse generan otro tipo de células que migran a través de la CNI y la CPE hasta la CNE (Otteson y Hitchcock, 2003). Dichas células se disponen aisladas o en pequeños grupos de tres o cuatro células asociadas a las células de Müller (Raymond y Rivlin, 1987). Su morfología es alargada, con dos procesos vitreales que nunca se extienden fuera de la CNI y un proceso escleral que puede penetrar en la CPE (Raymond y Rivlin, 1987).

Precursores de bastón. Una vez en la CNE, los progenitores se convierten en el tercer tipo de células, los precursores de bastón (Julian et al., 1998). Se localizan en posición vitreal dentro de la CNE y poseen uno o dos procesos esclerales que no sobrepasan la MLE, pero nunca presentan procesos vitreales (Raymond y Rivlin, 1987). Se dividen muy rápidamente y su número es más abundante que el de los otros dos tipos, por lo que fueron los primeros progenitores de bastón en ser descritos (Johns, 1982; Raymond, 1985).

\section{Progenitores en la retina de otros vertebrados}

Podemos afirmar, en general, que la neurogénesis en el Sistema Nervioso Central adulto se ha ido reduciendo progresivamente en el transcurso de la evolución de los vertebrados, no sólo en la capacidad de proliferación, sino también en la capacidad para formar ciertos tipos celulares. Lo mismo ocurre en la retina, ya que mientras los progenitores de bastón son exclusivos de peces, se han descrito zonas proliferativas similares a la ZPG en otros grupos de vertebrados (Fig. 1.9).

Anfibios. Los anfibios, al igual que los teleósteos, tienen una ZPG en la retina que en este grupo se denomina zona marginal ciliar o ZMC (Hollyfield, 1968; Straznicky y Gaze, 1971; Umino y Saito, 2002). Ha sido muy estudiada sobre todo en Xenopus, y en algunos aspectos es mejor conocida que la ZPG de teleósteos. Se ha descrito que la ZMC se divide en cuatro regiones, según el grado de diferenciación y la capacidad de proliferación que posean las células (Perron et al., 1998). En la región más periférica se sitúan las células multipotentes, con un ciclo celular lento, seguidas por retinoblastos multipotentes con una división más activa; a continuación se disponen 
los retinoblastos que se comprometen hacia tipos celulares concretos, y en la zona más central se encuentran las células que comienzan a diferenciarse (Perron et al., 1998; Perron y Harris, 2000; Hitchcock et al., 2004).

Aves y mamíferos. La retina de aves y mamíferos sigue creciendo tras la eclosión o el nacimiento, aunque por un periodo limitado (Perron y Harris, 2000; Kubota et al., 2002). Hasta hace relativamente poco se creía que era debido exclusivamente a una expansión del tejido; sin embargo, estudios más recientes apuntan que hay proliferación celular. En algunas especies de aves se ha descrito la presencia de una zona proliferativa similar a la ZPG de teleósteos y a la ZMC de anfibios, que permanece activa hasta los dos meses tras la eclosión (Kubota et al., 2002). Las células de esa región, a diferencia de los teleósteos o los anfibios, tienen una potencialidad restringida para dar lugar a ciertos tipos celulares (Fischer y Reh, 2000). En ratones y ratas la actividad mitótica tras la retinogénesis se reduce a células del epitelio ciliar (Ahmad et al., 2000; Tropepe et al., 2000; Kubota et al., 2002). Además, las células del estrato pigmentado del epitelio ciliar se comportan como células troncales in vitro aunque in vivo permanezcan quiescentes (Ahmad et al., 2000; Tropepe et al., 2000; Bhatia et al., 2009).

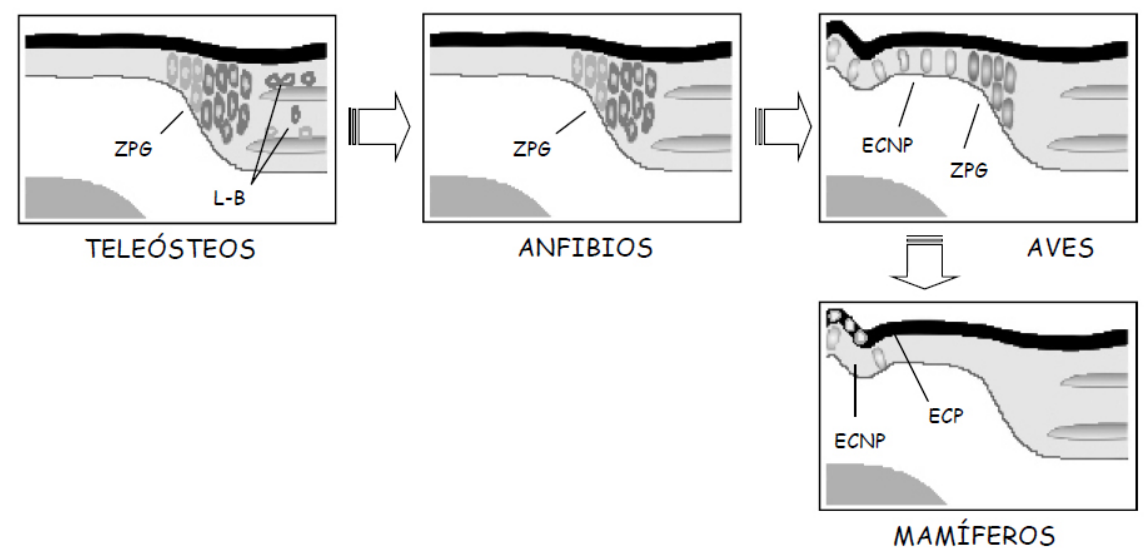

Figura 1.9: Localización de las poblaciones de progenitores neurales descritas en la retina adulta de distintos grupos de vertebrados. ZPG, zona periférica germinal; L-B, linaje de bastones; ECNP, epitelio ciliar no pigmentado; ECP, epitelio ciliar pigmentado. Amato et al. (2004b) 


\subsection{Enfermedades retinianas y terapia celular}

La degeneración de los fotorreceptores ocurre en determinadas enfermedades retinianas como la retinosis pigmentaria, la retinopatía diabética y la degeneración macular asociada a la edad.

La retinosis pigmentaria es un grupo heterogéneo de enfermedades retinianas hereditarias, y supone la más común de las enfermedades degenerativas de la retina a nivel mundial, con una incidencia de aproximadamente un caso por cada 3000 habitantes (Nájera et al., 1995; Hartong et al., 2006; Shintani et al., 2009). Hasta el momento se han descrito hasta 45 genes afectados, que explican únicamente el problema del $60 \%$ de los pacientes. La enfermedad se puede heredar de forma autosómica recesiva, autosómica dominante o bien ligada al cromosoma X (Hartong et al., 2006). La mayor parte de los genes implicados están relacionados con los bastones, que por tanto son los primeros en degenerar. La muerte de los bastones induce una muerte posterior de los conos (Hartong et al., 2006).

La retinopatía diabética es una de las complicaciones derivadas tanto de la diabetes tipo 1 como de la de tipo 2. Es la principal causa de ceguera entre los individuos en edad de trabajar de Estados Unidos. Aunque siempre se ha pensado que ocurre por un deterioro de los vasos sanguíneos que irrigan la retina, se ha descrito que hay muerte de las neuronas de la retina previamente a observar dicho deterioro (Seki et al., 2004; Arden et al., 2005; Gastinger et al., 2006; Kern y Barber, 2008). En el caso de los bastones puede deberse a hipoxia, que ocurre en la retina normal, pero aumenta en la retina enferma, ya que la irrigación sanguínea está alterada en pacientes diabéticos (Arden et al., 2005).

En Occidente, la principal causa de ceguera en las personas mayores de 65 años es la degeneración macular asociada a la edad (DMAE). Hay dos tipos de DMAE, la no exudativa o atrófica, caracterizada por la degeneración de los capilares, de la retina neurosensorial y del epitelio pigmentario, y la exudativa o neovascular. Esta enfermedad tiene un componente genético (Ting et al., 2009), pero hay varios factores ambientales que aumentan el riesgo de sufrirla, como el tabaquismo (Ni Dhubhghaill et al., 2010) o la infección por Chlamydia pneumoniae (Robman et al., 2005) entre otros. 
De las tres retinopatías aquí descritas, en la actualidad únicamente tiene tratamiento efectivo la DMAE exudativa. Una de las terapias más utilizadas para tratar dichas enfermedades han sido los trasplantes, y en ese sentido se han realizado trasplantes tanto con explantes de retinas intactas (Radtke et al., 2004) como con capas aisladas (Silverman y Hughes, 1989), ya sean de tejido adulto o embrionario. El grado de recuperación obtenido no está muy claro, ya que parece que sólo los trasplantes tienen un efecto neuroprotector retardando la degeneración de los fotorreceptores. Una desventaja en este tipo de terapia es que se requiere gran cantidad de tejido, lo que dificulta la posibilidad de realizar autotrasplantes en humanos.

Sin embargo, al descubrirse la presencia de células progenitoras en la retina adulta de mamíferos, se abre la posibilidad de analizar nuevas estrategias terapéuticas orientadas a reponer las células que se han perdido. Estos nuevos hallazgos han hecho que muchos investigadores se replanteen las terapias celulares utilizadas hasta el momento, ya que las células progenitoras permitirían realizar trasplantes mas precisos que repusieran específicamente los tipos celulares degenerados. Se ha descrito que el grado de diferenciación de las células a trasplantar es un factor determinante (MacLaren et al., 2006), ya que su integración en la retina degenerativa dependerá de su capacidad para migrar y diferenciarse a un tipo celular en concreto. Por ello, es muy importante conocer la potencialidad de las células progenitoras y qué factores son necesarios para obtener el grado de diferenciación óptimo para el trasplante. Este nuevo enfoque genera la necesidad de abordar la caracterización de los progenitores retinianos, ya que los datos obtenidos en los estudios in vivo son insuficientes a la hora de plantear nuevas terapias celulares. Todo ello ha conducido a que, además de su caracterización in vivo, los estudios in vitro se hayan convertido en una herramienta imprescindible para caracterizar los progenitores retinianos.

\subsection{Detección y caracterización de las células pro- genitoras}

El primer paso para la caracterización de las células progenitoras en secciones de tejido es su identificación mediante marcadores de proliferación celular. En la actualidad hay numerosos productos destinados a este fin: los nucleótidos marcados 
o los análogos de los nucleótidos (la timidina tritiada o la 5-bromo-2-desoxiuridina, entre otros), las proteínas implicadas en el ciclo celular como la PCNA (Proliferating Cell Nuclear Antigen) o la histona H3 fosforilada. La PCNA es un cofactor de la ADN polimerasa delta (Bravo et al., 1987; Prelich et al., 1987), que se expresa mayoritariamente en la fase S del ciclo celular (Bravo y Macdonald-Bravo, 1987; Negishi et al., 1990; Bolton et al., 1992). La fosforilación de la histona H3 en una serina del extremo N-terminal (Prigent y Dimitrov, 2003) está relacionada espacial y temporalmente con la condensación cromosómica: comienza en la fase G2 del ciclo celular y se mantiene en la fase M (Hendzel et al., 1997).

El marcador más utilizado en la actualidad para identificar células en proliferación es la 5-bromo-2-desoxiuridina o BrdU, que es un nucleótido sintético análogo a la timidina (Fig. 1.10). En su presencia, las células durante la replicación incorporan BrdU preferentemente en vez de timidina. De esta manera, la nueva hebra se puede detectar mediante una inmunohistoquímica con anticuerpos específicos contra BrdU. Se ha descrito que la tasa de incorporación de BrdU oscila entre un 99,8\% y un $100 \%$ en estudios in vitro (Bick y Davidson, 1974). La ventaja de la utilización de BrdU frente a

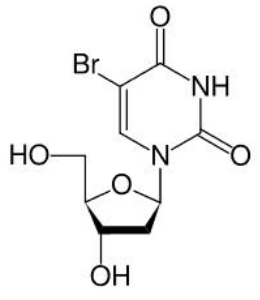

Figura 1.10: Estructura de la 5-bromo-2desoxiuridina PCNA o a histona H3 fosforilada es que marca todas las células que se han dividido desde la primera aplicación, mientras que los otros dos métodos marcan sólo las células que se encuentran en una fase determinada del ciclo celular.

Una vez detectadas las células progenitoras, el siguiente paso es su caracterización, estudiando la expresión de diferentes marcadores moleculares, bien marcadores de células indiferenciadas o marcadores relacionados con la diferenciación celular de las células de la retina.

\subsubsection{Prox1}

El gen Prox1 es un homólogo del gen prospero de Drosophila. Se ha detectado en varios grupos de vertebrados, sin encontrarse en ningún caso genes parálogos (Oliver et al., 1993; Tomarev et al., 1996; Glasgow y Tomarev, 1998). La proteína tiene en el extremo C-terminal una región conservada denominada prospero, que podría 
participar en la unión al ADN o a otras proteínas, además de un homeodominio (Bürglin, 1994; Tomarev et al., 1996).

Prox1 se expresa en varios tejidos durante el desarrollo y en estadios adultos: hepatocitos, epitelio del páncreas, endotelio linfático y en diversas estructuras del SNC y periférico (Oliver et al., 1993; Tomarev et al., 1996; Rodriguez-Niedenführ et al., 2001). Durante la retinogénesis Prox1 interviene en la diferenciación de las células horizontales y bipolares (Dyer et al., 2003; Cid et al., 2010). En la retina madura se encuentra en células horizontales, amacrinas y bipolares (Belecky-Adams et al., 1997; Dyer et al., 2003; Edqvist y Halböök, 2004; Cid et al., 2010). En carpín, la proteína Prox1 se expresa en la ZPG y en progenitores de bastón en migración (Sánchez-González, 2009; Cid et al., 2010), así como en células de Müller (Cid et al., 2010).

\subsubsection{Pax6}

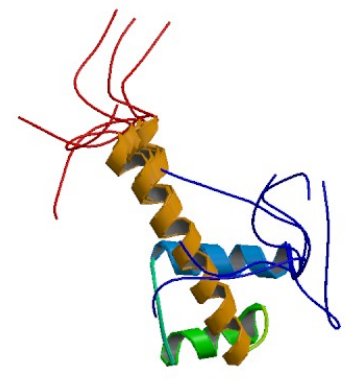

Figura 1.11: Estructura terciaria de Pax6
Los genes de la familia Pax (paired box) codifican factores de transcripción fundamentales para el desarrollo embrionario. Estos factores poseen un dominio de unión al ADN denominado paired, y algunos además pueden presentar otro dominio de unión, un homeodominio con estructura hélice-giro-hélice (Kissinger et al., 1990; Tremblay y Gruss, 1994). El gen Pax 6 (Fig. 1.11) presenta un alto grado de conservación en la evolución, con gran homología incluso entre vertebrados e invertebrados (Püschel et al., 1992; Del Rio-Tsonis et al., 1995; Hirsch y Harris, 1997). En peces se encuentra duplicado (pax6a, pax6b), aunque ambos cumplen una función similar al gen de mamíferos (Nornes et al., 1998). Se trata de un gen de 17 exones situado en el cromosoma 25 (Lakowski et al., 2007).

El gen Pax6 se considera clave en el desarrollo y formación del ojo, ya que mutaciones del mismo producen enfermedades en humanos como la aniridia o la anomalía de Peter (Prosser y van Heyningen, 1998; Hever et al., 2006), y su sobreexpresión en Drosophila y Xenopus induce la formación ectópica de ojos (Halder et al., 1995; 


\section{Introducción}

Chow et al., 1999). En individuos adultos se expresa en la CCG y en el estrato vitreal de la CNI (Krauss et al., 1991; Martin et al., 1992; Püschel et al., 1992; Hitchcock et al., 1996; Hirsch y Harris, 1997; Bhat et al., 1999; Kaneko et al., 1999; Strickler et al., 2001; Ziman et al., 2001), así como en células horizontales (Edqvist et al., 2006; Fischer et al., 2007). En teleósteos el gen se expresa también en los progenitores de la CNI (Otteson et al., 2001; Raymond et al., 2006; Sánchez-González, 2009), y en la ZPG (Hitchcock et al., 1996; Perron et al., 1998; Kaneko et al., 1999; Faillace et al., 2002; Sánchez-González, 2009).

\subsubsection{Sox 2}

La familia de los factores de transcripción Sox (de "caja de la región determinante sexual del cromosoma Y, SRY-box") está formada por 9 grupos de genes que codifican para proteínas que se unen a la hélice menor del $\mathrm{ADN}$, lo que provoca que el $\mathrm{ADN}$ se curve (Ferrari et al., 1992). Sox2 pertenece al grupo B1 (Bowles et al., 2000), está situado en el cromosoma 22 del pez cebra y al igual que la mayoría de los otros genes de la familia (Pevny y Lovell-Badge, 1997) carece de intrones. La proteína posee un grupo de alta movilidad (HMG, de sus siglas en inglés), que

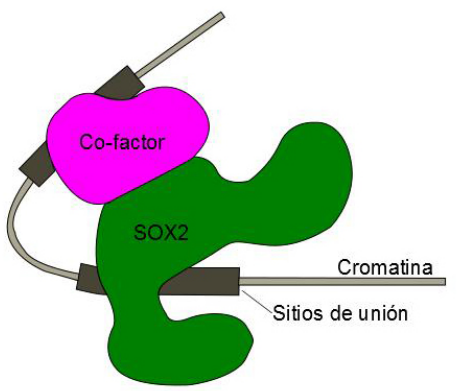

Figura 1.12: Modo de unión de Sox2 al ADN. Modificado de Wilson y Koopman (2002) es el encargado de interaccionar con el ADN (Kamachi et al., 1999; Wissmüller et al., 2006), aunque debido a su poca estabilidad, esta unión tiene que darse junto a otras proteínas (Scaffidi y Bianchi, 2001; Wilson y Koopman, 2002) (Fig. 1.12).

Sox2 se expresa en células troncales multipotentes del neuroepitelio embrionario, y se encarga de mantener su capacidad proliferativa, compitiendo con los factores proneurogénicos (Bylund et al., 2003). Es uno de los factores que intervienen en la inducción de células troncales pluripotentes a partir de otros tejidos, tanto en animales (Takahashi y Yamanaka, 2006) como en humanos (Takahashi et al., 2007; Yu et al., 2007). Además, interacciona con Pax6 en distintos momentos de la morfogénesis del ojo (Hever et al., 2006; Inoue et al., 2007; Smith et al., 2009). Está implicado en la diferenciación de células amacrinas en la retina del pollo (Rouëdec et al., 2002) y de 
1.4. Detección y caracterización de las células progenitoras

ratón (Lin et al., 2009), y se mantiene su expresión en células amacrinas colinérgicas diferenciadas (Fischer et al., 2010a), también en el pez cebra (Jusuf y Harris, 2009). Sox2 se expresa en células gliales en la retina, como en astrocitos (Fischer et al., 2010a) y en células de Müller (Taranova et al., 2006). Su mutación se ha relacionado con la anoftalmia (Fantes et al., 2003; Hever et al., 2006; Williamson et al., 2006), y podría estar relacionado también con distintos tipos de cánceres (Pevny y Nicolis, 2010).

\subsubsection{Islet1}

Islet 1 es un factor de transcripción potenciador del gen de la insulina, y fue descrito por primera vez por Karlsson et al. (1990) en células pancreáticas. Forma parte de la familia de homeoproteínas LIM (Karlsson et al., 1990; Dawid et al., 1995). Está implicado en la determinación celular en algunos sistemas tisulares, tales como las motoneuronas (Ericson et al., 1992; Appel et al., 1995) y otras neuronas del SNC (Thor et al., 1991), y actúa en combinación con factores de transcripción bHLH (hélice-bucle-hélice básica) como NeuroD (Korzh et al., 1998). Se ha utilizado Islet1 como un marcador de células troncales multipotentes en el corazón de ratón (Moretti et al., 2006), humano (Bu et al., 2009) y pez cebra (Hami et al., 2011).

En la retina, Islet1 se expresa principalmente en células ganglionares, y de hecho se utiliza como marcador de dichas células en el pollo (Austin et al., 1995) y en ratón (Marchena et al., 2011). Se ha descrito que Islet1 está implicado en la diferenciación de células amacrinas colinérgicas de rata (Galli-Resta et al., 1997) y de ratón (Elshatory et al., 2007b), y en bipolares ON de ratón (Elshatory et al., 2007b) y de humanos (Haverkamp et al., 2003). Se expresa también en las células horizontales sin axón en el pollo (Fischer et al., 2007; Edqvist et al., 2008; Suga et al., 2009) y en el cerdo (Guduric-Fuchs et al., 2009). En el ratón, regula el número de células horizontales, aunque no se expresa en células adultas (Whitney et al., 2011). Los estudios sobre la expresión de Islet1 en la retina de teleósteos se han hecho principalmente durante el desarrollo. Así, se sabe que en el pez cebra, las primeras células positivas para Islet1 aparecen a las 24 horas post-fecundación (Korzh et al., 1993) y que a lo largo del desarrollo se expresa en células ganglionares, horizontales, amacrinas y bipolares (Shkumatava et al., 2004; Shkumatava y Neumann, 2005). En la retina de 


\section{Introducción}

tenca adulta se encuentra también en los cuatro tipos de células (Bejarano-Escobar et al., 2009), al igual que en el carpín (Sánchez-González, 2009).

\subsubsection{Sonic Hedgehog (SHH)}

La proteína Sonic Hedgehog (SHH) pertenece a la familia de proteinas Hedgehog. Fueron descubiertas por primera vez en Drosophila y su nombre proviene de las púas que desarrollan los mutantes, similares a las de un erizo (hedghog en inglés) (NüssleinVolhard y Wieschaus, 1980). Son moléculas altamente conservadas desde las moscas hasta los mamíferos y funcionan como proteínas de señalización intercelular. En el pez cebra hay dos genes que codifican para Shh, Shh

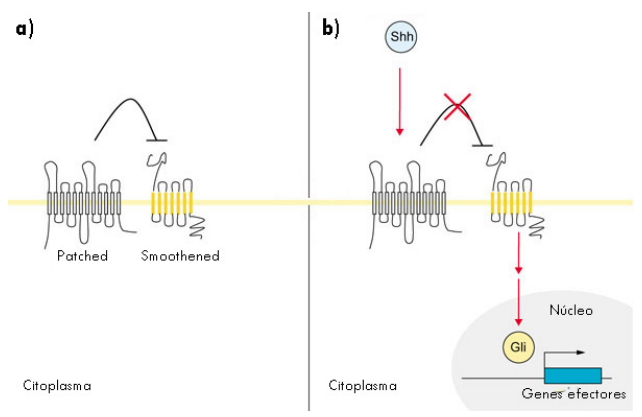

Figura 1.13: Ruta de acción de la proteína Sonic Hedgehog. Modificado de Weitzman (2002) a y Shh b, conocido este último también como Twhh (de las siglas en inglés de Tiggy-winkle hedgehog). Ambas están implicadas en el establecimiento de patrones en el desarrollo mediante la unión al receptor Patched (Ptc). Esta unión activa a la proteína transmembrana Smoothened (Smo) que regula la expresión de factores de transcripción Gli (Ingham et al., 1991) (Fig. 1.13).

Shh es una proteína clave en la inducción de la formación de los pedúnculos ópticos. Más adelante en el desarrollo, se encuentra en las células del epitelio pigmentario, las celulas ganglionares y las células amacrinas, siendo la encargada de la salida del ciclo celular de las células en división y su transformación en los distintos tipos celulares (Stenkamp et al., 2000; Shkumatava et al., 2004; Shkumatava y Neumann, 2005). Es un factor fundamental para el mantenimiento de los fotorreceptores en peces cebra adultos (Stenkamp et al., 2008); y en cultivos de células de mamíferos las dirige hacia bastones (Levine et al., 1997; Osakada et al., 2008). 


\subsubsection{Nestina}

La nestina es una proteína del citoesqueleto que pertenece a la familia de los filamentos intermedios de tipo VI (Liem, 1993) y Forma heterodímeros con vimentina y desmina (Sjöberg et al., 1994; Marvin et al., 1998), entre otros. También interviene en procesos de reorganización celular que facilitan procesos característicos de células indiferenciadas, como son la migración y la mitosis (Palm et al., 2000; Rietze et al., 2001).

Fue descrita por primera vez en células mitóticamente activas del Sistema Nervioso Central y del Sistema Nervioso Periférico que eran capaces de generar tanto neuronas como células gliales durante la embriogénesis temprana (Hockfield y McKay, 1985), y en células troncales neuroepiteliales (Lendahl et al., 1990). Posteriormente se ha descrito en tejido no neural, como el páncreas (Delacour et al., 2004) y el intestino (Rauch et al., 2006).

Se ha demostrado que la nestina es un marcador de células multipotentes, que dan lugar a varios linajes neurales en el Sistema Nervioso adulto (Steinert et al., 1999; Messam et al., 2000; Sahlgren et al., 2001), aunque también se expresa en glía radial (Hockfield y McKay, 1985) y en astrocitos reactivos (Clarke et al., 1994). Durante el desarrollo, la presencia de nestina es necesaria para regular la apoptosis, aunque se desconoce el mecanismo concreto de regulación (Chen et al., 2010).

En la retina humana la nestina se expresa tanto en la CCG como en la CNI (Mayer et al., 2003). En la retina de los teleósteos, se ha demostrado que se expresa ampliamente en la CNI tanto en el esturión (Fang et al., 2009) como en el carpín (Sánchez-González, 2009).

\subsubsection{Calretinina}

La calretinina (CR) o calbindina 2, es una proteína ligante de calcio de $29 \mathrm{kDa}$, descubierta por primera vez en la retina del pollo (Rogers, 1987). Forma parte de la familia de proteínas mano EF, junto con la parvalbúmina o la calmodulina. Se expresa principalmente en las neuronas del Sistema Nervioso Central implicadas en órganos sensoriales (Resibois y Rogers, 1992). En peces hay expresión de calretinina 


\section{Introducción}

en el techo óptico de tenca (Arévalo et al., 1995) y del pez cebra (Castro et al., 2006; Arenzana et al., 2011), en el área preóptica de la trucha (Castro et al., 2003) y en las fibras del sistema electrosensorial en peces mormíridos (Friedman y Kawasaki, 1997). En la retina del pez cebra se empieza a expresar a las 48 horas post fecundación, con un marcaje correspondiente a células amacrinas (Arenzana et al., 2011). Posteriormente, se expresa en las células ganglionares y en amacrinas de la CNI, y esta distribución se mantiene hasta la edad adulta (Yazulla y Studholme, 2001; García-Crespo y Vecino, 2004; Arenzana et al., 2011; Cederlund et al., 2011). Se observa un gradiente de expresión, sin marcaje en la ZPG y con un marcaje cada vez más intenso a medida que nos acercamos a la retina más central (García-Crespo y Vecino, 2004; Lima et al., 2007).

La calretinina está implicada en los procesos de diferenciación de las células progenitoras (Brandt et al., 2003; Kempermann et al., 2004), y se ha utilizado como marcador de diferenciación en la retina (Fischer et al., 2002b; Karl et al., 2008; Ferreiro-Galve et al., 2010) y en cultivos de células progenitoras (Yang et al., 2002; Lawrence et al., 2007) 
Capítulo 2

Justificación, hipótesis y objetivos 
2. Justificación, hipótesis y objetivos 
La reciente caracterización de progenitores neurales en la retina adulta de mamíferos (Ahmad et al., 2000; Tropepe et al., 2000), genera perspectivas sobre el tratamiento de las principales enfermedades retinianas mediante terapias celulares (Bull y Martin, 2011; Tibbetts et al., 2012). Estos progenitores, sin capacidad de división in vivo en la retina de mamíferos adultos, proliferan in vitro. Los datos preliminares sobre el tratamiento de las enfermedades retinianas indican que el grado de diferenciación de las células es determinante para su correcta inserción, integración y funcionalidad (MacLaren et al., 2006).

Como modelo de estudio, los teleósteos suponen una ventaja en la neurogénesis adulta en comparación al resto de vertebrados, ya que poseen en el SNC varios nichos en los que tiene lugar proliferación celular durante toda la vida adulta (Hinsch y Zupanc, 2006; Zupanc, 2008). Esto les permite no sólo generar nuevas neuronas durante toda la vida del individuo, sino también regenerar lesiones (Jimeno, 2001; Morris et al., 2008). En el caso de la retina, además de la zona periférica germinal (Müller, 1952), presente también en otros grupos de animales (Hollyfield, 1968; Hitchcock et al., 2004), hay otro nicho de proliferación en la retina central (Otteson et al., 2001; Kassen et al., 2008). Se conoce la existencia de estos nichos desde los estudios de Johns (1982) y la caracterización de dichas células se ha realizado básicamente en carpín (Cid et al., 2002; Sánchez-González, 2009). En el pez cebra pocos datos sobre estos y su evolución in vivo e in vitro .

En nuestro laboratorio se ha desarrollado un protocolo para el cultivo de las células progenitoras del carpín (Sánchez-González, 2009). Dado el extenso conocimiento que se posee sobre el genoma del pez cebra, el uso del protocolo anteriormente citado nos puede aportar más datos sobre el comportamiento de los progenitores retinianos en los peces teleósteos.

La hipótesis de partida es que los progenitores retinianos del pez cebra adulto, caracterizados mediante estudios ex vivo con distintos marcadores, permitirán seleccionar y cultivar progenitores neurales en medios específicos adaptados para el pez cebra, además de conseguir neuroesferas y condicionar la diferenciación de las mismas hacia los distintos tipos celulares.

El objetivo general de esta Tesis Doctoral es la caracterización de las células progenitoras neurales de retina adulta de pez cebra tanto ex vivo como in vitro. Los 
objetivos concretos de la misma son:

- Establecer un protocolo de administración de BrdU que permita marcar el mayor número posible de células en proliferación.

- Analizar la evolución de las poblaciones de los progenitores retinianos a largo plazo.

- Caracterización morfológica y funcional de dos poblaciones de células progenitoras de la retina del pez cebra: los progenitores de la zona periférica germinal y de los precursores de bastones de las capas nucleares interna y externa de la retina madura.

- Desarrollar un protocolo de cultivo primario para células de retina adulta de pez cebra, y determinar las características de viabilidad y proliferación de las mismas.

- Describir la evolución temporal de la expresión de marcadores en neuroesferas de progenitores neurales de retina adulta del pez cebra.

- Analizar la diferenciación de los progenitores neurales de retina de pez cebra en cultivos de neuroesferas. 
Capítulo 3

Material y métodos 
3. Material y métodos 


\subsection{Animal de experimentación}

\subsubsection{Danio rerio (Hamilton, 1822)}

El pez cebra, Danio rerio, (Fig. 3.1)

es un pez tropical de agua dulce de la familia Cyprinidae, subfamilia Rasborinae, que está emparentado con las carpas y los barbos. Es originario del sudeste asiático y se encuentra en los ríos del norte de India, norte de Pakistan, Bhutan y Nepal. Es muy común en acuarios, debido a su fácil manejo. En 1970 se empezó a utilizar

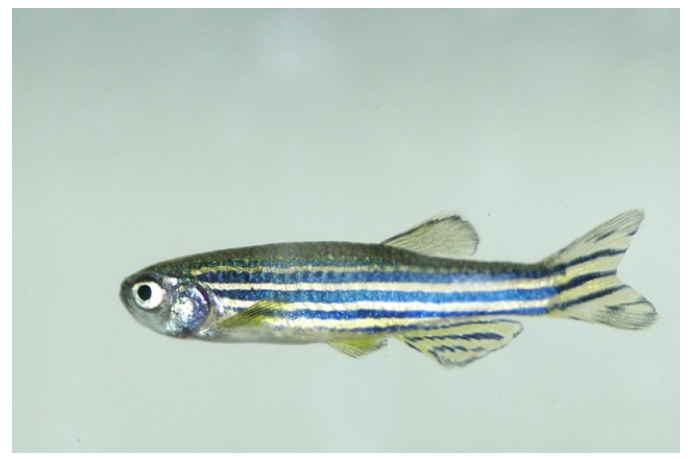

Figura 3.1: Ejemplar adulto de pez cebra en los laboratorios (Streisinger et al., 1981), pero su uso para estudios de biología del desarrollo no se generalizó hasta los años 90 (Schilling y Webb, 2007). Es un organismo diploide que posee 25 pares de cromosomas y tiene un genoma compuesto por 1700 millones de pares de bases. Tiene un genoma duplicado probablemente después de la separación de los linajes de tetrápodos y teleósteos (Woods et al., 2000). Con aproximadamente tres centímetros de largo, este teleósteo ofrece numerosas ventajas en investigación y así, por ejemplo su corto tiempo de generación lo hace ideal para estudios genéticos (Wixon, 2000). Otra de las características que lo hacen especialmente interesante en investigación, es la capacidad del cerebro adulto de producir nuevas neuronas en condiciones normales y de regeneración tras una lesión (Zupanc, 2008).

\subsubsection{Manipulación de los animales}

En este trabajo experimental hemos utilizado ejemplares adultos silvestres, suministrados por Hobby Acuarium, Salamanca.

Los animales se mantuvieron en acuarios de tamaño apropiado y en condiciones adecuadas de aireación y alimentación. Se estableció un fotoperiodo de $14 \mathrm{~h}$ de luz y $10 \mathrm{~h}$ de oscuridad. La temperatura del agua se mantuvo a $20{ }^{\circ} \mathrm{C}\left( \pm 2{ }^{\circ} \mathrm{C}\right)$. En todos 
los casos los estudios se realizaron tras un periodo de adaptación mínimo de una semana.

Para su procesamiento, los animales se anestesiaron sumergiéndolos en una solución de metasulfonato de tricaína (MS-222, Sigma) a una concentración de 0,2 g/L. El sacrificio se realizó mediante decapitación.

Todos los protocolos de mantenimiento, manipulación y sacrificio de los animales se llevaron a cabo cumpliendo las directrices del Consejo de las Comunidades Europeas (86/609/EEC, 2003/65/EC y 2010/63/EU) y de la legislación española (RD 1201/2005 de 10 de octubre, BOE de 21 de octubre de 2005) vigentes para el uso y cuidado de animales de laboratorio, y bajo la supervisión del Servicio de Experimentación Animal (SEA) de la Universidad de Salamanca.

\subsubsection{Pinzamiento del nervio óptico}

Partiendo del protocolo descrito por Parrilla-Monge (2010) para el pinzamiento del nervio óptico del carpín, hemos adaptado los procedimientos para el pez cebra.

Los peces anestesiados se colocaron bajo una lupa y se recortó parte del tejido conjuntivo que rodea al ojo. Con ayuda de unas pinzas se giró el ojo para tener acceso al nervio óptico y se pinzó durante unos 3 segundos, teniendo cuidado de no dañar la arteria central.

\subsection{Procesamiento de los ojos para estudio de secciones}

\subsubsection{Inyección de BrdU}

Una vez anestesiados los animales, se inyectaron en el abdomen $30 \mu \mathrm{L}$ de una solución de 30mg/mL de BrdU (Sigma) disuelta en suero fisiológico. Esta inyección fue única para el estudio a largo plazo, o se repitió cuatro veces en días alternos, para los estudios de caracterización. Durante el tratamiento los animales fueron 
mantenidos en agua con azul de metileno y cristal violeta, para prevenir infecciones. El azul de metileno funciona como un bactericida de bajo espectro, mientras que el cristal violeta o violeta de cresilo actúa como antifúngico y bactericida. El día posterior a la última inyección los peces fueron sacrificados y los ojos extraídos para ser tratados mediante la técnica inmunohistoquímica.

\subsubsection{Extracción del ojo}

Tras el sacrificio de los peces según lo descrito en el apartado anterior (3.2.1), se procedió a la extracción del globo ocular cortando la musculatura extraocular y el nervio óptico. Para facilitar el acceso de las soluciones a la retina, se extrajo el cristalino realizando una incisión en la cornea.

\subsubsection{Fijación y corte}

Para preservar la estructura y características del tejido vivo, el globo ocular fue fijado en una solución de paraformaldehido al $4 \%$ en tampón fosfato 0,1 M pH 7,4, durante una noche a $4^{\circ} \mathrm{C}$. Después, los ojos se lavaron tres veces, durante 10 minutos cada vez, en tampón fosfato a fin de eliminar los posibles restos de fijador y evitar así una sobrefijación.

A continuación los ojos se crioprotegieron en una solución de sacarosa al $30 \%$ en tampón fosfato. Cuando los ojos estaban crioprotegidos, o bien se reservaron en una solución congeladora a $-20^{\circ} \mathrm{C}$ hasta su uso, o bien se encastraron en un molde con agar al 1,5\% y sacarosa, que fue de nuevo crioprotegido en la solución de sacarosa al $30 \%$ en tampón fosfato.

Los bloques se embebieron en un producto adecuado para la congelación (OCT, Tissue-Teck, Sakura) y fueron congelados sobre una base metálica enfriada con nitrógeno líquido. En un criostato (Leica) se realizaron cortes de $12 \mu \mathrm{m}$ de grosor siguiendo un plano de orientación naso-temporal (Fig. 3.2). Las secciones se recogieron sobre portaobjetos gelatinizados. Tras secar las secciones, se mantuvieron a $-20^{\circ} \mathrm{C}$ hasta su uso. 


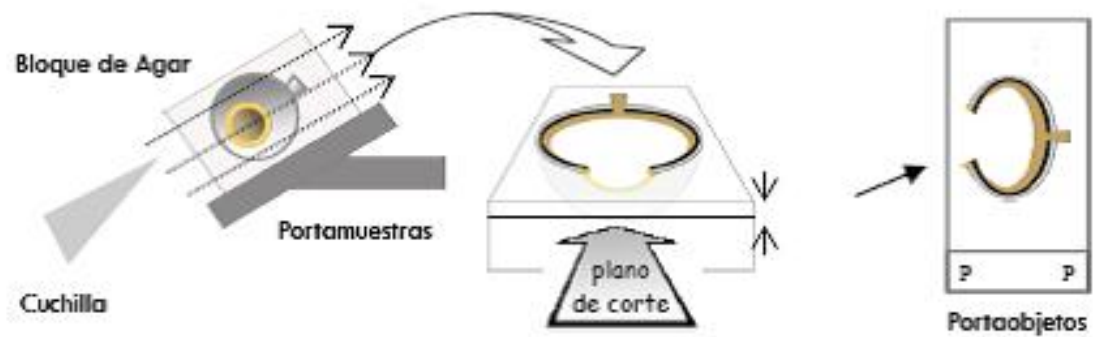

Figura 3.2: Proceso de corte esquematizado

\subsection{Cultivo de células retinianas}

\subsubsection{Pretratamiento de los animales}

Los peces utilizados para estos experimentos fueron estabulados durante una semana previa al experimento en agua con azul de metileno y cristal violeta a fin de reducir al mínimo la contaminación.

El día previo al experimento los peces fueron mantenidos en oscuridad para facilitar el aislamiento de la retina, ya que, como se ha comentado en la introducción, en oscuridad los segmentos externos de los bastones se retraen y es más fácil separar la retina del epitelio pigmentario.

\subsubsection{Extracción y disgregación de las retinas}

Una vez anestesiados los animales en una solución de metanosulfonato de tricaína (MS-222, Sigma) a una concentración de 0,3 g/L, se extrajeron los ojos y se realizó el procedimiento para aislar la retina. Se separan las capas más externas del globo ocular, la esclera y la coroides por el polo posterior, tras lo cual se extrae la córnea, el iris y el cristalino. El último paso es separar la retina del epitelio pigmentario y cortar la porción restante de nervio óptico. El aislamiento se llevó a cabo bajo una lupa en una sala esteril y en el medio Leibovitz L15 (Invitrogen, CA, EEUU) con Ciprofloxacino y Fungizona. Las retinas se aislaron de forma individual en placas de $60 \mathrm{~mm}$. Todo el material quirúrgico utilizado fue esterilizado previamente.

Las retinas aisladas se lavaron en el medio de extracción y se realizó una digestión 
enzimática en $5 \mathrm{~mL}$ de una solución denominada PDD en un baño a $37^{\circ} \mathrm{C}$ durante 10 minutos, acompañado por la disgregación mecánica con una pipeta serológica. La solución PDD contiene 0,01\% de papaína (Sigma), 0.1\% de dispasa II (Roche) y $0.01 \%$ de DNAsa I (Roche) disuelto en solución de Hank's (Invitrogen).

Después se pasó a centrifugar la muestra obtenida a $1200 \mathrm{rpm}$ durante 5 min y el pellet se resuspendió en el medio de cultivo. Las células se lavaron dos veces más repitiendo el mismo procedimiento.

\subsubsection{Cultivo de las células}

Las células, tras cribarlas con un tamiz celular de $40 \mu \mathrm{m}$, se cultivaron en dos frascos de cultivo con $8 \mathrm{~mL}$ de medio de cultivo consistente en medio Neurobasal A suplementado con B27 (Gibco), estreptomicina, penicilina, heparina, L-Glutamina y anfotericina $\mathrm{C}$ en las concentraciones determinadas (Sánchez-González, 2009) (Cuadro 3.1). Antes de utilizar el medio se añadió ciprofloxacino, el factor de crecimiento epidérmico (EGF, de sus siglas en inglés) y el factor de crecimiento de fibroblastos básico (bFGF, de sus siglas en inglés).

\begin{tabular}{|c|c|c|}
\hline \multicolumn{3}{|c|}{ Medio Neurobasal A suplementado } \\
\hline \multirow{2}{*}{ Factores de crecimiento } & EGF & $20 \mathrm{ng} / \mathrm{mL}$ \\
& bEGF & $20 \mathrm{ng} / \mathrm{mL}$ \\
\hline \multirow{3}{*}{ Antibióticos } & Estreptomicina & $100 \mathrm{U} / \mathrm{mL}$ \\
& Penicilina & $100 \mathrm{U} / \mathrm{mL}$ \\
& Ciprofloxacino & $1 \mu \mathrm{g} / \mathrm{mL}$ \\
\hline Antifúngico & Anfotericina B & $100 \mu \mathrm{g} / \mathrm{mL}$ \\
\hline Suplemento comercial & B27 & $20 \mu \mathrm{L} / \mathrm{mL}$ \\
\hline \multicolumn{2}{|c|}{ L-Glutamina } & $200 \mathrm{mM}$ \\
\hline \multicolumn{2}{|c|}{ Heparina } & $2 \mu \mathrm{g} / \mathrm{mL}$ \\
\hline
\end{tabular}

Cuadro 3.1: Composición del medio utilizado para los cultivos

Cada dos días se añadieron los factores de crecimiento, y cuando se formaban neuroesferas suficientemente grandes se procedió a disgregarlas. Para ello se recogió el medio y se centrifugó a 1200 rpm durante 5 minutos. El sobrenadante se recogió y se filtró con un filtro de $0,22 \mu \mathrm{m}$ y se reservó para resembrar las células. Sobre el pellet se añadieron $400 \mu \mathrm{L}$ de Accutase (Millipore) previamente atemperada a $37^{\circ} \mathrm{C}$. Se incubaron las células durante 5 minutos a $37^{\circ} \mathrm{C}$ y luego se disgregaron las esferas 
mecánicamente con una pipeta. Para parar la reacción enzimática se añadieron 2 mL de medio Neurobasal A y se repitió la centrifugación. El pellet se resuspendió en medio de cultivo fresco y medio de cultivo reservado anteriormente a partes iguales en el doble de volumen en el que estaban sembradas anteriormente.

\subsubsection{Estudio de la viabilidad del cultivo mediante el ensayo MTT}

Para estudiar la viabilidad de las células del cultivo se realizó la prueba del MTT (Mosmann, 1983). Este ensayo se basa en la reducción metabólica del Bromuro de 3-(4,5-dimetiltiazol-2-ilo)-2,5-difeniltetrazol (MTT), realizada por la enzima mitocondrial succinato-deshidrogenasa, en un compuesto coloreado de color azul (formazan) (Fig. 3.3), lo que permite determinar la funcionabilidad mitocondrial de las células tratadas. Dado que el formazán se produce en forma de cristales, hay que añadir al medio un detergente para hacer soluble el formazán y poder medirlo en un espectrofotómetro.

Según el protocolo, se incubaron los cultivos con MTT disuelto en el medio de cultivo al $1 \%$ durante 75 minutos. Tras centrifugar a $1200 \mathrm{rpm}$ durante 5 minutos, se resuspendió el pellet en $400 \mu \mathrm{L}$ de dimetil sulfoxido (DMSO, Sigma) y se agitó durante 10 minutos. Después de una segunda centrifugación, se midió la absorbancia en una placa de Elisa en un fotometro.
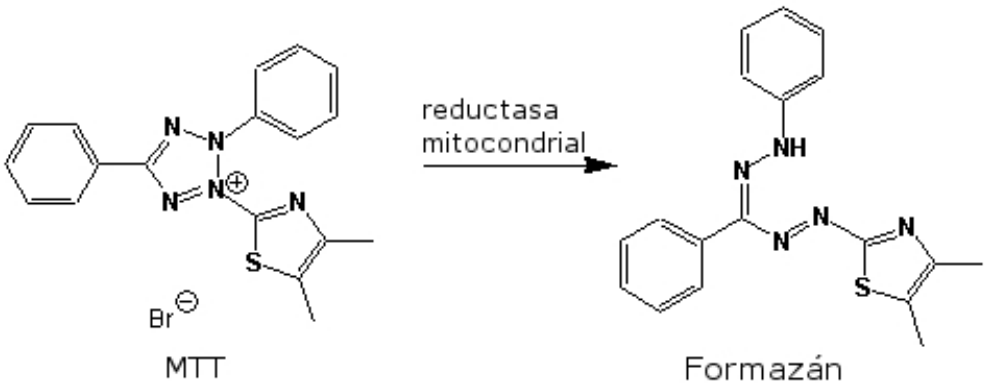

Figura 3.3: Reacción de reduccion de la MTT a formazán 


\subsection{Inmunohistoquímica}

La técnica inmunohistoquímica se basa en la unión antígeno-anticuerpo, y se utiliza para localizar a nivel tisular y celular una proteína. En este trabajo se ha utilizado tanto el método avidina-biotina peroxidasa, para estudiar los patrones de distribución de las proteínas, como la inmunofluorescencia para analizar la colocalización de distintas proteínas.

Una vez descongeladas las secciones a temperatura ambiente durante al menos 30 minutos, se procedió a su rehidratación en tampón fosfato mediante tres lavados de cinco minutos cada uno en agitación.

Las secciones se incubaron en el anticuerpo primario en la concentración expresada en el cuadro 3.2 , durante 48 horas a $4^{\circ} \mathrm{C}$ en una solución de tampón fosfato con $0,2 \%$ Triton X-100 y $5 \%$ de suero del animal en que está hecho el anticuerpo secundario.

Previamente a la incubación en el anticuerpo primario, las secciones de los ojos de los animales que habían sido expuestos a BrdU fueron mantenidas en $\mathrm{HCl} 2 \mathrm{~N}$ a $37^{\circ} \mathrm{C}$ durante 40 minutos, para facilitar el acceso del anticuerpo a dicho compuesto. Para neutralizar el ácido clorhídrico las secciones fueron lavadas en tampón borato $9,7 \mathrm{mM} \mathrm{pH} 8,5$.

\subsubsection{Método avidina-biotina-peroxidasa}

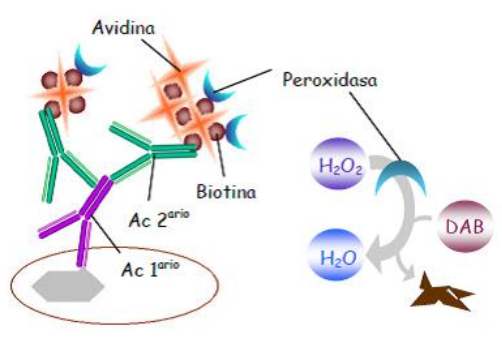

Figura 3.4: Técnica inmunohistoquímica por la técnica $\mathrm{ABC}$
Este método amplifica enormemente la señal inmunocitoquímica. Se utiliza un anticuerpo secundario que es detectado por un complejo constituido por avidina, biotina y peroxidasa. Durante el proceso de revelado, la peroxidasa realiza su actividad acoplada a la oxidación del cromógeno DAB, que en estado reducido es soluble y de color violeta, y al ser oxidado forma precipitados de color marrón (Fig. 3.4). 
Una vez finalizada la incubación en el anticuerpo primario, las secciones fueron lavadas tres veces, durante 10 minutos cada una, en tampón fosfato. Una vez finalizados los lavados, se incubaron en el anticuerpo secundario biotinilado apropiado (Cuadro 3.3) en una concentración 1:250 en una solución de tampón fosfato, 0,2\% Triton X-100 y $5 \%$ de suero durante una hora a temperatura ambiente.

El exceso de anticuerpo secundario fue eliminado mediante lavados en tampón fosfato. Posteriormente se realizó una incubación de hora y media a temperatura ambiente con el complejo avidina-biotina-peroxidasa (kit ABC, Vector) a una dilución de 1:250 en el medio de incubación. Tras lavar las secciones en tampón fosfato, se hizo un último lavado con tampón Tris-clorhídrico $0,1 \mathrm{M}$ pH 7,6 y se procedió al revelado mediante $\mathrm{H}_{2} \mathrm{O}_{2}$ al $0,0033 \%$ y el cromógeno 3,3'-diaminobenzidina (DAB) (Sigma-Aldrich) en tampón Tris-clorhídrico 0,1M. La reacción se controló bajo el microscopio y se detuvo lavando las secciones en Tris-clorhídrico 0,1M pH 7,6. Finalmente, las secciones se deshidrataron en una batería de alcoholes de gradación creciente y xilol y se montaron con Entellan (Merck).

\subsubsection{Método inmunofluorescente}

Para la realización de la técnica se siguió un método indirecto, utilizando un anticuerpo secundario conjugado con una molécula fluorescente. Este sistema permite analizar dos antígenos en la misma sección de tejido, combinando anticuerpos primarios obtenidos en especies diferentes, y los respectivos anticuerpos secundarios conjugados con moléculas de distintos espectros de absorción y emisión (Fig. 3.5).

Tras la incubación en el anticuerpo primario, las secciones fueron lavadas en tampón fosfato al que se le añadió $4 \%$ de gelatina de pez a fin de minimizar la autofluorescencia de los fotorreceptores. Posteriormente se incubaron en la misma solución con el anticuerpo secundario unido a un fluorocromo diluido a 1:250 (Cuadro 3.3), durante una hora a temperatura ambiente y en oscuridad.

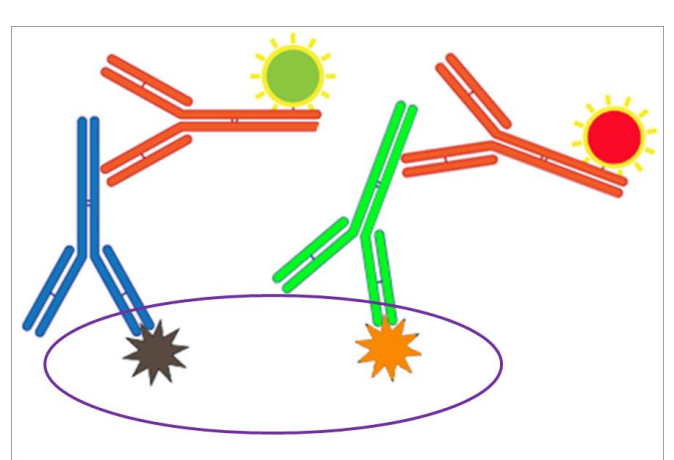

Figura 3.5: Esquema del método inmunofluorescente 
Por último, y tras tres lavados en tampón fosfato se hizo una incubación en 4',6diamidino-2-fenilindol (DAPI; Sigma) a 1:10 durante 7 minutos a temperatura ambiente a fin de marcar los núcleos de las células. Para conservar las secciones, se montaron con un medio protector de la fluorescencia compuesto por Glicina 0,42\%, $\mathrm{NaOH} 0,021 \%, \mathrm{NaCl}$ 0,51\%, azida sódica $0,03 \%$, N-propil-galato $5 \%$ y glicerol $70 \%$, disuelto en agua destilada.

\subsubsection{Controles de la técnica inmunohistoquímica}

Para comprobar la especificidad de la técnica inmunohistoquímica se realizaron los siguientes controles:

1. Omisión de los anticuerpos primarios para detectar uniones inespecíficas de los anticuerpos secundarios.

2. Eliminación del anticuerpo secundario biotinilado, para confirmar que no había unión del complejo ABC al tejido.

3. Ausencia del complejo ABC, para comprobar que el marcaje no se debía a una actividad peroxidasa endógena.

4. Omisión del anticuerpo secundario fluorescente, para comprobar que el marcaje no se debía a una autofluorescencia del tejido.

5. En el caso de los dobles marcajes, incubación con uno de los dos anticuerpos primarios y adición del anticuerpo secundario correspondiente al anticuerpo primario omitido para detectar una posible inmunorreactividad cruzada.

No hubo marcaje en la zona de interes en ninguno de los casos, aunque los fotorreceptores se marcaban inespecíficamente. 


\begin{tabular}{|c|c|c|c|}
\hline Antígeno & Anticuerpo & Dilución & Casa Comercial \\
\hline BrdU & IgG de rata monoclonal & $1: 5000$ & Abcam \\
\hline Pax6 & IgG de conejo policlonal & $1: 500$ & Covance \\
\hline Prox1 & IgG de conejo policlonal & $1: 500$ & Covance \\
\hline Sox 2 & IgG de conejo policlonal & $1: 500$ & Abcam \\
\hline Calretinina & IgG de ratón policlonal & $1: 10000$ & Swant \\
\hline
\end{tabular}

Cuadro 3.2: Anticuerpos primarios utilizados

\begin{tabular}{|c|c|c|c|c|}
\hline Método & Antígeno & Anticuerpo & Conjugado & Casa Comercial \\
\hline \multirow{2}{*}{ ABC } & IgG de rata & IgG de cabra & Biotina & Vector \\
& IgG de conejo & IgG de cabra & Biotina & Vector \\
\hline \multirow{5}{*}{ Fluorescencia } & IgG de rata & IgG de cabra & Cy2 & Jackson \\
& IgG de conejo & IgG de cabra & Cy3 & Jackson \\
& IgG de conejo & IgG de cabra & Cy2 & Jackson \\
& IgG de ratón & IgG de cabra & Cy3 & Jackson \\
\hline
\end{tabular}

Cuadro 3.3: Anticuerpos secundarios utilizados

\subsection{Inmunocitoquímica de cultivos}

\subsubsection{Fijación de las neuroesferas}

A fin de poder analizar las neuroesferas, el primer paso es adherirlas a un cubreobjetos. Para ello se recubren los cubreobjetos con Matrigel ${ }^{\circledR}$ (BD Biosciences), diluyéndolo en el medio de cultivo a una concentración de 1:50. Se utilizaron $300 \mu \mathrm{L}$ de la dilución para cada uno de los cubreobjetos, y se incubaron a $37^{\circ} \mathrm{C}$ durante al menos 3 horas.

Una hora antes de adherir las neuroesferas a los cubreobjetos, se incubaron con una solución con $5 \mu \mathrm{M}$ de BrdU, a fin de que las células que se dividan durante esa hora, incorporen el producto.

Para adherir las neuroesferas se repartieron $500 \mu \mathrm{L}$ del medio donde han crecido y que contiene las neuroesferas, en cada uno de los pocillos con un cubreobjetos pretratado con Matrigel. Tras dejarlo 15 minutos a $37^{\circ} \mathrm{C}$ se retiró el medio, y se fijaron las células con una solución de $4 \%$ de paraformaldehido durante 20 minutos. 


\subsubsection{Inmunocitoquímica}

Una vez fijadas las células, se lavan los cubreobjetos y se realiza la técnica inmunocitoquímica siguiendo un protocolo similar al descrito anteriormente para la inmunohistoquímica. La única diferencia es que el tiempo de incubación con $\mathrm{HCl}$ $2 \mathrm{~N}$ a $37^{\circ} \mathrm{C}$ se reduce a 10 minutos. Una vez lavados con tampón borato, los cubreobjetos se incuban con el anticuerpo primario (Cuadro 3.2). Tras dejarlos una noche a temperatura ambiente, se lavan y se procede a la incubación con los anticuerpos secundarios fluorescentes correspondientes (Cuadro 3.3), junto con Topro3 (Invitrogen) (Suzuki et al., 1997) a una concentración de 1:1000 para marcar los núcleos.

\subsection{Western blot}

Para estudiar la expresión de determinadas proteínas en los cultivos se realizó una electroforesis SDS-PAGE. El anticuerpo contra BrdU no fue testado por Western Blot ya que reconoce un molécula sintética comercial.

Para extraer las proteínas se utilizaron $2 \mathrm{~mL}$ de cultivo. El primer paso para la extracción de las proteínas fue centrifugar las células a 4000 rpm durante 5 minutos. Una vez retirado el sobrenadante se resuspende el pellet en $50 \mu \mathrm{L}$ de $\mathrm{RIPA}^{\circledR}$ con el inhibidor de proteasas a 1:100, y se deja agitando en hielo durante dos horas. Tras esto, se centrifuga a $14000 \mathrm{rpm}$ durante 10 minutos a una temperatura de $4^{\circ} \mathrm{C}$. Se conserva el sobrenadante en un eppendorf limpio a $-80^{\circ} \mathrm{C}$ hasta el momento de realizar el procedimiento.

Antes de realizar la técnica medimos la cantidad de proteínas presentes en cada una de las muestras mediante el método de Bradford en placas de ELISA. Para ello, se realiza una recta patrón con distintas concentraciones de albúmina sérica bovina (BSA), y se calcula la concentración de proteínas midiendo la absorbancia de cada una de las muestras por duplicado, añadiendo a todas las muestras y a la recta patrón el reactivo de Bradford (Sigma).

Para la realización de la electroforesis decidimos cargar $30 \mu \mathrm{g}$ de proteína por pocillo, a partir de las muestras anteriores. A cada alícuota con los $30 \mu \mathrm{g}$ de proteína 
le añadimos:

- Tampón de carga: compuesto por una solución de $\beta$-mercaptoetanol al 5X y diluido en esta solución hasta el 1,25X.

- Agua MiliQ, hasta completar los $40 \mu \mathrm{L}$ de volumen que se cargaron por pocillo.

Tras la adición de estas cantidades se calentaron las muestras a $90^{\circ} \mathrm{C}$ durante 5 min para desnaturalizar las proteínas, e inmediatamente después se pusieron en hielo para impedir la renaturalización.

Posteriormente se realizó la electroforesis. Para ello se usaron dos geles. El primero de ellos es el gel separador. Se sitúa en la parte inferior de la electroforesis en columna y será por el que migren las proteínas separándose en función de su peso molecular. Usamos un gel al $10 \%$ compuesto por acrilamida-bisacrilamida (30\%0,3\%; Applichem), 1:5 solución tris glicina glicerol (TGGS), $20 \%$ de SDS (dodecil sulfato de sodio), 1:100 de persulfato amónico (APS) y 1/2000 de N,N,N',N'tetrametiletilendiamina (TEMED), todo ello en agua ultrapura. El segundo gel es el encargado de acumular todas las proteínas para que migren a la vez. Se situó en la parte superior de la electroforesis. Hemos usado un gel al $4 \%$ formado por: acrilamida-bisacrilamida (30-0,3\%), 1:5 de solución tris EDTA glicerol o TEG (0,35 M Tris- $\mathrm{HCl}$ a pH 6,7, 20 mM etilendiamina, EDTA y 25\% glicerol), 1/50 de SDS, $20 \%, 1: 100$ de APS (BioRad) y 1:1000 de TEMED en agua ultrapura. Este gel se añadió sobre el primero una vez que el separador estuvo polimerizado. Añadido el segundo gel, se dejó polimerizar tras poner el peine que permite la formación de los diez pocillos.

Se cargaron cada una de las muestras en cada uno de los pocillos del gel, acompañadas de un pocillo con $4 \mu \mathrm{L}$ de un marcador de pesos moleculares con proteínas estándar de pesos moleculares conocidos (Precision Plus ProteinTM Standards Dual Color de BioRad $\left.{ }^{\circledR}\right)$. El gel se dispuso en una cubeta mini-PROTEAN ${ }^{\circledR}$ con una fuente de alimentación PowerPac Basic ${ }^{\circledR}$ (BioRad). La cubeta de electroforesis se llenó con el tampón de migración formado por: TRIS base, 1,5 M de glicina y SDS en agua ultrapura. Para la migración de las proteínas se usó un voltaje de $90 \mathrm{~V}$ cuando las proteínas estaban en el gel concentrador, y de 120 V cuando estaban en el gel separador. 
Terminada la migración las proteínas fueron transferidas a una membrana de transferencia (InmobilonTM de Millipore ${ }^{\circledR}$ ), que debía ser activada con metanol antes de su uso. Para llevar a cabo dicha transferencia se dispuso el gel de la electroforesis con las proteínas migradas en el molde del sándwich junto con esponjillas, papeles de filtro y la membrana de transferencia. El sándwich se introdujo en una cubeta (Mini Trans-Blot de Bio $\operatorname{Rad}^{\circledR}$ ) con el tampón de transferencia formado por: $250 \mathrm{mM}$ de Tris-base a pH 8,3, 1,92 M de glicina, $200 \mathrm{~mL}$ de metanol y $700 \mathrm{~mL}$ de agua miliQ. Realizamos la transferencia en cámara fría a $4^{\circ} \mathrm{C}$ y con hielo durante una hora y media a una intensidad constante de $300 \mathrm{~mA}$.

Tras la transferencia teñimos la membrana con Rojo Ponceau al 0,1\% diluido en ácido acético al 5\%, para comprobar que la transferencia se había llevado a cabo correctamente, y que las proteínas se encontraban en la membrana. A continuación lavamos con agua destilada para eliminar el colorante.

Posteriormente se realizó sobre esta membrana una inmunodetección. Para ello se incubó la membrana durante dos horas en una solución que contenía leche en polvo desnatada al $3 \%$ y BSA al $1 \%$ en tris tamponado salino (TBS; 0,05M Tris Base, 4,5\% NaCl, pH 8.4) con Tween-20 (Sigma-Aldrich) al 1\%, a fin de bloquear posibles uniones inespecíficas. Tras esto, se utilizaron los anticuerpos anti-Pax6, anti-Prox1 y anti-Sox2 (Cuadro 3.3) en una solución de BSA y la membrana se dejó en agitación a $4^{\circ} \mathrm{C}$ durante toda la noche. La mañana siguiente, tras limpiar la membrana con TBST (TBS con Tween-20 al 1\%), se incubó con el anticuerpo secundario conjugado con peroxidasa de rábano a una concentración de 1:10000 durante dos horas a temperatura ambiente en TBST con BSA al $1 \%$ y leche en polvo desnatada al $3 \%$.

Después de lavar de nuevo la membrana (3 x 10 min), revelamos el marcaje, utilizando un kit de quimioluminiscencia para detectar el anticuerpo secundario (Western-blotting luminol reagent, Santa Cruz). Este kit posee $\mathrm{H}_{2} \mathrm{O}_{2}$ que se reduce en presencia de la peroxidasa. El luminol presente en la reacción se oxida, dando lugar a un compuesto que emite luz. Finalmente la membrana se expuso a una película fotográfica que detecta la señal quimioluminiscente. Las películas se revelaron manualmente sumergiéndolas en un medio de revelado, seguido de un medio de fijación. El tiempo en el que las películas están en el medio de revelado dependerá de la intensidad, variando entre un minuto y media hora. 


\subsection{Hibridación in situ}

La técnica de hibridación in situ (HIS) permite detectar un ARNm mediante la utilización de una sonda complementaria de 200 a 300 nucleótidos de longitud, cuyos uracilos llevan unida una partícula de digoxigenina. El revelado puede ser mediante el uso de anticuerpos asociados a fosfatasa alcalina o anticuerpos fluorescentes.

\subsubsection{Síntesis de las ribosondas}

Las ribosondas utilizadas fueron sintetizadas a partir de plásmidos amablemente cedidos por diversos laboratorios, a excepción de la sonda de nestina que se describe más adelante.

El primer paso consistió en la amplificación del plásmido circular en bacterias, con el fin de obtener una mayor cantidad del mismo para la síntesis de la ribosonda. Para este fin se utilizaron bacterias termo-competentes One shot ${ }^{\circledR}$ Top10F' (Invitrogen) y se siguió el protocolo indicado por el fabricante. Brevemente, el vial con las bacterias se descongeló en hielo durante media hora y se añadió $1 \mu \mathrm{L}$ de plásmido circular disuelto en agua. A continuación el vial se introdujo 30 segundos en un baño a $42^{\circ} \mathrm{C}$ e inmediatamente después se dispuso otra vez en hielo. Se añadieron al vial $250 \mu \mathrm{L}$ de medio SOC precalentado a $37^{\circ} \mathrm{C}$ (este medio es suministrado por el fabricante). El vial se mantuvo en agitación rotacional a $37^{\circ} \mathrm{C}$ y $225 \mathrm{rpm}$ durante una hora y a continuación distintas cantidades del medio con las bacterias se pipetearon en placas Petri con medio LB Agar (Sigma) suplementado con ampicilina. Todos los plásmidos portaban el gen de resistencia a ampicilina, de manera que solo aquellas bacterias transformadas eran capaces de sobrevivir. Las bacterias se hicieron crecer en una estufa a $37^{\circ} \mathrm{C}$ durante una noche. A continuación se seleccionaron colonias individuales que se hicieron crecer a $37^{\circ} \mathrm{C}$ en medio LB Broth líquido (Sigma) en agitación durante una noche a $225 \mathrm{rpm}$. De esta manera se obtiene gran cantidad de bacterias que portan el plásmido que nos interesa.

Para extraer el plásmido de las bacterias se procedió al lisado y purificación del mismo utilizando el kit QIAprepr ${ }^{\circledR}$ Spin Miniprep (Qiagen), siguiendo las instrucciones del fabricante. Se midió la concentración del producto final y se realizaron 
las diluciones pertinentes para obtener soluciones de trabajo a una concentración de $0,5 \mathrm{mg} / \mathrm{mL}$.

A partir del plásmido circular se sintetizaron las ribosondas mediante dos pasos. El primer paso consiste en la linealización del plásmido mediante el uso de una enzima de restricción situada en el extremo 3' de la secuencia a sintetizar. Para ello se incubaron $10 \mu \mathrm{L}$ de plásmido, $4 \mu \mathrm{L}$ del tampón correspondiente a la enzima de restricción, $2 \mu \mathrm{L}$ de enzima de restricción (Cuadro 3.4) y $4 \mu \mathrm{L}$ de agua ultrapura, durante dos horas en un baño a $37^{\circ} \mathrm{C}$. El resultado de la reacción se purificó con el kit QIAquick ${ }^{\circledR}$ PCR purification Kit (Qiagen), utilizando las instrucciones del fabricante. Una pequeña cantidad del producto obtenido se corrió en un gel de agarosa al $1 \%$ para comprobar la correcta linealización.

Tras la linealización se procedió a la síntesis de las ribosondas mediante una incubación de $5 \mu \mathrm{L}$ del plásmido lineal, $2 \mu \mathrm{L}$ de nucleótidos marcados con digoxigenina (Roche), $1 \mu \mathrm{L}$ de inhibidor de RNasas (Promega), $5 \mu \mathrm{L}$ de tampón (Promega), $1 \mu \mathrm{L}$ de DTT (ditiotreitol, Promega), $1 \mu \mathrm{L}$ de ARN polimerasa (Promega) (Cuadro 3.4) y $5 \mu \mathrm{L}$ de agua ultrapura, durante dos horas en un baño a $37^{\circ} \mathrm{C}$. Para eliminar el ADN lineal que no servía, el producto resultante de la utilización del kit fue tratado con DNasa [20 $\mu \mathrm{L}$ de mezcla; $1 \mu \mathrm{L}$ de DNasa I (Roche); $3 \mu \mathrm{L}$ de tampón] durante 15 minutos a $37^{\circ} \mathrm{C}$. La reacción se detuvo añadiendo $1 \mu \mathrm{L}$ de EDTA (Ácido etilendiaminotetraacético) $0,5 \mathrm{M}$ y calentando la solución 10 minutos a $75^{\circ} \mathrm{C}$.

Por último, para purificar la ribosonda se añadieron $75 \mu \mathrm{L}$ de agua ultrapura, $200 \mu \mathrm{L}$ de etanol puro frío y $10 \mu \mathrm{L}$ de $\mathrm{LiCl} 4 \mathrm{M}$ y la solución se mantuvo a $-20^{\circ} \mathrm{C}$ durante una noche. Al día siguiente las soluciones se centrifugaron a $13000 \mathrm{rpm}$ a $4^{\circ} \mathrm{C}$ durante 15 minutos. Tras la centrifugación se retira el sobrenadante y el pellet visible se resuspende en $25 \mu \mathrm{L}$ de solución de hibridación (ver composición en el apartado de "protocolo de hibridación in situ") y se mantiene a $-80^{\circ} \mathrm{C}$ hasta su uso.

\begin{tabular}{|c|c|c|}
\hline Sonda & Enzima restricción & RNA polimerasa \\
\hline Islet1 & XbaI & T3 \\
\hline Shh & HindIII & T7 \\
\hline Nestina & XhoI & T7 \\
\hline
\end{tabular}

Cuadro 3.4: Enzimas de restricción y RNA polimerasas para cada una de las sondas utilizadas 


\subsubsection{Diseño de la sonda de nestina}

Para sintetizar la sonda de nestina se extrajo el ARN de embriones de 48 horas post fecundación, asegurándonos así que ese gen estaba activo en ese estadio (Mahler y Driever, 2007). La extracción se realizó utilizando 60 embriones que se homogeneizaron mecánicamente en $500 \mu \mathrm{L}$ de Trizol (Ambion, Life Technology). Tras incubar durante 10 minutos, se añadieron $100 \mu \mathrm{L}$ de cloroformo, se agitó y se dejó reposar 3 minutos. El siguiente paso fue centrifugar el contenido a $12000 \mathrm{rpm}$ durante 15 minutos a $4{ }^{\circ} \mathrm{C}$ obteniendo tres fases, de las que nos quedamos únicamente con la fase acuosa. Añadimos $250 \mu \mathrm{L}$ de isopropanol y se incubó durante 10 minutos a temperatura ambiente. Luego se volvió a centrifugar a $12000 \mathrm{rpm}$ durante 10 minutos a $4{ }^{\circ} \mathrm{C}$, eliminando el sobrenadante y resuspendiendo el pellet en 500 $\mu \mathrm{L}$ de etanol al $70 \%$. Se procedió a realizar una última centrifugación a $7000 \mathrm{rpm}$ durante 5 minutos a $4{ }^{\circ} \mathrm{C}$, eliminando el sobrenadante y dejando secar los tubos completamente. El pellet seco se resuspendió en $20 \mu \mathrm{L}$ de agua MilliQ autoclavada. La concentración del ARN se midió en el NanoPhotometer (Bionova).

Con el ARN obtenido se realizó una retrotranscripción para sintetizar una copia de ADN. Este paso se realizó según las instrucciones del kit Applied Byosistems High-capacity cDNA Archive. Una vez obtenido el ADN se realizó una transcripción con el kit GO-Tag Polymerase y los primers diseñados según Mahler y Driever (2007) (5'-GTACCAGATGCTAGAGCTGAACCACCGCCTTG y 3'GCATCTGCCTCTTGATCCTCGTGCTCTCCAG). Se realizó un protocolo de 2 minutos a $95{ }^{\circ} \mathrm{C}, 35$ ciclos de un minuto a $95{ }^{\circ} \mathrm{C}$, un minuto a $65^{\circ} \mathrm{C}$ y un minuto a $72{ }^{\circ} \mathrm{C}$, terminando con siete minutos a $72{ }^{\circ} \mathrm{C}$.

Posteriormente, tras comprobar el peso molecular de las copias obtenidas corriendo un gel de agarosa al 1,5\% y extraer de nuevo el ADN con el kit QuiaQuick Gel Extraction Kit (Quiagen), se subclonó el producto en el plásmido pCRß2.1TOPO (Invitrogen) incubando durante 30 minutos a temperatura ambiente $4,5 \mu \mathrm{L}$ de $\mathrm{ADN}, 0,5 \mu \mathrm{L}$ del vector y $1 \mu \mathrm{L}$ de la solución salina que acompaña al vector.

El plásmido se amplificó y se purificó según lo indicado anteriormente para el resto de plásmidos. Para comprobar que la sonda se había subclonado correctamente, en vez de pasar directamente a la síntesis de las ribosondas, se realizó un procedimiento con las enzimas de transcripción EcoRI para comprobar la inserción y con 
3.7. Hibridación in situ

XhoI para comprobar la orientación. Una vez seleccionadas las bacterias que tenían el plásmido en la orientación correcta (tanto las antisentido como las sentido para los controles), se procedió a la síntesis tal y como se ha especificado para el resto de sondas.

\subsubsection{Protocolo de hibridación in situ}

Dado que se trabaja con ARN, para eliminar en la medida de lo posible las ARNasas todos los líquidos fueron autoclavados, y los materiales de vidrios horneados toda la noche a $200^{\circ} \mathrm{C}$. Las secciones destinadas a la realización de esta técnica se recogieron en portaobjetos Superfrost Ultra Plus (Thermo Scientific) y se conservaron a $-80^{\circ} \mathrm{C}$.

Para rehidratar el tejido se utilizó una batería de alcoholes de concentración decreciente $(100 \%, 95 \%, 70 \%, 50 \%)$, incubando por último el tejido dos veces durante un minuto en tampón citrato sódico salino (SSC 2x). Para eliminar las proteínas unidas a los ácidos nucleicos se realizó un tratamiento con Proteinasa $\mathrm{K}$ (Sigma) a $37^{\circ} \mathrm{C}$ durante 5 minutos, tras lo cual se lavaron las secciones en agua destilada. El siguiente paso consistió en una acetilación preincubando las secciones en tampón trietanolamina $0,1 \mathrm{M}$ a $\mathrm{pH} 8$ durante 3 minutos seguido por una incubación de 10 minutos en el mismo tampón con anhídrido acético 2,5\% (Panreac). Después los tejidos se deshidrataron en una batería de alcohol de concentración creciente, y se dejaron secar a temperatura ambiente durante una hora. El medio de hibridación se tomó de Barthel y Raymond (1993) y se compone de $1 \%$ tampón Tris- $\mathrm{HCl} \mathrm{pH}$ 7,5; $6 \%$ de $\mathrm{NaCl}$ 5M; 0,2\% de EDTA 0,5M; $50 \%$ de formamida (Sigma); $20 \%$ de sulfato de dextrano (Sigma) y 0,01\% de solución de bloqueo (Roche). La sonda, a una concentración de 1:100, se preincubó con dicho medio durante 5 minutos a $68^{\circ} \mathrm{C}$ tras lo cual se incubaron los portaobjetos con esta solución durante toda la noche a $68^{\circ} \mathrm{C}$ en una cámara húmeda con un cubreobjetos (Fig. 3.6).

$\mathrm{Al}$ día siguiente las secciones de lavaron dos veces durante 30 minutos en SSC 2x para retirar los cubreobjetos y otra media hora a $65^{\circ} \mathrm{C}$ en una solución de formamida al $50 \%$. Para eliminar los restos de formamida se lavaron dos veces con SSC 2x a $37^{\circ} \mathrm{C}$. Posteriormente se trataron las secciones con ARNasa A $(0,02 \mathrm{mg} / \mathrm{mL})$ en un tampón formado por $10 \%$ de $\mathrm{NaCl} 5 \mathrm{M}, 1 \%$ de tampón TrisHCl pH 7,5 y 0,2\% de 
EDTA $0,5 \mathrm{M}$ durante 30 minutos a $37^{\circ} \mathrm{C}$, seguido de otra incubación de media hora a $65^{\circ} \mathrm{C}$ en el tampón sin ARNasa. Las secciones se lavaron durante 2-3 horas en SSC 2X, 0,05\% Triton X-100 y 0,002\% de solución de bloqueo y luego dos veces durante

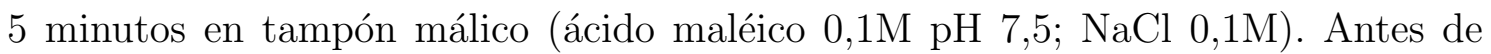
incubar con el anticuerpo primario se preincubaron las secciones con un 0,01\% de solución de bloqueo y 0,003\% de Triton X-100 en tampón málico. El anticuerpo anti-digoxigenina conjugado con fosfatasa alcalina se diluyó a 1:3000 y se incubaron las secciones durante toda la noche a $4^{\circ} \mathrm{C}$ (Fig. 3.6).

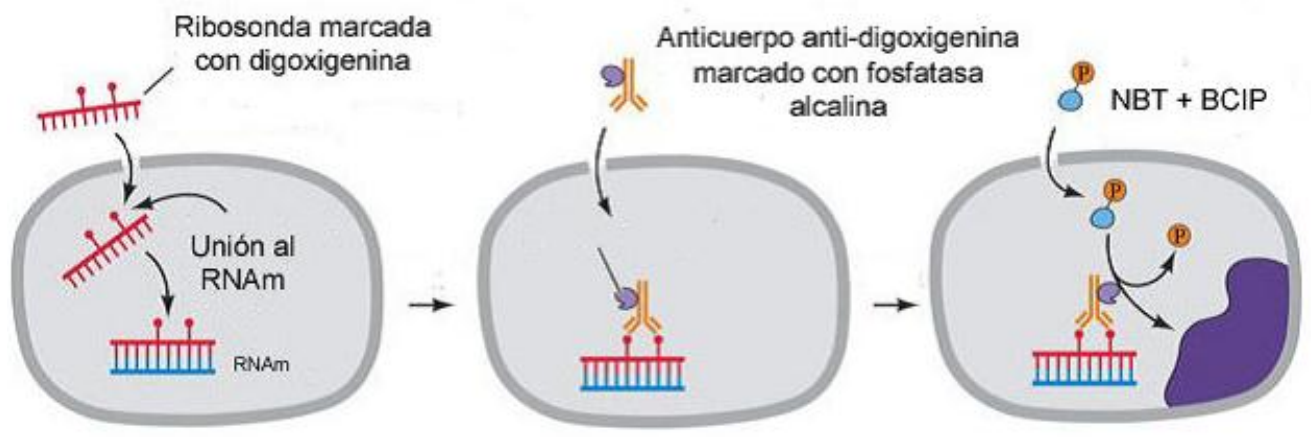

Figura 3.6: Esquema de la técnica de la hibridación in situ revelada con fosfatasa alcalina

Para el revelado, los portaobjetos se lavaron en tampón málico tres veces y dos en la solución de revelado (Tris HCL pH 9,5 0,1M; MgCl2 50mM; NaCl 0,1M; Triton $\mathrm{X}-100$ 0,1\%). Las secciones se incubaron con un mililitro de la solución al que se añaden 3,5 $\mu \mathrm{L}$ de BCIP (5-bromo-4 cloro-3 indol fosfato) y $1 \mu \mathrm{L}$ de NBT (azul de nitrotetrazolio) (Fig. 3.6). La reacción se controló bajo la lupa y se lavaron las secciones en tampón fosfato. Para su conservación los portaobjetos se deshidrataron en una batería creciente de alcoholes y xilol, y se montaron con Entellan (Merck).

\subsubsection{Controles de la técnica de hibridación in situ}

Para comprobar la especificidad de dicha técnica realizamos los siguientes controles negativos:

1. Omisión de la ribosonda correspondiente, para comprobar que el anticuerpo anti-digoxigenina se une específicamente.

2. Eliminación del anticuerpo anti-digoxigenina conjugado con fosfatasa alcalina. 
3. Realización de la técnica utilizando sondas sentido.

En ninguno de los casos se obtuvo marcaje, excepto un ligero marcaje de los fotorreceptores con la sonda de Shh.

\subsection{Análisis de imagen}

Se obtuvieron imágenes de las distintas preparaciones utilizando un fotomicroscopio (Olympus Provis AX70, Japón) equipado con campo claro y epifluorescencia, conectado a una cámara digital (Olympus DP70). Las imágenes fueron capturadas con el programa MicroCCD.

Para obtener las imágenes de los cultivos primarios se utilizó un microscopio invertido Leica DMI3000 B, equipado con una cámara DFC300 FX. Las imágenes de las técnicas inmunocitoquímicas sobre cultivos se tomaron en un microscopio confocal (Leica) capturadas con el programa Leica Confocal Software. La medición del diámetro de las esferas se realizó con el programa Image J (Java).

Para la elaboración de la iconografía las imágenes fueron optimizadas mediante el programa informático Adobe Photoshop CS (Adobe Systems Inc., San Jose, CA, EE.UU.), con la ayuda del programa Image J (Java) para las imágenes tomadas con el confocal.

\subsection{Análisis estadístico}

Para realizar los diferentes análisis estadísticos utilizamos el programa Microsoft Office Excel 2007. El primer análisis fue un test de ANOVA de un factor, comparando todos los grupos entre sí. Si el nivel de significación era menor de 0,05, se hicieron pruebas por pares de grupos, con un test t de Student para datos apareados. 
3. Material y métodos 
Capítulo 4

Resultados 
4. Resultados 


\subsection{Detección de células mitóticamente activas}

Para la detección de células progenitoras de retina adulta hemos utilizado la bromo-desoxi-uridina (BrdU) inyectada intraperitonealmente. La BrdU es un análogo de la timidina que se incorpora al $\mathrm{ADN}$ en la fase $\mathrm{S}$ del ciclo celular, marcando así todas las células que se han dividido durante el tiempo de exposición. Con el fin de marcar todos los progenitores del linaje de bastones, se realiza un tratamiento que marca también las células con menor tasa proliferativa.

Las diferentes formas de administración en peces teleósteos incluyen desde la disolución del producto en el agua del acuario (Otteson et al., 2001; Hitchcock y Kakuk-Atkins, 2004), la inyección intraocular (Stenkamp et al., 1997; Wu et al., 2001) o la inyección intraperitoneal (Santamaria et al., 1996; Mack et al., 2003; Takeda et al., 2008; Sánchez-González, 2009). De los tres métodos, hemos elegido el de la inyección intraperitoneal, principalmente porque permite controlar la concentración de BrdU inyectada y evita posibles daños en la retina.

Partiendo del protocolo puesto a punto en nuestro laboratorio para carpines (Sánchez-González, 2009), hemos hecho las adaptaciones oportunas para su utilización en peces cebra. Así, se inyectaron cuatro dosis de 0,03 mL de una solución de $30 \mathrm{mg} / \mathrm{mL}$ de BrdU en días alternos. Al octavo día, se extrajeron los ojos y se prepararon para su estudio histológico. Para el estudio a largo plazo de los progenitores retinianos se realizó una única inyección y se dejó pasar el tiempo previsto para cada uno de los grupos experimentales (30 minutos, 2 y 4 horas, 1, 7, 14, 21 y 28 días).

\subsubsection{Localización de células en división}

Una vez obtenidas las secciones, se realizaron técnicas inmunohistoquímicas mediante el método de la avidina-biotina-peroxidasa (ABC) y el método inmunofluorescente. Las células positivas para BrdU, que hubieran incorporado este marcador a su ADN mientras duró el tratamiento, se encuentran tanto en la zona periférica germinal como en la retina central. Debido a que el procesamiento para la detección de BrdU incluye una inmersión en $\mathrm{HCl}$, en las imágenes, muchos de los núcleos aparecen dañados. 


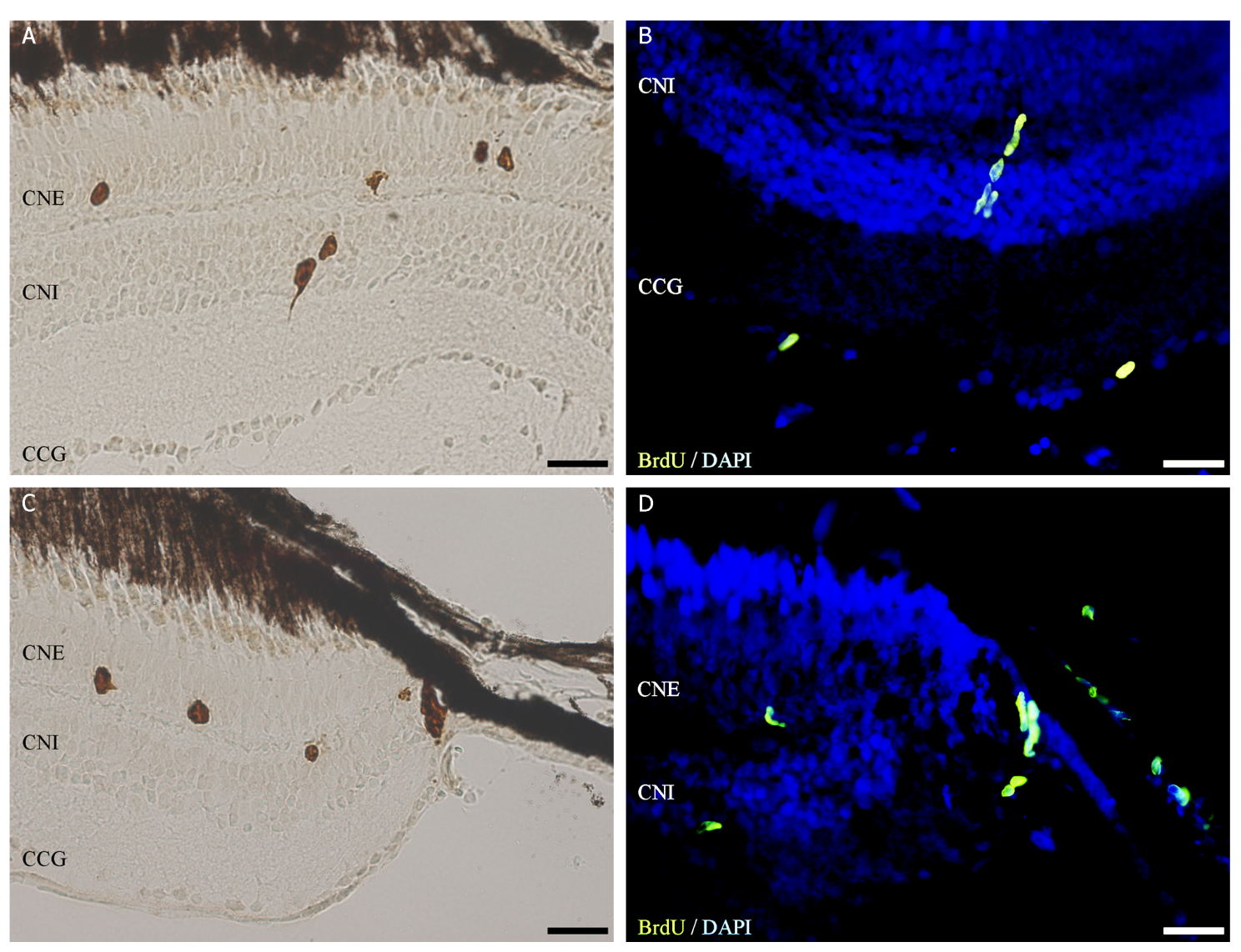

Figura 4.1: Inmunohistoquímica para BrdU con los métodos $\mathrm{ABC}$ (A y $\mathrm{C}$ ) e inmunofluorescencia ( $\mathbf{B}$ y $\mathbf{D})$. Las células que se han dividido y por tanto han incorporado BrdU se encuentran en la retina central (A y B), donde hay células en todas las capas, tanto en las nucleares, como en las plexiformes. En la ZPG (C y D) se observa un grupo de células positivas para BrdU. Barra de escala: $20 \mu \mathrm{m}$.

En la retina central se observan células positivas a BrdU en todas las capas, pero se encuentran mayoritariamente en la CNE, en la CPE y en la CNI, siendo en esta última donde hay menor número de células positivas (Fig. $4.1 \mathrm{~A}$ y B). El número de células positivas para BrdU es mucho menor en la CPI y en la CCG, aunque se pueden encontrar en ellas algunos núcleos positivos. También encontramos algunas células que se han dividido en la CFNO. Las células positivas en la CNE y la CPE suelen aparecer en grupos, probablemente porque migran conjuntamente (Fig. 4.1 A y B).

En la región periférica de la retina del pez cebra es difícil diferenciar la zona de transición y la ZPG (Fig. 4.1 C y D), que sí se diferencia con relativa facilidad en otras especies de teleósteos como la trucha (Olson et al., 1999) o el carpín (Sánchez- 
4.1. Detección de células mitóticamente activas

González, 2009), donde la ZPG es más extensa. En dicha zona observamos un grupo de células fusiformes, de número y tamaño variado, marcadas con BrdU.

\subsubsection{Estudio de los progenitores a largo plazo}

Hemos realizado un estudio cuantitativo de los progenitores retinianos en el pez cebra adulto a lo largo del tiempo. Para ello, tras inyectar BrdU una única vez a los peces, extrajimos sus ojos a distintos tiempos post-inyección (30 minutos, 2 y 4 horas, 1, 7, 14, 21 y 28 días). Para cada uno de los tiempos analizamos al menos tres ejemplares, y tras realizar la técnica inmunohistoquímica revelada con el método ABC (Fig. 4.2, fig. 4.3 y fig. 4.4), contamos el número de células positivas para BrdU (Fig. 4.5). Dado que las células positivas a BrdU que se consideran progenitores retinianos se encuentran en la ZPG, la CNI y la CNE, excluimos del conteo las células que se localizan en otras capas de la retina.

En la retina central, teniendo en cuenta la suma de las células positivas a BrdU de la CNI y la CNE (Fig. 4.5 A), hay un aumento en el número de células hasta un día post inyección. A partir de ese momento se observa un descenso del número. Tan sólo 30 minutos tras la inyección ya vemos células marcadas con BrdU, y éstas se detectan al menos hasta el día 28. Teniendo en cuenta que el tiempo del metabolismo de la BrdU son dos horas, podemos deducir que el aumento que se produce hasta el día 1, es debido a la incorporación de BrdU en las células que se dividen durante ese período. El descenso que se observa en los días posteriores se debe a que las sucesivas divisiones celulares llevan consigo una dilución del producto y una reducción del número de células con una cantidad detectable de marcaje.

En la ZPG (Fig. 4.5 B) el resultado es similar. Se observa marcaje en todos los grupos experimentales, y el mayor número de células positivas se ve un día tras la inyección. En esta región hay menor diferencia en el número de células marcadas entre las 2 y 4 horas y entre los 14 y 21 días con respecto a la retina central.

En la capa nuclear interna (Fig. 4.5 C), en general, el número de células positivas es menor que en otras capas, probablemente porque las células en la CNI se dividen más lentamente. A los 28 días no hemos encontrado ninguna célula positiva para BrdU. Las células positivas a BrdU que observamos en la retina central son células 
que se han dividido en la CNI en un tiempo anterior y que han migrado a la CNE, donde se han vuelto a dividir.

En la figura 4.5 D se muestra un resumen de la evolución de las células progenitoras a lo largo del tiempo. Es de destacar la relación entre las células que han incorporado BrdU en la retina central y en la ZPG. En los tiempos postinyección más bajos analizados hay más células positivas en la ZPG que en la retina central. A las 4 horas la diferencia es mínima, y un día tras la inyección hay más células positivas en la retina central que en la ZPG. Esto se invierte a los 7 días y se estabiliza a partir de ese periodo. Las diferencias entre ambas poblaciones están relacionadas con la tasa de división de cada una. 

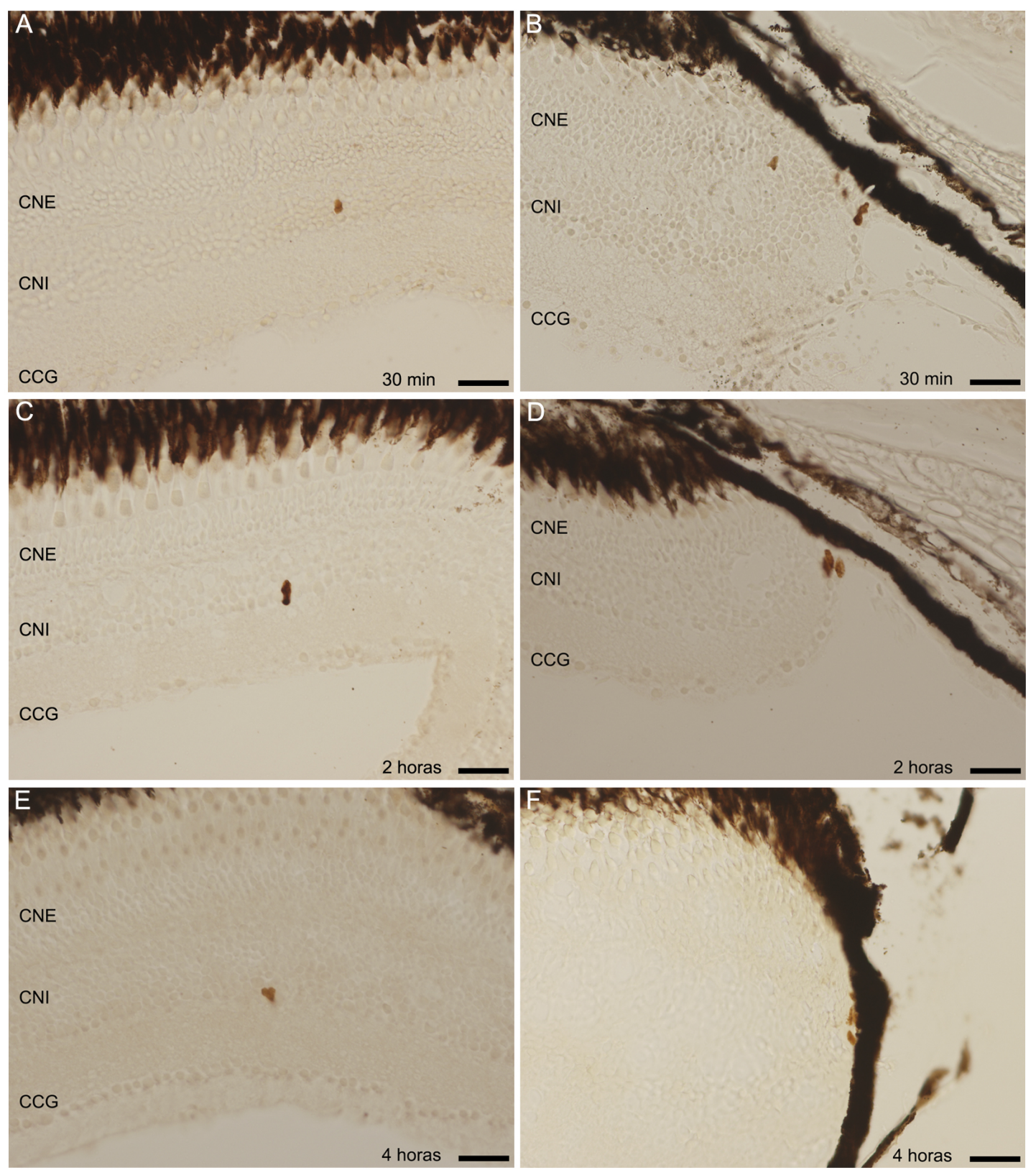

Figura 4.2: Inmunohistoquímica para BrdU revelada con el método ABC a distintos tiempos tras una única inyección de $30 \mathrm{mg} / \mathrm{mL}$. Los distintos tiempos estudiados son 30 minutos (A y B), 2 horas (C y D) y 4 horas (E y F). Para cada uno de los tiempos se han tomado fotos de la retina central (A, C y E) y la ZPG (B, D y F). Barra de escala: $20 \mu \mathrm{m}$. 

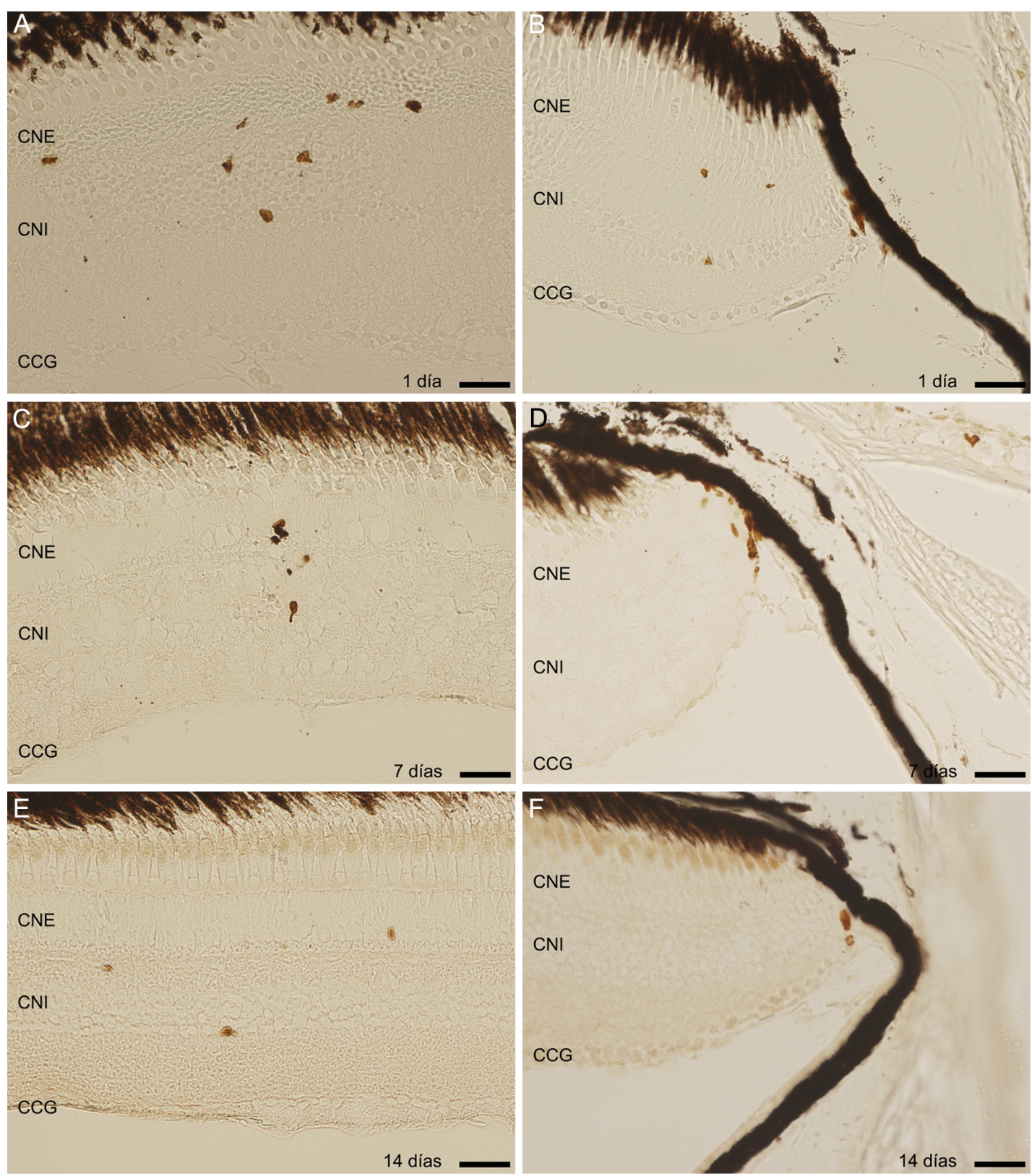

Figura 4.3: Inmunohistoquímica para BrdU revelada con el método $\mathrm{ABC}$ a distintos tiempos tras una única inyección de $30 \mathrm{mg} / \mathrm{mL}$. Los distintos tiempos estudiados son 1 día (A y B), 7 días (C y D) y 14 días (E y F). Para cada uno de los tiempos se han tomado fotos de la retina central (A, C y E) y la ZPG (B, D y F). Barra de escala: $20 \mu \mathrm{m}$. 

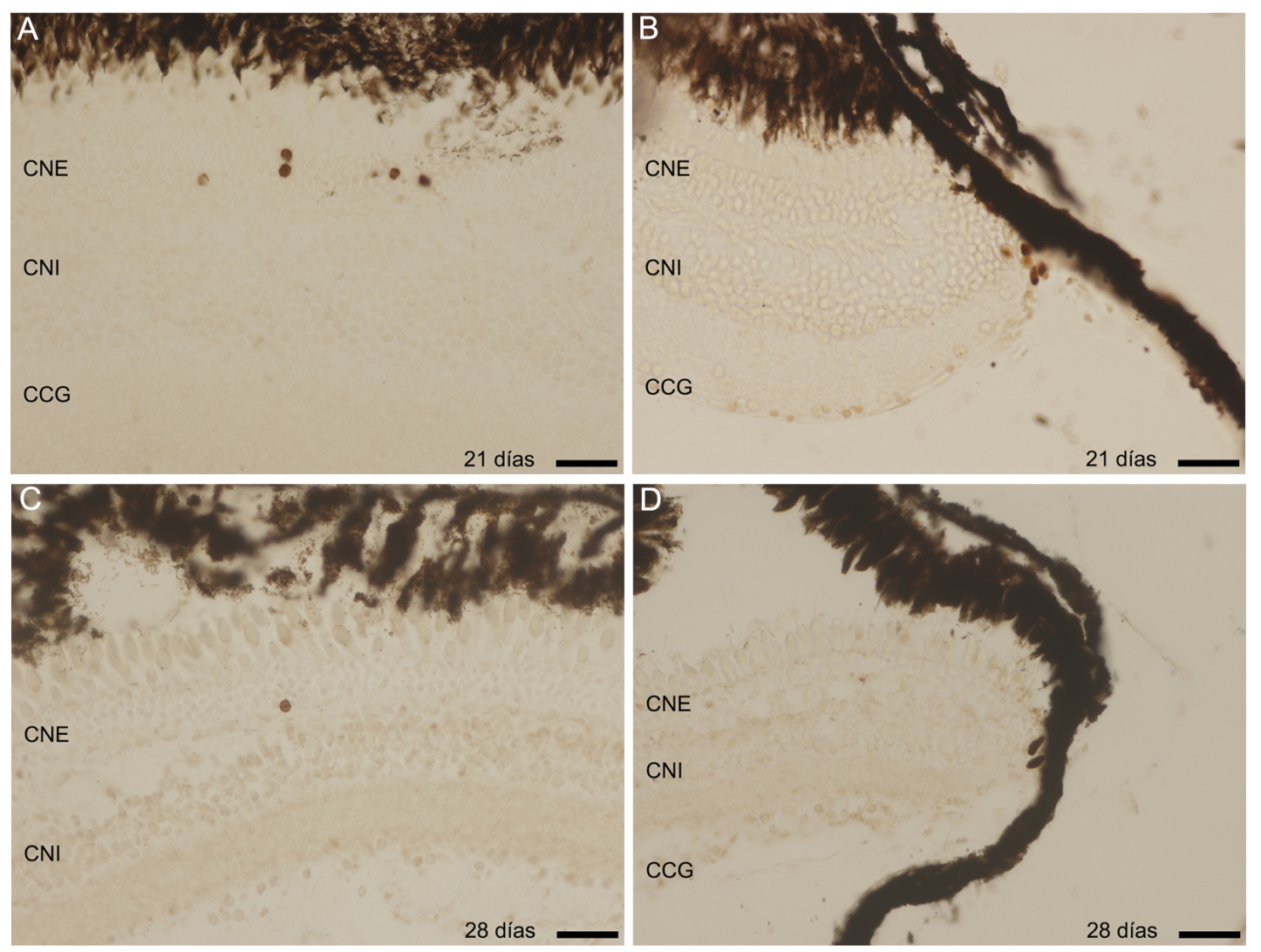

Figura 4.4: Inmunohistoquímica para BrdU revelada con el método ABC, a distintos tiempos tras una única inyección de $30 \mathrm{mg} / \mathrm{mL}$ de BrdU. Los distintos tiempos estudiados son 21 días (A y B) y 28 días (C y D). Para cada uno de los tiempos se han tomado fotos de la retina central (A y C) y la ZPG (B y D). Barra de escala: 20 $\mu \mathrm{m}$. 


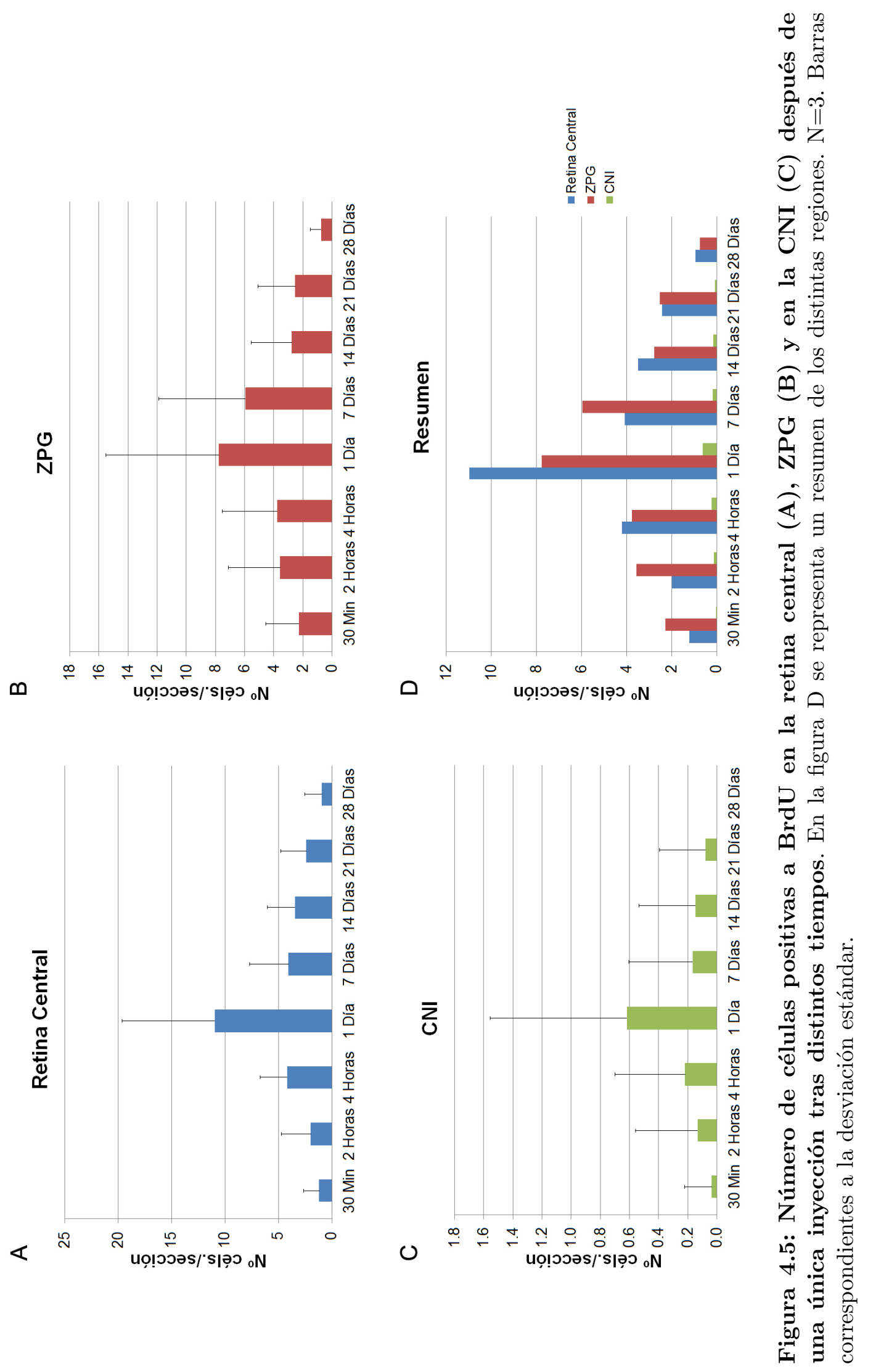


4.2. Inmunorreactividad para marcadores neurales en la retina madura

\subsection{Inmunorreactividad para marcadores neura- les en la retina madura}

Con el fin de analizar las propiedades neuroquímicas de las células progenitoras de la retina, hemos estudiado los patrones de expresión de tres marcadores neurales mediante técnicas inmunohistoquímicas (Prox1, Pax6 y Sox2) en la retina central y en la ZPG, tanto por el método ABC como por inmunofluorescencia, y su colocalización con BrdU. En todas las imágenes obtenidas por inmunofluorescencia, el marcador neural aparece en rojo, la BrdU en verde, y DAPI, como marcador nuclear, en azul.

\subsubsection{Prox 1}

Localización de células positivas a Prox1 en la retina

El factor de transcripción Prox1 se expresa en células de la CNI y de la CCG de la retina del pez cebra (Fig. 4.6). En la CNI, se distingue marcaje para Prox1 en las células horizontales con los somas ovalados o alargados (Fig. 4.6 A y C). En la CNI vemos mayor número de células positivas en la zona más vitreal, aunque hay células positivas en todo el grosor de la capa. Las células más intensamente marcadas son las localizadas en la CCG, son células grandes y redondeadas que forman una única fila (Fig. 4.6). Esporádicamente vemos células positivas para Prox1 en la CPI (Fig. 4.6 A y $\mathrm{D})$.

En la ZPG hay células positivas a Prox1, observándose tanto células redondeadas como fusiformes (Fig. 4.6 B y E). En esta región periférica de la retina se ven células positivas incluso en la CNE, en lo que sería la zona de transición (Fig. 4.6 E).

\section{Colocalización de Prox1 con BrdU}

Algunas células que han incorporado BrdU en la retina adulta del pez cebra expresan también Prox1. Observamos colocalización de Prox1 y BrdU tanto en la retina central como en la ZPG (Fig. 4.7). 

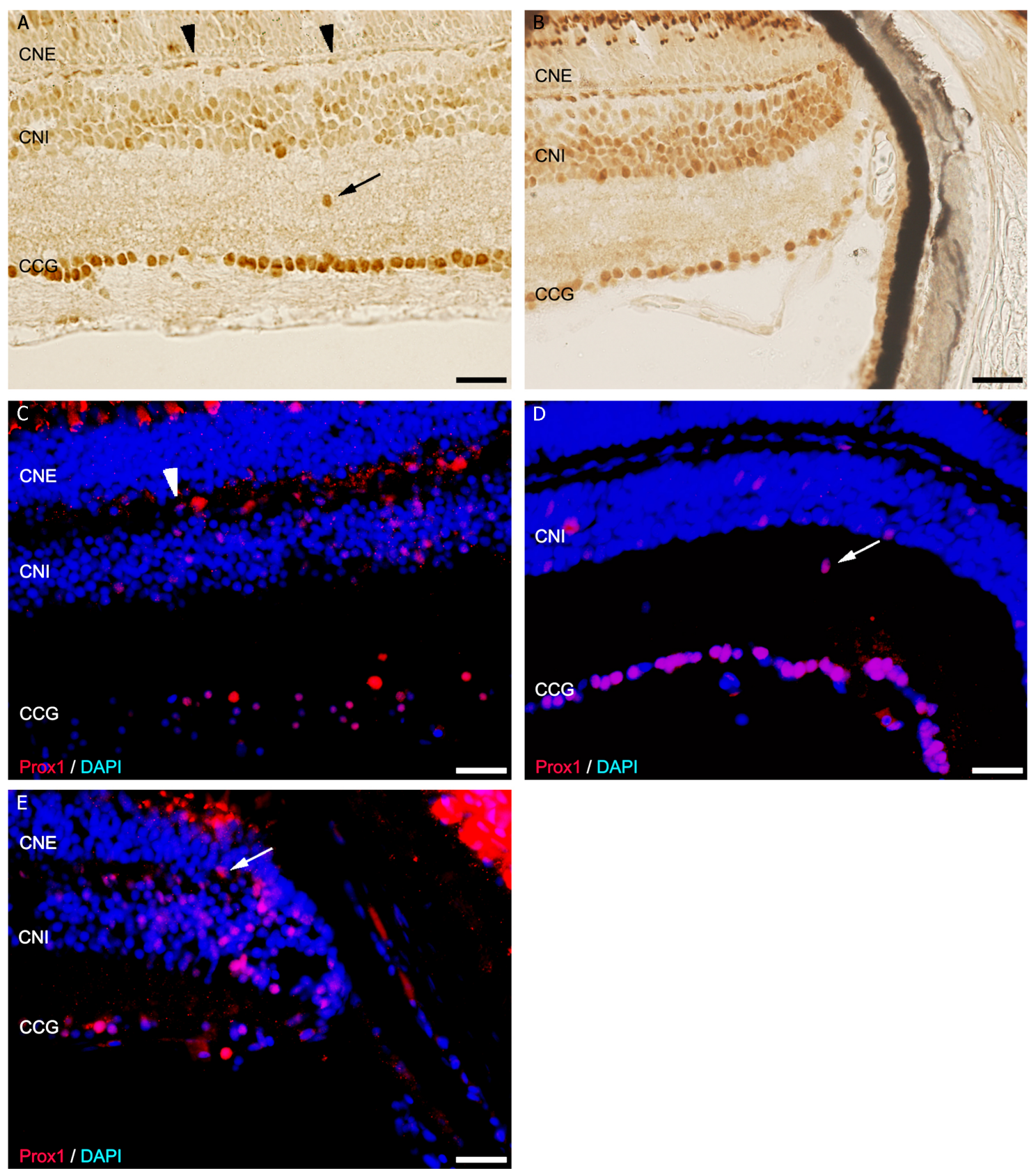

Figura 4.6: Localización de las células Prox1 positivas en la retina del pez cebra marcadas con el método $\mathrm{ABC}(\mathrm{A}$ y $\mathrm{B})$ y con inmunofluorescencia $(\mathrm{C}$, D y E). Hay células Prox1 positivas en la retina central (A, C y D) y en la ZPG (B y E). En la retina central hay células marcadas en la CNI y la CCG. En A y C se observan células horizontales positivas para Prox1 (cabezas de flecha). Hay también algunas células positivas en la CPI (flecha en A y D). En la ZPG las células positivas para Prox1 son principalmente redondeadas (B y E). En esta zona hay también células marcadas en la CNE (E, flecha blanca). Barra de escala: $20 \mu \mathrm{m}$. 
4.2. Inmunorreactividad para marcadores neurales en la retina madura
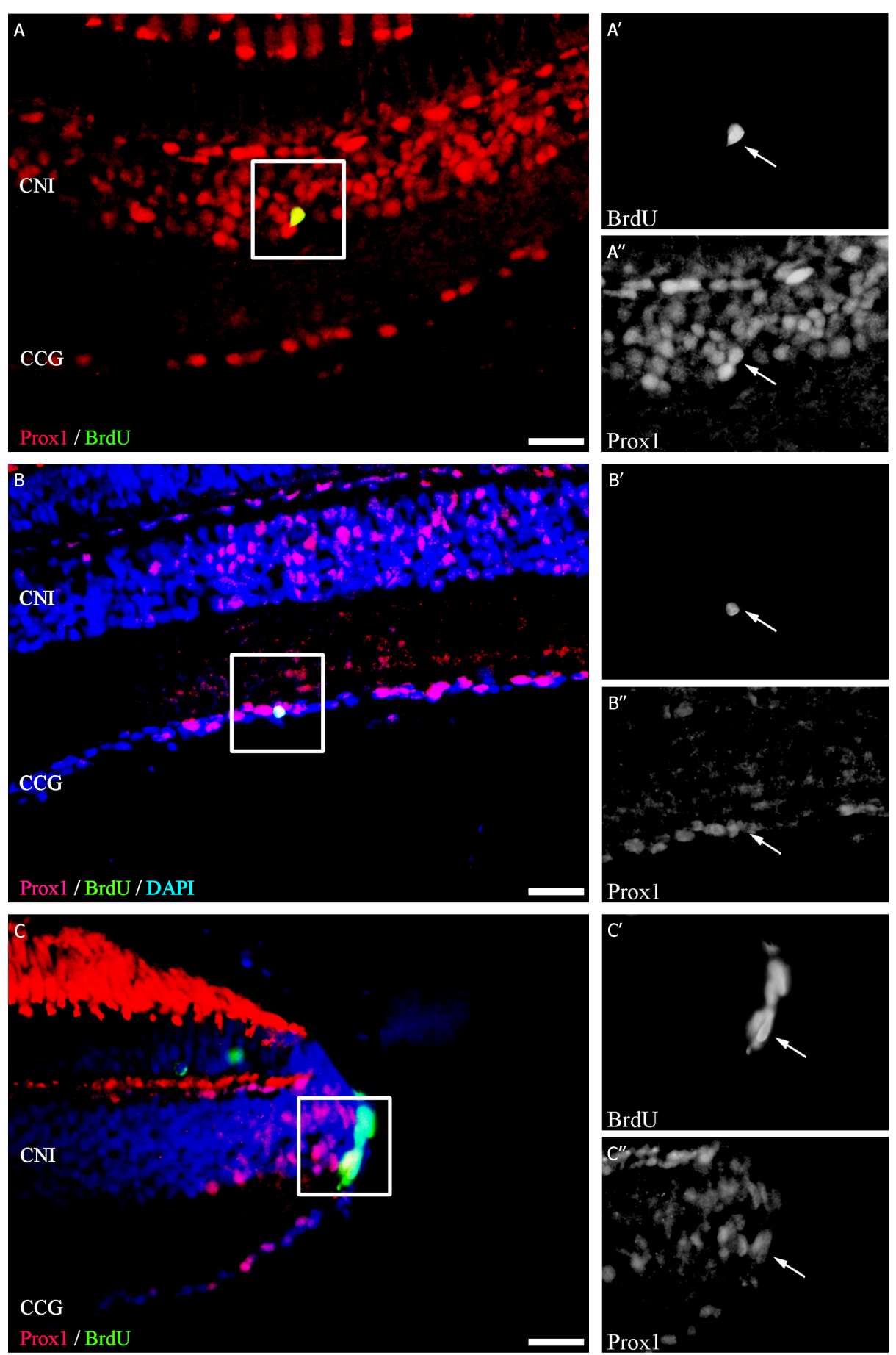

Figura 4.7: Colocalización de Prox1 con BrdU en la retina central (A y B) y en la ZPG (C). Hay células que colocalizan ambos marcadores tanto en la CNI (A) como en la CCG (B). En la ZPG las células que expresan ambos marcadores se encuentran en la zona más externa (C). En todos los casos, a la derecha, marcadas con una flecha se muestran en detalle las células positivas para $\operatorname{BrdU}$ (A', B' y C') y $\operatorname{Prox1}$ (A", B" y C") separando los dos canales y en escala de grises. El marcaje de fotorreceptores es inespecífico, ya que también aparece en controles negativos. Barra de escala: $20 \mu \mathrm{m}$. 
Las células de la retina central doblemente marcadas para Prox1 y BrdU se encuentran principalmente en la CNI (Fig. 4.7 A). Se localizan prácticamente en todo el grosor de la capa y se trata principalmente de células redondeadas. Se observan también, esporádicamente, células positivas para BrdU y para Prox1 en la CCG (Fig. 4.7 B). Son células redondeadas y de gran tamaño.

En la zona periférica se ven también células marcadas para Prox1 y para BrdU (Fig. 4.7 C). Se trata de células con núcleos de morfología principalmente fusiforme, situadas en la zona más externa de la ZPG.

\subsubsection{Pax6}

\section{Localización de células positivas a Pax6 en la retina}

En la retina del pez cebra encontramos células marcadas para Pax6 tanto en la retina central como en la ZPG (Figs. 4.8 y 4.9). En la retina madura hay marcaje en la CNI y en la CCG (Fig. 4.9 A y C). En la CNI las células Pax6 positivas se ven en la zona más próxima a la CPI. Unas son células redondeadas y otras son células más fusiformes. En la CCG las células positivas forman una única capa de células grandes y redondeadas. En ambas capas hay células que presentan gran intensidad de marcaje y otras que tienen un marcaje débil.

En la ZPG observamos células fusiformes y redondeadas marcadas para Pax6, y que presentan diferente intensidad de marcaje (Fig. 4.9 B y D). Estas células se sitúan en la zona más periférica de la ZPG. 


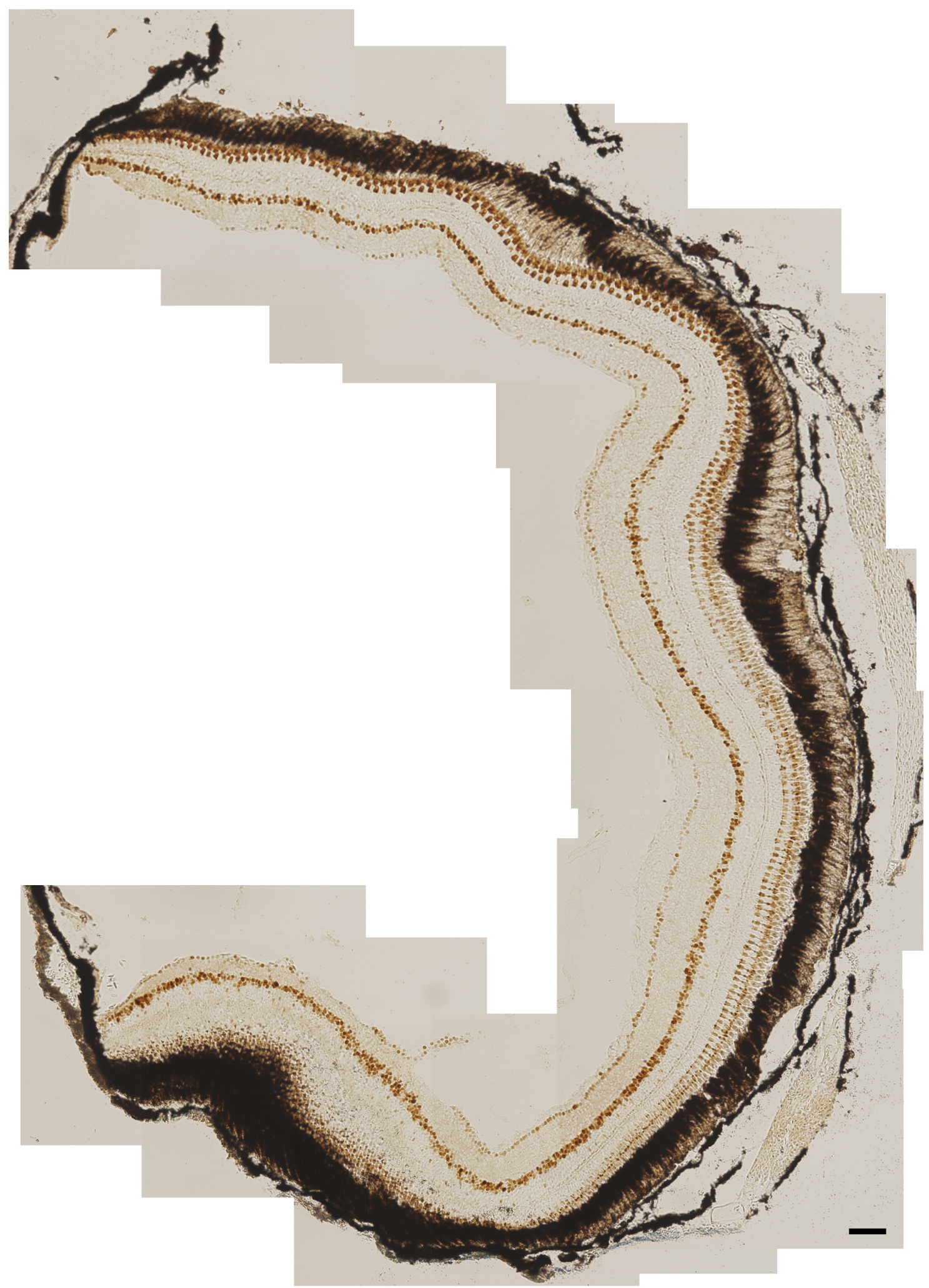

Figura 4.8: Reconstrucción de una retina marcada con Pax6 mediante la técnica de la avidina-biotina peroxidasa. Barra de escala: $30 \mu \mathrm{m}$. 

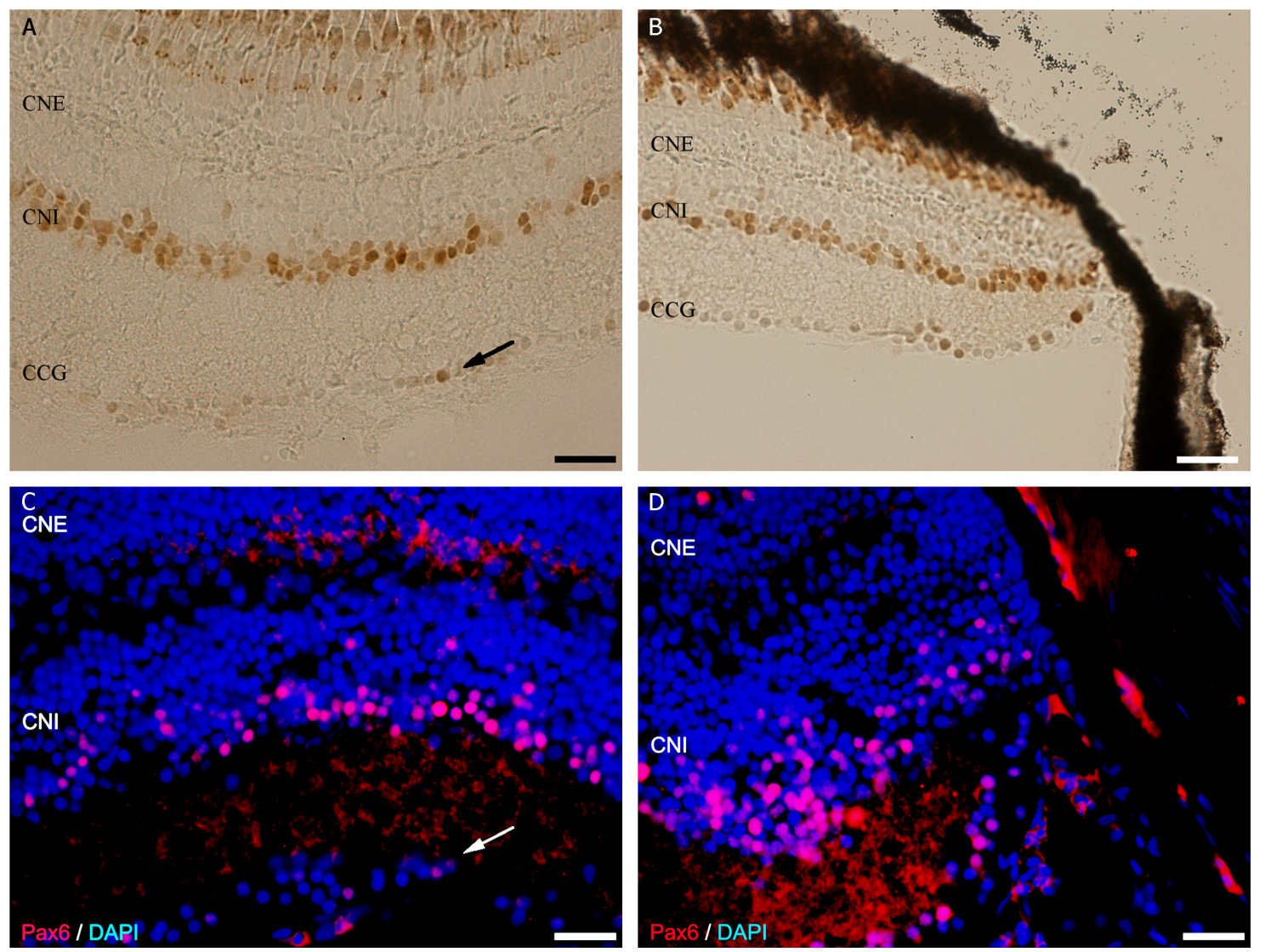

Figura 4.9: Detección de células Pax6 positivas mediante las técnicas inmunohistoquímicas de $\operatorname{ABC}(A, B)$ e inmunofluorescencia $(C, D)$. En la retina central el marcaje se encuentra principalmente en la CNI (A y C), aunque se observan también algunas células marcadas en la CCG (flechas). En la ZPG hay también células marcadas con ambas técnicas (B y D). Barra de escala: $20 \mu \mathrm{m}$. 


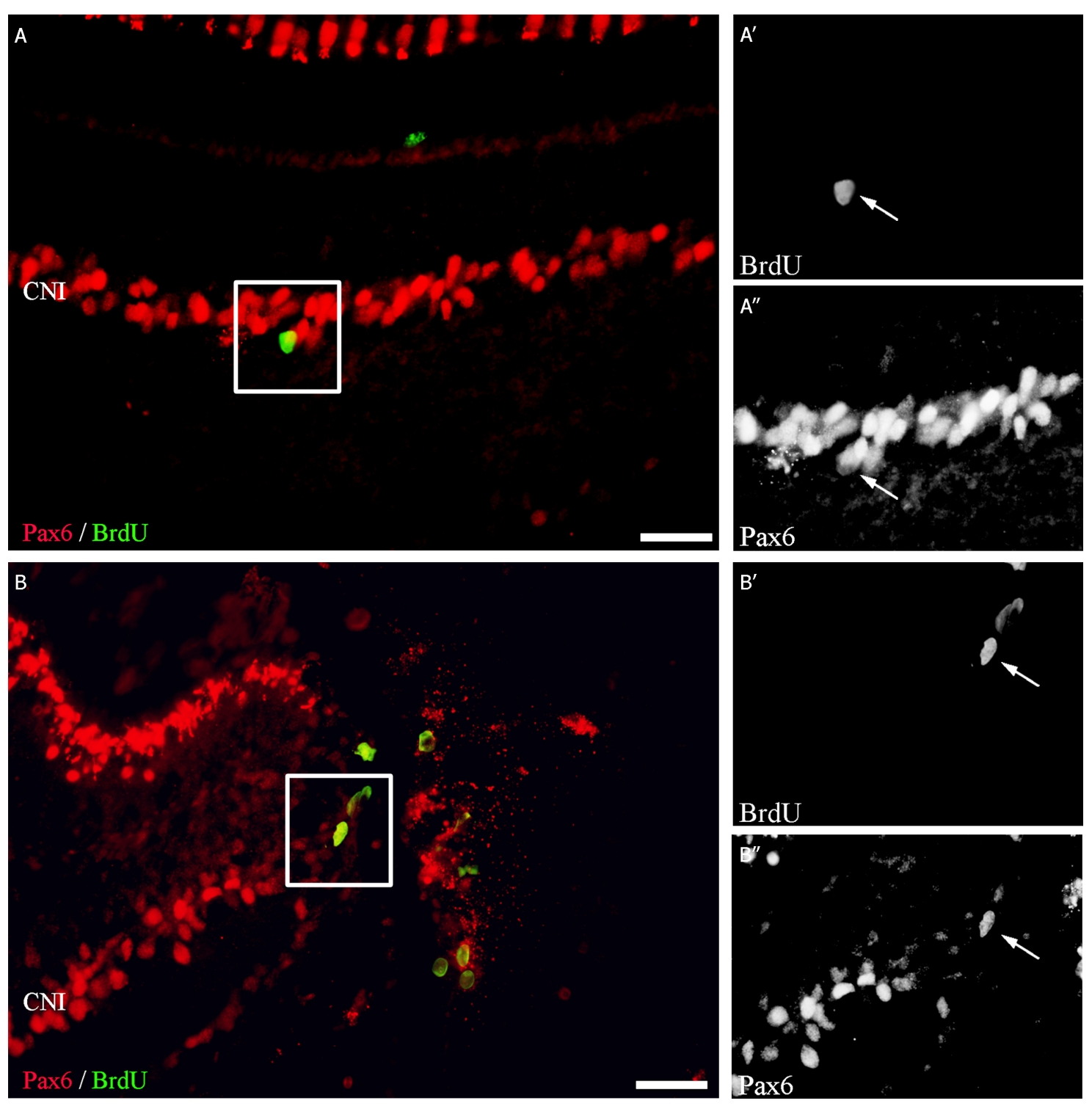

Figura 4.10: Colocalización de Pax6 y BrdU tanto en la retina central (A), como en la ZPG (B). En la retina central Pax6 y BrdU colocalizan en la zona más vitreal de la CNI (A, A' y A"). Las células que expresan ambos marcadores en la ZPG son principalmente alargadas (B, B' y B"). En todos los casos a la derecha marcadas con una flecha se muestran en detalle las células que expresan Pax6 y BrdU separando los dos canales y en escala de grises. Barra de escala: $20 \mu \mathrm{m}$.

\section{Colocalización de Pax6 y BrdU}

En la retina central hay un escaso número de células que colocalizan Pax6 y BrdU (Fig. 4.10 A). Son células de la región más vitreal de la CNI y se corresponden con células redondeadas. En los experimentos realizados no hemos encontrado 
colocalización de ambos marcadores en ninguna otra capa de la retina central.

En la zona periférica encontramos numerosas células positivas para Pax6 que han incorporado BrdU (Fig. 4.10 B). Éstas son de morfología tanto alargada como redondeada.

\subsubsection{Sox 2}

\section{Localización de células positivas a Sox2 en la retina}

En el pez cebra adulto, Sox2 se expresa tanto en la retina central como en la ZPG (Fig. 4.11). Al igual que para Pax6, encontramos células positivas a Sox2 tanto en la CCG como en la CNI (Fig. 4.11 A y C). En la CCG hay células positivas a Sox2 intercaladas con otras que no lo expresan. Son células con núcleos redondeados ,y probablemente, se trata de células amacrinas desplazadas. En la CNI la mayoría de los núcleos marcados son también redondeados y se encuentran en la zona más vitreal. Además, algunas de las células Sox2 positivas tienen un núcleo alargado y están situadas en una zona más central de la CNI. Por su morfología, podrían corresponder a células de Müller. En la ZPG las células positivas para Sox2 tienen núcleos alargados o redondeados (Fig. 4.11 B y D). Se encuentran distribuidas en toda la extensión de la ZPG.

\section{Colocalización de Sox2 y BrdU}

Algunas células positivas a Sox2 lo son también para BrdU tanto en la retina central (Fig. 4.12 A) como en la ZPG (Fig. 4.12 B). En la CNI de la retina central la colocalización de ambos marcadores no es muy frecuente, y cuando se observa es en una fila de células localizadas en la zona media de la CNI. En la ZPG la mayoría de las células expresan ambos marcadores, aunque se observan también algunas células marcadas para cada uno de los dos marcadores por separado. 

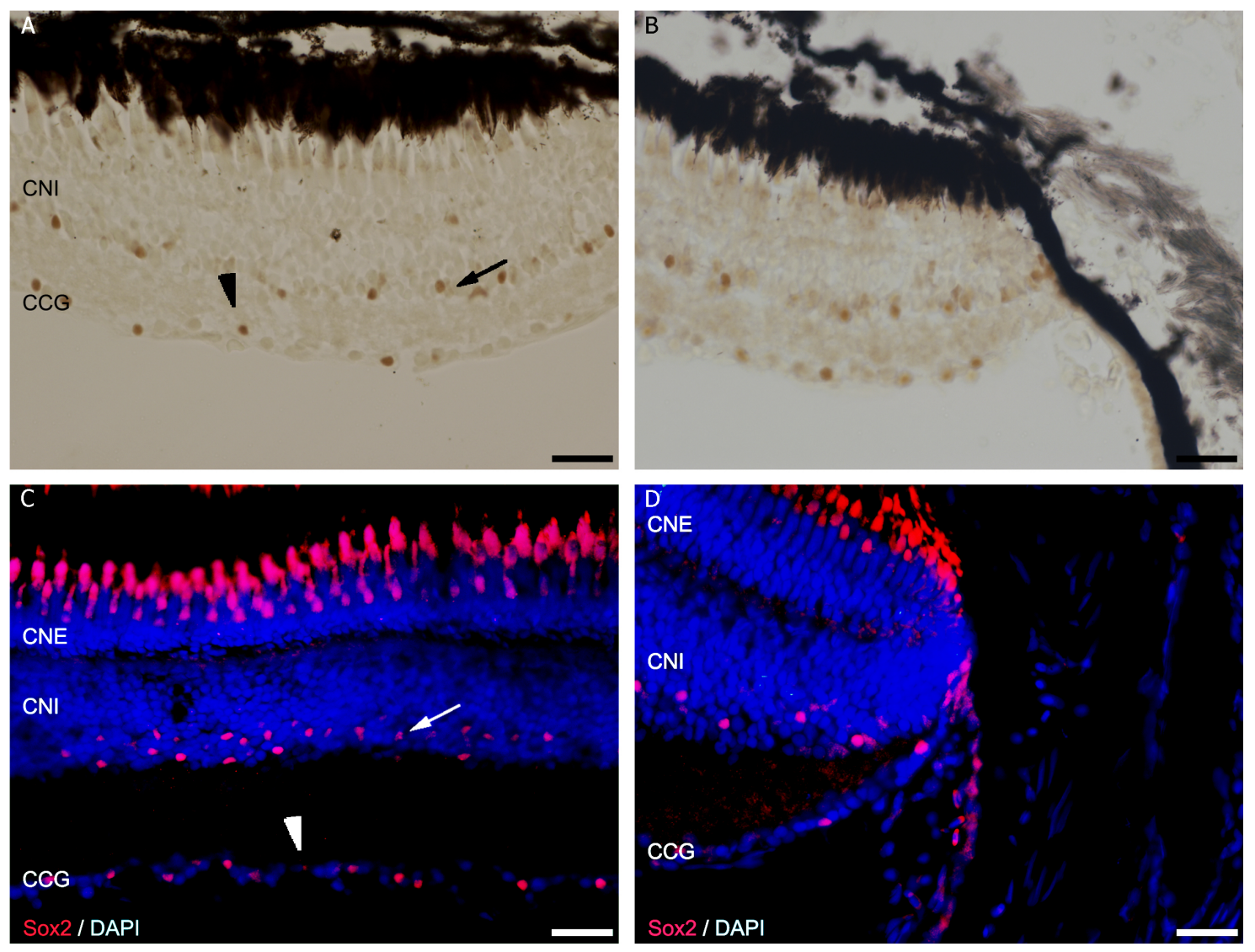

Figura 4.11: Inmunohistoquímica contra Sox2 según el método $\mathrm{ABC}$ (A y $\mathrm{B})$ y el método fluorescente ( $\mathbf{C}$ y $\mathbf{D}$ ). En la retina central (A y C) hay células marcadas en la CCG (puntas de flecha) y en la zona más vitreal de la CNI (flechas). En la ZPG hay también células positivas para Sox2 (B y D). Barra de escala: $20 \mu \mathrm{m}$. 


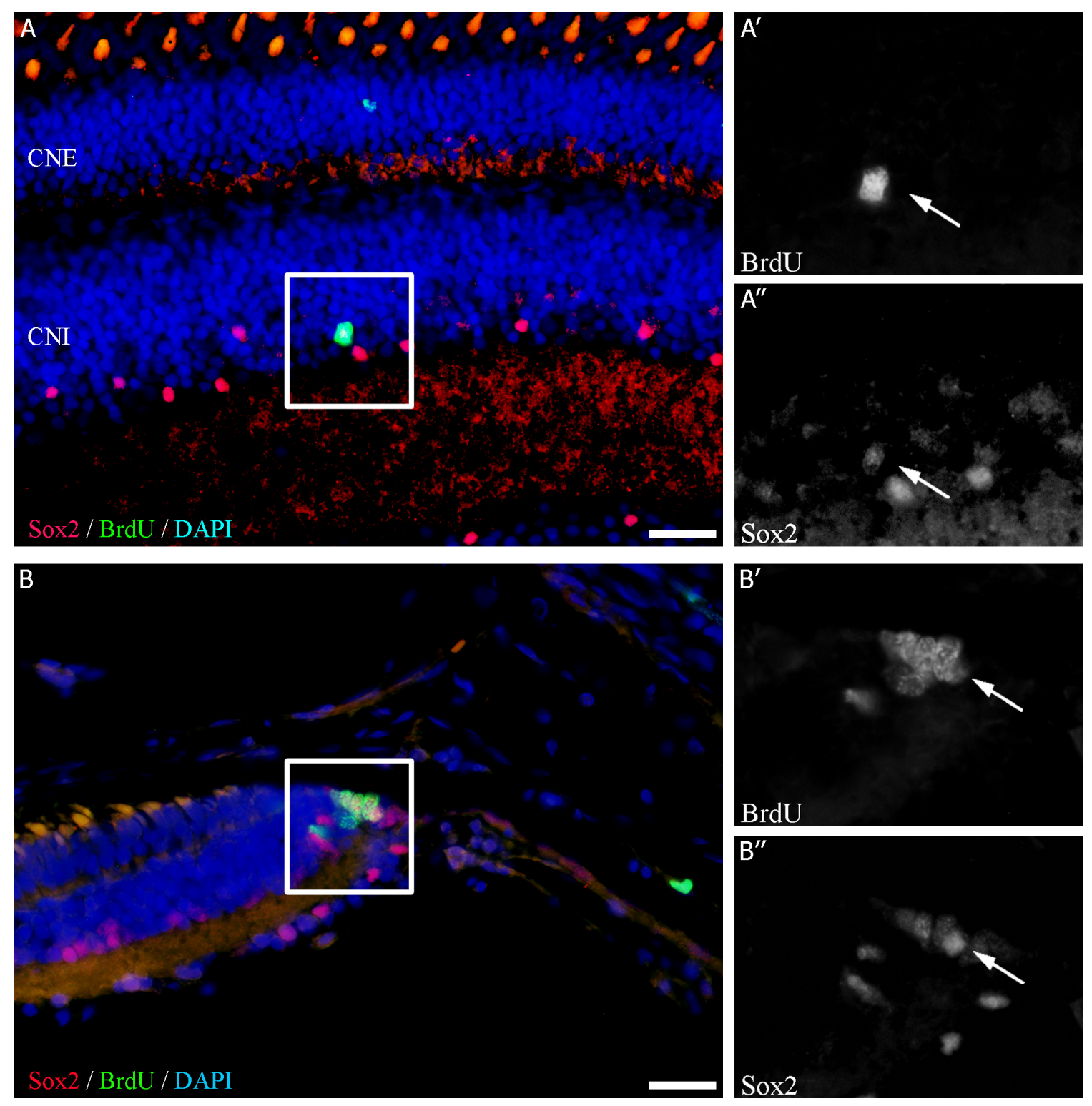

Figura 4.12: Colocalización de Sox2 y BrdU en la retina central (A) y en la ZPG (B). Hay colocalización de Sox2 y BrdU en la zona vitreal de la CNI (A, A' y A”), aunque nunca en la capa de células más próxima a la CPI. En la ZPG hay varias células donde se observa colocalización (B, B' y B"). En todos los casos a la derecha marcadas con una flecha se muestran en detalle las células que expresan Sox2 y BrdU separando los dos canales y en escala de grises. Barra de escala: $20 \mu \mathrm{m}$. 
4.3. Detección de ARNm mediante la técnica de hibridación in situ

\subsection{Detección de ARNm mediante la técnica de hibridación in situ}

Para caracterizar las celulas progenitoras de la retina neural y ampliar el estudio realizado mediante la técnica inmunohistoquímica, hemos estudiado la localización del ARN mensajero de distintos genes (Islet, Shh, nestina) y su colocalización con BrdU. Se ha combinado la técnica de hibridación in situ para las distintas sondas revelada con NBT/BCIP (color azul), y la técnica inmunohistoquímica contra BrdU revelada con el método ABC (color marrón).

\subsubsection{Islet1}

\section{Expresión de Islet1 en la retina adulta del pez cebra}

Islet1 se expresa en la retina adulta del pez cebra, tanto en la retina central (Fig. 4.13 A y B) como en la ZPG (Fig. 4.13 C y D).

En la retina central hay células marcadas en la CNI y en la CCG. Las células son redondeadas, de tamaño mediano y se distribuyen homogéneamente por toda la CNI (Fig. 4.13 B). La intensidad del marcaje de estas células es variable, encontrándose células fuertemente marcadas, junto a otras marcadas débilmente. En la CCG las celulas marcadas son de mayor tamaño que las de la CNI, y el marcaje es intenso.

En la ZPG las células marcadas son de diverso tamaño y de distinta forma, observándose células alargadas y otras más redondeadas (Fig. 4.13 D). En esta zona se encuentra también algo de marcaje en el inicio de la CNE en la zona de transición, que no se ve en la retina central.

\section{Colocalización de Islet1 y BrdU}

Tanto en la ZPG como en la retina central encontramos colocalización de Islet1 y BrdU (Fig. 4.14). En la retina central la colocalización es poco frecuente y se da en la capa más vitreal de la CNI (Fig. 4.14 A y B). Las células doblemente marcadas 

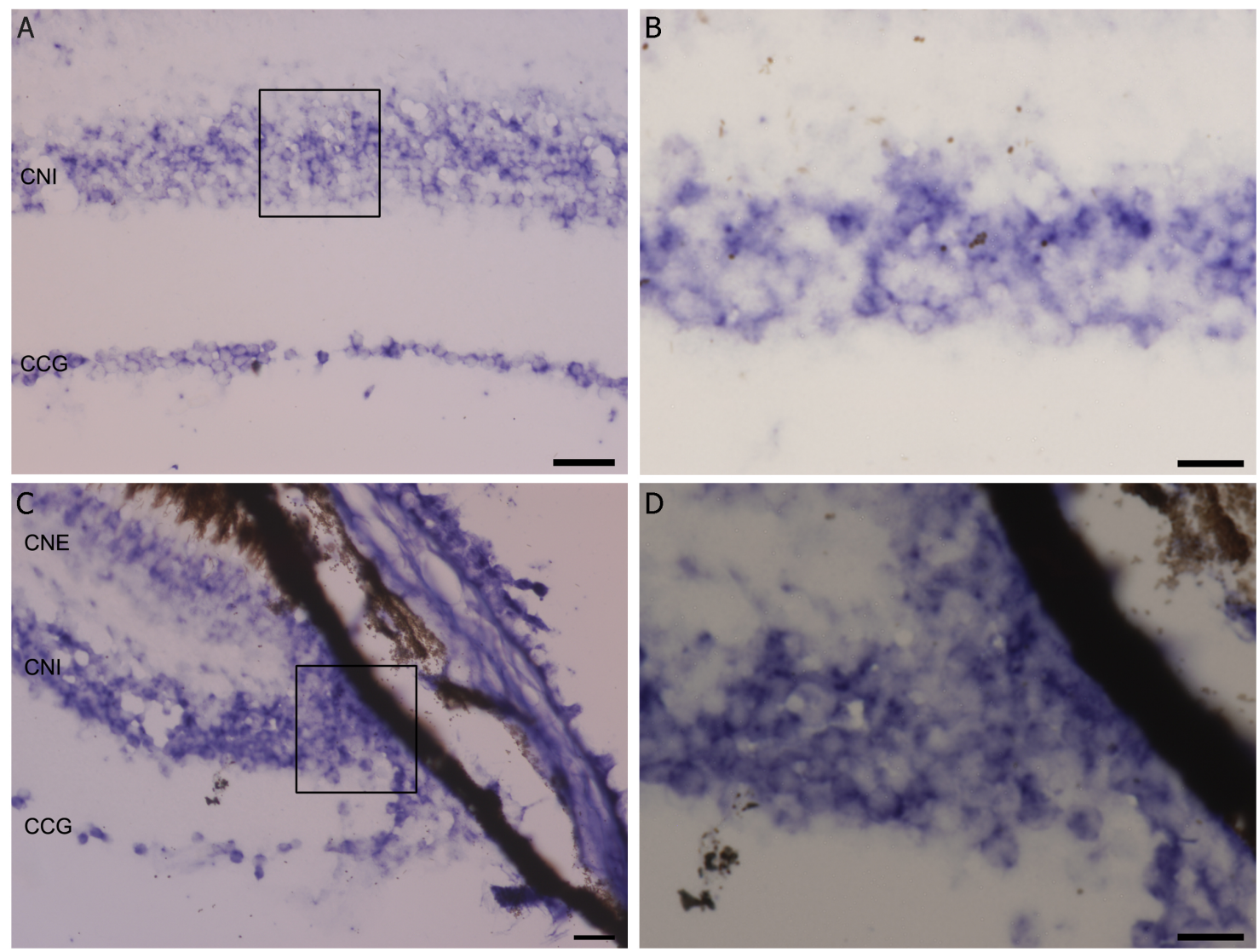

Figura 4.13: Detección del ARNm de Islet1 mediante la técnica de hibridación in situ. En la retina central hay expresión de Islet1 en la CNI y la CCG (A y B). En la ZPG se detecta el ARNm de Islet1 en células de distinto tamaño (C y D). Las imágenes B y D son una ampliación de las zonas marcadas en A y C, respectivamente. Barras de escala: A y C $20 \mu \mathrm{m}$; B y D $10 \mu \mathrm{m}$. 
4.3. Detección de ARNm mediante la técnica de hibridación in situ
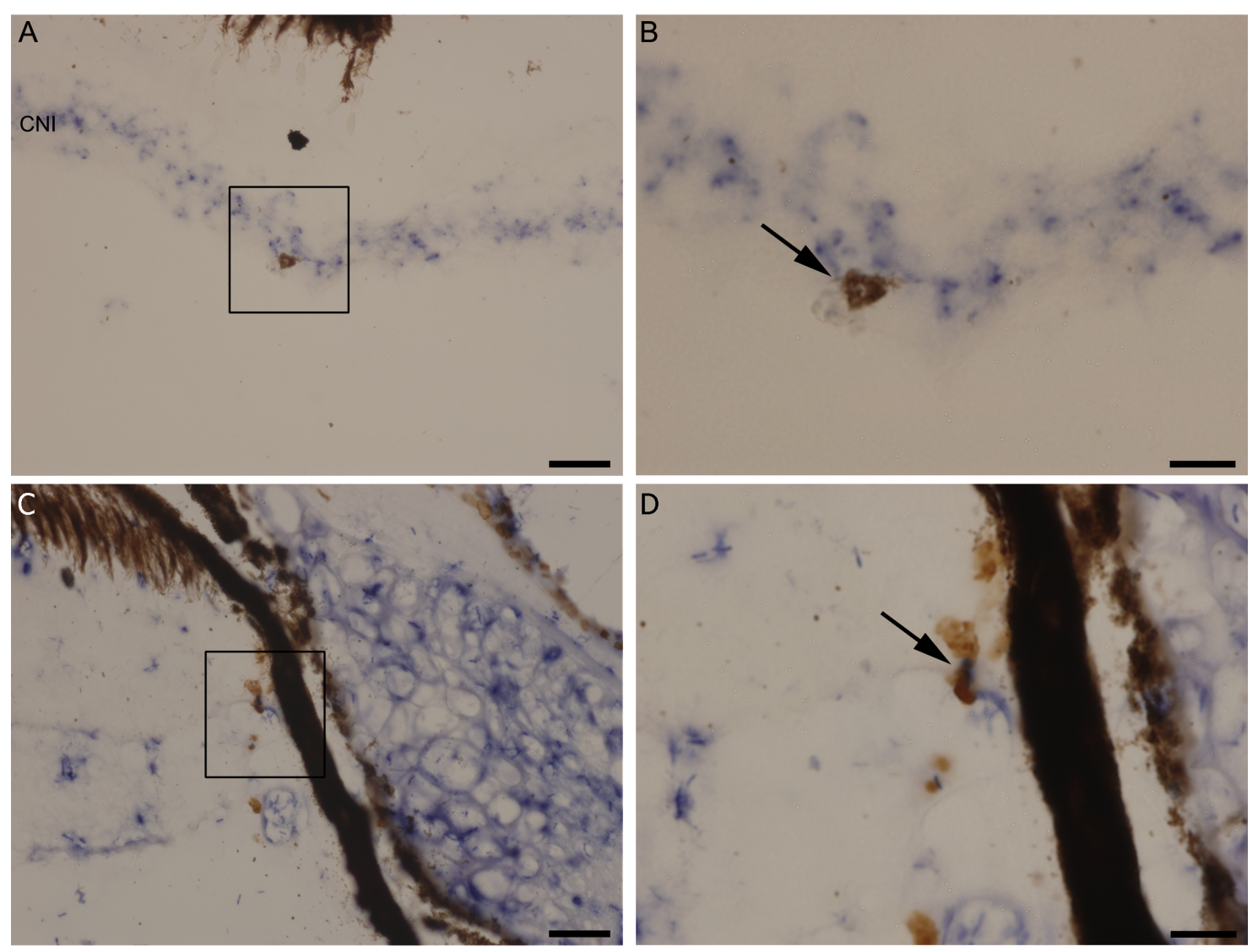

Figura 4.14: Colocalización del ARNm de Islet1 y BrdU, en la CNI de la retina central (A y ampliación en B) y en la ZPG (C y ampliación en D). En B y D aparecen marcadas con una flecha las células donde hay colocalización. Las imágenes B y D son una ampliación de las zonas marcadas en A y C, respectivamente. Barras de escala: A y C $20 \mu \mathrm{m}$; B y D $10 \mu \mathrm{m}$.

son redondeadas. En la ZPG hay colocalización de Islet1 y BrdU en la zona de transición hacia la retina central (Fig. 4.14 C y D). No se aprecia colocalización de estos marcadores en la zona más externa de la ZPG.

\subsubsection{Shh}

\section{Expresión de Shh en la retina adulta del pez cebra}

Tras realizar la técnica de hibridación in situ con la sonda de sonic hedgehog (Shh) observamos marcaje principalmente en la CNI y en la CCG (Fig. 4.15 A y B). Hay un marcaje más débil en la capa de los fotorreceptores, pero no es específico, 

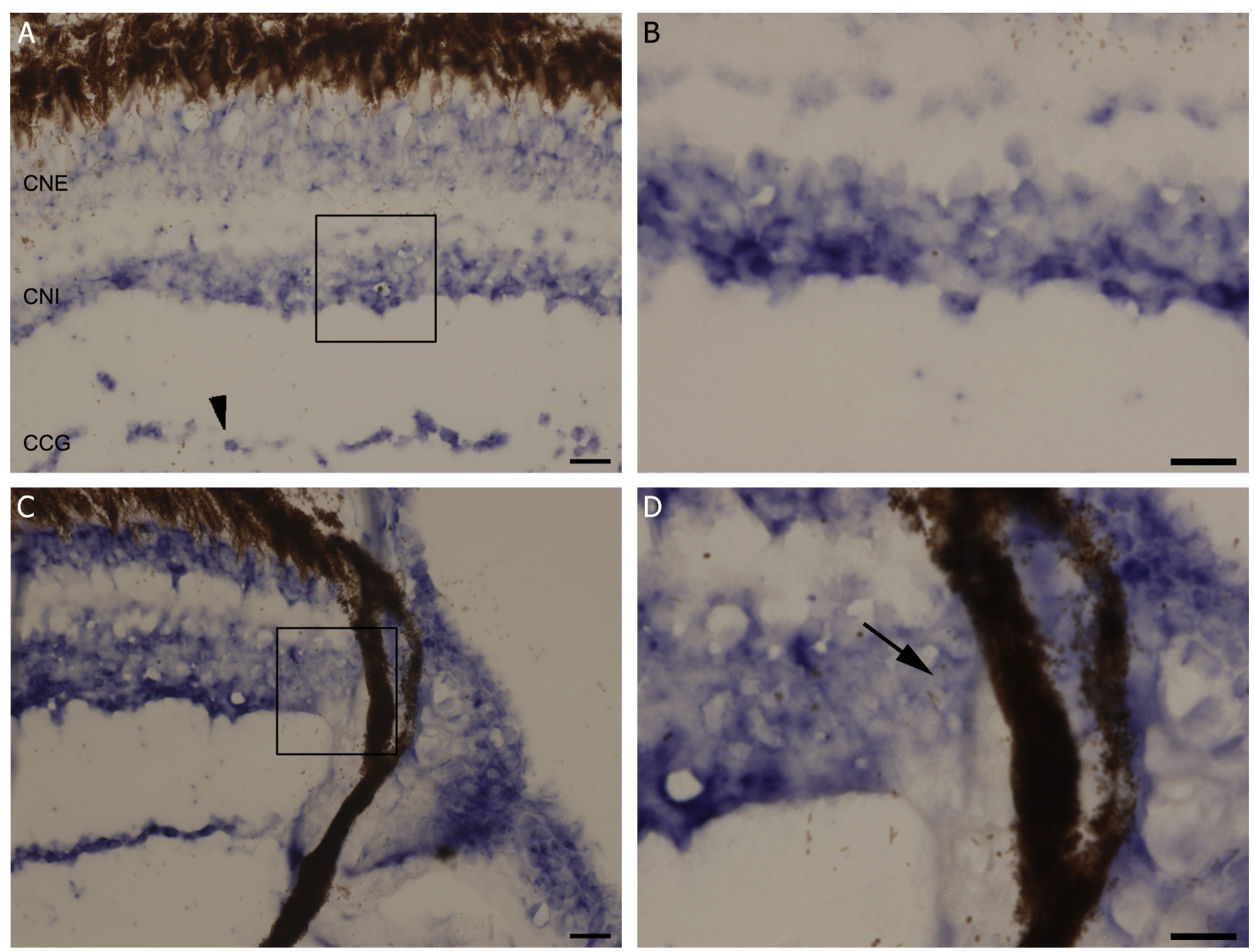

Figura 4.15: Hibridación in situ con la sonda para Shh en la retina central (A y ampliación en B) y en la ZPG (C y ampliación en D). En la retina central Shh se expresa en la CCG (punta de flecha en A) y en todo el grosor de la CNI (B). No se detecta el ARNm de Shh en la ZPG, aunque sí en la zona de transición (flecha en D). Las imágenes $\mathrm{B}$ y D son una ampliación de las zonas marcadas en A y C, respectivamente. Barras de escala: A y C $20 \mu \mathrm{m}$; B y D $10 \mu \mathrm{m}$.

ya que aparece también en los controles negativos. En la CNI las células marcadas tienen un núcleo redondeado (Fig. 4.15 A y B) y hay células con distinta intensidad de marcaje. Por lo general, las células más intensamente marcadas se localizan en la zona más vitreal (Fig. 4.15 A y B).

No se observa marcaje de Shh en la ZPG (Fig. 4.15 C y D), aunque sí en la zona de transición. 

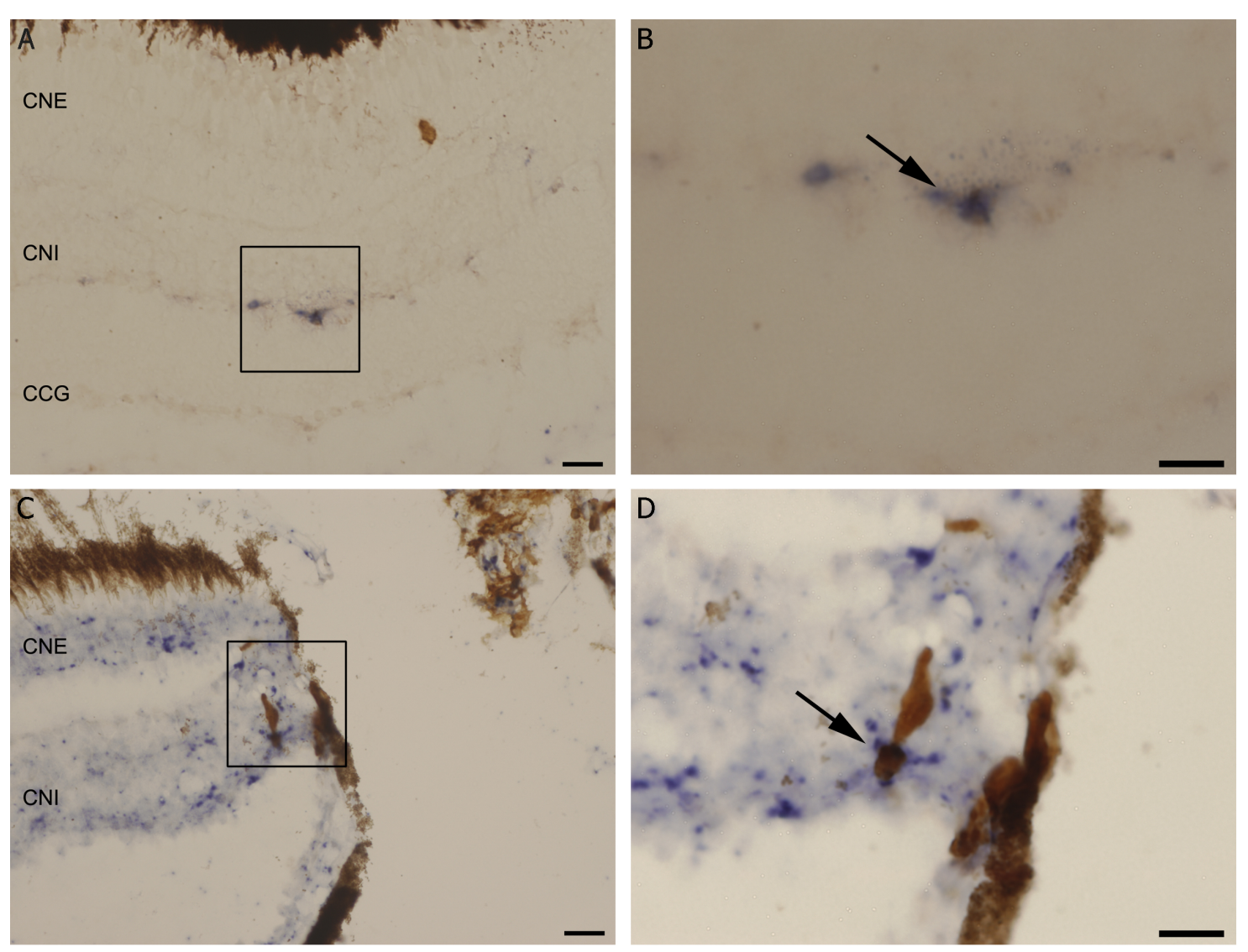

Figura 4.16: Colocalización del ARNm de Shh y BrdU combinando las técnicas de hibridación in situ e inmunohistoquímica. Hay colocalización en la CNI de la retina central (A y flecha en B), y en la zona de transición (C y flecha en D). El marcaje de la hibridación es menor tras la aplicación de $\mathrm{HCl}$, necesario para la inmunohistoquímica contra BrdU. Las imágenes B y D son una ampliación de las zonas marcadas en A y C, respectivamente. Barras de escala: A, C y E $20 \mu \mathrm{m}$; B, D y F $10 \mu \mathrm{m}$.

\section{Colocalización de Shh y BrdU}

Combinando las técnicas de hibridación in situ e inmunohistoquímica, estudiamos la colocalización de Shh y BrdU en la retina central y en la ZPG (Fig. 4.16). Aunque parte del marcaje de la hibridación se pierde al incubar las secciones con BrdU, observamos colocalización en la capa más vitreal de la CNI (Fig. 4.16 A y B). Hay también células que expresan ambos marcadores en la zona de transición junto a la ZPG (Fig. 4.16 C y D). 
Figura 4.17: Electroforesis de la digestión de dos plásmidos que contienen distintos insertos. Cada uno de los plásmidos ha sido digerido con EcoRI para demostrar que se había insertado correctamente la sonda, y con XhoI para estudiar la orientación. La sonda 1 (flecha blanca) produce una banda de 372 pares de bases (pb) y la sonda 2 (flecha amarilla) una de 412 pb.

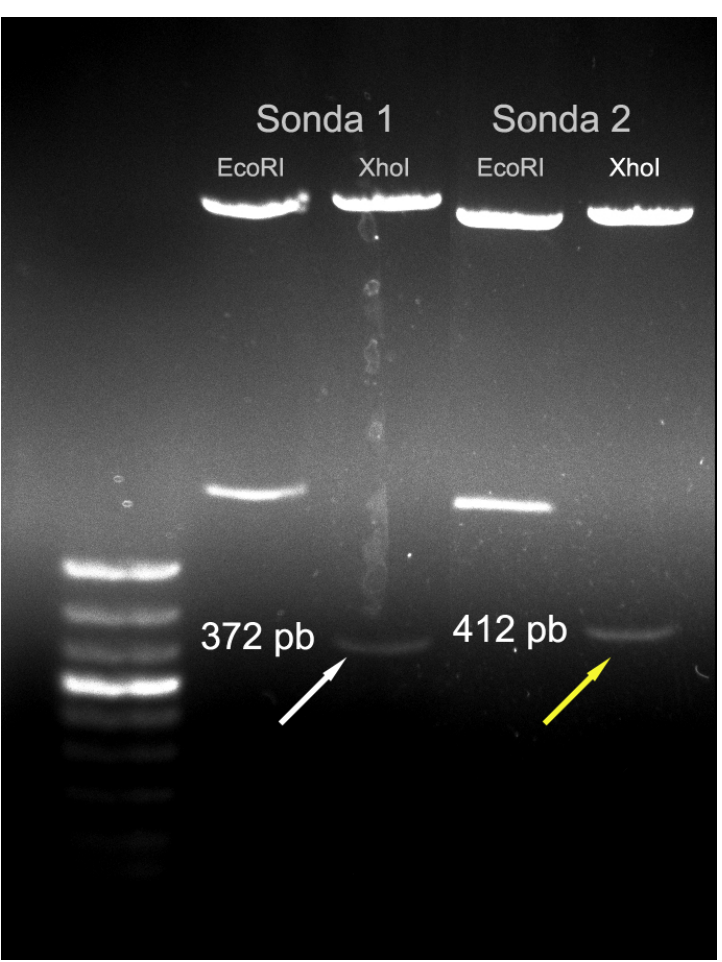

\subsubsection{Nestina}

\section{Diseño y generación de la sonda de Nestina}

Dado el interés que genera la nestina para estudiar los progenitores neurales y ante la ausencia de un anticuerpo de marcaje específico y fiable y de una sonda apropiada, procedimos al diseño y generación de una sonda específica contra el ARNm de la nestina. Para ello, tal como se ha señalado en el apartado de material y métodos, a partir del ARN obtenido de embriones de 48 horas se diseñó una sonda de nestina. Tras insertarlo en un plásmido adecuado se comprobó tanto la inserción como la orientación por medio de la digestión con distintas enzimas de restricción. La orientación es fundamental dado que se necesita una sonda sentido, complementaria del ARNm de nestina, y una sonda antisentido, copia del ARNm, que utilizamos como control negativo. Así, obtuvimos dos sondas, una con orientación 3' $\rightarrow$ 5' de 372 pares de bases que utilizamos como sonda sentido (Fig. 4.17, Sonda 1) y la sonda antisentido con orientación 5' $\rightarrow$ 3', de 412 pares de bases (Fig. 4.17, Sonda 2). 


\section{Expresión de Nestina en la retina adulta del pez cebra}

Con las sondas sintetizadas, se realizó la técnica de hibridación in situ, tanto con la sonda sentido (Fig. 4.18 A, C y E), como con la sonda antisentido (Fig. 4.18, B, D y F) como control negativo.

La nestina se expresa tanto en la retina central (Fig. 4.19, A- D) como en la ZPG (Fig. 4.19, E y ampliación en F). En la retina central se ve marcaje practicamente en toda la CNI y en la CCG (Fig. 4.19 A, C). Se observa en células redondeadas, sin diferencias apreciables en la intensidad de marcaje entre ellas. Hemos observado marcaje en los fotorreceptores, pero consideramos que es debido al tiempo excesivo de revelado, ya que con un tiempo menor permanece el marcaje en las células de la CNI pero no en los fotorreceptores (Fig. 4.19 C y D).

En la ZPG las células marcadas son principalmente alargadas y están intensamente marcadas (Fig. 4.19, E y F).

Cuando realizamos la técnica de hibridación in situ con la sonda antisentido no se observa ningún tipo de marcaje (Fig. 4.18, B, D y F).

\section{Colocalización de Nestina y BrdU}

Tras realizar la técnica de hibridación in situ seguida de la técnica inmunohistoquímica contra BrdU, se ha estudiado donde hay células que expresan ambos marcadores (Fig. 4.20). En la retina central se ha encontrado colocalización de ambos marcadores en la capa más vitreal de la CNI (Fig. 4.20 A y B) y en la CCG (Fig. 4.20 C y D). Son células de morfología redondeada en ambos casos, aunque los núcleos de las células de la CCG son más grandes. Hay también colocalización de nestina y BrdU en la ZPG (Fig. 4.20 E y F), en células alargadas y de pequeño tamaño. 


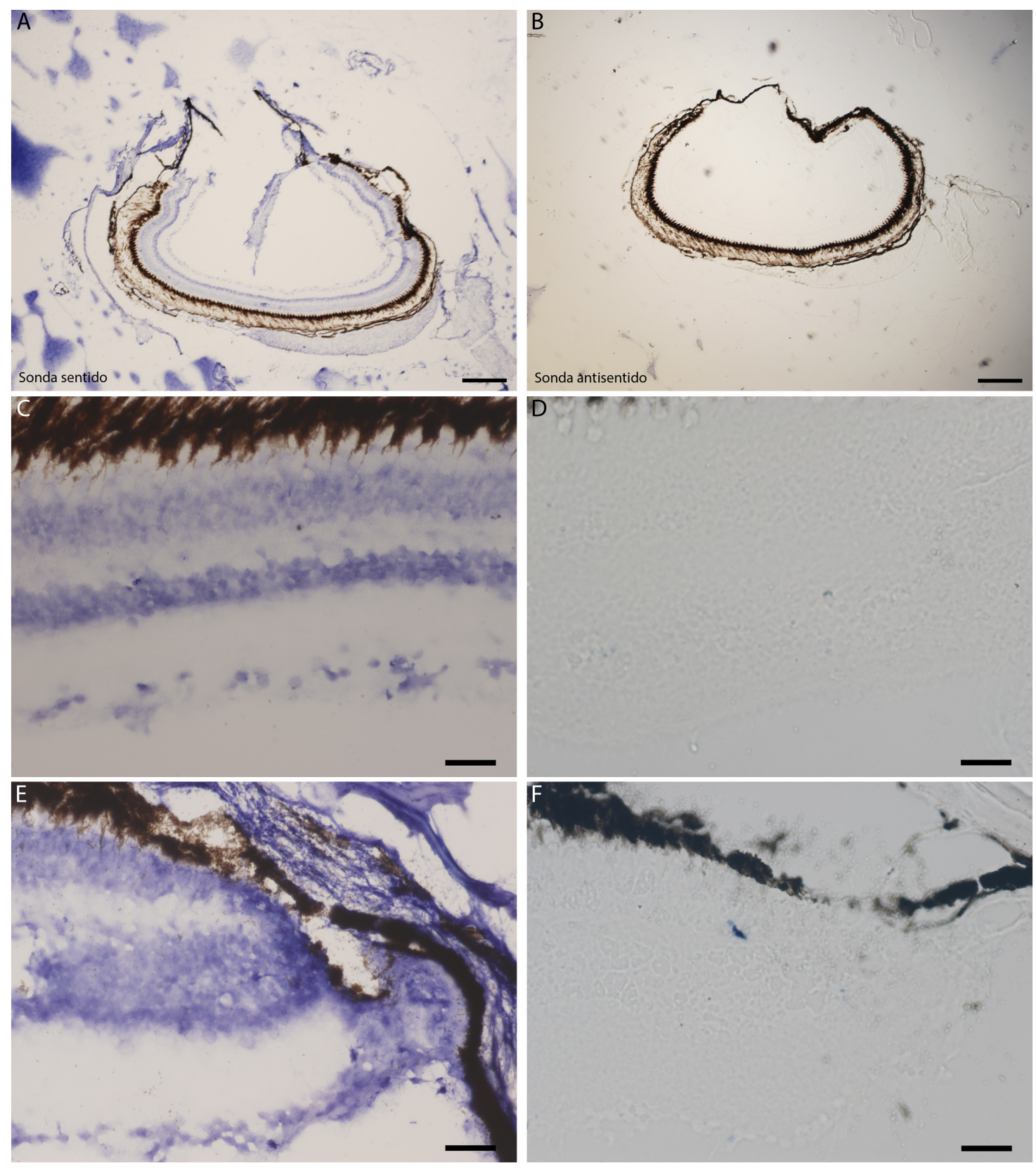

Figura 4.18: Hibridación in situ con la sonda para detectar el ARNm de nestina. Se muestran resultados de la sonda sentido (A, C y E) y la sonda antisentido (B, D y F). Para cada una se ha seleccionado una imagen general (A y B), y una imagen en detalle de la retina central (C y D) y de la ZPG (E y F). Barras de escala: A y B $200 \mu \mathrm{m}$; C-F $50 \mu \mathrm{m}$. 

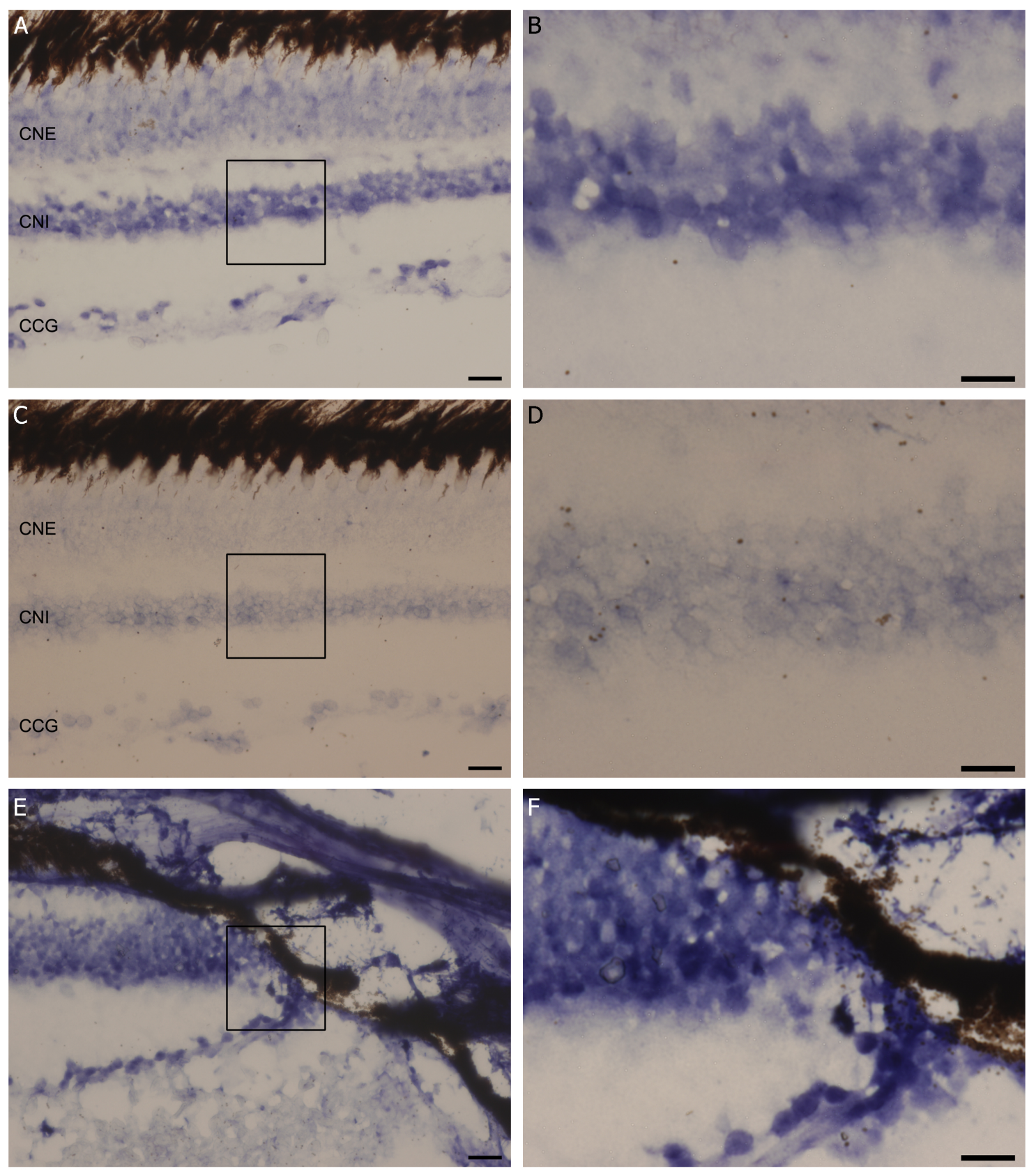

Figura 4.19: Imágenes de la técnica de hibridación in situ para la sonda de nestina. Hay marcaje tanto en la retina central (A-D) como en la ZPG (E y ampliación en F). Variando el tiempo de revelado, se observa un cambio en la intensidad general de marcaje, siendo este fuerte tras 2 horas de revelado (A y ampliacion en B), y débil si el revelado es de media hora ( $\mathrm{C}$ y ampliacion en $\mathrm{D}$ ). Barra de escala: A, C y E $20 \mu \mathrm{m}$; B, D y F $10 \mu \mathrm{m}$. 

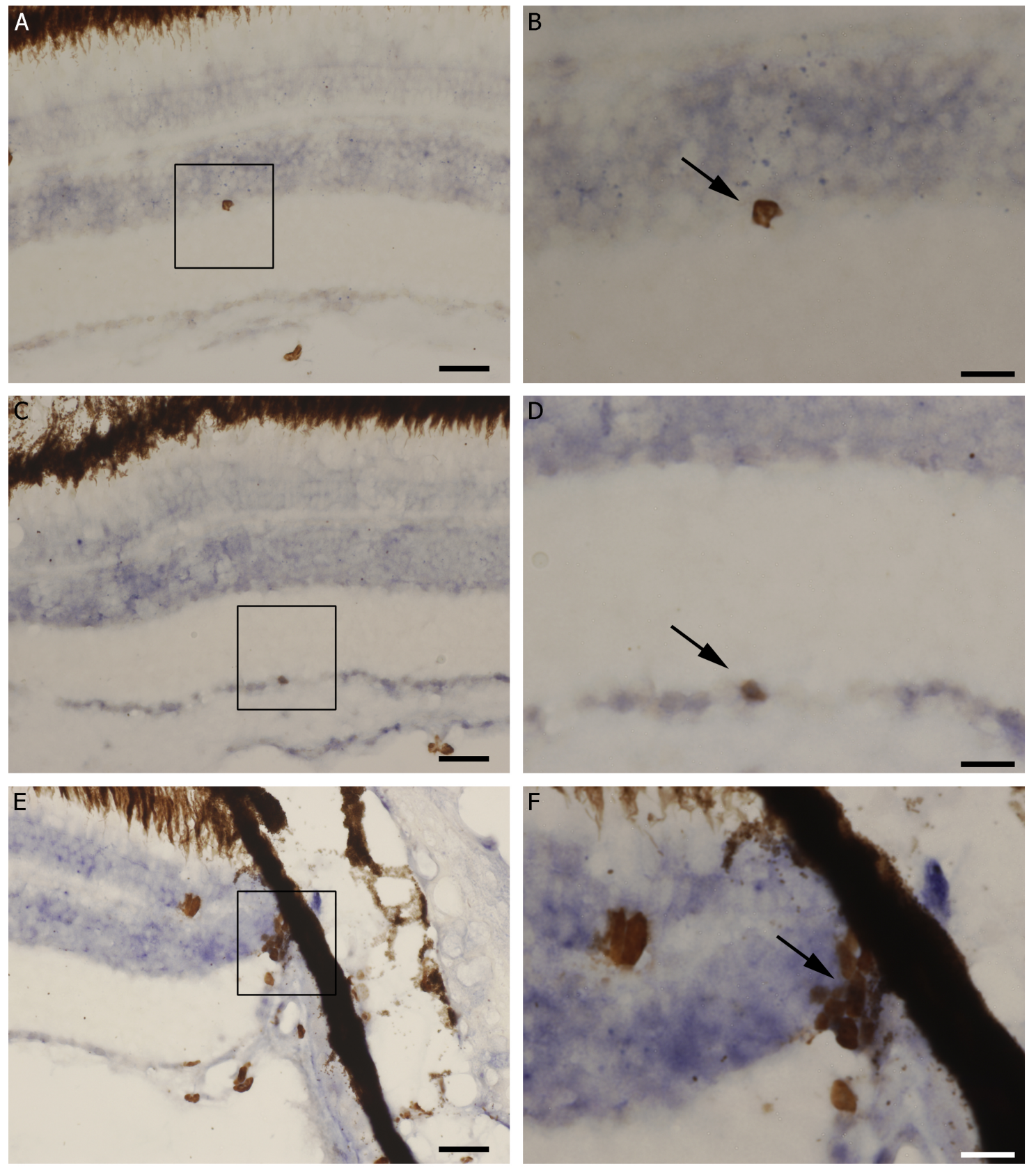

Figura 4.20: Colocalización del ARNm de Nestina y BrdU en la CNI (A y ampliación en B), en la CCG (C y ampliación en D) y en la ZPG (E y ampliación en F). Las células que colocalizan están marcadas con una flecha en B, D y F. Barras de escala: A, C y E $20 \mu \mathrm{m}$; B, D y F $10 \mu \mathrm{m}$. 
4.4. Estudio in vitro de las células progenitoras

\subsection{Estudio in vitro de las células progenitoras}

\subsubsection{Adaptación del protocolo de cultivo de las células pro- genitoras de retina de pez cebra}

El cultivo de células progenitoras de la retina de peces cebra se realizó basándonos en el protocolo puesto a punto en nuestro laboratorio para células de la retina del carpín (Sánchez-González, 2009). Al tratarse de dos especies cuyo hábitat es diferente, en particular las condiciones térmicas, ha sido necesario adaptar el protocolo al pez cebra. Dicho protocolo consiste, en resumen, en la extracción de las retinas, su disgregación mecánica y enzimática mediante una mezcla de papaína, DNAsa y dispasa y el posterior cultivo a $20^{\circ} \mathrm{C}$ en un medio Neurobasal A suplementado (Cuadro 4.1). Cada dos días se centrifugan las células y se cambia de medio. Mientras que la temperatura funcional del carpín es de $20^{\circ} \mathrm{C}$, la del pez cebra es de $28,5^{\circ} \mathrm{C}$. Por ello hemos cambiado la temperatura del cultivo a $28,5^{\circ} \mathrm{C}$, tras comprobar que el medio se mantenía estable. Las condiciones de $\mathrm{CO}_{2}$, pH y disgregación se han mantenido similares a las del cultivo de células del carpín. Hemos ensayado variaciones en la concentración de los componentes del medio de cultivo para adecuar éste a la nueva temperatura (Cuadro 4.1). Además se ha modificado el procedimiento de cambio de cultivo, ya que se han añadido factores de crecimiento cada dos días, y a los 7 días se procede a una disgregación enzimática acompañada de un cambio de medio, conservando parte del medio anterior (Haslinger et al., 2009).

\begin{tabular}{|c|c|c|c|}
\hline \multicolumn{4}{|c|}{ Medio Neurobasal A suplementado } \\
\hline \multicolumn{2}{|c|}{ Componentes } & Sánchez-González, 2009 & Adaptación \\
\hline \multirow{2}{*}{ Factores de crecimiento } & EGF & $20 \mathrm{ng} / \mathrm{mL}$ & $20 \mathrm{ng} / \mathrm{mL}$ \\
& bEGF & $20 \mathrm{ng} / \mathrm{mL}$ & $20 \mathrm{ng} / \mathrm{mL}$ \\
\hline \multirow{3}{*}{ Antibióticos } & Estreptomicina & $100 \mathrm{U} / \mathrm{mL}$ & $100 \mathrm{U} / \mathrm{mL}$ \\
& Penicilina & $100 \mathrm{U} / \mathrm{mL}$ & $100 \mathrm{U} / \mathrm{mL}$ \\
& Ciprofloxacino & $4 \mu \mathrm{g} / \mathrm{mL}$ & $1 \mu \mathrm{g} / \mathrm{mL}$ \\
\hline Antifúngico & Anfotericina B & $100 \mu \mathrm{g} / \mathrm{mL}$ & $100 \mu \mathrm{g} / \mathrm{mL}$ \\
\hline Suplemento comercial & B27 & $20 \mu \mathrm{L} / \mathrm{mL}$ & $20 \mu \mathrm{L} / \mathrm{mL}$ \\
\hline \multicolumn{2}{|c|}{ L-Glutamina } & $200 \mathrm{mM}$ & $200 \mathrm{mM}$ \\
\hline \multicolumn{2}{|c|}{ Heparina } & $2 \mu \mathrm{g} / \mathrm{mL}$ & $2 \mu \mathrm{g} / \mathrm{mL}$ \\
\hline
\end{tabular}

Cuadro 4.1: Comparación de los medios utilizados en Sánchez-González (2009) y el utilizado en este trabajo 


\section{Glutamina/Glutamax}

En estudios anteriores se ha descrito que la glutamina libera amonio en diluciones acuosas, pudiendo este subproducto ser tóxico para las células (Tritsh y Moore, 1962; Schneider et al., 1996). Se ha postulado que utilizando un dipéptido se reduce la liberación de amonio, mejorando la calidad del cultivo. Debido a esto, hemos probado a utilizar un producto denominado Glutamax, que está compuesto por el dipéptido L-alanina-L-glutamina, a la misma concentración que se utiliza la L-Glutamina (200 mM). Para evitar que los resultados dependieran de otros parámetros, se cultivó simultáneamente uno de los pocillos con L-Glutamina, y el otro con Glutamax. El experimento se repitió cuatro veces. No se observaron diferencias colorimétricas entre ambos pocillos. Ello significa que no hay variación en el pH, por lo que suponemos que tampoco hay liberación de amonio. Por todo ello, decidimos utilizar L-Glutamina.

\section{Concentración de antibióticos}

La temperatura a la que los antibióticos convencionales funcionan con más efectividad es a la temperatura corporal humana. En el protocolo del que partíamos la concentración de antibióticos utilizada era de $4 \mu \mathrm{g} / \mathrm{mL}$ de ciprofloxacino y de 100 $\mathrm{U} / \mathrm{mL}$ de penicilina y estreptomicina. Hemos ensayado distintas concentraciones de antibióticos, tanto del ciprofloxacino como de la penicilina y la estreptomicina. Las concentraciones ensayadas para el ciprofloxacino fueron de 4, 2, 1 y $0,5 \mu \mathrm{g} / \mathrm{mL}$. Las concentraciones probadas para la penicilina y la estreptomicina fueron de $100 \mathrm{U} / \mathrm{mL}$ a 50,25 y $10 \mathrm{U} / \mathrm{mL}$.

Primero se probó a variar la concentración de ciprofloxacino. No observamos contaminación en ninguno de los pocillos, lo que supone que una concentración menor era suficiente para detener el crecimiento bacteriano. De hecho, a los 7 días en cultivo, la diferencia tanto en el número de neuroesferas, como en el tamaño de éstas es considerable (Fig. 4.21). Para corroborar estos datos contamos el número de neuroesferas a los 7 días en cultivo para realizar un análisis estadístico (Fig. 4.22). Consideramos neuroesferas un grupo de al menos 8 células. Los resultados indican una diferencia significativa en el número de neuroesferas en cultivo entre la concentración de $4 \mu \mathrm{g} / \mathrm{mL}$ de ciprofloxacino y el resto de las concentraciones. La mayor 

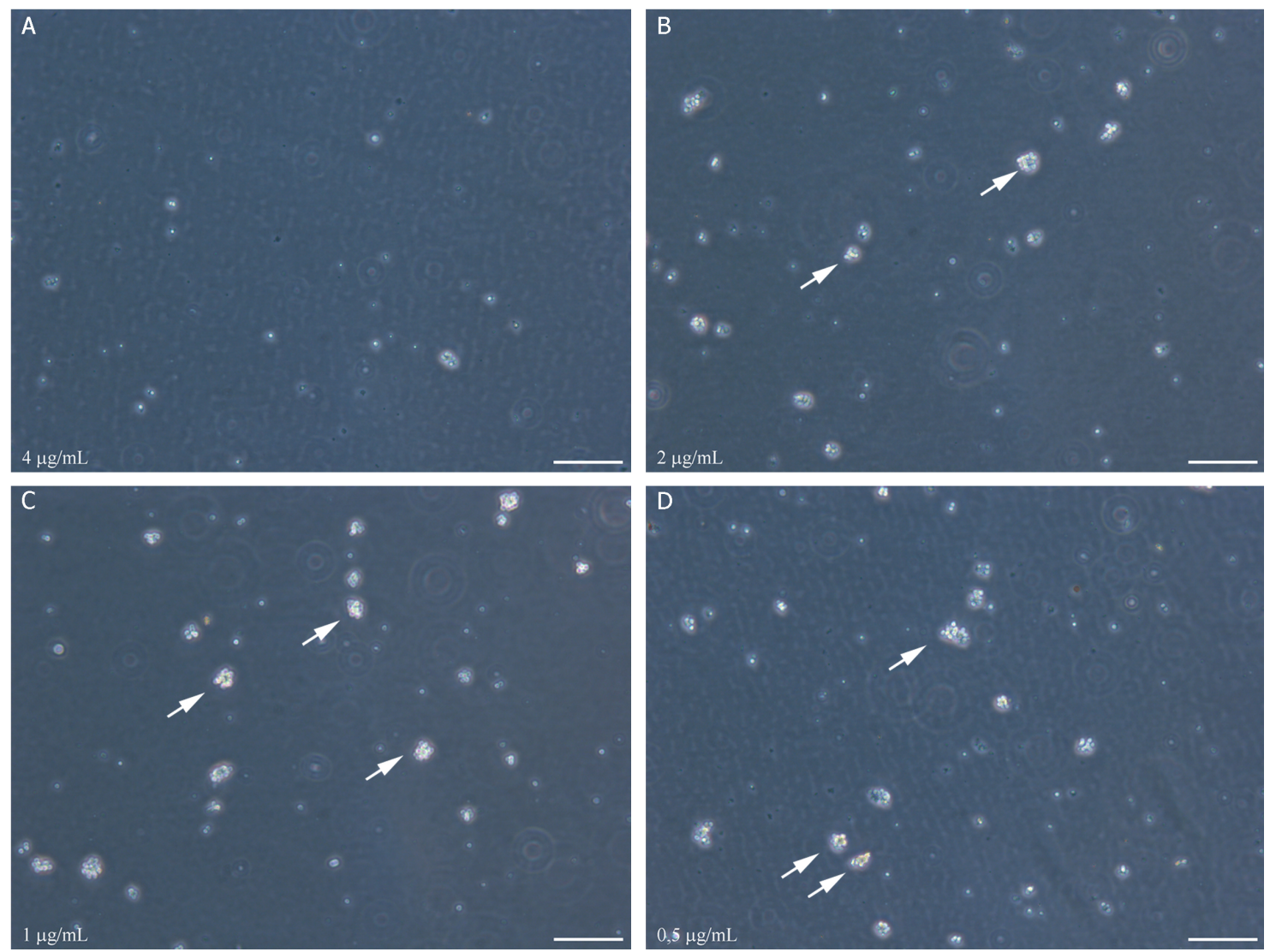

Figura 4.21: Efecto de la concentración de ciprofloxacino sobre la producción de neuroesferas en cultivo a los 7 días. Con la concentración mayor, $4 \mu \mathrm{g} / \mathrm{mL}(\mathrm{A})$, no se observan grupos de células. A medida que descendemos la concentración (B, C y D) se aprecian más grupos de células (flechas blancas). Barra de escala: $10 \mu \mathrm{m}$. 


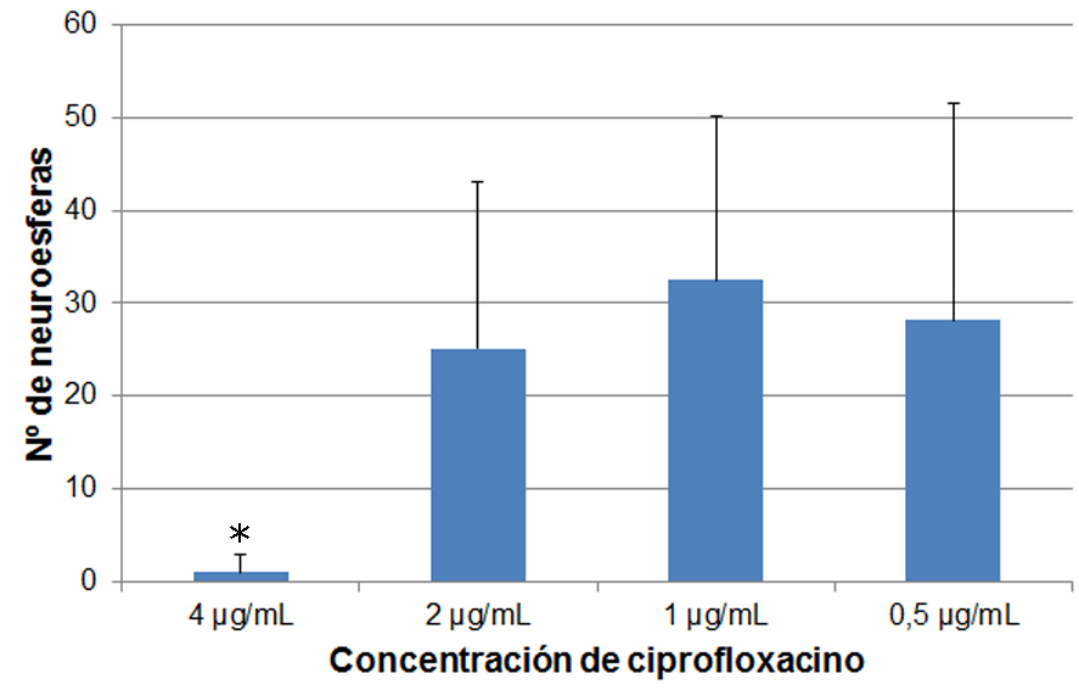

Figura 4.22: Histograma comparativo del número de neuroesferas en relación a la concentración de ciprofloxacino. El número de neuroesferas obtenidas con una concentración de $4 \mu \mathrm{g} / \mathrm{mL}$ es significativamente diferente del obtenido con las otras tres concentraciones $(\mathrm{p}<0,05)$. Entre los otros tres grupos no hay diferencias significativasBarras correspondientes a la desviación estándar.

diferencia se da entre la concentración de $4 \mu \mathrm{g} / \mathrm{mL}$ y la de $1 \mu \mathrm{g} / \mathrm{mL}(\mathrm{p}=0,005)$. Con estos resultados, decidimos elegir una concentración de $1 \mu \mathrm{g} / \mathrm{mL}$ de ciprofloxacino para realizar los siguientes cultivos.

Realizamos los mismos estudios variando la concentración de penicilina/estreptomicina. No observamos diferencias, por lo que mantuvimos la concentración inicial de $100 \mathrm{U} / \mathrm{mL}$ de penicilina/estreptomicina.

\section{Concentración inicial de células}

La concentración inicial de células es un dato determinante, ya que una concentración demasiado alta puede condicionar el acceso de las células a los factores del medio, asi como una concentración demasiado baja puede complicar la división de las células, ya que la comunicación intercelular es necesaria. Con la finalidad de determinar cual es la mejor concentración inicial de células para obtener el mayor número de neuroesferas, se ensayaron dos concentraciones: 100.000 y 200.000 células/8mL de cultivo (Fig. 4.23). Al igual que para estimar la concentración de ciprofloxacino, contamos a los 7 días el número de neuroesferas obtenido. Los resul- 


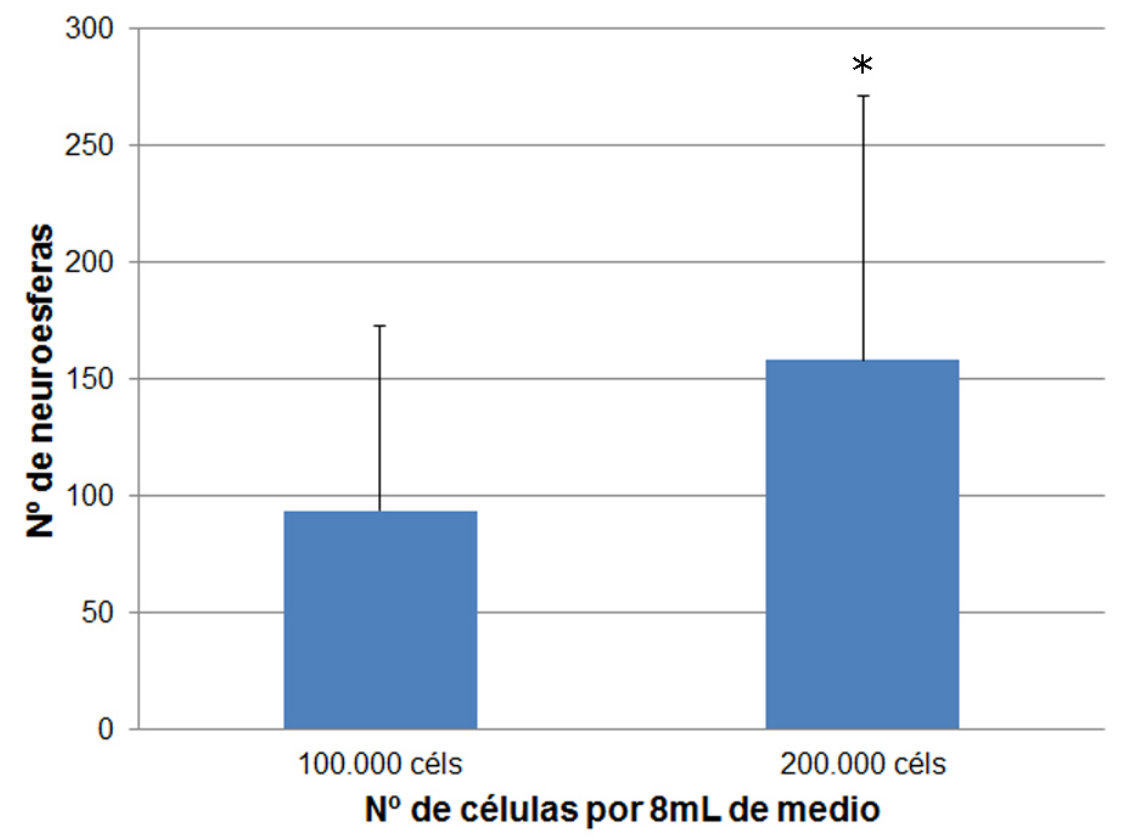

Figura 4.23: Efecto de la concentración inicial de células sobre el número de neuroesferas en cultivo a los 7 días. Utilizando 200.000 células por cada $8 \mathrm{~mL}$ de medio de cultivo se obtiene una diferencia significativa en comparación con la utilización de 100.000 células $(\mathrm{p}<0,05)$. Barras correspondientes a la desviación estándar.

tados indican que se obtiene mayor número de neuroesferas con una concentración inicial de 200.000 células por $8 \mathrm{~mL}$ de medio de cultivo.

\section{Pinzamiento del nervio óptico}

Con la idea de aumentar el número de células con capacidad de división a la hora de hacer el cultivo, probamos a realizar un pinzamiento previo del nervio óptico en los peces 8 días antes de realizar el cultivo. Antes de llevarlo a cabo en cultivos, realizamos una prueba en secciones, con tres animales control y tres pinzados a los que inyectamos BrdU 4 veces siguiendo el protocolo descrito en Material y Métodos. Los resultados indicaron que había un mayor número de células positivas a BrdU en los animales pinzados $(\mathrm{p}<0,001)$ (Fig. 4.24).

Tras comprobar en secciones el aumento del número de células en división, realizamos el cultivo. Al igual que en los ensayos anteriores comparamos el número de 


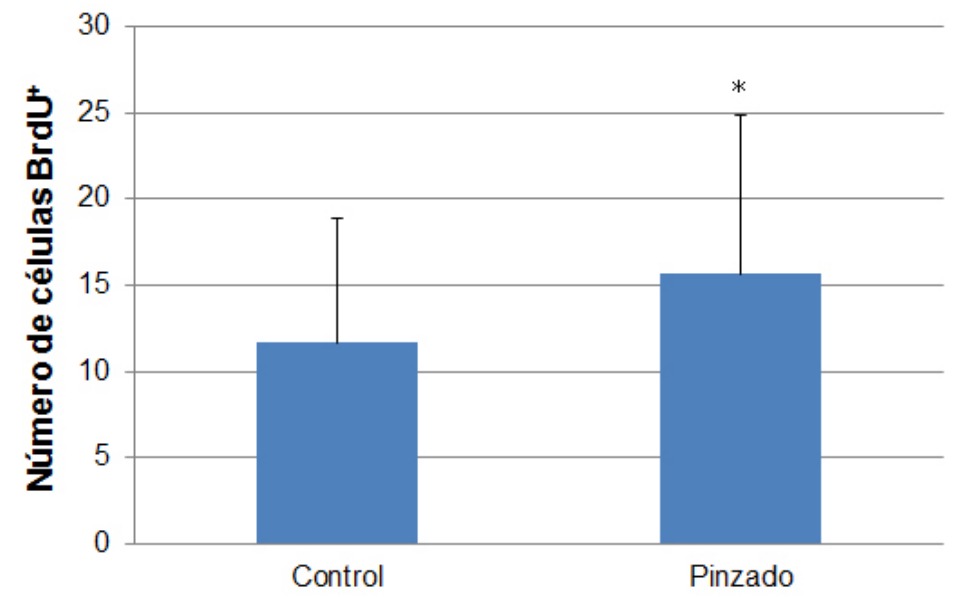

Figura 4.24: Efecto del pinzamiento del nervio óptico sobre el número de células positivas a BrdU en la retina tras 8 días post-lesión. Los animales pinzados presentan un número significativamente mayor de células marcadas $(\mathrm{p}<0,001)$. Barras correspondientes a la desviación estándar.

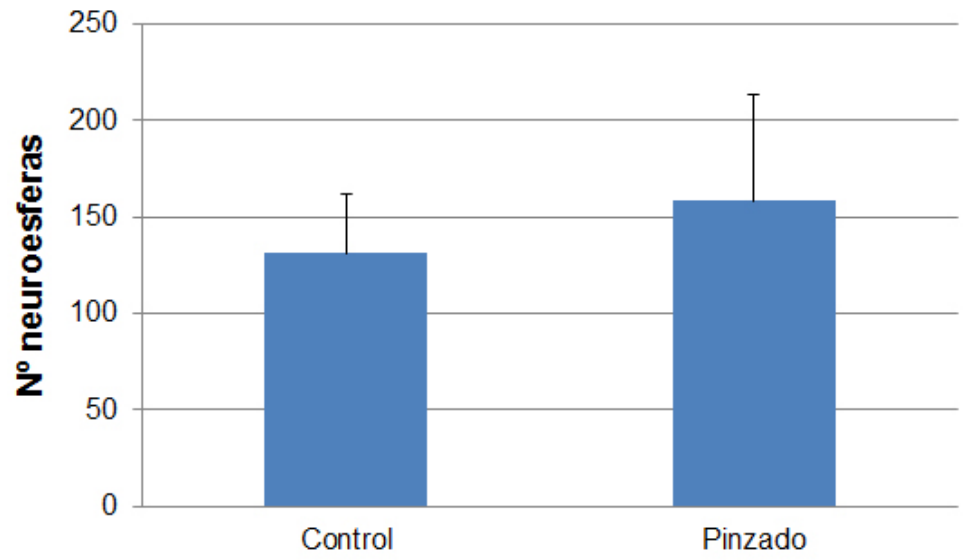

Figura 4.25: Número de neuroesferas a los 7 días en cultivo iniciado con células de peces control y de peces con el nervio pinzado 8 días antes del cultivo. No hay diferencias entre ambos grupos $(\mathrm{p}=0,505)$. Barras correspondientes a la desviación estándar.

neuroesferas que se obtenían a los 7 días en cultivo. En este caso no había diferencias entre los cultivos realizados a partir de peces control y los de los animales pinzados $(\mathrm{p}=0.50)$ (Fig. 4.25). Por ello decidimos no realizar el pinzamiento, ya que supone un daño a los animales y que no aporta ninguna ventaja al cultivo. 


\subsubsection{Evolución de las células progenitoras en cultivo}

Tras adaptar el protocolo de cultivo para el pez cebra, realizamos cultivos celulares utilizando 20 retinas para cada cultivo. Las células se sembraron bajo las condiciones óptimas, y cada dos días se les añadió factores de crecimiento. A la semana se disgregaron los cultivos con Accutase y se cambió el medio.

El primer día, después de sembrar las células, se aprecian grupos de células que no se han disgregado correctamente. Junto a ellas encontramos tanto células aisladas como grupos de dos o tres células. En este momento, además, encontramos células alargadas con prolongaciones, que por su aspecto parecen fotorreceptores (Fig. 4.26, A). Encontramos también gránulos de pigmento de color marrón procedentes de los restos de epitelio pigmentario, que siguen viéndose a lo largo de todos los periodos analizados.

Durante de la primera semana observamos células que se están muriendo de color grisáceo, y contaminación bacteriana que va desapareciendo con el tiempo. También hay pequeños grupos de dos o tres células, que a lo largo de los días van creciendo (Fig. 4.26, B).

A los siete días ya se aprecia un número muy considerable de grupos de células, de tamaño mayor (Fig. 4.26, C). En este día disgregamos el cultivo, por lo que en el día 8, sólo se observan pequeños grupos (Fig. 4.26, D). Durante la segunda semana las neuroesferas van creciendo (Fig. 4.26, E) y el día 14 ya hay en el cultivo neuroesferas de un tamaño considerable (Fig. 4.26, F).

Para analizar la evolución de los cultivos hemos medido el área de los grupos celulares a partir de micrografías de los mismos (Fig. 4.27). Se ha medido el área de los grupos celulares de al menos 4 cultivos independientes para cada uno de los días. A lo largo de los 14 días analizados, se observa un aumento en el área de los grupos celulares, excepto en el día 8, donde hay un descenso. Ello puede ser debido a que el día anterior se produce un cambio de medio acompañado de la disgregación de las esferas. La disgregación no es completa, ya que quedan algunos grupos celulares. A lo largo de la segunda semana el aumento del área de los grupos celulares es mayor. Consideramos que es debido a que en el cambio de medio se seleccionan las células progenitoras y , además, el medio de cultivo se mezcla con la mitad de medio de 


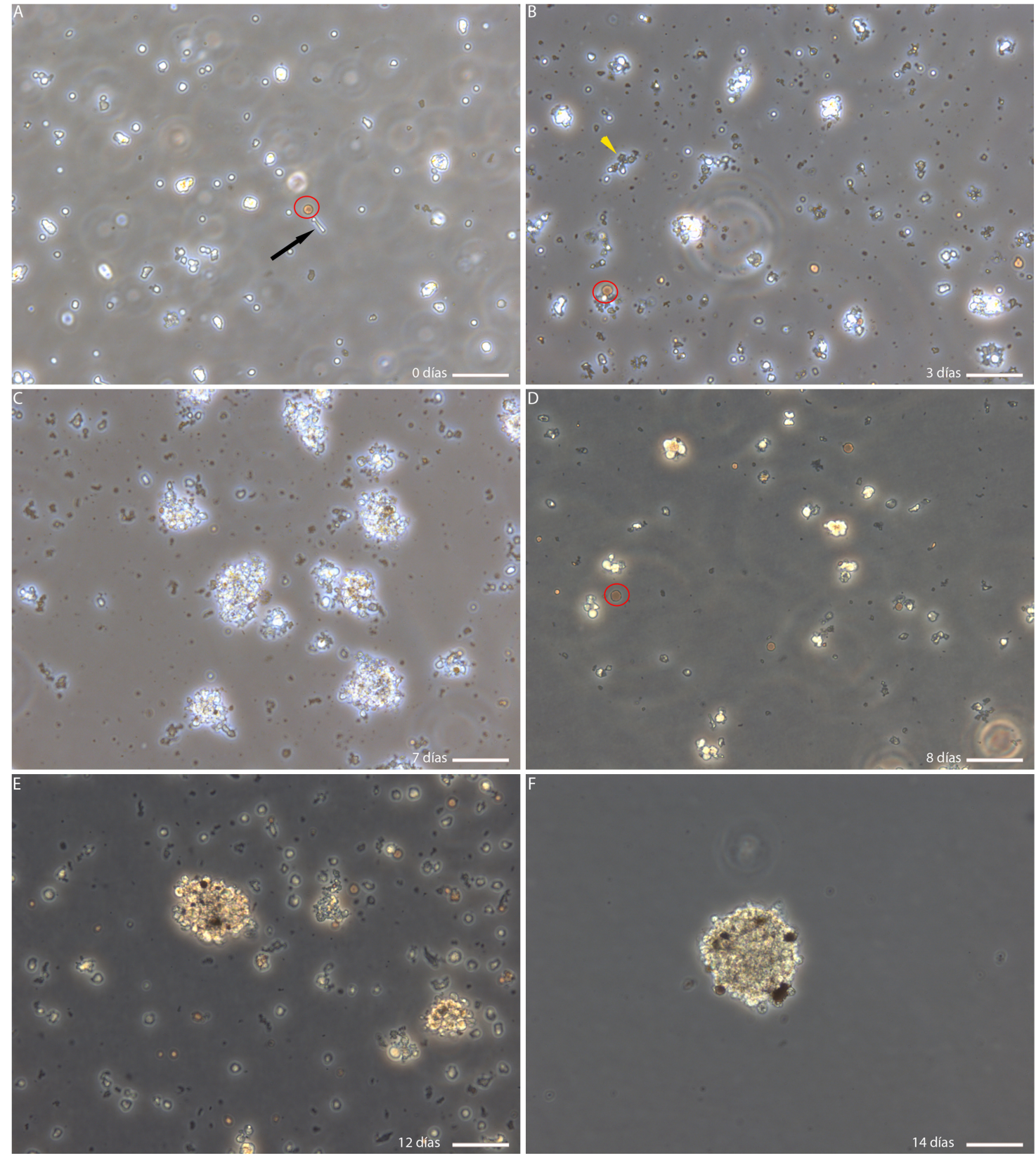

Figura 4.26: Imágenes de los cultivos de neuroesferas obtenidas a partir de células retinianas de pez cebra. A día 0 (A) se observan pequeños grupos celulares de dos o tres células, asi como posibles fotorreceptores o restos de células de Müller (flecha). Se ven también restos de epitelio pigmentario de color marrón que aparecen también en otros tiempos (círculo rojo en A, B y D). 3 días tras el cultivo (B) hay grupos de un tamaño mayor que a día 0 y restos celulares de color grisáceo (punta de flecha). Las neuroesferas se detectan en los tiempos mayores: $7(\mathrm{C}), 8(\mathrm{D}), 12(\mathrm{E})$ y $14(\mathrm{~F})$ días. Barra de escala: 50 $\mu \mathrm{m}$. 


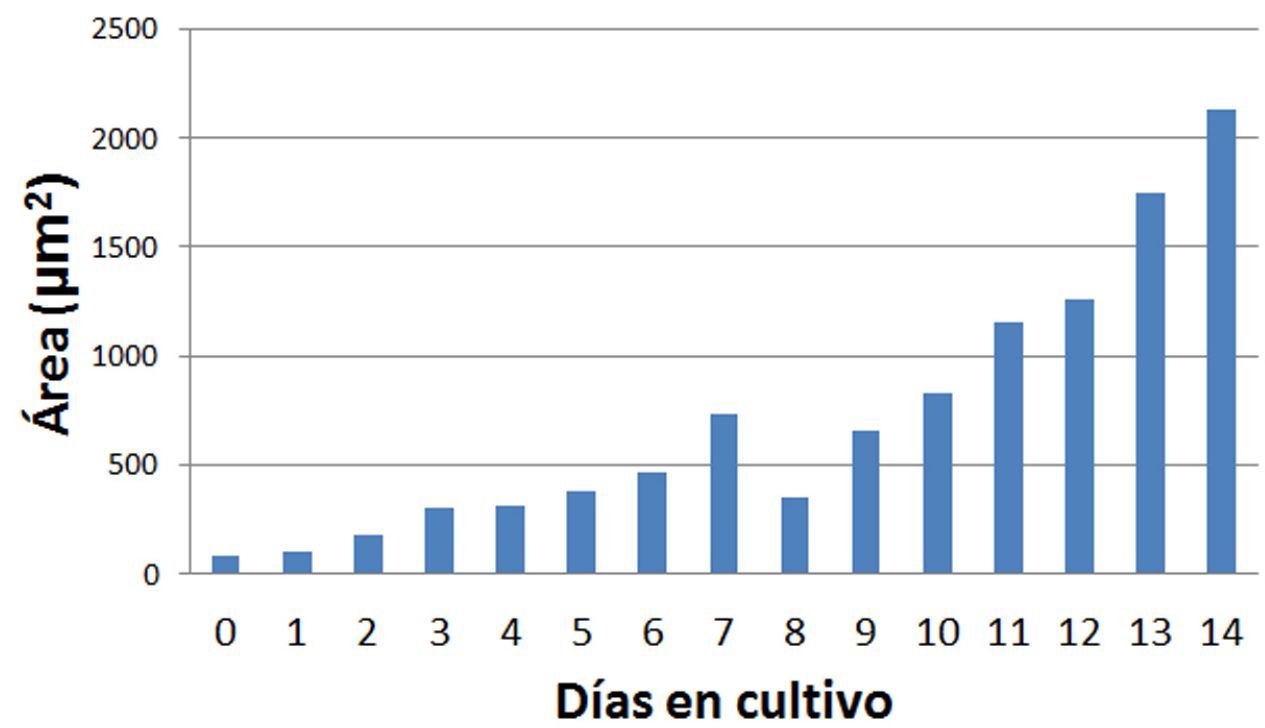

Figura 4.27: Evolución del área de las neuroesferas a lo largo de 14 días en cultivo. Las áreas varían entre las $79 \mu \mathrm{m}^{2}$ medidas el mismo día que se realiza el cultivo y las $2132 \mu m^{2}$ después de catorce días en cultivo. Se contaron grupos celulares de, al menos, cuatro cultivos independientes, considerando 48 neuroesferas para cada uno.

cultivo enriquecido donde ya han crecido previamente las esferas, lo que facilita el crecimiento.

\subsubsection{Viabilidad celular del cultivo}

Para comprobar la viabilidad y proliferación de las células en cultivo se ha realizado un ensayo MTT a tres cultivos independientes tras 1, 7 y 14 días en cultivo (Fig. 4.28). Como se puede observar en la gráfica, la viabilidad aumenta a lo largo de los días, aunque entre los 7 y 14 días el aumento es menor. Este cambio puede ser debido a que a los 7 días se realiza el cambio de medio, y las células se cultivan en el doble de volumen. 


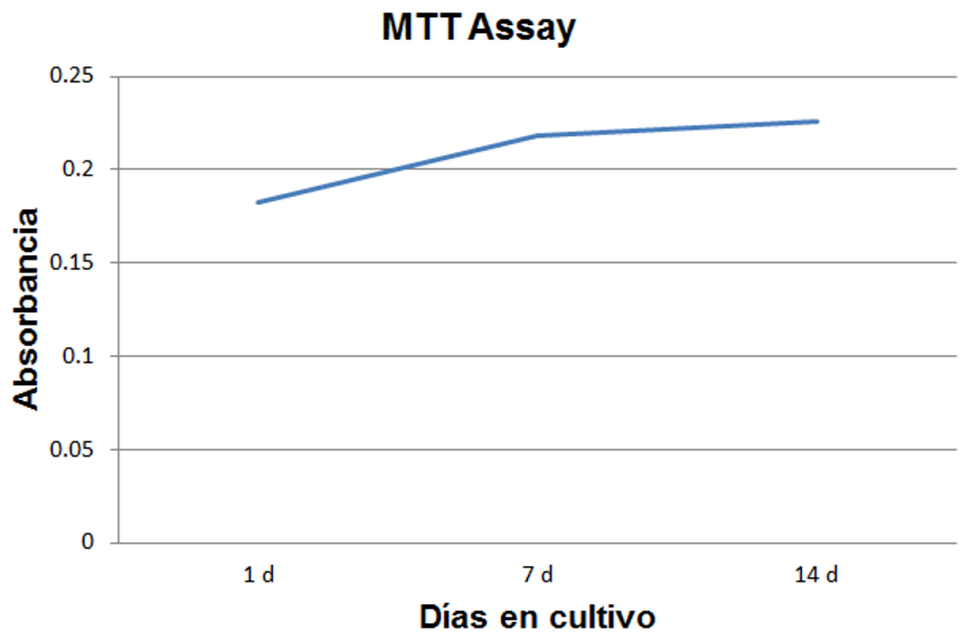

Figura 4.28: Ensayo MTT para estudiar la viabilidad de las células a los 1, 7 y 14 días en cultivo. Se han estudiado tres cultivos independientes en cada uno de los puntos.

\subsection{Inmunocitoquímica sobre neuroesferas}

Para poder realizar la técnica inmunocitoquímica sobre neurosferas, hay que adherir estas a cubreobjetos. Para ello utilizamos una dilución de Matrigel (ver 3.5). La concentración de partida de 1:100 la tomamos de González-Curto (2010) que la utiliza para adherir neuroesferas de cerebro de ratón. Dado que el número de células que observábamos era muy reducido, hicimos una prueba con tres cultivos distintos y cuatro concentraciones de Matrigel diferentes (Fig. 4.29). La concentración final elegida fue de 1:50, ya que ofrecía un número mayor de células fijadas que el de 1:100 y la diferencia con las otras dos concentraciones era despreciable.

\subsubsection{Detección de división celular mediante BrdU}

Al igual que para las secciones, se ha detectado la división de las células mediante el uso de BrdU. Una vez fijadas las neuroesferas a los cubreobjetos, las neuroesferas se incubaron con BrdU a una concentracion de $5 \mu \mathrm{M}$ durante dos horas, para posteriormente realizar una técnica inmunocitoquímica. Como ya se ha señalado en la sección de Material y Métodos, como marcaje de núcleos se ha utilizado Topro3, dado que es un marcaje nuclear que se puede estudiar usando el microscopio confocal. 
Tanto a los 7 días como a los 14 días de cultivo hay células de una misma neuroesfera que han incorporado BrdU en esas dos horas, y por tanto, se han dividido, y otras células que no incorporan BrdU (Fig. 4.30 A y B).

Este experimento nos permite demostrar que el aumento en el diámetro de las neuroesferas medido anteriormente (Fig. 4.27) se debe a que hay división celular y no únicamente a adhesión entre neuroesferas.

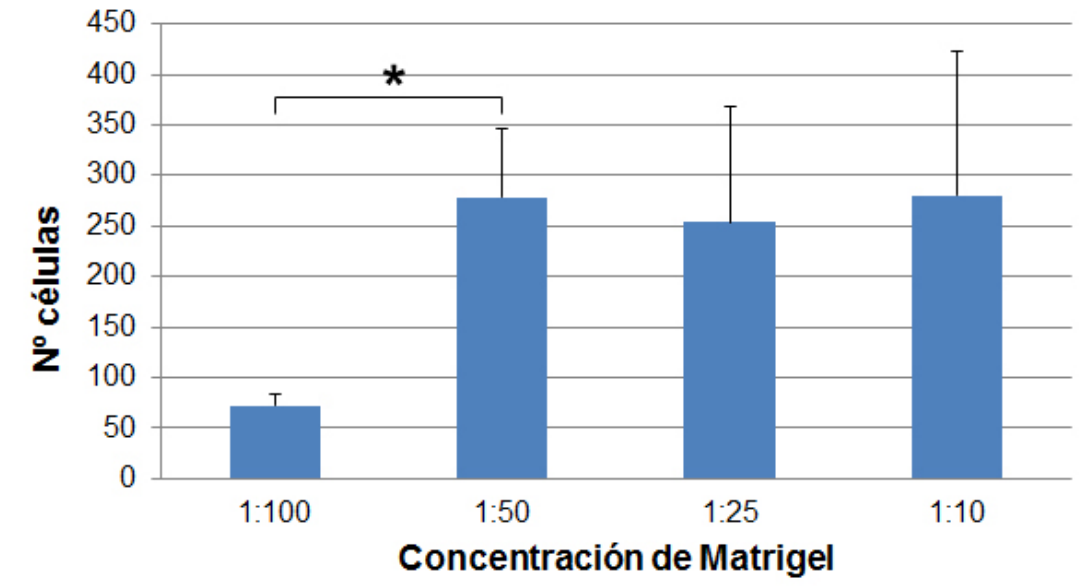

Figura 4.29: Histograma de la relacion del número de células con la concentración de Matrigel. Entre la concentración de 1:100 y la de 1:50 la diferencia es significativa $(\mathrm{p}<0,05)$. Entre el resto de concentraciones no hay diferencias. Barras correspondientes a la desviación estándar. 


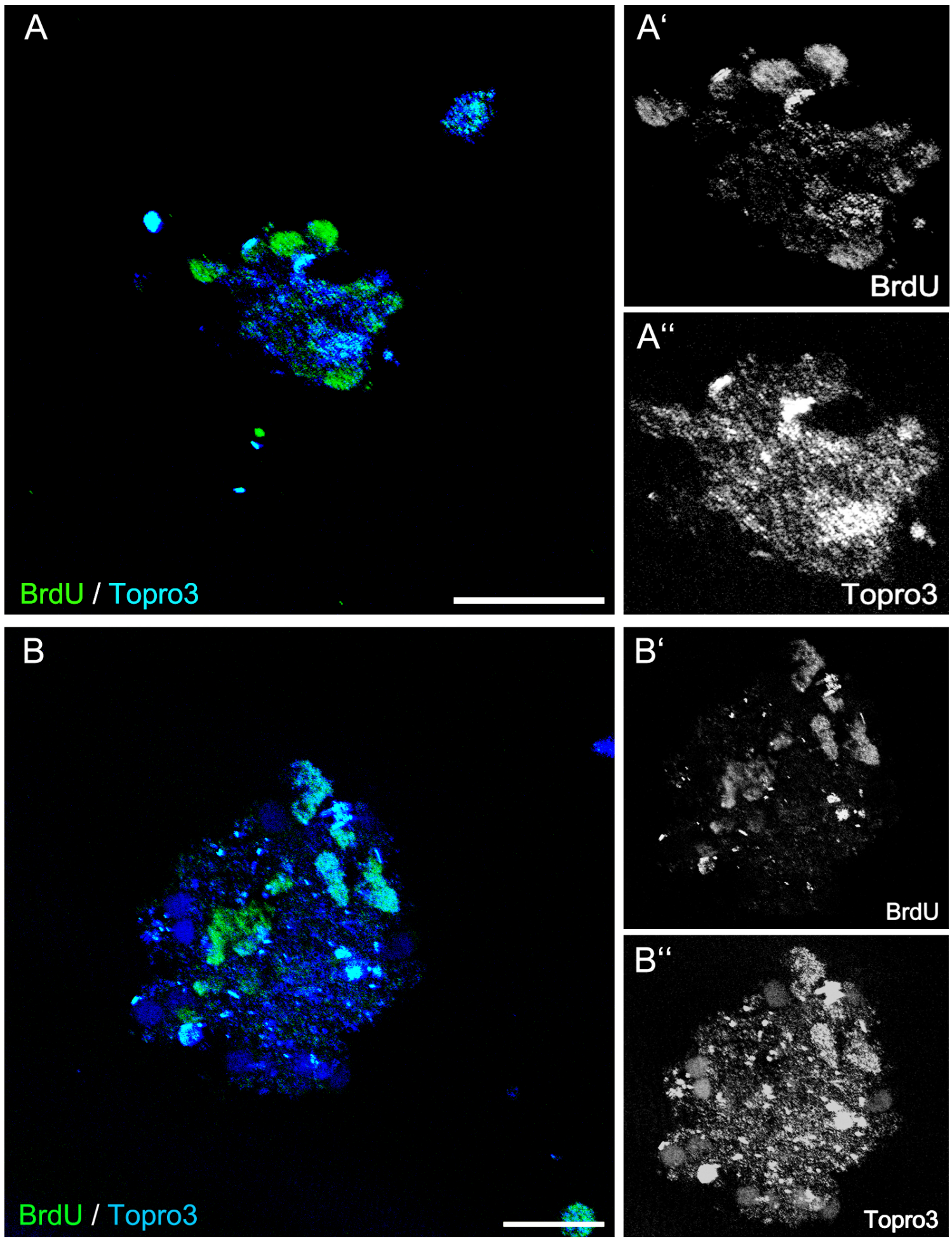

Figura 4.30: Imagen de microscopía confocal de una neuroesfera marcada con BrdU y Topro3 a los 7 días en cultivo (A, A' y A") y a los 14 días (B, B' y B"). A', A", B' y B" son ampliaciones de los dos canales por separado. Barra de escala: $20 \mu \mathrm{m}$. 


\subsubsection{Expresión de Prox1}

Prox1 se expresa en un grupo de células dentro de las neuroesferas obtenidas en cultivo a los 7 días (Fig. 4.31 A) y a los 14 días (Fig. 4.31 B). A los 7 días es más complicado encontrar células positivas para Prox1 que a los 14 días. En este último tiempo de cultivo, Prox1 se expresa tanto en el núcleo de algunas células (Fig. 4.31 B, flecha amarilla) como en el citoplasma (Fig. 4.31 B, punta de flecha).

Para comprobar si se había producido alguna modificación en la proteína, realizamos la técnica de Western Blot y sólo observamos una banda correspondiente al peso normal de la proteína, 83kDa (Fig. 4.32 A).

\subsubsection{Expresión de Pax6}

Algunas células de las neuroesferas de 7 días en cultivo (Fig. $4.33 \mathrm{~A}$ ) y de las de 14 días (Fig. 4.33 B) expresan Pax6. No todas las células expresan el marcador, y este se encuentra principalmente en el citoplasma.

Se realizó la técnica de Western Blot con el anticuerpo anti-Pax6 para demostrar su especificidad. Obtuvimos dos bandas de dos pesos moleculares distintos, que se corresponden con distintas formas de la proteína, siendo la más pequeña la forma citoplasmática (Fig. 4.32 B).

\subsubsection{Expresión de Sox2}

El factor de transcripción Sox2 se expresa en las neuroesferas obtenidas tras 7 y 14 días en cultivo (Fig. 4.34). Mientras que a los 7 días, la localización se restringe al citoplasma (Fig. 4.34 A), en las neuroesferas de 14 días (Fig. 4.34 B) hay Sox2 tanto en el núcleo como en el citoplasma.

Se comprobó mediante Western Blot la especificidad del anticuerpo y se obtuvieron dos bandas de dos pesos moleculares distintos. La banda con menor peso molecular se corresponde con la proteína en condiciones normales $(34 \mathrm{kDa})$, y la de mayor peso con la forma sumoilizada (55kDa) (Fig. $4.32 \mathrm{C}$ ). 

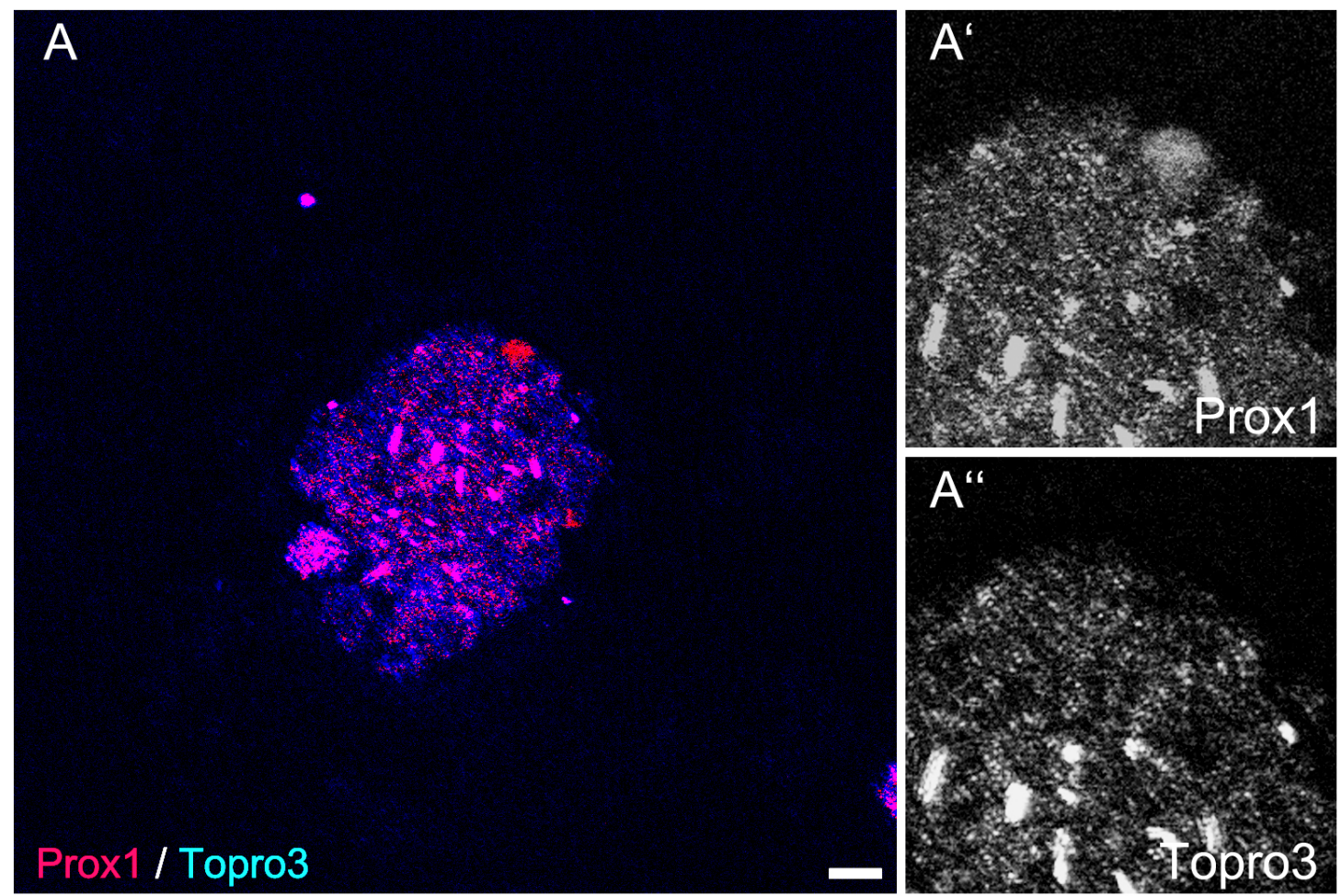

B
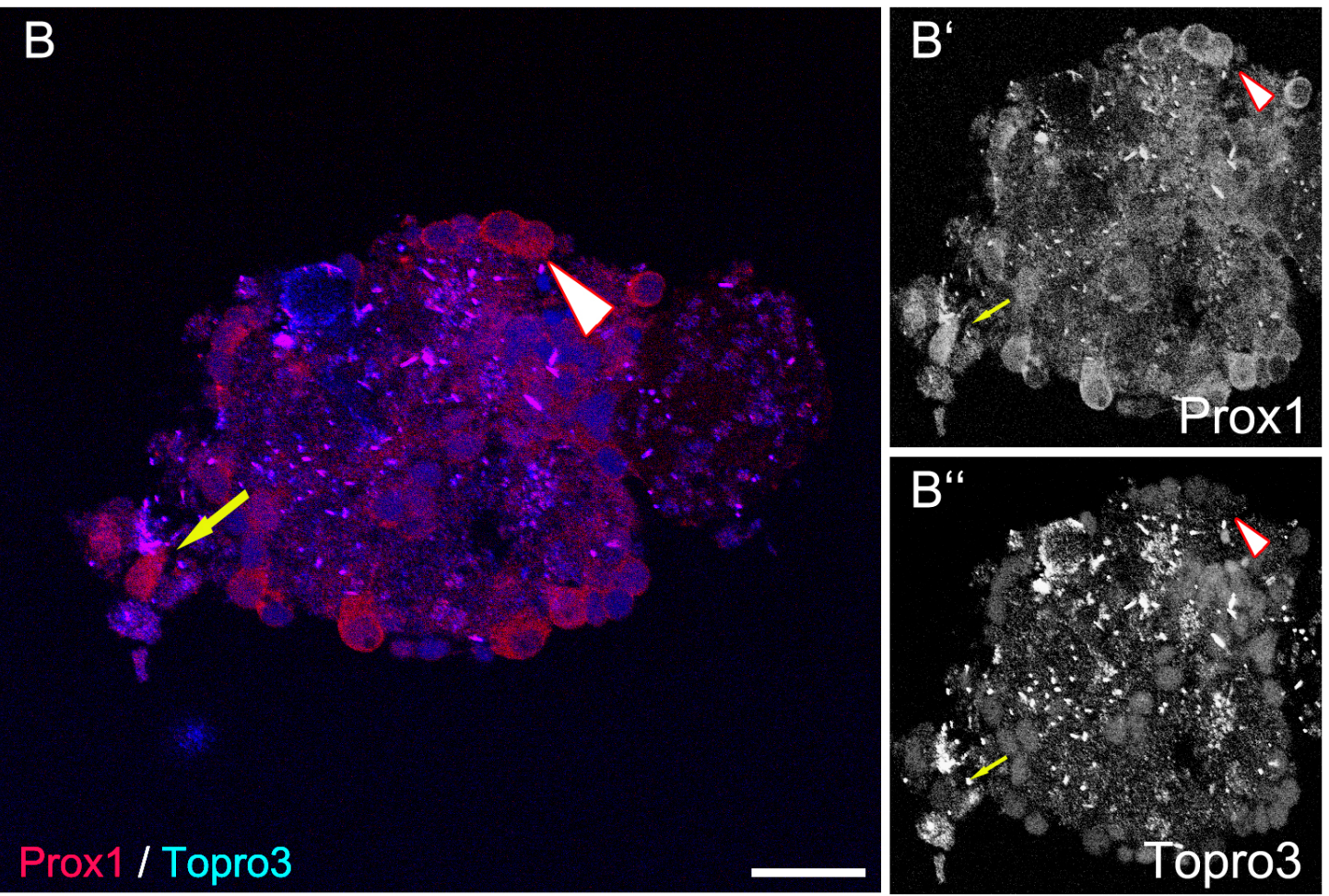

Figura 4.31: Neuroesferas marcadas con Prox1 y Topro3 como marcador nuclear, a los $\mathbf{7}$ (A, A' y A") y 14 días (B, B' y B") en cultivo. A 14 días observamos tanto marcaje nuclear (flecha amarilla) como marcaje citoplasmático (punta de flecha). A', A", B' y B" son ampliaciones de los dos canales por separado. Barra de escala: $20 \mu \mathrm{m}$. 
A

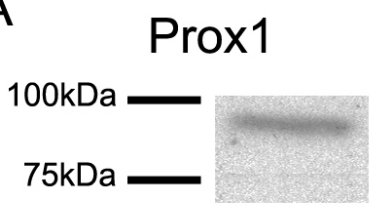

B

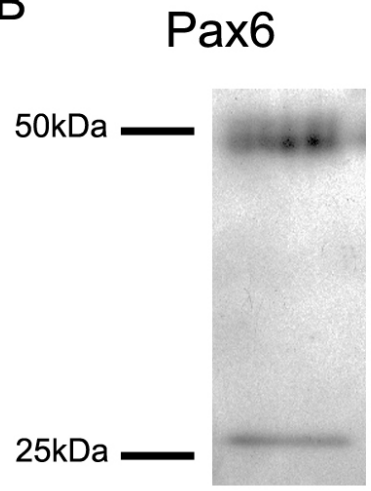

C

Sox2

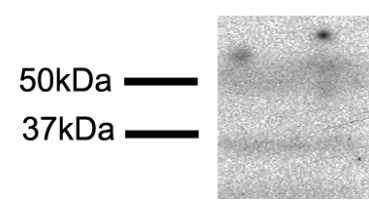

Figura 4.32: Western Blot con los anticuerpos Prox1 (A), Pax6 (B) y Sox2 (C). En el Western Blot de Prox1 (A) se detecta una única banda de unos $80 \mathrm{kDa}$, mientras que para los otros dos anticuerpos se observan dos bandas (B y C). En Pax6 vemos una banda de alrededor de $48 \mathrm{kDa}$ y otra de unos $33 \mathrm{kDa}$ (B). En Sox2 las bandas pesan $34 \mathrm{y}$ $55 \mathrm{kDa}(\mathrm{C})$. 

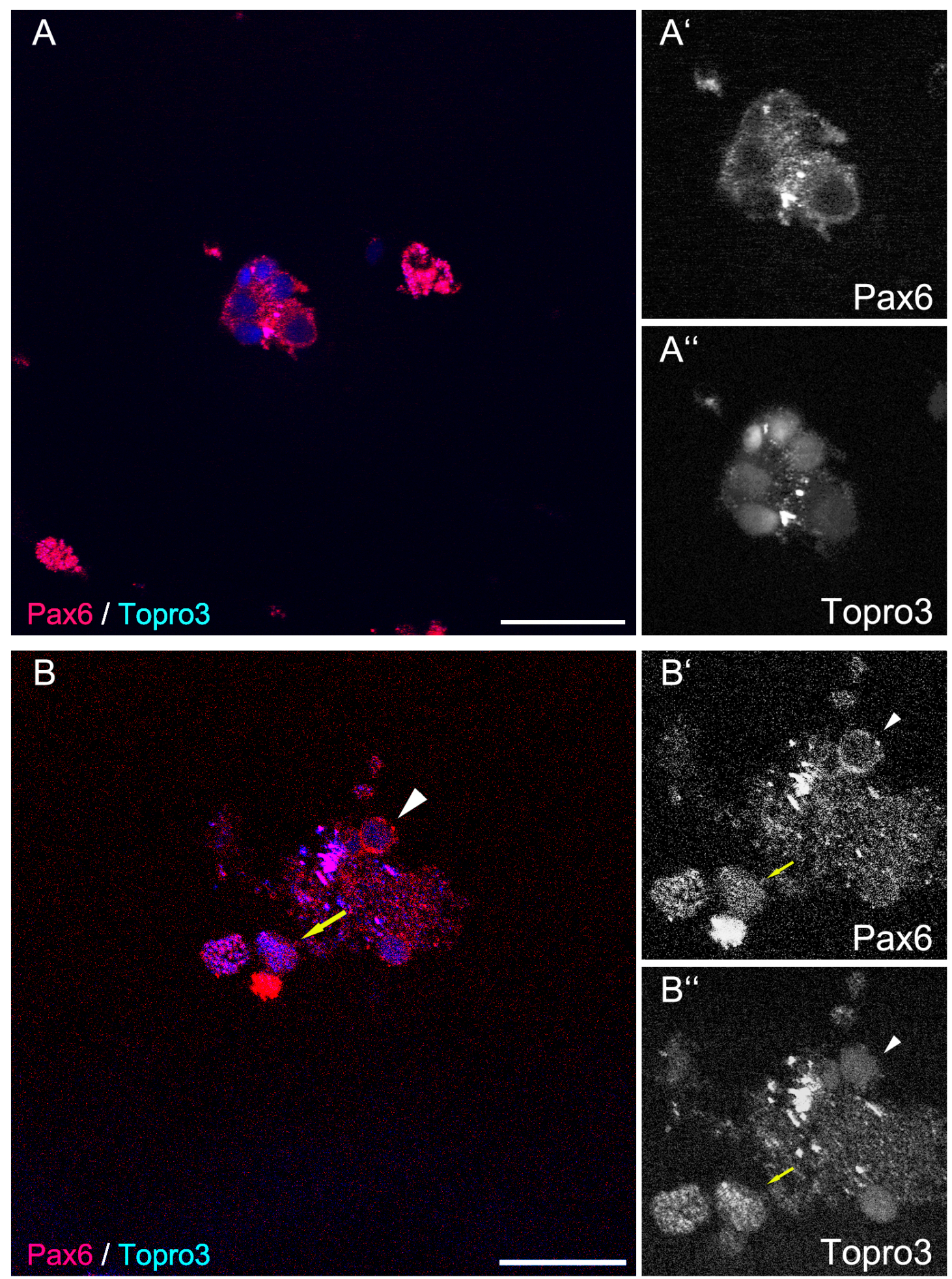

Figura 4.33: Neuroesferas marcadas por la técnica inmunocitoquímica para Pax6, tanto a los 7 días (A, A', A"), como a los 14 días (B, B', B") en cultivo. A los 14 días hay células marcadas con Pax6 en el núcleo (flecha amarilla), y células que expresan Pax6 en el citoplasma (punta de flecha). A', A", B' y B" son ampliaciones de los dos canales por separado. Barra de escala: $20 \mu \mathrm{m}$. 

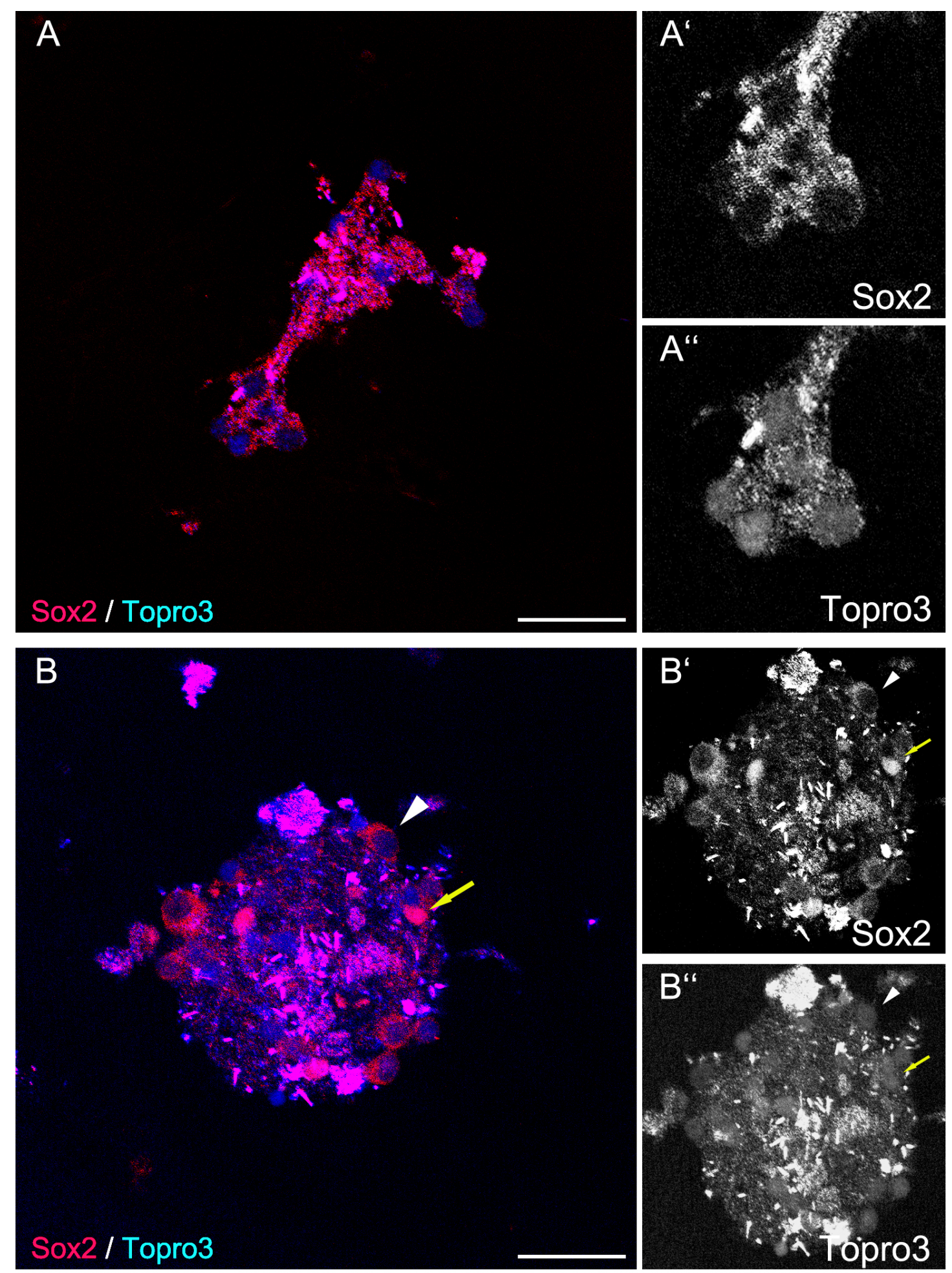

Figura 4.34: Inmunocitoquímica para Sox2 en neuroesferas de 7 días (A, A', A") y 14 días (B, B', B") in vitro. A los 14 días hay células que expresan Sox2 en el citoplasma (punta de flecha) y en el núcleo (flecha amarilla). A', A", B' y B" son ampliaciones de los dos canales por separado. Barra de escala: $20 \mu \mathrm{m}$. 


\subsection{Diferenciación de las neuroesferas}

El estudio de diferenciación de las neuroesferas se realizó retirando los factores de crecimiento (EGF y FGF) del medio de cultivo a los 7 días, y manteniéndolos así durante 7 días más. Para comprobar la diferenciación realizamos una técnica inmunocitoquímica utilizando Sox2, como marcador de las células indiferenciadas, y calretinina (CR) como marcador de diferenciación. Tras 7 días sin factores de crecimiento hay expresión de CR en alguna de las células de las neuroesferas (Fig. 4.35 A), sin observarse dicho marcaje en los controles realizados a partir de cultivos con factores de crecimiento (Fig. 4.35 B). En ningún caso hay colocalización entre ambos marcadores. 

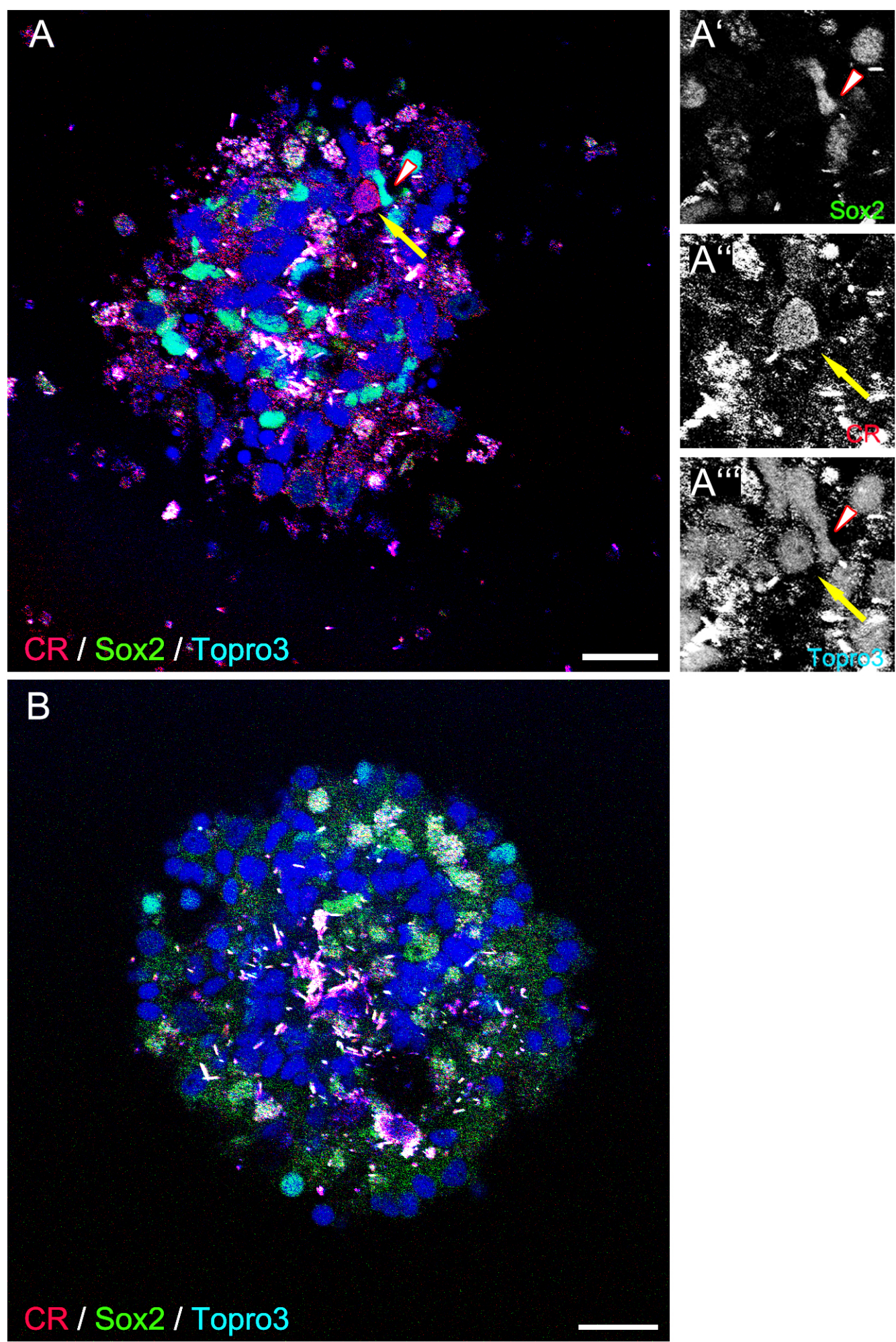

Figura 4.35: Doble immunocitoquímica para Sox2 y CR en esferas en diferenciación (A y detalle de cada uno de los canales en A', A" y A"') y en situación control (B). Hay expresión de CR sólo en la condición de diferenciación (flecha amarilla), pero nunca colocaliza con Sox2 (cabeza de flecha). Barra de escala: $200 \mu \mathrm{m}$. 
4. Resultados 
Capítulo 5

\section{Discusión}


5. Discusión 


\subsection{Estudio de la proliferación celular}

Mediante la inyección de BrdU y un posterior revelado con la técnica inmunohistoquímica, hemos determinado las zonas proliferativas en la retina del pez cebra (Fig. 4.1) y la tasa de proliferación de dichas células (Fig. 4.4).

En el pez cebra se describen dos poblaciones distintas de células proliferativas, la zona periférica germinal (ZPG) y la retina central, donde se encuentra el linaje de bastones.

En la retina central hay células que incorporan BrdU prácticamente en todas las capas, aunque con una mayor proporción en las capas nucleares interna y externa (Fig. 4.1 A y B). Estudios anteriores indican que las células con capacidad proliferativa en la región de la retina central, conforman una población de células que dan lugar exclusivamente a bastones (Johns y Fernald, 1981; Johns, 1982; Raymond, 1985), aunque esta población es también capaz de regenerar todas las capas celulares ante una lesión (Otteson et al., 2001; Wu et al., 2001; Yurco y Cameron, 2005; Thummel et al., 2008). Los progenitores de bastón se pueden dividir en tres subtipos de células según su localización y su morfología (Hoke y Fernald, 1997; Mack et al., 2003; Hitchcock et al., 2004). Así, se puede diferenciar entre las células de la capa vitreal de la CNI, correspondientes a lo que se denominan progenitores de la CNI, las células de la zona escleral de la CNI y de la CPE, que son los progenitores en migración, y por último las células de la CNE, que se corresponden con los precursores de bastón. La morfología varía entre las células pequeñas y redondeadas en la CNI, las alargadas que conforman el grupo de las células en migracion y las redondeadas de mayor tamaño en la CNE. Se ha descrito que las células migran desde la CNI hasta la CNE utilizando los procesos de las células de Müller (Julian et al., 1998; Mack et al., 2003). Estas distintas subpoblaciones coinciden con las descritas en otros trabajos desarrollados anteriormente en el pez cebra (Raymond et al., 2006) y en otras especies como el carpín (Otteson et al., 2001; Wu et al., 2001; Sánchez-González, 2009) o los salmónidos (Julian et al., 1998; Candal et al., 2005). El único pez teleósteo estudiado en el que no se han encontrado progenitores en la CNI es el cíclido Haplochromis burtoni (Mack et al., 2003). Se ha discutido la procedencia de los progenitores de bastón, ya que tradicionalmente se consideraba que provenían de la ZPG (Otteson et al., 2001; Otteson y Hitchcock, 2003), 
pero trabajos recientes proponen que se trata de células de Müller con capacidad de desdiferenciarse (Bernardos et al., 2007; Kassen et al., 2008; Craig et al., 2010).

En la periferia de la retina, las células marcadas con BrdU son células de la ZPG con morfología alargada (Fig. 4.1 C y D). Estas células, similares al neuroepitelio embrionario, dan lugar a todas las neuronas de la retina a excepción de los bastones (Hitchcock et al., 2004). A partir de esta población celular la retina de los peces crece durante toda la vida del animal. Los resultados obtenidos son comparables con observaciones anteriores en el pez cebra(Marcus et al., 1999; Raymond et al., 2006) así como en otras especies de teleósteos como la trucha (Lyall, 1957; Schmitt y Kunz, 1989); el carpín (Johns, 1977; Meyer, 1978; Sánchez-González, 2009) y la carpa (Kock, 1982; Negishi et al., 1985). Esta región es también similar a la existente en anfibios (Hollyfield, 1968; Perron et al., 1998; Hitchcock et al., 2004) y en pollos (Fischer y Reh, 2000; Kubota et al., 2002). Tal y como se describe en la Introducción (ver 1.2.2), en mamíferos hay una zona similar a la ZPG aunque más reducida que tendría células progenitoras, si bien hasta ahora sólo se ha demostrado su existencia y potencialidad en experimentos in vitro (Ahmad et al., 2000; Tropepe et al., 2000; Coles et al., 2004; Mayer et al., 2005; Martínez-Navarrete et al., 2008).

Dado que en la ZPG se generan todos los tipos neuronales excepto los bastones, la zona más externa de la retina está formada sólo por conos como células fotorreceptoras. Sorprendentemente, se sabe que estos conos no expresan las opsinas funcionales hasta no encontrarse con los bastones en una zona más central (Stenkamp et al., 1997; Stenkamp, 2007)

Tal y como se ha mencionado anteriormente en la sección de Resultados, encontramos también células que incorporan BrdU en la CPI y en la CCG (Fig. 4.1). Consideramos que éstas son células gliales, ya que en estas capas son las únicas células que se han descrito con capacidad de división (Salvador-Silva et al., 2000).

La división de las células para dar lugar a nuevas neuronas plantea una cuestión importante relativa al mantenimiento de la función visual y la retinotopía. Se sabe que no sólo la retina genera nuevas neuronas a lo largo de la vida, sino que también hay progenitores en el techo óptico (Raymond y Easter, 1983; Marcus et al., 1999; Ito et al., 2010). La localización de las nuevas células en cada una de las zonas no concuerda exactamente con las conexiones que se forman entre ellas. Mientras que 
5.1. Estudio de la proliferación celular

en la retina las nuevas neuronas se forman en círculos concéntricos en la periferia, el techo óptico crece por adición de nuevas neuronas en la zona mediocaudal (Raymond y Easter, 1983; Cerveny et al., 2012). Se ha propuesto que los terminales de las células ganglionares se mueven por la superficie del techo óptico para mantener la retinotopía, a la vez que aumenta el campo receptivo de las neuronas (Easter et al., 1977; Easter y Stuermer, 1984; Cerveny et al., 2012). Además, la tasa de producción de nuevas neuronas está regulada por el aumento del tamaño general del animal, especificado a su vez por el eje de la hormona de crecimiento (GH, de sus siglas en inglés) y el factor de crecimiento similar a la insulina (IGF, de sus siglas en inglés) (Mack y Fernald, 1993; Boucher y Hitchcock, 1998; Otteson et al., 2002; Stenkamp, 2007).

\subsubsection{Estudio cuantitativo de la tasa de división de los pro- genitores}

Para contabilizar el número de células que se dividen a lo largo del tiempo, hemos realizado una única inyección intraperitoneal de BrdU, y estudiado las células que han incorporado el compuesto tras distintos tiempos de supervivencia (Fig. 4.4).

Los estudios que se han realizado hasta el momento en el que se contabilizan las células en división se han hecho teniendo en cuenta la respuesta a distintos factores: adición de IGF-I (factor de crecimiento insulínico I): (Mack y Fernald, 1993; Boucher y Hitchcock, 1998; Otteson et al., 2002); variación de temperatura: (Velasco et al., 2001); distintas condiciones de luz/oscuridad: (Chiu et al., 1995; Kwan et al., 1996; Julian et al., 1998). Además, se han contabilizado las células que se dividen en distintas especies de teleósteos (Cid et al., 2002). En todos estos estudios, se han marcado las células en división utilizando timidina tritiada, PCNA o por inmersión en BrdU durante al menos 16 horas.

Hinsch y Zupanc (2006) han utilizado un procedimiento similar al empleado por nosotros, inyectando BrdU intraperitonealmente. Sabiendo que el metabolismo de la BrdU es de 30 minutos (Packard et al., 1973; Böswald et al., 1990), podemos afirmar que cualquier aumento en el número de células positivas para BrdU es debido a sucesivas divisiones de las que incorporaron la BrdU durante ese periodo. En nuestro desarrollo experimental, en cualquier periodo de 30 minutos hay una media de 2,28 
células en división en la ZPG, 1,17 células en la CNE y 0,04 células en la CNI por cada sección de retina de $10 \mu \mathrm{m}$. De esto se deduce que la tasa de división de las células de la ZPG es superior a la del resto de las zonas, tomada en cualquier periodo de 30 minutos. Por el contrario, hemos comprobado que tras periodos post-inyección de 4 horas y de 1 día, el número de células positivas a BrdU es superior en la retina central. Consideramos que este cambio es debido a la alta tasa de división en la ZPG, que hace que cierto número de células que se han dividido pierdan el marcaje; además ha de considerarse el paso contínuo de células a la zona de transición y posteriormente a la zona central de la retina. En la retina central la división es más lenta y por tanto la pérdida de marcaje debido a las sucesivas divisiones no se da con tanta intensidad como en la ZPG. Se conoce por estudios anteriores que se produce un pico de división en la capa nuclear externa hacia la mitad de la fase oscura en un ciclo de luz/oscuridad de 12 horas (Chiu et al., 1995; Kwan et al., 1996; Julian et al., 1998; Stenkamp, 2007). Esto estaría asociado con el gran número de células en la retina central el primer día tras la inyección (Fig. 4.4 A).

Hemos estudiado la evolución de las células progenitoras hasta los 28 días post inyección, y en el resto de zonas, con excepción de la CNI, hay células marcadas. Dado que no observamos células marcadas en la CNI, muchas de las células de la retina central se dividieron anteriormente en la CNI y tras migrar a la CNE se vuelven a dividir. Hinsch y Zupanc (2006) demuestran la presencia de células positivas a BrdU en el cerebro del pez cebra hasta 1010 días post inyección. Aunque en el cerebro hay más nichos de división, se puede suponer que en la retina se podrían detectar células marcadas en tiempos posteriores a los considerados en este estudio, ya que una vez que las células de la retina se diferencian, el marcaje se mantiene. La esperanza de vida media de un pez es de unos 4,3 años (Gerhard et al., 2002), así que es posible que se puedan observar células hasta el final de la vida del animal. 
5.2. Caracterización de los progenitores retinianos

\subsection{Caracterización de los progenitores retinia- nos}

\subsubsection{Prox1}

\section{Expresión de Prox1 en la retina adulta}

El gen Prox1 es fundamental para el correcto desarrollo del ojo (Dyer et al., 2003; Cid et al., 2010). En este trabajo hemos descrito que Prox1 se expresa en la CNI y la CCG de animales adultos, además de en la ZPG (Fig. 4.6). Para la localización inmunohistoquímica de este factor de transcripción, al igual que para todos los marcadores inmunocitoquímicos utilizados en este trabajo, las secciones se revelaron por el método ABC, además de con distintos fluorocromos. La razón para la utilización de ambos métodos es que las secciones reveladas mediante la técnica de $\mathrm{ABC}$ tienen por lo general una mayor intensidad de marcaje, dado que se amplía la señal mediante el complejo avidina-biotina-peroxidasa, mientras que el marcaje con fluorescencia permite realizar dobles marcajes.

Se han realizado numerosos estudios de expresión de Prox1 en retina de anfibios (Del Rio-Tsonis et al., 1999; Makariev et al., 2002), aves (Tomarev et al., 1996; Belecky-Adams et al., 1997; Edqvist y Halböök, 2004) y diferentes especies de mamíferos (Tomarev et al., 1998; Dyer et al., 2003); pero los estudios en la retina de peces adultos son escasos (Cid, 2006; Sánchez-González, 2009; Cid et al., 2010). Los estudios realizados en teleósteos se limitan generalmente a la expresión del factor de transcripción durante la retinogénesis del pez cebra (Vihtelic et al., 2001; Godinho et al., 2007; Cid et al., 2010), del pez de cueva Astyanax mexicanus (Jeffery et al., 2000) y del medaka Oryzias latipes (Deguchi et al., 2009).

Por su situación y su morfología consideramos que las células positivas a Prox1 situadas en la zona más escleral de la CNI son células horizontales (Fig. 4.6 A y C), hecho que concuerda con estudios realizados en el carpín y la tenca (Cid, 2006; Sánchez-González, 2009; Cid et al., 2010), durante la retinogénesis del pez cebra (Vihtelic et al., 2001) y en la retina de otros grupos animales como los anfibios (Del Rio-Tsonis et al., 1999; Makariev et al., 2002), las aves (Tomarev et al., 1996; Belecky-Adams et al., 1997; Edqvist y Halböök, 2004; Edqvist et al., 2006; Fischer 
et al., 2007) y los mamíferos (Tomarev et al., 1998; Dyer et al., 2003; Cid et al., 2010). Las otras células de la CNI que expresan Prox1, que se sitúan en la zona central, podrían ser células bipolares, y las de la zona más vitreal células amacrinas (Fig. 4.6 A, C y D). Esto es congruente con los estudios que indican que Prox1 influye en la diferenciación de ambos tipos de células (Dyer et al., 2003). Además, se ha demostrado que también las células de Müller expresan Prox1 (Cid et al., 2010). Como hemos señalado, hay expresión de Prox1 en la CCG. La descripción de células de la CCG positivas para Prox1, se realizó por primera vez en tritones (Del Rio-Tsonis et al., 1999; Markitantova et al., 2003); pero actualmente hay datos que sugieren la presencia de dicho marcador también en células de la CCG del pez de cueva (Jeffery et al., 2000), del carpín (Sánchez-González, 2009; Cid et al., 2010), de la tenca (Cid, 2006) e incluso del ratón (Cid et al., 2010). Teniendo en cuenta que no se ha descrito la expresión de Prox1 en la generación de células ganglionares, y que el número de células amacrinas desplazadas en la CCG es considerable, sugerimos que las células positivas a Prox1 en la CCG son amacrinas desplazadas. Del mismo modo, las células Prox1 positivas de la CPI pueden corresponder también a células amacrinas desplazadas.

Hasta donde sabemos, los estudios relacionados con la expresión de Prox1 en la ZPG se reducen a un trabajo realizado en el tritón (Markitantova et al., 2003), donde por hibridación in situ de describe una expresión intensa de Prox1 en la ZPG, y otros dos en el carpín (Sánchez-González, 2009; Cid et al., 2010) realizados en nuestro laboratorio. Dichos resultados coinciden con los de este trabajo. Dado que Prox1 está implicado en la diferenciación de distintos tipos celulares de la retina, no sorprende que al menos alguna de las células de la ZPG expresen el marcador. El número de células marcadas con Prox1 en la ZPG de la retina adulta del pez cebra no es muy numeroso, coincidiendo con los resultados del carpín (Cid et al., 2010) y con el hecho de que, durante la retinogénesis, en ratones tan sólo un 3-8\% de los retinoblastos expresan Prox1 (Dyer et al., 2003).

\section{Colocalización de Prox1 con BrdU}

Con respecto a la colocalización de las células Prox1 positivas con BrdU, nuestros resultados muestran células positivas para ambos marcadores tanto en la ZPG como en la retina central (Fig. 4.7). En la retina central observamos células progenitoras 
que expresan Prox1 situadas principalmente en la capa más vitreal de la CNI. Los estudios que han demostrado que Prox1 puede estar implicado en la generación de bastones son escasos (Cid, 2006; Sánchez-González, 2009; Cid et al., 2010). De hecho, esos resultados no concuerdan con lo descrito en la retina de ratón, donde los progenitores retinianos postnatales no expresan Prox1 (Dyer et al., 2003). Hemos observado también células positivas para Prox1 y BrdU en la CCG. Es posible que estas células, descritas también en el carpín (Sánchez-González, 2009), sean gliales, ya que son el único grupo celular con capacidad de división que se sitúa en dicha capa. En apoyo de lo anterior, conviene resaltar que ya se ha descrito la expresión de Prox1 tanto en células gliales en el cerebro de Drosophila melanogaster (Hidalgo y Griffiths, 2004) como en el giro dentado del ratón (Lavado y Oliver, 2007).

El número de células que son positivas para Prox1 y BrdU es escaso en la ZPG. Esto concuerda con otros estudios realizados en el carpín (Sánchez-González, 2009; Cid et al., 2010) y la tenca (Cid, 2006). Teniendo en cuenta la implicación de Prox1 en la retinogénesis y en particular el proceso de diferenciación de tipos neuronales concretos (Cook et al., 2003; Dyer et al., 2003; Edqvist y Halböök, 2004), podemos postular que se trata de progenitores de células horizontales, amacrinas o bipolares, tanto en división como en proceso de diferenciación.

\subsubsection{Pax6}

Pax6 juega un papel fundamental en la salida del ciclo celular, y por tanto en la proliferación de las células progenitoras retinianas (Hsieh y Yang, 2009). Es necesaria la expresión de Pax6 en los progenitores para mantener su multipotencialidad (Marquardt et al., 2001) y la capacidad de proliferación (Xu et al., 2007b), aunque cuando las células comienzan a diferenciarse, Pax6 ya no es necesario para el mantenimiento de la estirpe celular (Marquardt et al., 2001). Pax6 es responsable de activar los genes $b H L H$ encargados de la determinación de distintos tipos celulares retinianos (Hirsch y Harris, 1997). Cuando una célula troncal se divide asimétricamente genera por un lado un progenitor negativo a Pax6, que migrará y dará lugar a una célula madura, y por otro a una célula Pax6 positiva que mantiene la población de células troncales inmaduras (Weissman, 2000). 


\section{Expresion de Pax6 en la retina adulta}

En el pez cebra, el factor de transcripción Pax6 se localiza en la CNI y la CCG de la retina adulta, además de en la ZPG (Fig. 4.9). Esta proteína es imprescindible para el desarrollo correcto del ojo, habiéndose realizado numerosos estudios tanto durante la retinogénesis (Del Rio-Tsonis et al., 1995; Altmann et al., 1997; Hirsch y Harris, 1997; Nornes et al., 1998; Kaneko et al., 1999; Ziman et al., 2001; Bäumer et al., 2003; Alunni et al., 2007; Ferreiro-Galve et al., 2012), como en la retina adulta (Hitchcock et al., 1996; Otteson et al., 2001; Faillace et al., 2002; Cid, 2006; Ferreiro-Galve et al., 2012). Se ha postulado que una de las funciones de Pax6 durante la retinogénesis es la diferenciación tardía de células amacrinas, horizontales y ganglionares (Kawakami et al., 1997). Además, en células en cultivo, Pax6 se expresa en células ganglionares y amacrinas diferenciadas (Amirpour et al., 2012).

En diversos estudios se describe la presencia de células Pax6 positivas en la CNI de la retina de teleósteos y de otros grupos animales, incluidos los humanos (Krauss et al., 1991; Hitchcock et al., 1996; Callaerts et al., 1997; Hirsch y Harris, 1997; Nishina et al., 1999; Otteson et al., 2001; Strickler et al., 2001; Ziman et al., 2001; Faillace et al., 2002; Cid, 2006; Alunni et al., 2007; Sánchez-González, 2009; Ferreiro-Galve et al., 2012), al igual que observamos nosotros en el pez cebra . Por su localización y su expresión conjunta con marcadores específicos se ha propuesto que se trata de células amacrinas (Hitchcock et al., 1996; Fischer et al., 2006; FerreiroGalve et al., 2012).

Pax6 se expresa en las células ganglionares durante la retinogénesis, tanto de tiburones (Ferreiro-Galve et al., 2012) y de peces teleósteos (Krauss et al., 1991; Püschel et al., 1992; Hitchcock et al., 1996; Strickler et al., 2001), como de anfibios (Hirsch y Harris, 1997) y de aves (Edqvist et al., 2006; Hsieh y Yang, 2009). Está también presente en la CCG de animales adultos, coincidiendo los datos aportados en nuestro trabajo con estudios anteriores en animales desde los teleósteos a los mamíferos (Krauss et al., 1991; Hitchcock et al., 1996; Callaerts et al., 1997; Hirsch y Harris, 1997; Nishina et al., 1999; Otteson et al., 2001; Strickler et al., 2001; Ziman et al., 2001; Faillace et al., 2002; Cid, 2006; Alunni et al., 2007; Sánchez-González, 2009; Ferreiro-Galve et al., 2012). Los núcleos de las células marcadas tienen diferente intensidad de marcaje, y se ha postulado que puede tratarse tanto de células ganglionares como de células amacrinas desplazadas (Hirsch y Harris, 1997). 


\section{Colocalización de Pax6 con BrdU}

Los resultados obtenidos en este trabajo demuestran que hay colocalización de Pax6 con BrdU tanto en la ZPG como en la CNI de la retina central (Fig. 4.10).

En la ZPG observamos células fusiformes positivas a Pax6 y BrdU. Estas células se han descrito también en otras especies de teleósteos y anfibios (Hitchcock et al., 1996; Perron et al., 1998; Kaneko et al., 1999; Fischer y Reh, 2000; Faillace et al., 2002; Kubota et al., 2002; Cid, 2006; Sánchez-González, 2009). La colocalización de ambos marcadores en células de la ZPG no es muy sorprendente ya que son células muy indiferenciadas.

La colocalización en las células de la CNI se produce únicamente en la capa más vitreal. Estos resultados son congruentes con otros estudios realizados anteriormente en el carpín (Otteson et al., 2001; Sánchez-González, 2009), la trucha (Faillace et al., 2002) y el pez cebra (Raymond et al., 2006). Se trata de células redondeadas positivas a Pax6 y BrdU que forman una fila, tienen una baja tasa proliferativa, y se las ha descrito como los progenitores del linaje de bastones de la CNI. Nosotros no hemos observado colocalización en ninguna otra célula, coincidiendo con lo descrito por otros autores (Hitchcock et al., 1996; Otteson et al., 2001; Faillace et al., 2002; Raymond et al., 2006).

\subsubsection{Sox 2}

Sox2 es un factor de transcripción implicado en el mantenimiento del estado indiferenciado de las células progenitoras. Según estudios precedentes, esta función se realiza mediante la interferencia en la función de los genes bHLH, que son los implicados en la diferenciación celular (Bylund et al., 2003). A su vez, los genes bHLH regulan negativamente a Sox2 para que se pueda dar la salida del ciclo celular y se proceda a la diferenciación neuronal (Fig. 5.1). Se conoce, además, que la combinación de Sox 2 con Oct4 es esencial para el mantenimiento de la forma indiferenciada, mediante la activación de genes ligados a la pluripotencialidad (Avilion et al., 2003). A pesar de esto, Sox2 no es capaz de promover la proliferación por sí mismo (Bylund et al., 2003; Agathocleous et al., 2009). En las células retinianas, los niveles de Sox2 regulan la elección entre el mantenimiento de la identidad de 
las células progenitoras y la diferenciación, mediante la interacción con el factor de transcripción Notch1 (Taranova et al., 2006).

Sox2 está regulado positivamente entre otras proteínas por Prox1 y Pax6 (Lengler et al., 2005), posiblemente mediante la unión al promotor N3 de Sox2 (Inoue et al., 2007) (Fig. 5.1). Por su parte, Sox2 activa la transcripción de Pax6 (Lin et al., 2009). Además, cabe destacar que tanto Pax6 como Sox2 son necesarios para la producción de las señales iniciadoras de la morfogénesis del ojo (Smith et al., 2009). Entre estos dos marcadores, como es lógico por su interacción, se ha observado colocalización en células de la retina de ratones, tanto en desarrollo (Hever et al., 2006; Lin et al., 2009; Matsushima et al., 2011) como en el adulto (Freeman et al., 2011)

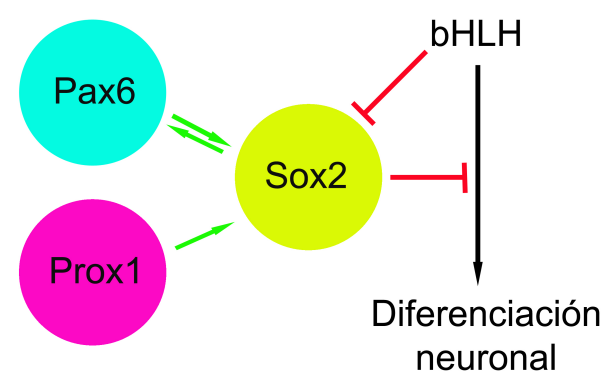

Figura 5.1: Esquema de la función de Sox2 para regular la diferenciación neuronal

\section{Expresión de Sox2 en la retina adulta}

Según nuestros resultados, Sox2 se localiza tanto en la CNI y la CCG de la retina central, como en la ZPG del pez cebra (Fig. 4.11).

Se ha postulado que las células positivas de la CNI pueden ser células amacrinas (Fischer et al., 2010a; Jusuf y Harris, 2009) o células de Müller (Taranova et al., 2006). Sox2 es un factor de transcripción determinante para la diferenciacion de células amacrinas (Rouëdec et al., 2002; Sakagami et al., 2003; Taranova et al., 2006; Lin et al., 2009; Jusuf y Harris, 2009; Fischer et al., 2010a), y se expresa también en este tipo celular en estadios maduros y animales adultos (Rouëdec et al., 2002; Ellis et al., 2004; Taranova et al., 2006; Lin et al., 2009; Fischer et al., 2010a). Se sabe que son células amacrinas ya que colocalizan con distintos marcadores específicos como Islet1, neuropéptido Y o calretinina entre otros (Rouëdec et al., 2002; Taranova et al., 2006). Las otras células de la CNI que expresan Sox2 son las células de Müller, 
como se ha demostrado en aves (Boije et al., 2010; Fischer et al., 2010b), ratones (Taranova et al., 2006; Lin et al., 2009; Fischer et al., 2010a) y humanos (Bhatia et al., 2009). También se localiza Sox2 en células de Müller en cultivo (Lawrence et al., 2007) donde es necesario para su mantenimiento, al menos en células procedentes de humanos (Bhatia et al., 2011). En ratones también se han descrito células positivas a Sox2 en la CCG, que se corresponden con células amacrinas desplazadas (Taranova et al., 2006; Lin et al., 2009).

Los estudios de expresión de Sox2 en la ZPG se reducen a la zona marginal de Xenopus (Agathocleous et al., 2009), y del epitelio ciliar no pigmentado de humanos (Bhatia et al., 2009, 2011; Johnsen et al., 2012). Hasta el momento no hemos encontrado estudios relativos a la retina adulta de teleósteos, pero es lógico pensar que como hemos descrito en la presente Tesis Doctoral la ZPG aparecerá marcada también en otras especies, ya que Sox2 es un marcador de células indiferenciadas.

\section{Colocalización de Sox2 con BrdU}

Sox2 colocaliza con BrdU no sólo en la retina del pez cebra como se ha demostrado en este trabajo (Fig. 4.12), sino que también hay colocalización en otros modelos animales y en otras regiones proliferativas. Sox2 se expresa en varios modelos animales en células progenitoras durante la embriogénesis: pez cebra (Jusuf y Harris, 2009), Xenopus (Raay et al., 2005), aves (Rouëdec et al., 2002; Bylund et al., 2003; Graham et al., 2003) y ratones (Zappone et al., 2000; D'Amour y Gage, 2003; Ellis et al., 2004; Miyagi et al., 2006; Favaro et al., 2009). En animales adultos se conoce la colocalización de Sox2 con BrdU en progenitores del cerebro del pez cebra (Adolf et al., 2006; Kaslin et al., 2009; März et al., 2010), en el cerebro de ratones (Zappone et al., 2000; Ferri et al., 2004) y ratas (Komitova y Eriksson, 2004) y en la médula espinal de humanos (Mothe et al., 2011). Sox2 se expresa junto con Ki67, un antígeno asociado a proliferación, en explantes de retina de ratón embrionario (Lin et al., 2009). Es de suponer que debido a su influencia en el mantenimiento del estado indiferenciado de las células, aparezca colocalizacion de BrdU o de cualquier otro marcador de división celular con Sox2 en todas las células progenitoras con capacidad de división en la retina, como hemos visto en este estudio. 


\subsubsection{Islet1}

Se conoce la implicación del factor de transcripción Islet1 en la diferenciación de células ganglionares, amacrinas, horizontales y bipolares, pero no de fotorreceptores (Galli-Resta et al., 1997; Haverkamp et al., 2003; Shkumatava et al., 2004; Elshatory et al., 2007a; Guduric-Fuchs et al., 2009), aunque el modo de actuación no se conoce con exactitud. Se ha postulado que Islet1 interviene en la división final que dará lugar a una célula positiva para Islet1, que sera la que se diferencie, y una célula negativa para Islet1, que mantendrá su capacidad de división (Pan et al., 2008). Los mutantes para Islet1 generan el número de células correcto pero éstas no se terminan de diferenciar correctamente y mueren por apoptosis (Elshatory et al., 2007a; Pan et al., 2008). Se conoce, además, que Islet1 está implicado en el correcto crecimiento de los axones, aunque los estudios se han centrado principalmente en las motoneuronas (Thor y Thomas, 1997).

Con respecto a la coexpresión con otros marcadores, se dan dos situaciones contradictorias. Se ha descrito colocalización de Islet1 con Sox2, aunque éste sea un marcador de células indiferenciadas (Neves et al., 2007), y con Pax6 en células amacrinas (Elshatory et al., 2007b). Además, Islet1 colocaliza con Prox1 en células horizontales, en los primeros estadios de diferenciación (Edqvist et al., 2008; Suga et al., 2009).

\section{Expresión de Islet1 en la retina adulta}

Según nuestro estudio, Islet1 se expresa en la retina central y en la ZPG del pez cebra (Fig. 4.13).

Islet1 se expresa en células ganglionares maduras de pez cebra (Sherpa et al., 2008), carpín (Sánchez-González, 2009), tenca (Bejarano-Escobar et al., 2009), pollo (Austin et al., 1995), rata (Thor et al., 1991; Galli-Resta et al., 1997); ratón (Elshatory et al., 2007a; Marchena et al., 2011) y cerdo (Guduric-Fuchs et al., 2009). Islet1 se empieza a detectar en las células ganglionares de la retina desde las primeras etapas del desarrollo, y es un gen clave en la diferenciación de dichas células en pez cebra (Masai et al., 2000; Shkumatava y Neumann, 2005; Huang et al., 2009), tortuga (Francisco-Morcillo et al., 2006), pollo (Díaz et al., 2000; Sakagami et al., 
5.2. Caracterización de los progenitores retinianos

2003; Boije et al., 2008), ratón (Elshatory et al., 2007a; Pan et al., 2008; Sun et al., 2009; Prasov y Glaser, 2012) y cerdo (Guduric-Fuchs et al., 2009).

Además de en células ganglionares Islet1 se expresa, tanto en desarrollo como en adultos, en células amacrinas (Galli-Resta et al., 1997; Elshatory et al., 2007a; Boije et al., 2008; Stanke et al., 2008; Bejarano-Escobar et al., 2009; Guduric-Fuchs et al., 2009; Sánchez-González, 2009), horizontales (Edqvist et al., 2006; Fischer et al., 2007; Bejarano-Escobar et al., 2009; Sánchez-González, 2009; Suga et al., 2009) y bipolares (Shkumatava y Neumann, 2005; Edqvist et al., 2006; Guduric-Fuchs et al., 2009; Sánchez-González, 2009). Todo ello es coincidente con nuestros resultados, ya que hay expresión de Islet1 en casi toda la extensión de la CNI.

Las referencias a Islet1 en la ZPG de teleósteos se reduce al estudio en el carpín (Sánchez-González, 2009), donde no se describe la localización de esta proteína en la ZPG. La diferencia observada en estos resultados puede deberse a que en el presente trabajo se estudia la expresión del ARNm y en Sánchez-González (2009) se detectaba la proteína. En la ZPG de pollos, tras una inyección de insulina que estimula la división de las células, también se ha demostrado expresión de Islet1 (Fischer et al., 2002a; Fischer y Reh, 2003).

\section{Colocalizacion de Islet1 con BrdU}

Islet1 y BrdU colocalizan en la retina central del pez cebra y en la ZPG (Fig. 4.14). Estos datos concuerdan con los resultados obtenidos en el carpín (Sánchez-González, 2009). La presencia en estas células parece contraria a la función de Islet1, ya que éste está implicado en la diferenciación siendo un marcador inicial de la misma. Una de las explicaciones posibles es que estas células se hayan dividido durante el proceso de inyección de BrdU, y que en el momento del sacrificio hayan comenzado su diferenciación. Por otro lado, en las primeras etapas de la retinogénesis en ratones hay colocalización de EdU, un análogo de la BrdU, con Islet1 tras un pulso único y realizando el análisis tras una hora (Prasov y Glaser, 2012). En este trabajo se indica la posibilidad de que Islet1 se exprese en las células progenitoras antes de que estas salgan del ciclo celular. Se han obtenido resultados similares en el desarrollo del oido del pollo, donde Islet1 se expresa en células con capacidad de división (Neves et al., 2007). Habrá que realizar otros experimentos orientados a dilucidar la interaccion 
de Islet1 con BrdU en los progenitores retinianos del pez cebra adulto.

\subsubsection{Shh}

La proteína Shh está implicada en la salida del ciclo celular en el desarrollo de la retina del pez cebra (Shkumatava et al., 2004; Masai et al., 2005), y de ratones (Dakubo et al., 2008; Agatholeous y Harris, 2009; Cwinn et al., 2011); aunque en otros contextos estimula la proliferación (Roy y Ingham, 2002). Es posible que en peces adultos promueva la proliferación, ya que se han propuesto distintas funciones para Shh en desarrollo y en el adulto (Takabatake et al., 1997). En pollos, se ha descrito que Shh está implicado en la regeneración de la retina (Spence et al., 2004).

Shh actúa mediante la unión a su receptor Patched. Ésto activa a la proteína transmembrana Smoothened que regula la expresión de factores de transcripción Gli (Ingham et al., 1991; Weitzman, 2002).

En cuanto a la regulación de Shh, se sabe que Sox2 activa a elementos reguladores del gen Shh (Favaro et al., 2009). Además, se ha descrito colocalización de ambos marcadores tanto en el desarrollo como en neuroesferas de ratón en cultivo (Favaro et al., 2009). Los genes SoxE son activados a su vez por la cascada de señalización de Shh y entre ambos influyen en el desarrollo de las células de Müller (McNeill et al., 2012). Otro de los genes relacionados con Shh es Pax6. Shh es un regulador negativo de Pax6 (Ericson et al., 1997; Briscoe et al., 2000; Zhang y Yang, 2001; Fuccillo et al., 2006; Cwinn et al., 2011) en el desarrollo, pero en adultos ambos tienen un patrón de expresión similar en la retina (Takabatake et al., 1997; Moshiri et al., 2005) y en la médula espinal de ratones (Rowitch et al., 1999). La expresión de Shh y de Islet1 en distintas células de la retina permite dividir las células en distintos grupos (Shkumatava et al., 2004). Así, podemos clasificar las células ganglionares en cuatro tipos: las que no expresan ninguna de las dos proteínas, las que expresan ambas y las que expresan una sola de las dos. La relación funcional entre ambas proteínas requerirá futuros estudios. 


\section{Expresión de Shh en la retina adulta}

Sonic hedgehog (Shh) es una proteína secretable clave en la retinogénesis y según nuestros resultados, se expresa en la retina central pero no en la ZPG en el pez cebra adulto (Fig. 4.15).

En la retina adulta del ratón, la proteína Shh se expresa en la CCG y en células de la porción vitreal de la CNI (Jensen y Wallace, 1997; Takabatake et al., 1997) al igual que en nuestro estudio, donde Shh se expresa en la CCG y en toda la extensión de la CNI, con células intensamente marcadas en la parte más vitreal (Fig. 4.15). También hay expresión de Shh en la retina adulta de anfibios (Takabatake et al., 1997) y en la de rata (Levine et al., 1997; Jian et al., 2009). Estos datos concuerdan con lo que sucede en la retinogénesis, porque aunque Shh se empieza a sintetizar en el epitelio pigmentario (Stenkamp et al., 2000) también lo expresan las células ganglionares (Neumann y Nüsslein-Volhard, 2000; Amato et al., 2004a; Wang et al., 2005) y las células amacrinas (Shkumatava et al., 2004). Durante el desarrollo la diferenciación de los tipos celulares en la CNI y la CNE, así como la laminación de la retina depende de la actividad de Shh (Shkumatava et al., 2004). Tanto en peces teleósteos (Stenkamp et al., 2000) como en Drosophila, hedgehog controla la diferenciación de los fotorreceptores (Heberlein et al., 1995). Además, en células de mamífero en cultivo, Shh dirige la diferenciación de los progenitores hacia fotorreceptores (Levine et al., 1997; Osakada et al., 2008).

No hemos detectado expresión de Shh en la ZPG del pez cebra adulto (Fig. 4.15), aunque se conoce que Shh promueve la proliferación de los progenitores retinianos localizados en la ZPG de pollos (Moshiri et al., 2005; Wallace, 2008). Como esta proteína se difunde, es posible que en el pez cebra tenga el mismo efecto sobre la ZPG, ya que hemos descrito su presencia en células de la zona de transición adjacente a la ZPG. Sería interesante estudiar la expresión del receptor de Shh, Patched, en las células de la ZPG. Además, cabe resaltar que mediante la técnica de hibridación in situ se localiza el ARNm, con lo que la proteína, aunque se sintetice en las células marcadas, puede realizar su efecto en otras células adyacentes. Se sabe que en la ZPG de Xenopus hay expresión de la proteína transmembrana Smoothened y de los factores de transcripción Gli (Perron et al., 2003). Como dato adicional, es interesante constatar que en la zona subventricular del ratón se expresa la proteína transmembrana Smoothened, mientras que Shh se expresa únicamente en neuronas 
maduras adyacentes (Ihrie et al., 2011). Los efectos de Shh en la laminación de la retina estan mediados por señales célula a célula (Shkumatava et al., 2004), mientras que en la proliferación de progenitores y el desarrollo de células de Müller y fotorreceptores los efectos son dependientes de la concentración de la proteína (Levine et al., 1997; Moshiri et al., 2005).

\section{Colocalizacion de Shh con BrdU}

Según nuestros resultados hay colocalización de Shh y BrdU en las células de la CNI y en la zona de transición adyacente a la ZPG (Fig. 4.16). En la retina de Xenopus hay colocalización de BrdU con elementos de la cascada de Shh (Perron et al., 2003), pero hay muchos ejemplos que indican que Shh es un elemento principal en las células troncales adultas (Fuccillo et al., 2006; Wallace, 2008). La expresión de Shh es importante para la generación inicial y la proliferación de las células neurales adultas de la zona subventricular y el giro dentado (Lai et al., 2003; Han et al., 2008), y la cascada de señalización de Shh tiene una función crítica en la especificación regional de las células troncales del cerebro adulto (Ihrie et al., 2011). Según estos datos es posible que la colocalización que observamos en la retina sea, en parte debida a que las células progenitoras expresen Shh, como sería el caso de la CNI, o debida a la expresión de Shh en algunas células postmitóticas. Tambien, las células positivas para ambos marcadores en la zona de transición podrían ser células postmitóticas, que han incorporado BrdU durante el tratamiento, y que posteriormente expresan Shh que ayudará a la correcta función de las células de la ZPG.

\subsubsection{Nestina}

El filamento intermedio nestina ha sido descrito como un marcador de células troncales y células progenitoras en el SNC de vertebrados (Hockfield y McKay, 1985; Lendahl et al., 1990), aunque varios autores critican este uso, ya que se expresa también en células postmitóticas (Dahlstrand et al., 1995; Gu et al., 2002; Gilyarov, 2008). 
Las funciones concretas de la nestina no se conocen con exactitud, pero se sabe que controla la supervivencia de las células progenitoras neurales mediante la regulación de la apoptosis (Chen et al., 2010), y se postula que interviene en el posicionamiento y funcionamiento de los orgánulos celulares y que sirve como andamiaje de quinasas que regulan diversas funciones celulares como la supervivencia, la proliferación y la diferenciación (Shen et al., 2002; Bieberich et al., 2003; Sahlgren et al., 2003).

\section{Expresión de Nestina en la retina adulta}

La expresión de nestina en la retina es muy variable según las especies. Nuestros resultados indican que la nestina se expresa tanto en células de la CNI y de la CCG como en la ZPG (Fig. 4.19).

En la retina central de humanos se ha descrito la expresión de nestina en la CNI y la CCG (Mayer et al., 2003; Hu et al., 2007; Bhatia et al., 2009), pero no se ha descrito su expresión en la retina de los modelos murinos (Xue et al., 2006; Nickerson et al., 2007). Los trabajos sobre la distribución de la nestina en peces, se reducen a estudios en el carpín (Sánchez-González, 2009), donde la nestina aparece en la CNI y la CCG; en el esturión (Fang et al., 2009), donde hay nestina en los segmentos externos de los fotorreceptores y justo encima de las células horizontales; y en la retinogénesis del pez cebra (Mahler y Driever, 2007), en el que se describe que a los 4 días post-fecundación la expresión de nestina se restringe a la ZPG. En este último trabajo no se estudia la retina adulta, pero se describe en estadios anteriores la expresión de nestina en las células de la CCG. Mediante el estudio de los progenitores adultos del pez cebra, se sabe que la expresión de diferentes marcadores varía entre la etapa embrionaria y la adulta (Wehman et al., 2005; Adolf et al., 2006). Se ha descrito que los elementos positivos a nestina de la CCG son células ganglionares (Mayer et al., 2003; Fischer y Omar, 2005), al igual que durante la retinogénesis del pez cebra (Mahler y Driever, 2007), del pollo (Fischer y Omar, 2005), del ratón (Yang et al., 2000) y de la rata (Lee et al., 2012), aunque no podemos descartar que sean células gliales, ya que se ha descrito la expresión de nestina en astrocitos localizados en la CCG en la retina de la rata (Wan et al., 2008). Actualmente no hay ninguna descripción concreta para las células positivas para nestina de la CNI. Las únicas células de la CNI que se sabe que expresan nestina, 
son las células de Müller (Walcott y Provis, 2003; Fischer y Omar, 2005; Xue et al., 2006). La expresión de nestina en estas células puede ser en situaciones control, o estar inducida por un daño (Luna et al., 2010; Xue et al., 2010), revertiendo las células diferenciadas a indiferenciadas. La nestina se expresa tambien en células de Müller en cultivo (Bhatia et al., 2011; Hollborn et al., 2011). Vista la gran profusión de células marcadas en la CNI en nuestros resultados, no podemos descartar que haya también otros tipos celulares marcados, para lo que habría que realizar dobles marcajes con nestina y con proteínas específicas de cada tipo celular.

Como ya hemos comentado, en este trabajo describimos la presencia de células positivas para nestina en la ZPG. Los resultados son coincidentes con los descritos anteriormente en el carpín (Sánchez-González, 2009), en el pez cebra (Mahler y Driever, 2007) y en el pollo (Fischer y Omar, 2005).

\section{Colocalizacion de Nestina con BrdU}

Según nuestros resultados, las células positivas a nestina que colocalizan con BrdU en la retina central se sitúan en la capa más vitreal de la CNI y en la ZPG (Fig. 4.20), donde se sitúan las células con capacidad proliferativa más indiferenciadas. Esta colocalización se observa también en células progenitoras de carpín (Sánchez-González, 2009). De manera similar, en otros estudios hay colocalización de PCNA y nestina en zonas proliferativas del cerebro del pez cebra (Mahler y Driever, 2007; März et al., 2010), o de BrdU y nestina en la zona periférica de la retina de pollos (Fischer y Omar, 2005). Además, se ha descrito expresión de nestina en células positivas a BrdU en cultivos procedentes del epitelio ciliar de mamíferos (Ahmad et al., 2000; Tropepe et al., 2000; Gu et al., 2007).

Según nuestros resultados, la nestina aparece en progenitores retinianos pero también en otras células de la retina del pez cebra. Se supone que la célula que expresa nestina comienza a cambiar esta proteína de filamento intermedio por otro tipo de proteínas, como vimentina o desmina, en cuanto la célula comienza a diferenciarse (Lendahl et al., 1990; Dahlstrand et al., 1995). La caracterización de las células positivas a nestina que no colocalizan con BrdU necesitará estudios complementarios. Se ha detectado expresión de nestina que colocaliza con marcadores neurales de diferenciación en células progenitoras de la retina de ratón, al menos en 
condiciones de cultivo (Qiu et al., 2007).

\subsection{Cultivo primario de células progenitoras re- tinianas}

A pesar de que se han realizado múltiples estudios sobre la capacidad de división de las células del encéfalo y de la retina adulta de los peces teleósteos (Müller, 1952; Zupanc, 1999; Raymond y Hitchcock, 2000; Ekström et al., 2001; Otteson y Hitchcock, 2003), únicamente disponemos de tres estudios en los que se realiza un cultivo primario de dichas células (Hinsch y Zupanc, 2006; Wen et al., 2008; Servili et al., 2009), además del trabajo inicial llevado a cabo en nuestro laboratorio (Sánchez-González, 2009). En estos trabajos se realiza un cultivo primario de células neurales adultas del pez cuchillo, Apteronotus leptorhynchus, (Hinsch y Zupanc, 2006), de la tilapia Oreochromis sp, (Wen et al., 2008) y de la lubina, Dicentrarchus labrax, (Servili et al., 2009) mediante diferentes procedimientos y distintos medios de cultivo. En el estudio de Wen et al. (2008) las células se cultivan en monocapa, y en los otros dos mediante la obtención de neuroesferas. El único trabajo donde se cultivan las células progenitoras de la retina de un teleósteo es en Sánchez-González (2009), realizado en nuestro laboratorio y cuyos resultados han servido de base para la realización de esta Tesis Doctoral. El reducido número de referencias relativas al cultivo de células progenitoras contrastan con el alto número de estudios de cultivo de células progenitoras de mamíferos, tanto cerebrales -ratón: Reynolds y Weiss (1992); Kukekov et al. (1997); Doetsch et al. (1999); rata: Xu et al. (2003); Xiong et al. (2011); cerdo: Liard et al. (2009); Yang et al. (2012); primates: Oka et al. (2004); humanos: Kukekov et al. (1999); Akiyama et al. (2001)- como retinianos -ratón: Giordano et al. (2007); Xu et al. (2007a); Coles y van der Kooy (2010); De Marzo et al. (2010); rata: Ahmad et al. (1999); Yang et al. (2002); Engelhardt et al. (2004); Monnin et al. (2007); Qiu et al. (2007); Xu et al. (2007a); cerdo: Gu et al. (2007); MacNeil et al. (2007); humanos: Mayer et al. (2005); Xu et al. (2007a); Vossmerbaeumer et al. (2008); Moe et al. (2009); Bhatia et al. (2011)-, lo que sorprende dado el contraste en la capacidad proliferativa y potencialidad de los progenitores neurales y retinianos de teleósteos comparados con los mamíferos. 
La abundante bibliografía existente ha posibilitado realizar trasplantes e implantes de progenitores retinianos. Así, se han realizado trasplantes en animales con distintos tipos de lesión (fotolesión, retinosis pigmentaria, retinas distróficas, retinas control o degeneración de fotorreceptores), distintos tipos de tejido (adulto/embrionario) y distintas procedencias (capa de fotorreceptores, explantes de retina, células progenitoras retinianas, progenitores de bastón, células progenitoras del hipocampo o células troncales). Tan sólo en los últimos dos años se han publicado más de 100 artículos relativos a distintos tipos de trasplantes (revisado en Bull y Martin (2011); Singh y MacLaren (2011); Stern y Temple (2011); Schmeer et al. (2012); Tibbetts et al. (2012)). Un avance relevante ha sido la utilización de células pluripotentes inducidas, dada la facilidad de obtención de dichas células y la ausencia de los problemas éticos derivados de la utilización de células troncales embrionarias (Lamba et al., 2010; Meyer et al., 2011; Okamoto y Takahashi, 2011; Tucker et al., 2011; Zhou et al., 2011). Es también interesante destacar que recientemente se ha publicado un protocolo en el que partiendo de células troncales embrionarias se forma una estructura tridimensional similar a una retina (Eiraku y Sasai, 2011; Nakano et al., 2012).

Nuestros resultados demuestran, por primera vez, que el protocolo desarrollado en este trabajo es útil para cultivar los progenitores retinianos del pez cebra adulto. Para su realización la concentración inicial de células utilizada es de 200.000 células por $8 \mathrm{~mL}$ (25000 células $/ \mathrm{mL}$ ) de medio de cultivo (Fig. 4.23). Esta densidad es muy inferior a la utilizada para otros cultivos, como los del cerebro del pez cuchillo (Hinsch y Zupanc, 2006), donde la concentración inicial es de $2 \times 10^{6}$ células $/ \mathrm{mL}$. En cambio, en otros estudios utilizan una densidad celular similar (Stafford et al., 2007; Xu et al., 2007a; Liard et al., 2009; McLenachan et al., 2009).

Desde 1989 se sabe que una lesión del nervio óptico produce un aumento de las células que se dividen en la retina (Henken y Yoon, 1989; Bähr, 1991; OwusuYaw et al., 1992; Panagis et al., 2005; Wohl et al., 2009), aunque no hay ninguna información sobre el efecto en el pez cebra anterior a nuestros resultados (Fig. 4.24). Tampoco hay estudios sobre el efecto del pinzamiento del nervio óptico en cultivos de células retinianas, excepto un estudio sobre explantes de retina (Bähr, 1991). En nuestro caso los resultados no han sido los inicialmente previstos, ya que el pinzamiento del nervio óptico no tiene prácticamente ningún efecto en el número de neuroesferas obtenidas a los 7 días en cultivo (Fig. 4.25). Como se ha comentado en 
la sección de resultados, es posible que ello se deba a una inadecuada elección del periodo entre la lesión y el cultivo, aunque otra posibilidad es que gran parte de las células en división que se observan en las secciones sean células gliales, que no son capaces de proliferar en el medio Neurobasal A utilizado (Brewer et al., 1993).

En el trabajo de Sánchez-González (2009) se realiza una disgregación de las neuroesferas cada 2-3 días, mediante un procedimiento mecánico. Para suavizar este tratamiento, y dada la importancia que tiene el tamaño de las neuroesferas para que el pase sea efectivo (Xiong et al., 2011), hemos preferido realizar un cambio de medio a los 7 días, disgregando las neuroesferas con Accutase ${ }^{\circledR}$, una mezcla enzimática más suave que la tripsina (Wachs et al., 2003; Zheng et al., 2006; Monnin et al., 2007). Además, al realizar el cambio de cultivo, se cambia la mitad del medio, añadiéndo los factores de crecimiento cada dos días. Esta modificación, junto con la adaptación de la concentración de antibióticos (Fig. 4.22), nos ha permitido obtener un mayor número de neuroesferas en un tiempo menor.

A lo largo de las primeras dos semanas se observa un aumento del tamaño de las neuroesferas, tanto si consideramos la primera apreciación visual (Fig. 4.26) como si medimos el área de las mismas (Fig. 4.27). Las neuroesferas obtenidas a partir de progenitores del carpín (Sánchez-González, 2009) tienen una tasa de crecimiento similar. También las neuroesferas obtenidas a partir del cerebro del pez cuchillo (Hinsch y Zupanc, 2006) tienen un crecimiento y un tamaño similar al que obtenemos al medir el área en nuestro trabajo. Si lo comparamos con los resultados obtenidos a partir de retinas de ratón, rata o humano (Xu et al., 2007a), las neuroesferas obtenidas en este trabajo son de menor tamaño. Según nuestros resultados, las neuroesferas a los 7 días in vitro miden $732 \mu \mathrm{m}^{2}$, mientras que las obtenidas a partir de células del epitelio ciliar de rata, ratón o humano son de aproximadamente 15175 $\mu m^{2}$ (Xu et al., 2007a).

El ensayo de MTT es utilizado principalmente para estudiar la toxicidad de distintas moléculas (Kaneko et al., 2007; Boeckel et al., 2012), aunque también se utiliza para comprobar la viabilidad del cultivo, lo que está en relación directa con la proliferación de las células (Roisen et al., 2001; Hinsch y Zupanc, 2006; Zheng et al., 2007; McLenachan et al., 2009; Xiong et al., 2011). Nuestros resultados confirman un aumento de la proliferación a lo largo de las dos primeras semanas de cultivo (Fig. 4.28). Como ya se ha comentado en la sección de resultados, la dilución de las 
células en el doble de medio al realizar el pase, explicaría que la diferencia entre los 7 y los 14 días en cultivo sea menor que entre 1 y 7 días.

\subsection{Caracterización de las neuroesferas}

Cuando se trata de caracterizar las neuroesferas en cultivo, el primer paso es adherir las esferas a cubreobjetos a fin de poder realizar el protocolo de inmunocitoquímica. El procedimiento más comunmente utilizado es el tratamiento de la superficie donde se van a sembrar las células con poliaminoácidos (poliornitina o polilisina) o con proteínas de la matriz extracelular (laminina o fibronectina) (revisado en Sun et al. (2012)). Todos estos métodos requieren de una incubación a $37,5^{\circ} \mathrm{C}$, temperatura inadecuada para el cultivo de progenitores retinianos de animales poiquilotermos con nicho de $28,5^{\circ} \mathrm{C}$. Por ello, preferimos utilizar el Matrigel ${ }^{\circledR}$, un gel derivado de proteínas del sarcoma del ratón, utilizado para fijar esferas al sustrato (Katakowski et al., 2005; Braun et al., 2006; Durbec et al., 2008; González-Curto, 2010; Koutsopoulos y Zhang, 2013). La concentración de Matrigel que originó los mejores resultados fue la de 1:50 (Fig. 4.29). La concentración a la que se utiliza en otros casos varía desde poner Matrigel ${ }^{\circledR}$ puro, hasta diluciones de 1:100 (Katakowski et al., 2005; Braun et al., 2006; Durbec et al., 2008; González-Curto, 2010; Koutsopoulos y Zhang, 2013).

\subsubsection{Incorporación de BrdU}

La BrdU es un análogo de la timidina que se integra en la fase $\mathrm{S}$ de las células en division, y en consecuencia es utilizado para marcar células progenitoras. Al igual que se utiliza en ensayos ex vivo, como los realizados mediante inyección intraperitoneal en este trabajo, se utiliza también para estudios in vitro. En esta Tesis Doctoral hemos incubado las neuroesferas con BrdU durante dos horas a una concentración final de 5 $\mathrm{M}$. Esta incubación, modificada de González-Curto (2010), ha permitido observar que tanto a los 7 días como a los 14 días in vitro hay células que se dividen durante las dos horas de incubación con BrdU (Fig. 4.30). Son necesarios estudios futuros de determinación del porcentaje de células marcadas. Es importante destacar que este marcador se ha utilizado en otros estudios en distintas 
concentraciones y distintos tiempos de incubación, lo que puede variar los resultados obtenidos (Cuadro 5.1).

\begin{tabular}{|c|c|c|c|}
\hline Referencia & Concentración BrdU & Tiempo de incubación & Especie \\
\hline Shetty y Turner (1998) & $1 \mu \mathrm{M}$ & 7 horas & ratón \\
\hline Ahmad et al. (1999) & $10 \mu \mathrm{M}$ & Una noche & rata \\
\hline Yang et al. (2002) & $10 \mu \mathrm{M}$ & Una noche $/ 5$ días & rata \\
\hline Wachs et al. (2003) & $1 \mu \mathrm{M}$ & 48 horas & rata \\
\hline Mayer et al. (2005) & $10 \mu \mathrm{M}$ & 1 semana & humano \\
\hline Zheng et al. (2006) & $30 \mu \mathrm{g} / \mathrm{mL}$ & 24 horas & ratón \\
\hline MacNeil et al. $(2007)$ & $0,5 \mu \mathrm{M}$ & 4 horas & cerdo \\
\hline Zheng et al. $(2007)$ & $30 \mu \mathrm{g} / \mathrm{mL}$ & 40 minutos & rata \\
\hline González-Curto $(2010)$ & $5 \mu \mathrm{M}$ & 1 hora & ratón \\
\hline Merlo et al. $(2011)$ & $1 \mu \mathrm{M}$ & 24 horas & ratón \\
\hline
\end{tabular}

Cuadro 5.1: Concentraciones y tiempos de incubación de BrdU utilizados en otros estudios

Aunque la BrdU ha sido utilizada para marcar proliferación, hay que tener en cuenta también que tiene diversos efectos sobre las células progenitoras neurales. Aunque tiene baja toxicidad (Taupin, 2007), a dosis superiores a $0,2 \mu \mathrm{M}$ puede afectar a la supervivencia de progenitores neuronales pero no de progenitores gliales (Caldwell et al., 2005; Lehner et al., 2011). Asímismo, la BrdU altera la metilación del ADN e induce la diferenciación hacia células gliales, principalmente astrocitos (Schneider y d'Adda di Fagagna, 2012), interfiriendo con la capacidad proliferativa de las células progenitoras (Ross et al., 2008; Lehner et al., 2011). Por ésto sería necesario utilizar otra forma de marcar las células en división, sobre todo para futuros estudios de diferenciación. En esta Tesis Doctoral no hemos realizado dobles marcajes con BrdU y otros marcadores para asegurarnos de que el marcaje no se veía influido por la incubacion con BrdU.

\subsubsection{Prox 1}

Para comprobar si además de en secciones, Prox1 se expresa también en neuroesferas en cultivo, realizamos una técnica inmunocitoquímica sobre las neuroesferas. Así pudimos comprobar que Prox1 se expresa tanto a los 7 como a los 14 días en cultivo (Fig. 4.31), siendo más abundante su expresión a los 14 días. No se han encontrado estudios precedentes donde se describa la expresión de Prox1 en cultivo 
de neuroesferas, excepto tras la inducción de la diferenciación (Lavado et al., 2010) o en células trasplantadas (Chen et al., 2011). Como ya se ha comentado anteriormente, Prox1 es un factor de transcripción implicado en la diferenciación, por lo que es lógico que el mayor número de células marcadas se obtenga a los 14 días, ya que de manera espontánea, algunas células de las neuroesferas pueden comenzar a diferenciarse.

A los 14 días encontramos expresión de Prox1 tanto en el citoplasma como en el núcleo, y en ensayos de Western Blot se obtiene una única banda (Fig. $4.32 \mathrm{~A}$ ). Este dato nos hace descartar que Prox1 sufra una sumoilización, ya que dicha modificación post-traduccional se asocia a una variación en el peso de la proteína. La sumoilización de Prox1 se da en células en cultivo, probablemente con el fin de regular la actividad corepresora de la proteína (Shan et al., 2008). El gen Prox1 es homólogo al gen Prospero de Drosophila, que contiene una región de localización nuclear, y una región denominada dominio prospero que actúa como una señal de exportación nuclear, y se regula mediante la actividad de la exportina y la proteína Miranda (que la retiene en el citoplasma) (Demidenko et al., 2001). Prospero se expresa en el citoplasma de células indiferenciadas con capacidad proliferativa, mientras que la expresión nuclear se da en células postmitóticas en diferenciación (Manning y Doe, 1999; Li et al., 2000). De manera similar, Prox1 se expresa tanto en el citoplasma como en el núcleo a lo largo del desarrollo del cristalino en ratones, ratas y pollos (Duncan et al., 2002). Con todos estos datos los resultados del marcaje con Prox1 en las neuroesferas, indican la presencia de células en proceso de diferenciación, que expresan Prox1 en el núcleo, y otras células que expresan Prox1 en el citoplasma y mantienen la capacidad de división. Dentro de una neuroesfera no todas las células expresan Prox1, con lo cual es posible que aquellas células que tienen Prox1 en el citoplasma, estén, en cierto modo, predeterminadas a diferenciarse hacia algún tipo celular concreto. Para comprobar esta hipótesis serían necesarios estudios de colocalización de Prox1 con marcadores específicos de los distintos tipos celulares de la retina.

\subsubsection{Pax6}

Las neuroesferas formadas a partir de progenitores retinianos expresan Pax6 tanto a los 7 como a los 14 días (Fig. 4.33). Teniendo en cuenta la función de Pax6, podemos decir que las células de las neuroesferas marcadas son células con 
capacidad de proliferación. Este es un marcador utilizado para identificar células indiferenciadas en las neuroesferas derivadas de cultivos de cerebro (Kukekov et al., 1999; Hack et al., 2004; Duparc et al., 2007; von Holst et al., 2007; Remboutsika et al., 2011; Schneider y d'Adda di Fagagna, 2012) y de cultivos de progenitores retinianos (Lawrence et al., 2007; MacNeil et al., 2007; Qiu et al., 2007; Xu et al., 2007b).

La expresión de Pax6 es tanto citoplasmática como nuclear, y en el Western Blot obtenemos dos bandas, una de alrededor de $48 \mathrm{kDa}$ y otra de unos $33 \mathrm{kDa}$ (Fig. 4.32 B). Pax6 es una proteína que tiene varias isoformas. Se descubrió por primera vez en la codorniz, donde hay 5 isoformas caracterizadas por los diferentes pesos moleculares (32, 33, 43, 46 y $48 \mathrm{kDa}$ ) (Carrière et al., 1993). Se sabe que Pax6 tiene tres promotores y seis potenciadores o enhancers (Ferreiro-Galve et al., 2012), y dentro de su estructura hay dos señales de localización nuclear, una en el dominio "paired" y la otra en el homeodominio (Carrière et al., 1995). De todas las isoformas, las que pesan 32 y 33 se encuentran en el citoplasma, y el resto en el núcleo (Carrière et al., 1995). En el pez cebra el gen Pax6a tiene dos isoformas, una con el dominio "paired" y otra sin él, siendo esta última la que se localiza en el citoplasma (Lakowski et al., 2007). Nuestros resultados de Western Blot (Fig. 4.32 B) muestran dos bandas con estos pesos moleculares de $33 \mathrm{kDa}$ (correspondiente a la proteína sin el dominio "paired" situada en el citoplasma) y de $48 \mathrm{kDa}$ (correspondiente a la isoforma nuclear con el dominio "paired"). Además estas isoformas de Pax6 pueden sufrir modificaciones como pueden ser la sumoilización temporal (Yan et al., 2010) o la desfosforilación por la proteína fosfatasa 1 que inhibe su actividad (Yan et al., 2007). No podemos descartar que estas modificaciones se produzcan en las células positivas a Pax6 en las neuroesferas en cultivo.

\subsubsection{Sox 2}

Sox2 es un marcador de células proliferativas utilizado para localizar las células indiferenciadas en neuroesferas de diferentes organismos como lubina (Servili et al., 2009), ratón (Miyagi et al., 2006; Favaro et al., 2009; Remboutsika et al., 2011), rata (Yan et al., 2012), cerdo (MacNeil et al., 2007; Liard et al., 2009; Yang et al., 2012), perro (Lim et al., 2012), mono (Homman-Ludiye et al., 2012) o humano (Moe et al., 2009). Junto con la nestina es el marcador más utilizado para detectar células 
troncales. En nuestro caso, dado que no hay un anticuerpo para nestina eficiente en nuestro modelo, y que no es posible realizar la técnica de hibridación in situ sobre los cubreobjetos utilizados para fijar las neuroesferas, hemos decidido utilizar este marcador. Sox2 se expresa en algunas células de las neuroesferas tanto a los 7 como a los 14 días (Fig. 4.34).

Dado que la expresión a los 14 días en cultivo se produce en el citoplasma y en el núcleo realizamos la técnica de Western Blot, obteniendo dos bandas, una de alrededor de $34 \mathrm{kDa}$ y la otra de $55 \mathrm{kDa}$ (Fig. $4.32 \mathrm{C}$ ). La expresión de Sox2 en el citoplasma es un hecho descrito anteriormente: en las células del cristalino (Kamachi et al., 1998; Hever et al., 2006), y en las células de Müller de la retina humana, donde Sox2 se expresa tanto en el citoplasma como en el núcleo (Bhatia et al., 2009). Durante la embriogénesis temprana Sox2 se transloca entre el citoplasma y el núcleo sugiriendo que la actividad de dicho factor de transcripción está sujeta a la localización subcelular (Avilion et al., 2003). La señal de localización nuclear se encuentra en el dominio HMG (grupo de alta movilidad, en sus siglas en inglés) (Poulat et al., 1995). En nuestro caso, dados los pesos moleculares, podemos decir que la proteína con un peso de $55 \mathrm{kDa}$ se encuentra sumoilizada, como ya se ha descrito en distintas líneas celulares (Tsuruzoe et al., 2006). Hay que tener en consideración, que la forma sumoilizada, localizada en el citoplasma es una forma inactiva (Tsuruzoe et al., 2006), por lo que las células marcadas así pueden ser células en proceso de diferenciación.

Tal y como se ha descrito anteriormente, dada la relación entre los tres marcadores aquí descritos (Prox1, Pax6 y Sox2) (Fig. 5.1), es posible que haya colocalización de las tres proteínas en las mismas células. La combinación de los marcadores, así como el marcaje con otras proteínas implicadas o en la regulación del mantenimiento de la potencialidad o en la diferenciación, completará la caracterización de las células progenitoras retinanas en cultivo.

\subsection{Diferenciación de las neuroesferas en cultivo}

Para completar los estudios de caracterización de las neuroesferas en cultivo, hemos comenzado a desarrollar los estudios de diferenciación de las neuroesferas. Las 
neuroesferas, después de haber crecido durante una semana en condiciones normalizadas, se transfieren a un medio sin factores de crecimiento durante otros 7 días. Para comprobar cómo se comportaban las neuroesferas en ausencia de los factores de crecimiento, hemos realizado una doble inmunocitoquímica con Sox2 como marcador de células indiferenciadas y calretinina (CR) como marcador de diferenciación. Tanto CR como Sox2 son dos marcadores comúnmente utilizados para distinguir las células que se han diferenciado de las que siguen en un estadio indiferenciado (Yang et al., 2002; Fischer et al., 2004; Lawrence et al., 2007; Martínez-Monedero et al., 2008; Monzo et al., 2012).

En las neuroesferas a las que no se les ha añadido factores de crecimiento hay células que expresan CR, además de células que expresan Sox2 (Fig. $4.35 \mathrm{~A}$ ), sin colocalizar en ninguno de los casos. La expresión de Sox2 se detecta también en neuroesferas en la situación de control, pero en ningún caso hemos visto expresión de CR en estos cultivos (Fig. 4.35 B). Ni en las neuroesferas control ni en las diferenciadas, hemos detectado expresión de Sox2 en el citoplasma. La calretinina se expresa tan solo en unas pocas células de cada neuroesfera diferenciada. Es posible que el reducido número de células se deba a que el tiempo que están en el medio sin factores de crecimiento no sea suficiente para diferenciar las células, o puede que, además de los factores de crecimiento, haya que retirar del cultivo el suplemento B27, ya que este suplemento aumenta la proliferación celular (Svendsen et al., 1995; Wachs et al., 2003).

La retirada de los factores de crecimiento es uno de los primeros ensayos que se realizan para estudiar la diferenciación de las neuroesferas (Chiang et al., 1996; Duittoz y Hevor, 2001; Yang et al., 2002; Jori et al., 2003; Singh et al., 2009; Yang et al., 2012). Los factores FGF y EGF, junto con otros como el PDGF (factor de crecimiento derivado de plaquetas) o el CNTF (factor neurotrófico ciliar), inducen la división e inhiben la diferenciación de las células (Bögler et al., 1990; Kuhn et al., 1997; Raballo et al., 2000; Caldwell et al., 2001; Shi et al., 2008). Se encuentran tanto durante el desarrollo (Birecree et al., 1991; Tucker et al., 1993; Kalyani et al., 1999; Gómez et al., 2004; Laisney et al., 2010), como en el cerebro adulto (PlataSalamán, 1991; Tucker et al., 1993; Seroogy et al., 1995; Kalyani et al., 1999; Gómez et al., 2004; Laisney et al., 2010). Realizan su actividad uniéndose a sus receptores, así la unión de EGF a su receptor activa las cascadas de señalización de las quinasas MAPK, Akt y JNK, que activan factores de transcripción que controlan la 
proliferación celular e inhiben la apoptosis (Herbst, 2004; Oda et al., 2005); FGF tiene una familia de receptores, que tienen distintas funciones (Coutts y Gallagher, 1995; Ornitz et al., 1996). En este sentido se ha descrito que aunque el FGF es un factor mitogénico (Haynes, 1988; Stachowiak et al., 1997; Sütterlin et al., 2013), si se añade únicamente FGF a un medio sin ningún otro factor, en cultivos de retina de rata (Hicks y Courtois, 1992), de células de la retina de humanos (Carwile et al., 1998) y de células embrionarias de ratón, mono y humano (Osakada et al., 2008), se puede producir la diferenciación de las células hacia fotorreceptores .

Además de la retirada de los factores de crecimiento, se han realizado diversos ensayos añadiendo distintas moléculas para dirigir la diferenciación celular. Entre ellas, además del FGF ya mencionado, se ha testado el suero fetal bobino (Yang et al., 2002; Liu et al., 2005; MacNeil et al., 2007; Kokkinopoulos et al., 2008), el ácido retinóico (Stenkamp et al., 1993; Kelley et al., 1999; Lawrence et al., 2007; Martínez-Monedero et al., 2008; Osakada et al., 2008; Safari et al., 2009; Wu et al., 2012), la proteína Shh (Martínez-Monedero et al., 2008; Zeng et al., 2007; Osakada et al., 2008; Osterberg y Roussa, 2009; Wu et al., 2012) o un medio condicionado derivado del epitelio pigmentario (Gaur et al., 1992; Kholodenko et al., 2006; Sheedlo et al., 2007; Gamm et al., 2008).

Los resultados obtenidos en esta Tesis Doctoral en relación con la diferenciación de los progenitores neurales de retina adulta del pez cebra sugieren nuevos ensayos que incluyan la adición de determinadas moléculas al cultivo, y el marcaje con distintas proteínas específicas de cada uno de los tipos celulares de la retina. 
Capítulo 6

Conclusiones 
6. Conclusiones 
Las conclusiones de la presente Tesis Doctoral son:

1. El protocolo de inyección intraperitoneal de BrdU desarrollado en este trabajo permite marcar las distintas poblaciones de progenitores en la retina adulta del pez cebra, tanto en la zona periférica germinal como en la retina central, y en ésta, tanto en la capa nuclear interna como en la capa nuclear externa.

2. Una única inyección de BrdU permite detectar las primeras células marcadas a los 30 minutos, la señal se mantiene, al menos, hasta los 28 días y la mayor tasa de proliferación se detecta 1 día después de la inyección.

3. Los progenitores neurales, tanto en la ZPG como en la retina central, expresan marcadores acordes con su estadio de diferenciación (Prox1, Pax6, Sox2, Islet1, Shh, Nestina).

4. El protocolo desarrollado en esta Tesis Doctoral permite cultivar las células progenitoras de la retina del pez cebra, manteniendo tanto la viabilidad como la capacidad proliferativa y de diferenciación de las mismas.

5. Las neuroesferas derivadas de las células progenitoras de la retina adulta contienen células que expresan Prox1, Pax6 y/o Sox2, en el citoplasma o en el núcleo, por lo que estas neuroesferas contienen células en distintas fases del ciclo celular y en diferentes estadios de diferenciación.

6. La supresión de los factores de crecimiento del cultivo de neuroesferas induce la diferenciación de algunas células, asociada a la expresión de calretinina, al tiempo que otras células de la misma neuroesfera se mantienen indiferenciadas y expresan Sox2. 
6. Conclusiones 
Capítulo 7

\section{Bibliografía}


7. Bibliografía 


\section{Bibliografía}

Adolf, B., Chapouton, P., Lam, C. S., Topp, S., Tannhäuser, B., Strähle, U., Götz, M. y BallyCuif, L. (2006). Conserved and acquired features of adult neurogenesis in the zebrafish telencephalon. Dev Biol 295, 278-293.

Agathocleous, M., Iordanova, I., Willardsen, M. I., Xue, X. Y., Vetter, M. L., Harris, W. A. y Moore, K. B. (2009). A directional Wnt/ $\beta$ catenin/Sox2-proneural pathway regulates the transition form proliferation to differentiation in the $\mathrm{Xe}$ nopus retina. Development 136, 3289-3299.

Agatholeous, M. y Harris, W. A. (2009). From progenitors to differentiated cells in the vertebrate retina. Annu Rev Cell Dev Biol 25, 45-69.

Ahmad, I., Dooley, C. M., Thoreson, W. B., Rogers, J. A. y Afiat, S. (1999). In vitro analysis of a mammalian retinal progenitor that gives rise to neurons and glia. Brain Res 831, 1-10.

Ahmad, I., Tang, L. y Pham, H. (2000). Identification of neural progenitors in the adult mammalian eye. Biochem Biophys Res Commun 270, 517-521.

Ahnelt, P., Keri, C. y Kolb, H. (1990). Identification of pedicles of putative blue-sensitive cones in the human retina. J Comp Neurol 293:1, 39-53.

Akiyama, Y., Honmou, O., Kato, T., Uede, T., Hashi, K. y Kocsis, J. D. (2001). Transplantation of clonal neural precursor cells derived from adult human brain establishes functional peripheral myelin in the rat spinal cord. Exp Neurol 167, 27-39.

Altman, J. (1962). Are new neurons formed in the brains of adult mammals? Science 135, 1127-1128.

Altmann, C. R., Chow, R. L., Lang, R. A. y Hemmati-Brivanlou, A. (1997). Lens induction by Pax-6 in Xenopus laevis. Dev Biol 185, 119-123.

Alunni, A., Menuet, A., Candal, E., Pénigault, J. B., Jeffery, W. R. y Rétaux, S. (2007). Developmental mechanisms for retinal degeneration in the blind cavefish Astyanax mexicanus. J Comp Neurol $\mathbf{5 0 5}, 221-233$.

Alvarez-Buylla, A. y García-Verdugo, J. M. (2002). Neurogenesis in adult subventricular zone. $J$ Neurosci 22, 629-634.
Amato, M. A., Boy, S. y Perron, M. (2004a). Hedgehog signaling in vertebrate eye development: a growing puzzle. Cell Mol Life Sci 61, 899-910.

Amato, M. A., Arnault, E. y Perron, M. (2004b). Retinal stem cells in vertebrates: parallels and divergences. Int J Dev Biol 48, 993-1001.

Amirpour, N., Karamali, F., Rabiee, F., Rezaei, L., Esfandiari, E., Razavi, S., Dehghani, A., Razmju, H., Nasr-Esfahani, M. H. y Baharvand, H. (2012). Differentiation of human embryonic stem cell-derived retinal progenitors into retinal cells by sonic hedgehog and/or retinal pigmented epithelium and transplantation into the subretinal space of sodium iodate-injected rabbits. Stem Cells Dev $\mathbf{2 1}$, $42-53$.

Appel, B., Korzh, V., Glasgow, E., Thor, S., Edlund, T., Dawid, I. B. y Eisen, J. S. (1995). Motoneuron fate specification revealed by patterned LIM homeobox gene expression in embryonic zebrafish. Development 121, 4117-4125.

Arden, G. B., Sidman, R. L., Arap, W. y Schlingemann, R. O. (2005). Spare the rod and spoil the eye. Br J Ophthalmol 89, 764-769.

Arenzana, F. J., Santos-Ledo, A., Porteros, A., Aijón, J., Velasco, A., Lara, J. M. y Arévalo, R. (2011). Characterisation of neuronal and glial populations of the visual system during zebrafish lifespan. Int J Dev Neurosci 29, 441-449.

Arévalo, R., Alonso, J. R., Porteros, A., Briñón, J. G., Crespo, C., Lara, J. y Aijón, J. (1995). Calretinin-like immunoreactivity in the optic tectum of the tench (Tinca tinca L). Brain Res 671, 112-118.

Austin, C. P., Feldman, D. E., Ida, J. A. J. y Cepko, C. L. (1995). Vertebrate retinal ganglion cells are selected from competent progenitors by the action of Notch. Development 121, 3637-3650.

Avilion, A. A., Nicolis, S. K., Pevny, L. H., Perez, L., Vivian, N. y Lovell-Badge, R. (2003). Multipotent cell lineages in early mouse development depend on SOX2 function. Genes Dev 17, 126-140.

Bähr, M. (1991). Adult rat retinal glia in vitro: effects of in vivo crush-activation on glia proliferation and permissiveness for regenerating retinal ganglion cell axons. Exp Neurol 111, 65-73. 
Barthel, L. K. y Raymond, P. A. (1993). Subcellular localization of alpha-tubulin and opsin mRNA in the goldfish retina using digoxigenin-labeled cRNA probes detected by alkaline phosphatase and HRP histochemistry. J Neurosci Methods 50, 145-152.

Bäumer, N., Marquardt, T., Stoykova, A., Spieler, D., Treichel, D., Ashery-Padan, R. y Gruss, P. (2003). Retinal pigmented epithelium determination requires the redundant activities of Pax2 and Pax6. Development 130, 2903-2915.

Beaudet, L., Novales, F. I. y Hawryshyn, C. W (1997). Cone photoreceptor topography in the retina of sexually mature pacific salmonid fishes. J Comp Neurol 338, 49-59.

Bejarano-Escobar, R., Blasco, M., DeGrip, W. J. Martín-Partido, G. y Francisco-Morcillo, J. (2009). Cell differentiation in the retina of an epibenthonic teleost, the Tench (Tinca tinca, Linneo 1758). Exp Eye Res 89, 398-415.

Belecky-Adams, T., Tomarev, S., Li, H. S., Ploder, L., McInnes, R. R., Sundin, O. y Adler, R. (1997). Pax-6, Prox 1, and Chx10 homeobox gene expression correlates with phenotypic fate of retinal precursor cells. Invest Ophthalmol Vis Sci 38, 12931303.

Bernardos, R. L., Barthel, L. K., Meyers, J. R. y Raymond, P. A. (2007). Late-stage neuronal progenitors in the retina are radial Müller glia that function as retinal stem cells. J Neurosci 27, 7028-7040.

Bernocchi, G., Scherini, E., Giacometti, S. y Mares, V. (1990). Premitotic DNA synthesis in the brain of the adult frog (Rana esculenta L.): an autoradiographic 3H-thymidine study. Anat Rec 228, 461-470.

Bhat, S. P., Rayner, S. A., Huang, C. M. y Ariyasu, R. G. (1999). Quantitative estimation of RNA transcripts suggests persistence of pax-6 expression in the postembryonic chick retina. Dev Neurosci 21, $140-146$.

Bhatia, B., Singhal, S., Lawrence, J. M., Khaw, P. T. y Limb, G. A. (2009). Distribution of Müller stem cells within the neural retina: evidence for the existence of a ciliary margin-like zone in the adult human eye. Exp Eye Res 89, 373-382.

Bhatia, B., Jayaram, H., Singhal, S., Jones, M. F. y Limb, G. A. (2011). Differences between the neurogenic and proliferative abilities of Müller glia with stem cell characteristics and the ciliary epithelium from the adult human eye. Exp Eye Res 93, 852861.

Bick, M. D. y Davidson, R. L. (1974). Total substitution of bromodeoxyuridine for thymidine in the DNA of a bromodeoxyuridine-dependent cell line. Proc Natl Acad Sci USA 71, 2082-2086.
Bieberich, E., MacKinnon, S., Silva, J., Noggle, S. y Condie, B. G. (2003). Regulation of cell death in mitotic neural progenitor cells by asymmetric distribution of prostate apoptosis response 4 (PAR-4) and simultaneous elevation of endogenous ceramide. J Cell Biol 162, 469-479.

Birecree, E., King, L. E. y Nanney, L. B. (1991). Epidermal growth factor and its receptor in the developing human nervous system. Brain Res Dev Brain Res 60, 145-154.

Boeckel, D. G., Shinkai, R. S., Grossi, M. L. y Teixeira, E. R. (2012). In vitro evaluation of cytotoxicity of hyaluronic acid as an extracellular matrix on OFCOL II cells by the MTT assay. Oral Surg Oral Med Oral Pathol Oral Radiol 4403:12.

Bögler, O., Wren, D., Barnett, S. C., Land, H. y Noble, M. (1990). Cooperation between two growth factors promotes extended self-renewal and inhibits differentiation of oligodendrocyte-type- 2 astrocyte (O-2A) progenitor cells. Proc Natl Acad Sci USA 87, 6368-6372.

Boije, H., Edqvist, P. H. y Hallböök, F. (2008). Temporal and spatial expression of transcription factors FoxN4, Ptfla, Prox1, Isl1 and Lim1 mRNA in the developing chick retina. Gene Expr Patterns 8, $117-123$.

Boije, H., Ring, H., López-Gallardo, M., Prada, C. y Hallböök, F. (2010). Pax2 is expressed in a subpopulation of Müller cells in the central chick retina. Dev Dyn 239, 1858-1866.

Bolton, W. E., Mikulka, W. R., Healy, C. G., Schmittling, R. J. y Kenyon, N. S. (1992). Expression of proliferation associated antigens in the cell cycle of synchronized mammalian cells. Cytometry 13, 117-126.

Böswald, M., Harasim, S. y Maurer-Schultze, B. (1990). Tracer dose and availability time of thymidine and bromodeoxyuridine: application of bromodeoxyuridine in cell kinetic studies. Cell tissue kinet 23, 169-181.

Boucher, S. E. y Hitchcock, P. F. (1998). Insulinrelated growth factors stimulate proliferation of retinal progenitors in the goldfish. J Comp Neurol $\mathbf{3 9 4}$, 386-394.

Bowles, J., Schepers, G. y Koopman, P. (2000). Phylogeny of the SOX family of developmental transcription factors based on sequence and structural indicators. Dev Biol 227, 239-255.

Boycott, B. B. y Wäsle, H. (1974). The morphological types of ganglion cells of the domestic cat's retina. J Physiol 240, 397-419.

Branchek, T. y Bremiller, R. (1984). The development of photoreceptors in the zebrafish Brachidanio rerio I. Structure. J Comp Neurol 224, 107-115. 
Brandt, M. D., Jessberger, S., Steiner, B., Kronenberg, G., Reuter, K., Bick-Sander, A., von der Behrens, W. y Kempermann, G. (2003). Transient calretinin expression defines early postmitotic step of neuronal differentiation in adult hippocampal neurogenesis of mice. Mol Cell Neurosci 24, 603-613.

Braun, H., Bühnemann, C., Neumann, J. y Reymann, K. G. (2006). Preparation of a tissue-like cortical primary culture from embryonic rats using Matrigel and serum free Start V Medium. J Neurosci Methods 157, 32-38.

Bravo, R., Frank, R., Blundell, P. A. y Macdonald-Bravo, H. (1987). Cyclin/PCNA is the auxiliary protein of DNA polymerase-delta. Nature 326, $515-517$.

Bravo, R. y Macdonald-Bravo, H. (1987). Existence of two populations of cyclin/proliferating cell nuclear antigen during the cell cycle: association with DNA replication sites. J Cell Biol 105, 1549-1554.

Brewer, G. J., Torricelli, J. R., Evege, E. K. y Price, P. J. (1993). Optimized survival of hippocampal neurons in B27-supplemented Neurobasal, a new serum-free medium combination. $J$ Neurosci Res 35, 567-576.

Bringmann, A., Skatchkov, S. N., Pannicke, T., Biedermann, B., Wolburg, H., Orky, R. K. y Reichenbach, A. (2000). Müller glial cells in anuran retina. Microsc Res Tech 50, 384-393.

Briscoe, J., Pierani, A., Jessell, T. M. y Ericson, J. (2000). A homeodomain protein code specifies progenitor cell identity and neuronal fate in the ventral neural tube. Cell 101, 435-445.

Bu, L., Jiang, X., Martin-Puig, S., Caron, L., Zhu, S., Shao, Y., Roberts, D. J., Huang, P. L., Domian, I. J. y Chien, K. R. (2009). Human ISL1 heart progenitors generate diverse multipotent cardiovascular cell lineages. Nature 460, 113-117.

Bull, N. D. y Martin, K. R. (2011). Concise review: toward stem cell-based therapies for retinal neurodegenerative diseases. Stem Cells 29, 1170-1175.

Bürglin, T. R. (1994). A Caenorhabditis elegans prospero homologue defines a novel domain. Trends Biochem Sci 19, 70-71.

Burnside, B., Wang, E., Pagh-Roehl, K. y Rey, H. (1993). Retinomotor movements in isolated teleost retinal cone inner-outer segment preparations (cis-cos): effects of light, dark and dopamine. Exp Eye Res 57, 709-722.

Burril, J. D. y Easter, S. J. (1994). Development of the retinofugal projections in the embryonic and larval zebrafish (Brachydanio rerio). J Comp Neurol 346, 583-600.
Bussow, H. (1980). The astrocytes in the retina and optic nerve head of mammals: a special glia for the ganglion cell axons. Cell Tissue Res 206, 367-378.

Bylund, M., Andersson, E., Novitch, B. G. y Muhr, J. (2003). Vertebrate neurogenesis is counteracted by Sox1-3 activity. Nat Neurosci 6, 1162-1168.

Caldwell, M. A., He, X., Wilkie, N., Pollack, S., Marshall, G., Wafford, K. A. y Svendsen, C. N. (2001). Growth factors regulate the survival and fate of cells derived from human neurospheres. Nat Biotechnol 19, 475-479.

Caldwell, M. A., He, X. y Svendsen, C. N. (2005). 5-Bromo-2'-deoxyuridine is selectively toxic to neuronal precursors in vitro. Eur J Neurosci 22, 29652970.

Callaerts, P., Halder, G. y Gehring, W. J. (1997). Pax-6 in development and evolution. Annu Rev Neurosci $20,483-532$.

Calof, A. L., Bonnin, A., Crocker, C., Kawauchi, S., Murray, R. C., Shou, J. y Wu, H. H. (2002). Progenitor cells of the olfactory receptor neuron lineage. Microsc Res Tech 58, 176-188.

Candal, E., Anadón, R., DeGrip, W. J. y Rodríguez-Moldes, I. (2005). Patterns of cell proliferation and cell death in the developing retina and optic tectum of the brown trout. Brain Res Dev Brain Res 154, 101-119.

Carrière, C., Plaza, S., Martin, P., Quatannens, B., Bailly, M., Stehelin, D. y Saule, S. (1993). Characterization of quail Pax-6 (Pax-QNR) proteins expressed in the neuroretina. Mol Cell Biol 13, 72577266.

Carrière, C., Plaza, S., Caboche, J., Dozier, C., Bailly, M., Martin, P. y Saule, S. (1995). Nuclear localization signals, DNA binding, and transactivation properties of quail Pax-6 (Pax-QNR) isoforms. Cell Growth Differ 6, 1531-1540.

Carwile, M. E., Culbert, R. B., Sturdivant, R. L. y Kraft, T. W. (1998). Rod outer segment maintenance is enhanced in the presence of bFGF, CNTF and GDNF. Exp Eye Res 66, 791-805.

Castro, A., Becerrra, M., Manso, M. J. y Anadón, R. (2003). Distribution and development of calretinin-like immunoreactivity in the telencephalon of the brown trout, Salmo trutta fario. J Comp Neurol 467, 254-269.

Castro, A., Becerrra, M., Manso, M. J. y Anadón, R. (2006). Calretinin immunoreactivity in the brain of the zebrafish, Danio rerio: distribution and comparison with some neuropeptides and neurotransmittersynthesizing enzymes. II. Midbrain, hindbrain and spinal cord. J Comp Neurol 494, 792-814. 
Cederlund, M. L., Morrissey, M. E., Baden, T. Scholz, D., Vendrell, V., Lagnado, L., Connaughton, V. P. y Kennedy, B. N. (2011). Zebrafish $\operatorname{Tg}(7.2 \mathrm{mab} 2112$ :EGFP)ucd2 transgenics reveal a unique population of retinal amacrine cells. Invest Ophthalmol Vis Sci 52, 1613-1621.

Cerveny, K., Varga, M. y Wilson, S. (2012). Continued growth and circuit building in the anamniote visual system. Dev Neurobiol 72, 328-345.

Chen, H. L., Yuh, C. H. y Wu, K. K. (2010). Nestin is essential for zebrafish brain and eye development through control of progenitor cell apoptosis. PLoS One 5:2, e9318.

Chen, L., Yang, P. y Kijlstra, A. (2002). Distribution, markers, and functions of retinal microglia. Ocular Immunology and Inflammation 10, 27-39.

Chen, X., Tolkovsky, A. M. y Herbert, J. (2011). Cell origin and culture history determine successful integration of neural precursor transplants into the dentate gyrus of the adult rat. PLoS One 6, e17072.

Chetverukhin, V. K. y Polenov, A. L. (1993). Ultrastructural radioautographic analysis of neurogenesis in the hypothalamus of the adult frog, Rana temporaria, with special reference to physiological regeneration of the preoptic nucleus. I. Ventricular zone cell proliferation. Cell Tissue Res 271, 341-350.

Chiang, Y. H., Silani, V. y Zhou, F. C. (1996). Morphological differentiation of astroglial progenitor cells from EGF-responsive neurospheres in response to fetal calf serum, basic fibroblast growth factor, and retinol. Cell Transplant 5, 179-189.

Chiu, J. F., Mack, A. F. y Fernals, R. D. (1995). Daily rhythm of cell proliferation in the teleost retina. Brain Res 673, 119-125.

Chow, R. L., Altmann, C. R., Lang, R. A. y Hemmati-Brivanlou, A. (1999). Pax6 induces ectopic eyes in a vertebrate. Development 126, 42134222 .

Chow, R. L. y Lang, R. A. (2001). Early eye development in vertebrates. Annu Rev Cell Dev Biol 17, 255-296.

Cid, E., Velasco, A., Ciudad, J., Orfao, A., Aijón, J. y Lara, J. M. (2002). Quantitative evaluation of the distribution of proliferating cells in the adult retina in three cyprinid species. Cell Tissue Res $\mathbf{3 0 8}$, $47-59$.

Cid, E. (2006). Participación de las poblaciones proliferativas y de factores de transcripción en el crecimiento continuado y la regeneración del sistema visual de teleósteos. Tesis Doctoral, Universidad de Salamanca.

Cid, E., Santos-Ledo, A., Parrilla-Monge, M., Lillo, C., Arévalo, R., Lara, J. M., Aijón, J. y Velasco, A. (2010). Prox1 expression in rod precursors and Müller cells. Exp Eye Res 90, 267-276.
Clarke, S. R., Shetty, A. K., Bradley, J. L. y Turner, D. A. (1994). Reactive astrocytes express the embryonic intermediate neurofilament nestin. Neuroreport 5, 1885-1888.

Clemente, D., Porteros, A., Arenzana, F. J., Aijón, J., Parrilla, M., Santos-Ledo, A. y Arévalo, R. (2008). Characterization of NADPHdiaphorase-positive glial cells of the tench optic nerve after axotomy. Arch Ital Biol 146, 35-52.

Coles, B. L., Angénieux, B., Inoue, T., Del RioTsonis, K., Spence, J. R., McInnes, R. R., Arsenijevic, Y. y van der Kooy, D. (2004). Facile isolation and the characterization of human retinal stem cells. Proc Natl Acad Sci USA 101, 1577215777 .

Coles, B. L. y van der Kooy, D. (2010). Isolation of retinal stem cells from the mouse eye. J Vis Exp 43, doi: $10.3791 / 2209$.

Collin, S. P., Collin, H. B. y Ali, M. A. (1996). Fine structure of the retina and pigment epithelium in the creek chub, Semotilus atromaculatus (cyprinidae, teleostei). Histol Histopathol 11, 41-53.

Connaughton, V. P., Graham, D. y Nelson, R. (2004). Identification and morphological classification of horizontal, bipolar, and amacrine cells within the zebrafish retina. J Comp Neurol 477, 371-385.

Cook, T., Pichaud, F., Sonneville, R., Papatsenko, D. y Desplan, C. (2003). Distinction between color photoreceptor cell fates is controlled by Prospero in Drosophila. Dev Cell 4, 853-864.

Coutts, J. C. y Gallagher, J. T. (1995). Receptors for fibroblast growth factors. Immunol Cell Biol 73, $584-589$.

Craig, S. E., Thummel, R., Ahmed, H., Vasta, G. R., Hyde, D. R. y Hitchcock, P. F. (2010). The zebrafish galectin Drgal1-12 is expressed by proliferating Müller glia and photoreceptor progenitors and regulates the regeneration of rod photoreceptors. Invest Ophtalmol Vis Sci 51, 3244-3252.

Cwinn, M. A., Mazerolle, C., McNeill, B., Ringuette, R., Thurig, S., Hui, C. C. y Wallace, V. A. (2011). Suppressor of fused is required to maintain the multipotency of neural progenitor cells in the retina. J Neurosci 31, 5169-5180.

Dahlstrand, J., Lardelli, M. y Lendahl, U. (1995). Nestin mRNA expression correlates with the central nervous system progenitor cell state in many, but not all, regions of developing central nervous system. Brain Res Dev Brain Res 84, 109-129.

Dakubo, G. D., Beug, S. T., Mazerolle, C. J., Thurig, S., Wang, Y. y Wallace, V. A. (2008). Control of glial precursor cell development in the mouse optic nerve by sonic hedgehog from retinal ganglion cells. Brain Res 1228, 27-42. 
D'Amour, K. A. y Gage, F. H. (2003). Genetic and functional differences between multipotent neural and pluripotent embryonic stem cells. Proc Natl Acad Sci USA 100, 11866-11872.

Dawid, I. B., Toyama, R. y Taira, M. (1995). LIM domain proteins. CR Acad Sci III 318, 295-306.

De Marzo, A., Aruta, C. y Marigo, V. (2010) PEDF promotes retinal neurosphere formation and expansion in vitro. Adv Exp Med Biol 664, 621-630.

Deguchi, T., Fujimori, K. E., Kawasaki, T., Ohgushi, H. y Yuba, S. (2009). Molecular cloning and gene expression of the proxla and prox1b genes in the medaka, Oryzias latipes. Gene Expr Patterns 9, 341-347.

Del Rio-Tsonis, K., Washabaugh, C. H. y Tsonis, P. A. (1995). Expression of pax-6 during urodele eye development and lens regeneration. Proc Natl Acad Sci USA 92, 5092-5096.

Del Rio-Tsonis, K., Tomarev, S. I. y Tsonis, P. A. (1999). Regulation of Prox 1 during lens regeneration. Invest Ophthalmol Vis Sci 40, 2039-2045.

Delacour, A., Nepote, V., Trumpp, A. y Herrera, P. L. (2004). Nestin expression in pancreatic exocrine cell lineages. Mech Dev 121, 3-14.

Demidenko, Z., Badenhorst, P., Jones, T., Bi, X. y Mortin, M. A. (2001). Regulated nuclear export of the homeodomain transcription factor Prospero. Development 128, 1359-1367.

Díaz, B., Serna, J., De Pablo, F. y de la Rosa, E. J. (2000). In vivo regulation of cell death by embryonic (pro)insulin and the insulin receptor during early retinal neurogenesis. Development $\mathbf{1 2 7}$, 1641-1649.

Distler, C., Weigel, H. y Hoffmann, K. P. (1993) Glia cells of the monkey retina I. astrocytes. J Comp Neurol 333, 134-147.

Djamgoz, M. B., Spadavecchia, L., Usai, C. y Vallerga, S. (1990). Variability of light-evoked response pattern and morphological characterization of amacrine cells in goldfish retina. J Comp Neurol 301, 171-190.

Djamgoz, M. B., Krasowka, M., Martinoli, O., Sericano, M., Vallerga, S. y Grzywna, Z. J. (2001). Structure-function correlation in transient amacrine cells of goldfish retina: basic and multifractal analyses of dendritic trees in distinct synaptic layers. $J$ Neurosci 66, 1208-1216.

Doetsch, F., Caillé, I., Lim, D. A., GarcíaVerdugo, J. M. y Alvarez-Buylla, A. (1999). Subventricular zone astrocytes are neural stem cells in the adult mammalian brain. Cell 97, 703-716.
Dorrell, M. I., Aquilar, E. y Friedlander, M. (2002). Retinal vascular development is mediated by endothelial filopodia, a preexisting astrocytic template and specific R-cadherin adhesion. Invest Ophtalmol Vis Sci 43, 3500-3510.

Douglas, R. H. y Wagner, H. J. (1982). Endogenous patterns of photomechanical movements in teleosts and their relation to activity rhythms. Cell Tissue Res 226, 133-144.

Dowling, J. E. y Ehinger, B. (1978). The interplexiform cell systems. I. Synapses of the dopaminergic neurons of the goldfish retina. Proc $R$ Soc Lond $B$ Biol Sci 201, 7-26.

Duittoz, A. H. y Hevor, T. (2001). Primary culture of neural precursors from the ovine central nervous system (CNS). J Neurosci Methods 107, 131-140.

Duncan, M. K., Cui, W., Oh, D. J. y Tomarev, S. I. (2002). Prox1 is differentially localized during lens development. Mech Dev 112, 195-198.

Duparc, R. H., Abdouh, M., David, J., Lépine, M., Tétreault, N. y Bernier, G. (2007). Pax6 controls the proliferation rate of neuroepithelial progenitors from the mouse optic vesicle. Dev Biol 301, $374-387$.

Durbec, P., Franceschini, I., Lazarini, F. y Dubois-Dalcq, M. (2008). In vitro migration assays of neural stem cells. Methods Mol Biol 438, 213-225.

Dyer, M. A., Livesey, F. J., Cepko, C. L. y G, O. (2003). Prox1 function controls progenitor cell proliferation and horizontal cell genesis in the mammalian retina. Nat Genet 34, 53-58.

Easter, S. J., Johns, P. R. y Baumann, L. R. (1977). Growth of the adult goldfish eye I: Optics. Vision Res 17, 469-477.

Easter, S. J. y Stuermer, C. A. (1984). An evaluation of the hypothesis of shifting terminals in goldfish optic tectum. J Neurosci 4, 1052-1063.

Easter, S. J., Bratton, B. y Scherer, S. S. (1984). Growth-related order of the retinal fiber layer in goldfish. J Neurosci 4, 2173-2190.

Easter, S. S. (1983). Postnatal neurogenesis and changing connections. Treds Neurosci 6, 53-56.

Easter, S. S. (1992). Retinal growth in foveated teleosts: nasotemporal asymmetry keeps the fovea in temporal retina. J Neurosci 12, 2381-2392.

Edqvist, P. H. y Halböök, F. (2004). Newborn horizontal cells migrate bi-directionally across the neuroepithelium during retinal development. Development 131, 1343-1351. 
Edqvist, P. H., Myers, S. M. y Hallböök, F. (2006) Early identification of retinal subtypes in the developing, pre-laminated chick retina using the transcription factors Prox1, Lim1, Ap2alpha, Pax6, Isl1, Isl2, Lim3 and Chx10. Eur J Histochem 50, 147-154.

Edqvist, P. H., Lek, M., Boije, H., Lindbäck, S. M. y Hallböök, F. (2008). Axon-bearing and axon-less horizontal cell subtypes are generated consecutively during chick retinal development from progenitors that are sensitive to follistatin. $B M C D e v$ Biol 8:46

Ehinger, B., Zucker, C. L., Bruun, A. y Adolph, A. (1994). In vivo staining of oligodendroglia in the rabbit retina. Glia $\mathbf{1 0}, 40-48$.

Eiraku, M. y Sasai, Y. (2011). Mouse embryonic stem cell culture for generation of three-dimensional retinal and cortical tissues. Nat Protoc 7, 69-79.

Ekström, P., Johnsson, C. y Ohlin, L. (2001). Ventricular proliferation zones in the brain of an adult teleost fish and their relation to neuromeres and migration (secondary matrix) zones. J Comp Neurol 436, $92-110$

Ellis, P., Fagan, B. M., Magness, S. T., Hutton, S., Taranova, O., Hayashi, S., McMahon, A., Rao, M. y Pevny, L. (2004). Sox2, a persistent marker for multipotential neural stem cells derived from embryonic stem cells, the embryo or the adult. Dev Neurosci 26, 148-165.

Elshatory, Y., Deng, M., Xie, X. y Gan, L. (2007a) Expression of the LIM-homeodomain protein Isl1 in the developing and mature mouse retina. J Comp Neurol 503, 182-197.

Elshatory, Y., Everhart, D., Deng, M., Xie, X., Barlow, R. B. y Gan, L. (2007b). Islet-1 controls the differentiation of retinal bipolar and cholinergic amacrine cells. J Neurosci 27, 12707-12720.

Engelhardt, M., Wachs, F. P., Couillard-Despres, S. y Aigner, L. (2004). The neurogenic competence of progenitors from the postnatal rat retina in vitro. Exp Eye Res 78, 1025-1036.

Ericson, J., Thor, S., Edlund, T., Jessell, T. M. y Yamada, T. (1992). Early stages of motor neuron differentiation revealed by expression of homeobox gene Islet-1. Science 256, 1555-1560.

Ericson, J., Rashbass, P., Schedl, A., BrennerMorton, S., Kawakami, A., van Heyningen, V., Jessell, T. M. y Briscoe, J. (1997). Pax6 controls progenitor cell identity and neuronal fate in response to graded Shh signaling. Cell 90, 169-180.

Faillace, M. P., Julian, D. y Korenbrot, J. I. (2002). Mitotic activation of proliferative cells in the inner nuclear layer of the mature fish retina: regulatory signals and molecular markers. J Comp Neurol 451, 127-141.
Famiglietti, E. V. y Kolb, H. (1976). Structural basis for on and off center responses in retinal ganglion cells. Science 194, 193-195.

Fang, M., Hu, Z., Li, Y., Li, J., Yew, D. T. y Ling, S. (2009). Nestin positive cells in the retina and spinal cord of the sturgeon after hypoxia. Int $J$ Neurosci 119, 460-470.

Fantes, J., Ragge, N. K., Lynch, S. A., McGill, N. I., Collin, J. R., Howard-Peebles, P. N., Hayward, C., Vivian, A. J., Williamson, K., van Heyningen, V. y FitzPatrick, D. R. (2003). Mutations in SOX2 cause anophthalmia. Nat Genet 33, 461-463.

Favaro, R., Valotta, M., Ferri, A. L., Latorre, E., Mariani, J., Giachino, C., Lancini, C., Tosetti, V., Ottolenghi, S., Taylor, V. y Nicolis, S. K. (2009). Hippocampal development and neural stem cell maintenance require Sox2-dependent regulation of Shh. Nat Neurosci 12, 1248-1256.

Ferrari, S., Harley, V. R., Pontiggia, A., Goodfellow, $\mathbf{P} \mathbf{N}$ abd Lovell-Badge, R. y Bianchi, M. E. (1992). SRY, like HMG1, recognizes sharp angles in DNA. EMBO J 11, 4497-4506.

Ferreiro-Galve, S., Rodríguez-Moldes, I. y Candal, E. (2010). Calretinin immunoreactivity in the developing retina of sharks: comparison with cell proliferation and GABAergic system markers. Exp Eye Res 91, 378-386.

Ferreiro-Galve, S., Rodríguez-Moldes, I. y Candal, E. (2012). Pax6 expression during retinogenesis in sharks: comparison with markers of cell proliferation and neuronal differentiation. J Exp Zool B Mol Dev Evol 318, 91-108.

Ferri, A. L., Cavallaro, M., Braida, D., Di Cristofano, A., Canta, A., Vezzani, A., Ottolenghi, S., Pandolfi, P. P., Sala, M., DeBiasi, S. y Nicolis, S. K. (2004). Sox2 deficiency causes neurodegeneration and impaired neurogenesis in the adult mouse brain. Development 131, 3805-3819.

Fischer, A. J. y Reh, T. A. (2000). Identification of a proliferating marginal zone of retinal progenitors in postnatal chickens. Dev Biol 220, 197-210.

Fischer, A. J., Dierks, B. D. y Reh, T. A. (2002a). Exogenous growth factors induce the production of ganglion cells at the retinal margin. Development 129, 2283-2291.

Fischer, A. J., McGuire, C. R., Dierks, B. D. y Reh, T. A. (2002b). Insulin and fibroblast growth factor 2 activate a neurogenic program in Müller glia of the chicken retina. J Neurosci 22, 9387-9398.

Fischer, A. J. y Reh, T. A. (2003). Growth factors induce neurogenesis in the ciliary body. Dev Biol 259, $225-240$. 
Fischer, A. J., Wang, S. Z. y Reh, T. A. (2004) NeuroD induces the expression of visinin and calretinin by proliferating cells derived from toxin-damaged chicken retina. Dev Dyn 229, 555-563.

Fischer, A. J. y Omar, G. (2005). Transitin, a nestinrelated intermediate filament, is expressed by neural progenitors and can be induced in Müller glia in the chicken retina. J Comp Neurol 484, 1-14.

Fischer, A. J., Skorupa, D., Schonberg, D. L. y Walton, N. A. (2006). Characterization of glucagonexpressing neurons in the chicken retina. J Comp Neurol 496, 479-494.

Fischer, A. J., Stanke, J. J., Aloisio, G., Hoy, H. y Stell, W. K. (2007). Heterogeneity of horizontal cells in the chicken retina. J Comp Neurol 500, 11541171.

Fischer, A. J., Zelinka, C. y Scott, M. A. (2010a). Heterogeneity of glia in the retina and optic nerve of birds and mammals. PLoS One 5, e10774.

Fischer, A. J., Scott, M. A., Zelinka, C. y Sherwood, P. (2010b). A novel type of glial cell in the retina is stimulated by insulin-like growth factor 1 and may exacerbate damage to neurons and Müller glia. Glia 58, 633-649.

Font, E., Desfilis, E., Pérez-Cañellas, M. M. y García-Verdugo, J. M. (2001). Neurogenesis and neuronal regeneration in the adult reptilian brain. Brain Behav Evol 58, 276-295.

Francisco-Morcillo, J., Hidalgo-Sánchez, M. y Martín-Partido, G. (2006). Spatial and temporal patterns of proliferation and differentiation in the developing turtle eye. Brain Res 1103, 32-48.

Freeman, N. E., Templeton, J. P., Orr, W. E., Lu, L., Williams, R. W. y Geisert, E. E. (2011). Genetic networks in the mouse retina: growth associated protein 43 and phosphatase tensin homolog network. Mol Vis 17, 1355-1372.

Friedman, M. A. y Kawasaki, M. (1997). Calretininlike immunoreactivity in mormyrid and gymnarchid electrosensory and electromotor systems. J Comp Neurol 387, 341-357.

Fuccillo, M., Joyner, A. L. y Fishell, G. (2006). Morphogen to mitogen: the multiple roles of hedgehog signalling in vertebrate neural development. Sig Devel 7, $772-783$

Galli-Resta, L., Resta, G., Tan, S. S. y Reese, B. E. (1997). Mosaics of islet-1-expressing amacrine cells assembled by short-range cellular interactions. $J$ Neurosci 17, 7831-7838.

Gamm, D. M., Wright, L. S., Capowski, E. E., Shearer, R. L., Meyer, J. S., Kim, H. J., Schneider, B. L., Melvan, J. N. y Svendsen, C. N. (2008). Regulation of prenatal human retinal neurosphere growth and cell fate potential by retinal pigment epithelium and Mash1. Stem Cells 26, 3182-3193.
García-Crespo, D. y Vecino, E. (2004). Differential expression of calretinin in the developing and regenerating zebrafish visual system. Histol Histopathol 19, 1193-1199.

Gariano, R. F. (2003). Cellular mechanisms in retinal vascular development. Progr Retin Eye Res 22, 295306.

Gastinger, M. J., Singh, R. S. y Barber, A. J. (2006). Loss of cholinergic and dopaminergic amacrine cells in streptozotocin-diabetic rat and Ins2Akitadiabetic mouse retinas. Invest Ophthalmol Vis Sci 47, 3143-3150

Gaur, V. P., Liu, Y. y Turner, J. E. (1992). RPE conditioned medium stimulates photoreceptor cell survival, neurite outgrowth and differentiation in vitro. Exp Eye Res 54, 645-659.

Geneser, F. (1993). Histología. Capítulo: El ojo. Editorial médica panamericana.

Gerhard, G. S., Kauffman, E. J., Wang, X., Stewart, R., Moore, J. L., Kasales, C. J., Demidenko, E. y Cheng, K. C. (2002). Life spans and senescent phenotypes in two strains of zebrafish $(D a-$ nio rerio). Exp Gerontol 37, 1055-1068.

Gilyarov, A. V. (2008). Nestin in central nervous system cells. Neurosci Behav Physiol 38, 165-169.

Giordano, F., De Marzo, A., Vetrini, F. y Marigo, V. (2007). Fibroblast growth factor and epidermal growth factor differently affect differentiation of murine retinal stem cells in vitro. Mol Vis 13, 18421850 .

Glasgow, E. y Tomarev, S. I. (1998). Restricted expression of the homeobox gene prox 1 in developing zebrafish. Mech Dev 76, 175-178.

Godinho, L., Williams, P. R., Claassen, Y., Provost, E., Leach, S. D., Kamermans, M. y Wong, R. O. (2007). Nonapical symmetric divisions underlie horizontal cell layer formation in the developing retina in vivo. Neuron 56, 597-603.

Gómez, A., Volff, J. N., Hornung, U., Schartl, M. y Wellbrock, C. (2004). Identification of a second egfr gene in Xiphophorus uncovers an expansion of the epidermal growth factor receptor family in fish. Mol Biol Evol 21, 266-275.

González-Curto, G. (2010). Neurogénesis y gliogénesis en el cerebro rostral del ratón adulto heterocigoto para Pax6 (+/SeyDey). Tesis Doctoral, Universidad de Salamanca.

Graham, V., Khudyakov, J., Ellis, P. y Pevny, L. (2003). Sox2 functions to maintain neural progenitor identity. Neuron 39, 749-765.

Grün, G. (1975). Structural basis of the functional development of the retina in the cichlid Tilapia leucosticta (teleostei). J Embryol Exp Morphol 33, 243257. 
Gu, H., Wang, S., Messam, C. A. y Yao, Z. (2002) Distribution of nestin immunoreactivity in the normal adult human forebrain. Brain Res 943, 174-180.

Gu, P., Harwood, L. J., Zhang, X., Wylie, M. Curry, W. J. y Cogliati, T. (2007). Isolation of retinal progenitor and stem cells from the porcine eye. Mol Vis 13, 1045-1057.

Guduric-Fuchs, J., Ringland, L. J., Gu, P., Dellett, M., Archer, D. B. y Cogliati, T. (2009). Immunohistochemical study of pig retinal development. Mol Vis 15, 1915-1928.

Hack, M. A., Sugimori, M., Lundberg, C., Nakafuku, M. y Götz, M. (2004). Regionalization and fate specification in neurospheres: the role of Olig2 and Pax6. Mol Cell Neurosci 25, 664-678.

Halder, G., Callaerts, P. y Gehring, W. J. (1995) Induction of ectopic eyes by targeted expression of the eyeless gene in Drosophila. Science 267, 1788-1792.

Hami, D., Grimes, A. C., Tsai, H. J. y Kirby, M. L. (2011). Zebrafish cardiac development requires a conserved secondary heart field. Development 139 2389-2398.

Han, Y. G., Spassky, N., Romaguera-Ros, M. García-Verdugo, J. M., Aguilar, A., SchneiderMaunoury, S. y Alvarez-Buylla, A. (2008). Hedgehog signaling and primary cilia are required for the formation of adult neural stem cells. Nat Neurosci 11, 277-284.

Hartong, D. T., Berson, E. L. y Dryja, T. P. (2006). Retinitis pigmentosa. Lancet 368, 1795-1809.

Haslinger, A., Schwarz, T. J., Covic, M. y Lie, C. (2009). Expression of Sox11 in adult neurogenic niches suggests a stage-specific role in adult neurogenesis. Eur J Neurosci 29, 2103-2114.

Haverkamp, S., Haeseleer, F. y Hendrickson, A. (2003). A comparison of immunocytochemical markers to identify bipolar cell types in human and monkey retina. Vis Neurosci 20, 589-600.

Hawryshyn, C. W., Moyer, H. D., Allison, W. T., Haimberger, T. J. y McFarland, W. N. (2003) Multidimensional polarization sensitivity in damselfishes. J Comp Physiol A Neuroethol Sens Neural Behav Physiol 189:3, 213-220.

Hayes, B. P. y Holden, A. L. (1983). The distribution of displaced ganglion cells in the retina of the pigeon. Exp Brain Res 49, 181-188.

Haynes, L. W. (1988). Fibroblast (heparin-binding) growing factors in neuronal development and repair. Mol Neurobiol 2, 263-289.

Heberlein, U., Singh, C. M., Luk, A. Y. y Donohoe, T. J. (1995). Growth and differentiation in the Drosophila eye coordinated by hedgehog. Nature 373, 709-711.
Hendzel, M. J., Wei, Y., Mancini, M. A., Van Hooser, A., Ranalli, T., Brinkley, B. R., Bazett-Jones, D. P. y D, A. C. (1997). Mitosisspecific phosphorylation of histone H3 initiates primarily within pericentromeric heterochromatin during G2 and spreads in an ordered fashion coincident with mitotic chromosome condensation. Chromosoma 106, 348-360.

Henken, D. B. y Yoon, M. G. (1989). Optic nerve crush modulates proliferation of rod precursor cells in the goldfish retina. Brain Res 501, 247-259.

Herbst, R. S. (2004). Review of epidermal growth factor receptor biology. Int J Radiat Oncol Biol Phys 59, 21-26.

Hever, A. M., Williamson, K. A. y van Heyningen, V. (2006). Developmental manlformatios of the eye: the role of Pax6, Sox2 and Otx2. Clin Genet 69, 459-470.

Hicks, D. y Courtois, Y. (1992). Fibroblast growth factor stimulates photoreceptor differenciation in vitro. J Neurosci 12, 2022-2033.

Hidalgo, A. y Griffiths, R. (2004). Coupling glial numbers and axonal patterns. Cell Cycle 3, 11181120.

Hinsch, K. y Zupanc, G. K. (2006). Isolation, cultivation, and differentiation of neural stem cells from adult fish brain. J Neurosci Methods 158, 75-88.

Hirsch, N. y Harris, W. A. (1997). Xenopus pax-6 and retinal development. J Neurobiol 32, 45-61.

Hitchcock, P. y Kakuk-Atkins, L. (2004). The basic helix-loop-helix transcription factor neuroD is expressed in the rod lineage of the teleost retina. $J$ Comp Neurol 477, 108-117.

Hitchcock, P., Ochocinska, M., Sieh, A. y Otteson, D. (2004). Persistent and injury-induced neurogenesis in the vertebrate retina. Prog Retin Eye Res 23, 183-194.

Hitchcock, P. F. y Easter, S. J. (1986). Retinal ganglion cells in goldfish: a qualitative classification into four morphological types, and a quantitative study of the development of one of them. J Neurosci 6, 10371050 .

Hitchcock, P. F., Macdonald, R. E., VanDeRyt, J. T. y Wilson, S. W. (1996). Antibodies against pax6 immunostain amacrine and ganglion cells and neuronal progenitors, but not rod precursors, in the normal and regenerating retina of the goldfish. $\mathrm{J} \mathrm{Neu-}$ robiol 29, 399-413.

Hockfield, S. y McKay, R. D. (1985). Identification of major cell classes in the developing mammalian nervous system. J Neurosci 5, 3310-3328. 
Hodel, C., Neuhauss, S. C. y Biehlmaier, O (2006). Time course and development of light adaptation processes in the outer zebrafish retina. Anat Rec A Discov Mol Cell Evol Biol. 288:6, 653-662.

Hoke, K. L. y Fernald, R. D. (1997). Rod photoreceptor neurogenesis. Prog Retin Eye Res 16, 31-49.

Hollborn, M., Ulbricht, E., Rillich, K., DukicStefanovic, S., Wurm, A., Wagner, L., Reichenbach, A., Wiedemann, P., Limb, G. A., Bringmann, A. y Kohen, L. (2011). The human Müller cell line MIO-M1 expresses opsins. Mol Vis 17, 2738-2750.

Hollyfield, J. G. (1968). Differential addition of cells to the retina in Rana pipiens tadpoles. Dev Biol 18, 163-179.

Homman-Ludiye, J., Merson, T. D. y Bourne, J. A. (2012). The early postnatal nonhuman primate neocortex contains self-renewing multipotent neural progenitor cells. PLoS One 7, e34383.

Hsieh, Y. W. y Yang, X. J. (2009). Dynamic Pax6 expression during the neurogenic cell cycle influences proliferation and cell fate choices of retinal progenitors. Neural Dev 4:32.

Hu, J., Tang, S. B., Ma, J., Wu, J. L. y Shen, H. X. (2007). Experimental studies on the existence and distribution characteristics of neural stem cells in adult human ciliary body and retina. Zhonghua Yan Ke Za Zhi 43, 222-227.

Huang, X., Hui, M. N., Liu, Y., Yuen, D. S., Zhang, Y., Chan, W. Y., Lin, H. R., Cheng, S. H. y Cheng, C. H. (2009). Discovery of a novel prolactin in non-mammalian vertebrates: evolutionary perspectives and its involvement in teleost retina development. PLoS One 4, e6163.

Hughes, A. y Wieniawa-Narkiewicz, E. (1980). A newly identified population of presumtive microneurones in the cat retinal ganglion cell layer. Nature 284, 468-470.

Ihrie, R. A., Shah, J. K., Harwell, C. C., Levine, J. H., Guinto, C. D., Lezameta, M., Kriegstein, A. R. y Alvarez-Buylla, A. (2011). Perstistent sonic hedgehog signaling in the adult brain determines neural stem cell positional identity. Neuron 71, 250262 .

Ingham, P. W., Taylor, A. M. y Nakano, Y. (1991). Role of the Drosophila patched gene in positional signalling. Nature 353, 184-187.

Inoue, M., Kamachi, Y., Matsunami, H., Imada, K., Uchikawa, M. y Kondoh, H. (2007). PAX6 and SOX2-dependent regulation of the Sox2 enhancer N-3 involved in embryonic visual system development. Genes Cells 12, 1049-1061.
Ito, Y., Tanaka, H., Okamoto, H. y Ohshima, T. (2010). Characterization of neural stem cells and their progeny in the adult zebrafish optic tectum. Dev Biol 342, 26-38.

Jeffery, W., Strickler, A., Guiney, S., Heyser, D. y Tomarev, S. (2000). Prox 1 in eye degeneration and sensory organ compensation during development and evolution of the cavefish Astyanax. Dev Genes Evol 210, 223-230.

Jensen, A. M. y Wallace, V. A. (1997). Expression of sonic hedgehog and its putative role as a precursor cell mitogen in the developing mouse retina. Development 124, 363-371.

Jian, Q., Xu, H., Xie, H., Tian, C., Zhao, T. y Yin, Z. (2009). Activation of retinal stem cells in the proliferating marginal region of rcs rats during development of retinitis pigmentosa. Neurosci Lett 465, 41-44.

Jimeno, D., Velasco, A., Lillo, C., Lara, J. M. y Aijón, J. (1999). Response of microglial cells after a cryolesion in the peripheral proliferative retina of tench. Brain Res 816, 175-189.

Jimeno, D. (2001). Implicaciones de la retina periférica en el crecimiento continuado y la regeneración del sistema visual de teleósteos. Tesis Doctoral, Universidad de Salamanca.

Johns, P. R. y Easter, S. J. (1977). Growth of the adult goldfish eye. II. Increase in retinal cell number. J Comp Neurol 176, 331-341.

Johns, P. R. (1977). Growth of the adult goldfish eye. III. Source of the new retinal cell. J Comp Neurol 176, 343-357.

Johns, P. R. y Fernald, R. D. (1981). Genesis of rods in teleost fish retina. Nature 293, 141-142.

Johns, P. R. (1982). Formation of photoreceptors in larval and adult goldfish. J Neurosci 2, 178-198.

Johnsen, E. O., Frøen, R. C., Albert, R., Omdal, B. K., Sarang, Z., Berta, A., Nicolaissen, B., Petrovski, G. y Moe, M. C. (2012). Activation of neural progenitor cells in human eyes with proliferative vitreoretinopathy. Exp Eye Res 98, 28-36.

Johnston, M. C., Noden, D. M., Hazelton, R. D., Coulombre, J. L. y Coulombre, A. J. (1979). Origins of avian ocular and periocular tissues. Exp Eye Res 29, 27-43.

Jori, F. P., Galderisi, U., Piegari, E., Cipollaro, M., Cascino, A., Peluso, G., Cotrufo, R., Giordano, A. y Melone, M. A. (2003). EGF-responsive rat neural stem cells: molecular follow-up of neuron and astrocyte differentiation in vitro. J Cell Physiol 195, 220-233. 
Julian, D., Ennis, K. y Korenbrot, J. I. (1998) Birth and fate of proliferative cells in the inner nuclear layer of the mature fish retina. J Comp Neurol 394, $271-282$.

Jusuf, P. R. y Harris, W. A. (2009). Ptf1a is expressed transiently in all types of amacrine cells in the embryonic zebrafish retina. Neural Dev 4:34.

Kalloniatis, M. y Marc, R. E. (1990). Interplexiform cells of the goldfish retina. J Comp Neurol 297, 340358 .

Kalyani, A. J., Mujtaba, T. y Rao, M. S. (1999) Expression of EGF receptor and FGF receptor isoforms during neuroepithelial stem cell differentiation. J Neurobiol 38, 207-224.

Kamachi, Y., Uchikawa, M., Collignon, J., LovellBadge, R. y Kondoh, H. (1998). Involvement of Sox1, 2 and 3 in the early and subsequent molecular events of lens induction. Development 125, 25212532 .

Kamachi, Y., Cheah, K. S. y Kondoh, H. (1999). Mechanism of regulatory target selection by the SOX high-mobility-group domain proteins as revealed by comparison of SOX1/2/3 and SOX9. Mol Cell Biol 19, $107-120$.

Kaneko, S., Ueda-Yamada, M., Ando, A., Matsumura, S., Okuda-Ashitaka, E., Matsumura, M., Uyama, M. y Ito, S. (2007). Cytotoxic effect of spermine on retinal pigment epithelial cells. Invest Ophthalmol Vis Sci 48, 455-463.

Kaneko, Y., Matsumoto, G. y Hanyu, Y. (1999). Pax-6 expression during retinal regeneration in the adult newt. Dev Growth Differ 41, 723-729.

Karl, M. O., Hayes, S., Nelson, B. R., Tan, K., Buckingham, B. y Reh, T. A. (2008). Stimulation of neural regeneration in the mouse retina. Proc Natl Acad Sci USA 105, 19508-19513.

Karlsson, O., Thor, S., Norberg, T., Ohlsson, H. y Edlund, T. (1990). Insulin gene enhancer binding protein Isl-1 is a member of a novel class of proteins containing both a homeo- and a Cys-His domain. $\mathrm{Na}$ ture 344, 879-882.

Kaslin, J., Ganz, J., Geffarth, M., Grandel, H., Hans, S. y Brand, M. (2009). Stem cells in the adult zebrafish cerebellum: initiation and maintenance of a novel stem cell niche. J Neurosci 29, 61426153.

Kassen, S. C., Thummel, R., Burket, C. T., Campochiaro, L. A., Harding, M. J. y Hyde, D. R. (2008). The $\mathrm{Tg}$ (ccnb1:EGFP) transgenic zebrafish line labels proliferating cells during retinal development and regeneration. Mol Vis 14, 951-963.

Katakowski, M., Zhang, Z., deCarvalho, A. C. y Chopp, M. (2005). EphB2 induces proliferation and promotes a neuronal fate in adult subventricular neural precursor cells. Neurosci Lett 385, 204-209.
Kawakami, A., Kimura-Kawakami, M., Nomura, T. y Fujisawa, H. (1997). Distributions of pax6 and pax7 proteins suggest their involvement in both early and late phases of chick brain development. Mech Dev 66, 119-130.

Kelley, M. W., Williams, R. C., Turner, J. K., Creech-Kraft, J. M. y Reh, T. A. (1999). Retinoic acid promotes rod photoreceptor differentiation in rat retina in vivo. Neuroreport 10, 2389-2394.

Kempermann, G., Jessberger, S., Steiner, B. y Kronenberg, G. (2004). Milestones of neuronal development in the adult hippocampus. Trends Neurosci 27, 447-452.

Kern, T. S. y Barber, A. J. (2008). Retinal ganglion cells in diabetes. $J$ Physiol 586, 4401-4408.

Kholodenko, I. V., Buzdin, A. A., Kholodenko, R. V., Baibikova, J. A., Sorokin, V. F., Yarygin, V. N. y Sverdlov, E. D. (2006). Mouse retinal progenitor cell (RPC) cocultivation with retinal pigment epithelial cell culture affects features of rpc differentiation. Biochemistry (Mosc) 71, 767-774.

Kissinger, C., Liu, B., Martin-Blanco, E., Kornberg, T. y Pabo, C. O. (1990). Crystal structure of an angrailed homeodomain-DNA complex at 2.8 å resolution: a framework for understanding homeodomain-DNA interactions. Cell 63, 579-590.

Kock, J. H. (1982). Neuronal addition and retinal expansion during growth of the crucian carp eye. $J$ Comp Neurol 209, 264-274.

Kokkinopoulos, I., Pearson, R. A., MacNeil, A., Dhomen, N. S., MacLaren, R. E., Ali, R. R. y Sowden, J. C. (2008). Isolation and characterisation of neural progenitor cells from the adult Chx10(orJ/orJ) central neural retina. Mol Cell Neurosci 38, 359-373.

Kolb, H. (1979). The inner plexiform layer in the retina of the cat: electron microscopic observations. $J$ Neurocytol 8:3, 295-329.

Kolb, H., Fernández, E. y Nelson, R. (2000). Webvision. http://www.webvision.med.utah.edu .

Kolbinger, W., Wagner, D. y Wagner, H. J. (1996). Control of rod retinomotor movements in teleost retinae: the role of dopamine in mediating lightdependent and circadian signals. Cell Tissue Res 285, 445-451.

Komitova, M. y Eriksson, P. S. (2004). Sox2 is expressed by neural progenitors and astroglia in the adult rat brain. Neurosci Lett 369, 24-27.

Korzh, V., Edlund, T. y Thor, S. (1993). Zebrafish primary neurons initiate expression of the LIM homeodomain protein Isl-1 at the end of gastrulation. Development 118, 417-425. 
Korzh, V., Sleptsova, I., Liao, J., He, J. y Gong, Z. (1998). Expression of zebrafish bHLH genes ngn1 and nrd defines distinct stages of neural differentiation. Dev Dyn 213, 92-104.

Koutsopoulos, S. y Zhang, S. (2013). Long-term three-dimensional neural tissue cultures in functionalized self-assembling peptide hydrogels, matrigel and collagen I. Acta Biomater 7061, 5162-5169.

Krauss, S., Johansen, T., Korzh, V., Moens, U., Ericson, J. U. y Fjose, A. (1991). Zebrafish pax[zfa]: a paired box-containing gene expressed in the neural tube. EMBO J 10, 3609-3619.

Kubota, R., Hokoc, J. N., Moshiri, A., McGuire, C. y A, R. T. (2002). A comparative study of neurogenesis in the retinal ciliary marginal zone of homeothermic vertebrates. Brain Dev Brain Res 134, $31-41$

Kuhn, H. G., Winkler, J., Kempermann, G. Thal, L. J. y Gage, F. H. (1997). Epidermal growth factor and fibroblast growth factor-2 have different effects on neural progenitors in the adult rat brain. J Neurosci 17, 5820-5829.

Kukekov, V. G., Laywell, E. D., Thomas, L. B. y Steindler, D. A. (1997). A nestin-negative precursor cell from the adult mouse brain gives rise to neurons and glia. Glia 21, 399-407.

Kukekov, V. G., Laywell, E. D., Suslov, O., Davies, K., Scheffler, B., Thomas, L. B., O'Brien, T. F., Kusakabe, M. y Steindler, D. A. (1999). Multipotent stem/progenitor cells with similar properties arise from two neurogenic regions of adult human brain. Exp Neurol 156, 333-344.

Kwan, J. W., Lee, M. J., Mack, A. F., Chiu, J. F. y Fernald, R. D. (1996). Nonuniform distribution of cell proliferation in the adult teleost retina. Brain Res 712, 40-44.

Lai, K., Kaspar, B. K., Gage, F. H. y Schaffer, D. V. (2003). Sonic hedgehog regulates adult neural progenitor proliferation in vitro and in vivo. Nat Neurosci 6, 21-27.

Laisney, J. A., Braasch, I., Walter, R. B., Meierjohann, S. y Schartl, M. (2010). Lineage-specific co-evolution of the Egf receptor/ligand signaling system. BMC Evol Biol 10, 27.

Lakowski, J., Majumder, A. y Lauderdale, J. D. (2007). Mechanisms controlling Pax6 expression in the retina have been conserved between teleosts and mammals. Dev Biol 307, 498-520.

Lamba, D. A., McUsic, A., Hirata, R. K., Wang, P. R., Russell, D. y Reh, T. A. (2010). Generation, purification and transplantation of photoreceptors derived from human induced pluripotent stem cells. PLoS One 5, e8763.
Lavado, A. y Oliver, G. (2007). Prox1 expression patterns in the developing and adult murine brain. Dev Dyn 236, 518-524.

Lavado, A., Lagutin, O. V., Chow, L. M., Baker, S. J. y Oliver, G. (2010). Prox1 is required for granule cell maturation and intermediate progenitor maintenance during brain neurogenesis. PLoS Biol 8 , e1000460.

Lawrence, J. M., Singhal, S., Bhatia, B., Keegan, D. J., Reh, T. A., Luthert, P. J., Khaw, P. T. y Limb, G. A. (2007). MIO-M1 cells and similar Müller glial cell lines derived from adult human retina exhibit neural stem cell characteristics. Stem Cells 25, 2033-2043.

Lee, J. H., Park, H. S., Shin, J. M., Chun, M. H. y Oh, S. J. (2012). Nestin expressing progenitor cells during establishment of the neural retina and its vasculature. Anat Cell Biol 45, 38-46.

Lehner, B., Sandner, B., Marschallinger, J., Lehner, C., Furtner, T., Couillard-Despres, S., Rivera, F. J., Brockhoff, G., Bauer, H. C., Weidner, N. y Aigner, L. (2011). The dark side of BrdU in neural stem cell biology: detrimental effects on cell cycle, differentiation and survival. Cell Tissue Res 345, 313-328.

Lendahl, U., Zimmerman, L. B. y McKay, R. D. (1990). CNS stem cells express a new class of intermediate filament protein. Cell 60, 585-595.

Lengler, J., Bittner, T., Münster, D., Gawad, A. D. y Graw, J. (2005). Agonistic and antagonistic action of AP2, Msx2, Pax6, Prox1 and Six3 in the regulation of Sox2 expression. Ophthalmic Res 37, 301-309.

Leventhal, A. G., Rodieck, R. W. y Dreher, B. (1981). Retinal ganglion cell classes in the old world monkey: morphology and central projections. Science 213, 1139-1142.

Levine, E. M., Roelink, H., Turner, J. y Reh, T. A. (1997). Sonic hedgehog promotes rod photoreceptor differentiation in mammalian retinal cells in vitro. J Neurosci 17, 6277-6288.

Li, Y. N., Matsui, J. I. y Dowling, J. E. (2009). Specificity of the horizontal cell-photoreceptor connections in the zebrafish (Danio rerio) retina. J Comp Neurol 516, 442-453.

Li, Y. N., Tsujimura, T., Kawamura, S. y Dowling, J. E. (2012). Bipolar cell-photoreceptor connectivity in the zebrafish (Danio rerio) retina. J Comp Neurol 520, 3786-3802.

Li, Z., Hu, M., Ochocinska, M. J., Joseph, N. M. y Easter, S. J. (2000). Modulation of cell proliferation in the embryonic retina of zebrafish (Danio rerio). Dev Dyn 219, 391-401. 
Liard, O., Segura, S., Pascual, A., Gaudreau, P., Fusai, T. y Moyse, E. (2009). In vitro isolation of neural precursor cells from the adult pig subventricular zone. J Neurosci Methods 182, 172-179.

Liem, R. K. (1993). Molecular biology of neuronal intermediate filaments. Curr Opin Cell Biol 5, 12-16.

Lillo, C., Velasco, A., Jimeno, D., Lara, J. M. y Aijón, J. (1998). Ultrastructural organization of the optic nerve of the tench (Cyprinidae, Teleostei). $J$ Neurocytol 27, 593-604.

Lillo, C., Velasco, A., Jimeno, D., Cid, E., Aijón, J. y Lara, J. M. (2001). Non-neuronal cells involved in the degeneration and regeneration of the fish retina. J Neurocytol 30, 475-491.

Lim, J. H., Koh, S., Olby, N. J., Piedrahita, J. y Mariani, C. L. (2012). Isolation and characterization of neural progenitor cells from adult canine brains. Am J Vet Res 73, 1963-1968.

Lima, I. P., Saito, K., Hamassaki, D. E. y Yan, C. (2007). Immunohistochemical characterization of the chick marginal retina. Braz J Med Biol Res 40 , 1455-1464.

Lin, Y. P., Ouchi, Y., Satoh, S. y Watanabe, S. (2009). Sox2 plays a role in the induction of amacrine and Müller glial cells in mouse retinal progenitor cells. Invest Ophthalmol Vis Sci 50, 68-74.

Liu, I. H., Chen, S. J., Ku, H. H., Kao, C. L., Tsai, F. T., Hsu, W. M., Lo, C. W., Kuo, Y. H., Kuo, C. D., Lee, C. H. y Chiou, S. H. (2005). Comparison of the proliferation and differentiation ability between adult rat retinal stem cells and cerebral cortex-derived neural stem cells. Ophthalmologica 219, 171-176.

Luna, G., Lewis, G. P., Banna, C. D., Skalli, O. y Fisher, S. K. (2010). Expression profiles of nestin and synemin in reactive astrocytes and Müller cells following retinal injury: a comparison with glial fibrillar acidic protein and vimentin. Mol Vis 16, 2511-2523.

Lyall, A. H. (1957). The growth of the trout retina. $Q$ J Microsc Sci 98, 101-110.

Mack, A. F. y Fernald, R. D. (1993). Regulation of cell division and rod differentiation in the teleost retina. Brain Res Dev Brain Res 76, 183-187.

Mack, A. F., Papanikolaou, D. y Lillo, C. (2003). Investigation of the migration path for new rod photoreceptors in the adult cichlid fish retina. Exp Neurol 184, 90-96.

MacLaren, R. E., Pearson, R. A., MacNeil, A., Douglas, R. H., Salt, T. E., Akimoto, M., Swaroop, A., Sowden, J. C. y Ali, R. R. (2006). Retinal repair by transplantation of photoreceptor precursors. Nature 444, 203-207.
MacNeil, A., Pearson, R. A., MacLaren, R. E., Smith, A. J., Sowden, J. C. y Ali, R. R. (2007). Comparative analysis of progenitor cells isolated from the iris, pars plana, and ciliary body of the adult porcine eye. Stem Cells 25, 2430-2438.

Macy, A. y Easter, S. J. (1981). Growth-related changes in the size of receptive field centers of retinal ganglion cells in goldfish. Vision Res 21, 1497-1504.

Mahler, J. y Driever, W. (2007). Expression of the zebrafish intermediate neurofilament nestin in the developing nervous system and in neural proliferation zones at postembryonic stages. BMC Dev Biol 7:89.

Makariev, E. O., Zinovieva, R. D. y Mitashov, V. I. (2002). Expression of regulatory homeobox genes during retina regeneration in adult newts. Izv Akad Nauk Ser Biol 6, 663-667.

Manning, L. y Doe, C. Q. (1999). Prospero distinguishes sibling cell fate without asymmetric localization in the Drosophila adult external sense organ lineage. Development 126, 2063-2071.

Marc, R. E. y Liu, W. L. (1984). Horizontal cell synapses onto glycine-accumulating interplexiform cells. Nature 312, 266-269.

Marc, R. E. (1998). The retinal basis of vision. Capítulo: The structure of vertebrate retinas. Amsterdam: Elservier Science BV, páginas 3-19.

Marc, R. E. y Cameron, D. (2001). A molecular phenotype atlas of the zebrafish retina. J Neurocytol 30, 593-654.

Marchena, M., Lara, J., Aijón, J., Germain, F., de la Villa, P. y A, V. (2011). The retina of the PCD/PCD mouse as a model of photoreceptor degeneration. a structural and functional study. Exp Eye Res 93, 607-617.

Marcus, R. C., Delaney, C. L. y Easter, S. J. (1999). Neurogenesis in the visual system of embryonic and adult zebrafish (Danio rerio). Visual Neurosci 16, 417-424

Markitantova, Y. V., Makariev, E. O., Pavlova, G. V., Zinovieva, R. D. y Mitashov, V. I. (2003). Location of the Prox1 gene expression during newt lens and retina regeneration. Dokl Biol Sci 391, 361364 .

Marquardt, T., Ashery-Padan, R., Andrejewski, N., Scardigli, R., Guillemot, F. y Gruss, P. (2001). Pax6 is required for the multipotent state of retinal progenitor cells. Cell 105, 43-55.

Marshak, D. W. y Dowling, J. E. (1987). Synapses of cone horizontal cell axons in goldfish retina. J Comp Neurol 256, 430-443. 
Martin, P., Carriere, C., Dozier, C., Quatannens, B., Mirabel, M. A., Vandenbunder, B., Stehelin, D. y Saule, S. (1992). Characterization of a paired box- and homeobox-containing quail gene (Pax-QNR) expressed in the neuroretina. Oncogene 7, 1721-1728.

Martínez-Monedero, R., Yi, E., Oshima, K., Glowatzki, E. y Edge, A. S. (2008). Differentiation of inner ear stem cells to functional sensory neurons. Dev Neurobiol 68, 669-684.

Martínez-Navarrete, G. C., Angulo, A., MartínNieto, J. y Cuenca, N. (2008). Gradual morphogenesis of retinal neurons in the peripheral retinal margin of adult monkeys and humans. J Comp Neurol $\mathbf{5 1 1}, 557-580$.

Marvin, M. J., Dahlstrand, J., Lendahl, U. y McKay, R. D. (1998). A rod end deletion in the intermediate filament protein nestin alters its subcellular localization in neuroepithelial cells of transgenic mice. J Cell Sci 111, 1951-1961.

März, M., Chapouton, P., Diotel, N., Vaillant, C., Hesl, B., Takamiya, M., Lam, C. S., Kah, O., Bally-Cuif, L. y Strähle, U. (2010). Heterogeneity in progenitor cell subtypes in the ventricular zone of the zebrafish adult telencephalon. Glia 58, 870-888.

Masai, I., Stemple, D. L., Okamoto, H. y Wilson, S. W. (2000). Midline signals regulate retinal neurogenesis in zebrafish. Neuron 27, 251-263.

Masai, I., Yamaguchi, M., Tonou-Fujimori, N., Komori, A. y Okamoto, H. (2005). The hedgehogpka pathway regulates two distinct steps of the differentiation of retinal ganglion cells: the cell-cycle exit of retinoblasts and their neuronal maturation. Development 132, 1540-1553.

Matsui, K., Hosoi, N. y Tachibana, M. (1999). Active role of glutamate uptake in the synaptic transmission from retinal nonspiking neurons. J Neurosci 19, 6755-6766.

Matsushima, D., Heavner, W. y Pevny, L. H. (2011). Combinatorial regulation of optic cup progenitor cell fate by sox2 and pax6. Development 138, 443-454.

Mayer, E. J., Hughes, E. H., Carter, D. A. y Dick, A. D. (2003). Nestin positive cells in adult human retina and in epiretinal membranes. $\mathrm{Br} J$ Ophtalmol 87, 1154-1158.

Mayer, E. J., Carter, D. A., Ren, Y., Hughes, E. H., Rice, C. M., Halfpenny, C. A., Scolding, N. J. y Dick, A. D. (2005). Neural progenitor cells from postmortem adult human retina. $\mathrm{Br} J$ Ophthalmol 89, 102-106.

McLenachan, S., Lum, M. G., Waters, M. J. y Turnley, A. M. (2009). Growth hormone promotes proliferation of adult neurosphere cultures. Growth Horm IGF Res 19, 212-218.
McNeill, B., Pérez-Iratxeta, C., Mazzerolle, C., Furimsky, M., Mishina, Y., Andrade-Navarro, M. A. y Wallace, V. A. (2012). Comparative genomics identification of a novel set of temporally regulated hedgehog target genes in the retina. Mol Cell Neurosci 49, 333-340.

Merlo, S., Canonico, P. L. y Sortino, M. A. (2011). Distinct effects of pramipexole on the proliferation of adult mouse sub-ventricular zone-derived cells and the appearance of a neuronal phenotype. Neuropharmacology 60, 892-900.

Messam, C. A., Hou, J. y Major, E. O. (2000). Coexpression of nestin in neural and glial cells in the developing human CNS defined by a human-specific anti-nestin antibody. Exp Neurol 161, 585-596.

Meyer, J. S., Howden, S. E., Wallace, K. A., Verhoeven, A. D., Wright, L. S., Capowski, E. E., Pinilla, I., Martin, J. M., Tian, S., Stewart, R., Pattnaik, B., Thomson, J. A. y Gamm, D. M. (2011). Optic vesicle-like structures derived from human pluripotent stem cells facilitate a customized approach to retinal disease treatmen. Stem Cells 29, 1206-1218.

Meyer, R. L. (1978). Evidence from thymidine labeling for continuing growth of retina and tectum in juvenile goldfish. Exp Neurol 59, 99-111.

Miyagi, S., Nishimoto, M., Saito, T., Ninomiya, M., Sawamoto, K., Okano, H., Muramatsu, M., Oguro, H., Iwama, A. y Okuda, A. (2006). The Sox2 regulatory region 2 functions as a neural stem cell-specific enhancer in the telencephalon. $J$ Biol Chem 281, 13374-13381.

Moe, M. C., Kolberg, R. S., Sandberg, C., VikMo, E., Olstorn, H., Varghese, M., Langmoen, I. A. y Nicolaissen, B. (2009). A comparison of epithelial and neural properties in progenitor cells derived from the adult human ciliary body and brain. Exp Eye Res 88, 30-38.

Monnin, J., Morand-Villeneuve, N., Michel, G., Hicks, D. y Versaux-Botteri, C. (2007). Production of neurospheres from mammalian Müller cells in culture. Neurosci Lett 421, 22-26.

Monzo, H. J., Park, T. I., Montgomery, J. M., Faull, R. L., Dragunow, M. y Curtis, M. A. (2012). A method for generating high-yield enriched neuronal cultures from P19 embryonal carcinoma cells. J Neurosci Methods 204, 87-103.

Moore, S. y Thanos, S. (1996). The concept of microglia in relation to central nervous system disease and regeneration. Progress Neurobiology 48, 441-460.

Morcos, Y. y Chang-Ling, T. (1997). Identification of oligodendrocyte precursors in the myelinated streak of the adult rabbit retina in vivo. Glia 21, 163-182. 
Moretti, A., Caron, L., Nakano, A., Lam, J. T. Bernshausen, A., Chen, Y., Qyang, Y., Bu, L., Sasaki, M., Martin-Puig, S., Sun, Y., Evans, S. M., Laugwitz, K. L. y Chien, K. R. (2006). Multipotent embryonic isl1+ progenitor cells lead to cardiac, smooth muscle, and endothelial cell diversification. Cell 127, 1151-1165.

Morris, A. C. y Fadool, J. M. (2005). Studying rod photoreceptor development in zebrafish. Physiol Behav 86, 306-313.

Morris, A. C., Scholz, T. L., Brockerhoff, S. E. y Fadool, J. M. (2008). Genetic dissection reveals two separate pathways for rod and cone regeneration in the teleost retina. Dev Neurobiol 68, 605-619.

Moshiri, A., McGuire, C. R. y Reh, T. A. (2005) Sonic hedgehog regulates proliferation of the retinal ciliary marginal zone in posthatch chicks. Dev Dyn 233, 66-75.

Mosmann, T. (1983). Rapid colorimetric assay for cellular growth and survival: application to proliferation and cytotoxicity assays. J Inmunol Methods 65, 5563.

Mothe, A. J., Zahir, T., Santaguida, C., Cook, D. y Tator, C. H. (2011). Neural stem/progenitor cells from the adult human spinal cord are multipotent and self-renewing and differentiate after transplantation. PLoS One 6, e27079.

Müller, H. (1851). Zur Histologie der Netzhaut. Z Wiss Zool 3, 234-237.

Müller, H. (1952). Bau und Wachstum der Netzhaut des Guppy (Lebistes reticulates). Zool Jb Abt allg Zool Physiol 63, 275-324.

Nag, T. C. y Bhattacharjee, J. (1989). Retinal organization in a hill stream cyprinid Crossochelius latius latius hamilton. Exp Biol 48:4, 197-202.

Nájera, C., Millán, J. M., Beneyto, M. y Prieto, F. (1995). Epidemiology of retinitis pigmentosa in the Valencian community (Spain). Genet Epidemiol 12, 37-46.

Nakano, T., Ando, S., Takata, N., Kawada, M., Muguruma, K., Sekiguchi, K., Saito, K., Yonemura, S., Eiraku, M. y Sasai, Y. (2012). Selfformation of optic cups and storable stratified neural retina from human ESCs. Cell Stem Cell 10, 771785 .

Negishi, K., Teranishi, T. y Kato, S. (1985). Retinal growth in carp of the same age: density and number of dopamine neurons. Brain Res 350, 125-131.

Negishi, K., Stell, W. K. y Takasaki, Y. (1990) Early histogenesis of the teleostean retina: studies using a novel immunochemical marker, proliferating cell nuclear antigen (PCNA/cyclin). Brain Res Dev Brain Res 55, 121-125.
Neumann, C. J. y Nüsslein-Volhard, C. (2000). Patterning of the zebrafish retina by a wave of sonic hedgehog activity. Science $\mathbf{2 8 9}, 2137-2139$.

Neves, J., Kamaid, A., Alsina, B. y Giraldez, F. (2007). Differential expression of Sox 2 and Sox 3 in neuronal and sensory progenitors of the developing inner ear of the chick. J Comp Neurol 503, 487-500.

Newman, E. y Reichenbach, A. (1996). The Müller cell: a functional element of the retina. Trends Neurosci 19, 307-312.

Ni Dhubhghaill, S. S., Cahill, M. T., Campbell, M., Cassidy, L., Humphries, M. M. y Humphries, P. (2010). The pathophysiology of cigarette smoking and age-related macular degeneration. $A d v$ Exp Med Biol 664, 437-446.

Nickerson, P. E., Emsley, J. G., Myers, T. y Clarke, D. B. (2007). Proliferation and expression of progenitor and mature retinal phenotypes in the adult mammalian ciliary body after retinal ganglion cell injury. Invest Ophthalmol Vis Sci 48, 5266-5275.

Nishina, S., Kohsaka, S., Yamaguchi, Y., Handa, H., Kawakami, A., Fujisawa, H. y Azuma, N. (1999). Pax6 expression in the developing human eye. Br J Ophthalmol 83, 723-727.

Nornes, S., Clarkson, M., Mikkola, I., Pedersen, M., Bardsley, A., Martinez, J. P., Krauss, S. y Johansen, T. (1998). Zebrafish contains two pax6 genes involved in eye development. Mech Dev 77, 185-196.

Nüsslein-Volhard, C. y Wieschaus, E. (1980). Mutations affecting segment number and polarity in Drosophila. Nature 287, 795-801.

Oda, K., Matsuoka, Y., Funahashi, A. y Kitano, H. (2005). A comprehensive pathway map of epidermal growth factor receptor signaling. Mol Syst Biol 1:2005.0010.

Oka, S., Honmou, O., Akiyama, Y., Sasaki, M., Houkin, K., Hashi, K. y Kocsis, J. D. (2004). Autologous transplantation of expanded neural precursor cells into the demyelinated monkey spinal cord. Brain Res 1030, 94-102.

Okamoto, S. y Takahashi, M. (2011). Induction of retinal pigment epithelial cells from monkey iPS cells. Invest Ophthalmol Vis Sci 52, 8785-8790.

Oliver, G., Sosa-Pineda, B., Geisendorf, S., Spana, E. P., Doe, C. Q. y Gruss, P. (1993). Prox 1, a prospero-related homeobox gene expressed during mouse development. Mech Dev 44, 3-16.

Olson, A. J., Picones, A., Julian, D. y Korenbrot, J. I. (1999). A developmental time line in a retinal slice from rainbow trout. J Neurosci Methods 93, $91-100$. 
Ornitz, D. M., Xu, J., Colvin, J. S., McEwen, D. G., MacArthur, C. A., Coulier, F., Gao, G. y Goldfarb, M. (1996). Receptor specificity of the fibroblast growth factor family. J Biol Chem 271, 15292-15297.

Osakada, F., Ikeda, H., Mandai, M., Wataya, T. Watanabe, K., Yoshimura, N., Akaike, A., Sasai, Y. y Takahashi, M. (2008). Toward the generation of rod and cone photoreceptors from mouse, monkey and human embryonic stem cells. Nat Biotechnol 26, 215-224.

Osterberg, N. y Roussa, E. (2009). Characterization of primary neurospheres generated from mouse ventral rostral hindbrain. Cell Tissue Res 336, 11-20.

Otteson, D. C., D'Costa, A. R. y Hitchcock, P. F (2001). Putative stem cells and the lineage of rod photoreceptors in the mature retina of the goldfish. Dev Biol 232, 62-76.

Otteson, D. C., Cirenza, P. F. y Hitchcock, P. F. (2002). Perstistent neurogenesis in the teleost retina: evidence for regulation by the growthhormone/insulin-like growth factor-I axis. Mech Dev 117, 137-149.

Otteson, D. C. y Hitchcock, P. F. (2003). Stem cells in the teleost retina: persistent neurogenesis and injury-induced regeneration. Vision Res 43, 927-936.

Owusu-Yaw, V., Kyle, A. L. y Stell, W. K. (1992) Effects of lesions of the optic nerve, optic tectum and nervus terminalis on rod precursor proliferation in the goldfish retina. Brain Res 576, 220-230.

Packard, D. J., Menzies, R. A. y Skalko, R. G. (1973). Incorporation of thymidine and its analogue, bromodeoxyuridine, into embryos and maternal tissues of the mouse. Differentiation 1, 397-405.

Palm, K., Salin-Nordström, T., Levesque, M. F. y Neuman, T. (2000). Fetal and adult human CNS stem cells have similar molecular characteristics and developmental potential. Brain Res Mol Brain Res 78, 192-195.

Pan, L., Deng, M., Xie, X. y Gan, L. (2008). ISL1 and BRN3B co-regulate the differentiation of murine retinal ganglion cells. Development 135, 1981-1990.

Panagis, L., Thanos, S., Fischer, D. y Dermon, C. R. (2005). Unilateral optic nerve crush induces bilateral retinal glial cell proliferation. Eur J Neurosci 21, 2305-2309.

Parrilla, M., Lillo, C., Herrero-Turrion, J., Arévalo, R., Lara, J. M., Aijón, J. y Velasco, A. (2009). Pax2 in the optic nerve of the goldfish, a model of continuous growth. Brain Reseach 1255, $75-88$
Parrilla-Monge, M. (2010). Estudio de las interacciones axón-neuroglía en la cabeza de nervio óptico de teleósteos durante el crecimiento continuado y la regeneración. Tesis Doctoral, Universidad de Salamanca.

Pei, Y. F. y Rhodin, J. A. (1970). The prenatal development of the mouse eye. Anat Rec 168, 105125 .

Perron, M., Kanekar, S., Vetter, M. L. y Harris, W. A. (1998). The genetic sequence of retinal development in the ciliary margin of the Xenopus eye. Dev Biol 199, 185-200.

Perron, M. y Harris, W. A. (2000). Retinal stem cells in vertebrates. Bioassays 22, 685-688.

Perron, M., Boy, S., Amato, M. A., Viczian, A., Koebernick, K., Pieler, T. y Harris, W. A. (2003). A novel function for hedgehog signalling in retinal pigment epithelium differentiation. Development 130, 1565-1577.

Pevny, L. H. y Lovell-Badge, R. (1997). Sox genes find their feet. Curr Opin Genet Dev 7, 338-344.

Pevny, L. H. y Nicolis, S. (2010). Sox2 roles in neural stem cells. Int $J$ Biochem Cell Biol 42, 421-424.

Plata-Salamán, C. R. (1991). Epidermal growth factor and the nervous system. Peptides 12, 653-663.

Poulat, F., Girard, F., Chevron, M. P., Gozé, C., Rebillard, X., Calas, B., Lamb, N. y Berta, P. (1995). Nuclear localization of the testis determining gene product SRY. J Cell Biol 128, 737-748.

Prasov, L. y Glaser, T. (2012). Dynamic expression of ganglion cell markers in retinal progenitors during the terminal cell cycle. Mol Cell Neurosci 50, 160-168.

Prelich, G., Tan, C. K., Kostura, M., Mathews, M. B., So, A. G., Downey, K. M. y Stillman, B. (1987). Functional identity of proliferating cell nuclear antigen and a DNA polymerase-delta auxiliary protein. Nature 326, 517-520.

Prigent, C. y Dimitrov, S. (2003). Phosphorylation of serine 10 in histone H3, what for? J Cell Sci 116, 3677-3685.

Prosser, J. y van Heyningen, V. (1998). Pax6 mutations reviewed. Hum Mutat 11, 93-108.

Püschel, A. W., Gruss, P. y Westerfield, M. (1992). Sequence and expression pattern of pax-6 are highly conserved between zebrafish and mice. Development 114, 643-651.

Qiu, G., Seiler, M. J., Thomas, B. B., Wu, K., Radosevich, M. y Sadda, S. R. (2007). Revisiting nestin expression in retinal progenitor cells in vitro and after transplantation in vivo. Exp Eye Res 84, 1047-1059. 
Raay, T. J. V., Moore, K. B., Iordanova, I., Steele, M., Jamrich, M., Harris, W. A. y Vetter, M. L. (2005). Frizzled5 signaling governs the neural potential of progenitors in the developing Xenopus retina. Neuron 46, 23-36.

Raballo, R., Rhee, J., Lyn-Cook, R., Leckman, J. F., Schwartz, M. L. y Vaccarino, F. M. (2000). Basic fibroblast growth factor (Fgf2) is necessary for cell proliferation and neurogenesis in the developing cerebral cortex. J Neurosci 20, 5012-5023.

Radtke, N. D., Aramant, R. B., Seiler, M. J., Petry, H. M. y Pidwell, D. (2004). Vision change after sheet transplant of fetal retina with retinal pigment epithelium to a patient with retinitis pigmentosa. Arch Ophthalmol 122, 1159-1165.

Rauch, U., Klotz, M., Maas-Omlor, S., Wink, E., Hänsgen, A., Hagl, C., Holland-Cunz, S. y Schäfer, K. H. (2006). Expression of intermediate filament proteins and neuronal markers in the human fetal gut. J Histochem Cytochem 54, 39-46.

Raymond, P. A. y Easter, S. J. (1983). Postembryonic growth of the optic tectum in goldfish II. Modulation of cell proliferation by retinal fiber input. $J$ Neurosci 3, 1092-1099.

Raymond, P. A. (1985). Cytodifferentiation of photoreceptors in larval goldfish: delayed maturation of rods. J Comp Neurol 236, 90-105.

Raymond, P. A. y Rivlin, P. K. (1987). Germinal cells in the goldfish retina that produce rod photoreceptors. Dev Biol 122, 120-138.

Raymond, P. A. (1991). Development of the Visual System. Capítulo: Cell determination and positional cues in the teleost retina: development of photoreceptors and horizontal cells. Cambridge: MIT Press, páginas 59-78.

Raymond, P. A. y Hitchcock, P. F. (2000). How the neural retina regenerates. Results Probl Cell Differ 31, 197-218.

Raymond, P. A., Barthel, L. K., Bernardos, R. L. y Perkowski, J. J. (2006). Molecular characterization of retinal stem cells and their niches in adult zebrafish. BMC Dev Biol 6:36.

Reichenbach, A. y Wohlrab, F. (1986). Morphometric parameters of Müller (glial) cells dependent on their topographic localization in the nonmyelinated part of the rabbit retina. a consideration of functional aspects of radial glia. J Neurocytol 15, 451-459.

Reichenbach, A. y Robinson, S. R. (1995). Neuroglia. Capítulo: Ependymoglia and ependymoglia-like cells. Oxford: University Press, páginas 58-84.

Remboutsika, E., Elkouris, M., Iulianella, A., Andoniadou, C. L., Poulou, M., Mitsiadis, T. A., Trainor, P. A. y Lovell-Badge, R. (2011). Flexibility of neural stem cells. Front Physiol 2:16.
Resibois, A. y Rogers, J. H. (1992). Calretinin in rat brain: an immunohistochemical study. Neuroscience 46, 101-134.

Reynolds, B. A. y Weiss, S. (1992). Generation of neurons and astrocytes from isolated cells of the adult mammalian central nervous system. Science 255, 1707-1710.

Rietze, R. L., Valcanis, H., Brooker, G. F., Thomas, T., Voss, A. K. y Bartlett, P. F. (2001). Purification of a pluripotent neural stem cell from the adult mouse brain. Nature 412, 736-739.

Robinson, J., Schmitt, E. A., Harosi, F. I., Reece, R. J. y Dowling, J. E. (1993). Zebrafish ultraviolet visual pigment: absortion spectrum, sequence and localization. Proc Natl Acad Sci USA 90, 6009-6012.

Robman, L., Mahdi, O., McCarty, C., Dimitrov, P., Tikellis, G., McNeil, J., Byrne, G., Taylor, H. y Guymer, R. (2005). Exposure to Chlamydia pneumoniae infection and progression of age-related macular degeneration. Am J Epidemiol 161, 10131019.

Rodriguez-Niedenführ, M., Papoutsi, M., Christ, B., Nicolaides, K. H., von Kaisenberg, C. S., Tomarev, S. I. y Wilting, J. (2001). Prox1 is a marker of ectodermal placodes, endodermal compartments, lymphatic endothelium and lymphangioblasts. Anat Embryol (Berl) 204, 399-406.

Rogers, J. H. (1987). Calretinin: a gene for a novel calcium-binding protein expressed principally in neurons. J Cell Biol 105, 1343-1353.

Roisen, F. J., Klueber, K. M., Lu, C. L., Hatcher, L. M., Dozier, A., Shields, C. B. y Maguire, S. (2001). Adult human olfactory stem cells. Brain Res $\mathbf{8 9 0}, 11-22$

Ross, H. H., Levkoff, L. H., Marshall, G. P., Caldeira, M., Steindler, D. A., Reynolds, B. A. y Laywell, E. D. (2008). Bromodeoxyuridine induces senescence in neural stem and progenitor cells. Stem Cells 26, 3218-3227.

Rouëdec, D. L., Rayner, K., Rex, M., Wigmore, P. M. y Scotting, P. J. (2002). The transcription factor cSox 2 and Neuropeptide Y define a novel subgroup of amacrine cells in the retina. J Anat 220, $51-56$.

Rowitch, D. H., St-Jacques, B., Lee, S. M. K., Flax, J. D., Snyder, E. Y. y McMahon, A. P. (1999). Sonic hedgehog regulates proliferation and inhibits differentiation of CNS precursors cells. $J$ Neurosci 19, 8954-8965.

Roy, S. y Ingham, P. W. (2002). Hedgehogs tryst with the cell cycle. J Cell Sci 115, 4393-4397. 
Safari, M., Nobakht, M., Roshandel, N. R., Ghazi, F. y Joghataee, M. T. (2009). Retinoic acid stimulate differentiation of hippocampal stem cells into opsin expressing cells in vitro. Pak J Biol Sci 12, $1200-1205$.

Sahlgren, C. M., Mikhailov, A., Hellman, J., Chou, Y. H., Lendahl, U., Goldman, R. D. y Eriksson, J. E. (2001). Mitotic reorganization of the intermediate filament protein nestin involves phosphorylation by cdc2 kinase. J Biol Chem 276, 16456-16463.

Sahlgren, C. M., Mikhailov, A., Vaittinen, S., Pallari, H. M., Kalimo, H., Pant, H. C. y Eriksson, J. E. (2003). Cdk5 regulates the organization of nestin and its association with p35. Mol Cell Biol 23, 5090-5106.

Sakagami, K., Ishii, A., Shimada, N. y Yasuda, K. (2003). RaxL regulates chick ganglion cell development. Mech Dev 120, 881-895.

Salvador-Silva, M., Vidal, S. y Villegas-Pérez, M. P. (2000). Microglial cells in the retina of $\mathrm{Ca}$ rassius auratus: effects of optic nerve crush. J Comp Neurol 417, 431-447.

Sánchez-González, R. (2009). Caracterización in vivo e in vitro de progenitores neurales en la retina de peces teleósteos. Tesis Doctoral, Universidad de Salamanca.

Santamaria, J. L., Marí-Beffa, M., Santos-Ruiz, L. y Becerra, J. (1996). Incorporation of bromodeoxyuridine in regenerating fin tissue of the goldfish carassius auratus. J Exp Zool 275, 300-307.

Scaffidi, P. y Bianchi, M. E. (2001). Spatially precise DNA bending is an essential activity of the sox2 transcription factor. J Biol Chem 276, 47296-47302.

Schilling, T. y Webb, J. (2007). Considering the zebrafish in a comparative context. J Exp Zool B Mol Dev Evol 308, 515-522.

Schmeer, C. W., Wohl, S. G. y Isenmann, S. (2012). Cell-replacement therapy and neural repair in the retina. Cell Tissue Res 349, 363-374.

Schmitt, E. y Kunz, Y. W. (1989). Retinal morphogenesis in the rainbow trout, Salmo gairdneri. Brain Behav Evol 34, 48-64.

Schmitt, E. A. y Dowling, J. E. (1994). Early eye morphogenesis in the zebrafish, Brachydanio rerio. $J$ Comp Neurol 344, 532-542.

Schneider, L. y d'Adda di Fagagna, F. (2012). Neural stem cells exposed to BrdU lose their global DNA methylation and undergo astrocytic differentiation. Nucleic Acids Res 40, 5332-5342.

Schneider, M., Marison, I. W. y von Stockar, U. (1996). The importance of ammonia in mammalian cell culture. J Biotech 46, 161-185.
Schnitzer, J. (1988). Astrocytes in the guinea pig, horse and monkey retina: their occurrence coincides with the presence of blood vessels. Glia 1, 74-89.

Scholes, J. H. (1979). Nerve fibre topography in the retinal projection to the tectum. Nature 278, 620624 .

Seki, M., Tanaka, T., Nawa, H., Usui, T., Fukuchi, T., Ikeda, K., Abe, H. y Takei, N. (2004). Involvement of brain-derived neurotrophic factor in early retinal neuropathy of streptozotocininduced diabetes in rats: therapeutic potential of brain-derived neurotrophic factor for dopaminergic amacrine cells. Diabetes 53, 2412-2419.

Seroogy, K. B., Gall, C. M., Lee, D. C. y Kornblum, H. I. (1995). Proliferative zones of postnatal rat brain express epidermal growth factor receptor mRNA. Brain Res 670, 157-164.

Servili, A., Bufalino, M. R., Nishikawa, R., Sanchez de Melo, I., Muñoz-Cueto, J. A. y Lee, L. (2009). Establishment of long term cultures of neural stem cells from adult sea bass, Dicentrarchus labrax. Comp Biochem Physiol A Mol Integr Physiol 152, 245-254.

Shan, S. F., Wang, L. F., Zhai, J. W., Qin, Y., Ouyang, H. F., Kong, Y. Y., Liu, J., Wang, Y. y Xie, Y. H. (2008). Modulation of transcriptional corepressor activity of prospero-related homeobox protein (Prox1) by SUMO modification. FEBS Lett 582, 3723-3728.

Sheedlo, H. J., Bartosh, T. J., Wang, Z., Srinivasan, B., Brun-Zinkernagel, A. M. y Roque, R. S. (2007). RPE-derived factors modulate photoreceptor differentiation: a possible role in the retinal stem cell niche. In Vitro Cell Dev Biol Anim 43, 361-370.

Shen, Q., Zhong, W., Jan, Y. N. y Temple, S. (2002). Asymmetric Numb distribution is critical for asymmetric cell division of mouse cerebral cortical stem cells and neuroblasts. Development 129, 48434853.

Sherpa, T., Fimbel, S. M., Mallory, D. E., Maaswinkel, H., Spritzer, S. D., Sand, J. A., Li, L., Hyde, D. R. y Stenkamp, D. L. (2008). Ganglion cell regeneration following whole-retina destruction in zebrafish. Dev Neurobiol 68, 166-181.

Shetty, A. K. y Turner, D. A. (1998). In vitro survival and differentiation of neurons derived from epidermal growth factor-responsive postnatal hippocampal stem cells: inducing effects of brain-derived neurotrophic factor. J Neurobiol 35, 395-425.

Shi, Y., Sun, G., Zhao, C. y Stewart, R. (2008). Neural stem cell self-renewal. Crit Rev Oncol Hematol 65, 43-53. 
Shintani, K., Shechtman, D. L. y S, G. A. (2009) Review and update: current treatment trends for patients with retinitis pigmentosa. Optometry $\mathbf{8 0}, 384-$ 401.

Shkumatava, A., Fischer, S., Müller, F., Strahle, U. y Neumann, C. J. (2004). Sonic hedgehog, secreted by amacrine cells, acts as a short-range signal to direct differentiation and lamination in the zebrafish retina. Development 131, 3849-3858.

Shkumatava, A. y Neumann, C. J. (2005). Shh directs cell-cycle exit by activating p57Kip2 in the zebrafish retina. EMBO Rep 6, 563-569.

Silverman, M. S. y Hughes, S. E. (1989). Photoreceptor transplantation in inherited and environmentally induced retinal degeneration: anatomy, immunohistochemistry and function. Prog Clin Biol Res 314, 687-704.

Singh, M. S. y MacLaren, R. E. (2011). Stem cells as a therapeutic tool for the blind: biology and future prospects. Proc Biol Sci 278, 3009-3016.

Singh, R. P., Shiue, K., Schomberg, D. y Zhou, F. C. (2009). Cellular epigenetic modifications of neural stem cell differentiation. Cell Transplant 18, $1197-1211$.

Sjöberg, G., Jiang, W. Q., Ringertz, N. R., Lendahl, U. y Sejersen, T. (1994). Colocalization of nestin and vimentin/desmin in skeletal muscle cells demonstrated by three-dimensional fluorescence digital imaging microscopy. Exp Cell Res 214, 447-458.

Smith, A. N., Miller, L. A., Radice, G., AsheryPadan, R. y Lang, R. A. (2009). Stage-dependent modes of Pax6-Sox2 epistasis regulate lens development and eye morphogenesis. Development 136, $2977-2985$.

Song, P. I., Matsui, J. I. y Dowling, J. E. (2008). Morphological types and connectivity of horizontal cells found in the adult zebrafish (Danio rerio) retina. J Comp Neurol 506, 328-338.

Soules, K. A. y Link, B. A. (2005). Morphogenesis of the anterior segment in the zebrafish eye. BMC Dev Biol 5, 12.

Spence, J. R., Madhavan, M., Ewing, J. D., Jones, D. K., Lehman, B. M. y Rio-Tsonis, K. D. (2004). The hedgehog pathway is a modulator of retina regeneration. Development 131, 4607-4621.

Stachowiak, M. K., Moffett, J., Maher, P., Tucholski, J. y Stachowiak, E. K. (1997). Growth factor regulation of cell growth and proliferation in the nervous system. a new intracrine nuclear mechanism. Mol Neurobiol 15, 257-283.

Stafford, M. R., Bartlett, P. F. y Adams, D. J. (2007). Purinergic receptor activation inhibits mitogen-stimulated proliferation in primary neurospheres from the adult mouse subventricular zone. Mol Cell Neurosci 35, 535-548.
Stanke, J. J., Lehman, B. y Fischer, A. J. (2008). Muscarinic signaling influences the patterning and phenotype of cholinergic amacrine cells in the developing chick retina. BMC Dev Biol 8:13.

Steinert, P. M., Marekov, L. N. y A, P. D. (1999). Molecular parameters of type [iv] alpha-internexin and type [iv]-type [iii] alpha-internexin-vimentin copolymer intermediate filaments. J Biol Chem 274, $1657-1666$.

Stell, W. K., Walker, S. E., Chohan, K. S. y Ball, A. K. (1984). The goldfish nervus terminales: a luteinizing hormone-releasing hormone and molluscan cardioexcitatory peptide immunoreactive olfactoretinal pathway. Proc Natl Acad Sci USA 81, 940-944.

Stenkamp, D., Frey, R., Prabhudesai, S. y Raymond, P. (2000). Function for hedgehog genes in zebrafish retinal development. Dev Biol 200, 238252 .

Stenkamp, D. L., Gregory, J. K. y Adler, R. (1993). Retinoid effects in purified cultures of chick embryo retina neurons and photoreceptors. Invest Ophthalmol Vis Sci 34, 2425-2436.

Stenkamp, D. L., Barthel, L. K. y Raymond, P. A. (1997). Spatiotemporal coordination of rod and cone photoreceptor differentiation in goldfish retina. $J$ Comp Neurol 382, 272-284.

Stenkamp, D. L. (2007). Neurogenesis in the fish retina. Int Rev Cytol 259, 173-224.

Stenkamp, D. L., Satterfield, R., Muhunthan, K., Sherpa, T., Vihtelic, T. S. y Cameron, D. A. (2008). Age-related cone abnormalities in zebrafish with genetic lesions in sonic hedgehog. Invest Ophtalmol Vis Sci 49, 4631-4640.

Stenkamp, D. L. (2011). The rod photoreceptor lineage of teleost fish. Prog Retin Eye Res 30, 395-404.

Stern, J. H. y Temple, S. (2011). Stem cells for retinal replacement therapy. Neurotherapeutics 8, 736-743.

Stoll, G. y Jander, S. (1999). The role of microglia and macrophages in the pathophysiology of the CNS. Progress Neurobiology 58, 233-247.

Straznicky, K. y Gaze, R. M. (1971). The growth of the retina in Xenopus laevis: an autoradiographic study. J Embryol Exp Morphol 26, 67-79.

Streisinger, G., Walker, C., Dower, N., Knauber, D. y Singer, F. (1981). Production of clones of homozygous diploid zebra fish (Brachydanio rerio). Nature 291, 293-296.

Strickler, A. G., Yamamoto, Y. y Jeffery, W. R. (2001). Early and late changes in pax6 expression accompany eye degeneration during cavefish development. Dev Genes Evol 211, 138-144. 
Stuermer, C. A. (1988). Retinotopic organization of the developing retinotectal projection in the zebrafish embryo. J Neurosci 8, 4513-4530.

Suga, A., Taira, M. y Nakagawa, S. (2009). LIM family transcription factors regulate the subtypespecific morphogenesis of retinal horizontal cells at post-migratory stages. Dev Biol 330, 318-328.

Sun, X., Jiang, R., Zhang, Y., Chen, M., Xiang, P., Qi, Y., Gao, Q., Huang, B. y Ge, J. (2009). Gene expression and differentiation characteristics in mice E13.5 and E17.5 neural retinal progenitors. Mol Vis 15, 2503-2514.

Sun, Y., Huang, Z., Liu, W., Yang, K., Sun, K., Xing, S., Wang, D., Zhang, W. y Jiang, X. (2012). Surface coating as a key parameter in engineering neuronal network structures in vitro. Biointerphases 7, 29-43.

Sütterlin, P., Williams, E. J., Chambers, D., Saraf, K., von Schack, D., Reisenberg, M., Doherty, P. y Williams, G. (2013). The molecular basis of the cooperation between EGF, FGF and $\mathrm{eCB}$ receptors in the regulation of neural stem cell function. Mol Cell Neurosci 52, 20-30.

Suzuki, T., Fujikura, K., Higashiyama, T. y K, T. (1997). DNA staining for fluorescence and laser confocal microscopy. J Histochem Cytochem 45, 4953 .

Svendsen, C. N., Fawcett, J. W., Bentlage, C. y Dunnett, S. B. (1995). Increased survival of rat EGF-generated CNS precursor cells using B27 supplemented medium. Exp Brain Res 102, 407-414.

Takabatake, T., Ogawa, M., Takahashi, T. C., Mizuno, M., Okamoto, M. y Takeshima, K. (1997). Hedgehog and patched gene expression in adult ocular tissues. FEBS Letters 410, 485-489.

Takahashi, K. y Yamanaka, S. (2006). Induction of pluripotent stem cells from mouse embryonic and adult fibroblast cultures by defined factors. Cell $\mathbf{1 2 6}$, 663-676.

Takahashi, K., Okita, K., Nakagawa, M. y Yamanaka, S. (2007). Induction of pluripotent stem cells from fibroblast cultures. Nat Protoc 2, 3081-3089.

Takeda, A., Nakano, M., Goris, R. C. y Funakoshi, K. (2008). Adult neurogenesis with 5-HT expression in lesioned goldfish spinal cord. Neuroscience 151, 1132-1141.

Taranova, O. V., Magness, S. T., Fagan, B. M., Wu, Y., Surzenko, N., Hutton, S. R. y Pevny, L. H. (2006). SOX2 is a dose-dependent regulator of retinal neural progenitor competence. Genes Dev 20, $1187-1202$.

Taupin, P. y Gage, F. H. (2002). Adult neurogenesis and neural stem cells of the central nervous system in mammals. J Neurosci Res 69, 745-749.
Taupin, P. (2007). BrdU immunohistochemistry for studying adult neurogenesis: paradigms, pitfalls, limitations, and validation. Brain Res Rev 53, 198-214.

Teranishi, T., Negishi, K. y Kato, S. (1983). Dopamine modulates s-potential amplitude and dyecoupling between external horizontal cells in carp retina. Nature 301, 243-246.

Thor, S., Ericson, J., Brännström, T. y Edlund, T. (1991). The homeodomain LIM protein Isl-1 is expressed in subsets of neurons and endocrine cells in the adult rat. Neuron 7, 881-889.

Thor, S. y Thomas, J. B. (1997). The Drosophila islet gene governs axon pathfinding and neurotransmitter identity. Neuron 18, 397-409.

Thummel, R., Kassen, S. C., Enright, J. M., Nelson, C. M., Montgomery, J. E. y Hyde, D. R. (2008). Characterization of Müller glia and neuronal progenitors during adult zebrafish retinal regeneration. Exp Eye Res 87, 433-444.

Thut, C. J., Rountree, R. B., Hwa, M. y Kingsley, D. M. (2001). A large-scale in situ screen provides molecular evidence for the induction of eye anterior segment structures by the developing lens. Dev Biol 231, 63-76.

Tibbetts, M. D., Samuel, M. A., Chang, T. S. y Ho, A. C. (2012). Stem cell therapy for retinal disease. Curr Opin Ophthalmol 23, 226-234.

Ting, A. Y., Lee, T. K. y MacDonald, I. M. (2009). Genetics of age-related macular degeneration. Curr Opin Ophthalmol 20, 369-376.

Tomarev, S. I., Sundin, O., Banerjee-Basu, S., Duncan, M. K., Yang, J. M. y Piatigorsky, J. (1996). Chicken homeobox gene Prox 1 related to Drosophila prospero is expressed in the developing lens and retina. Dev Dyn 206, 354-367.

Tomarev, S. I., Zinovieva, R. D., Chang, B. y Hawes, N. L. (1998). Characterization of the mouse Prox1 gene. Biochem Biophys Res Commun 248, 684-689.

Tremblay, P. y Gruss, P. (1994). Pax: genes for mice and men. Pharmacol Ther 61, 205-226.

Tritsh, G. L. y Moore, G. E. (1962). Spontaneous decomposition of glutamine in cell culture media. Exp Cell Res 28, 360-364.

Tropepe, V., Coles, B. L., Chiasson, B. J., Horsford, D. J., Elia, A. J., McInnes, R. R. y van der Kooy, D. (2000). Retinal stem cells in the adult mammalian eye. Science 287, 2032-2036.

Tsuruzoe, S., Ishihara, K., Uchimura, Y., Watanabe, S., Sekita, Y., Aoto, T., Saitoh, H., Yuasa, Y., Niwa, H., Kawasuji, M., Baba, H. y Nakao, M. (2006). Inhibition of DNA binding of Sox2 by the SUMO conjugation. Biochem Biophys Res Commun 351, 920-926. 
Tucker, B. A., Park, I. H., Qi, S. D., Klassen, H. J., Jiang, C., Yao, J., Redenti, S., Daley, G. Q. y Young, M. J. (2011). Transplantation of adult mouse iPS cell-derived photoreceptor precursors restores retinal structure and function in degenerative mice. PLoS One 6, e18992.

Tucker, M. S., Khan, I., Fuchs-Young, R., Price, S., Steininger, T. L., Greene, G., Wainer, B. H. y Rosner, M. R. (1993). Localization of immunoreactive epidermal growth factor receptor in neonatal and adult rat hippocampus. Brain Res 631, 65-71.

Turner, D. L. y Cepko, C. L. (1987). A common progenitor for neurons and glia persists in rat retina late in development. Nature 328, 131-136.

Uchiyama, H. (1990). Immunohistochemical subpopulations of retinopetal neurons in the nucleus olfactoretinalis in a teleost, the whitespotted (Hexagrammos stelleri). J Comp Neurol 293, 54-62.

Umino, Y. y Saito, T. (2002). Spatial and temporal patterns of distribution of the gap junctional protein connexin43 during retinal regeneration of adult newt. J Comp Neurol 454, 255-262.

Van Haesendonck, E., Marc, R. E. y Misotten, L. (1993). New aspects of dopaminergic interplexiform cell organization in the goldfish retina. J Comp Neurol 333, 503-518.

Velasco, A., Caminos, E., Vecino, E., Lara, J. M. y Aijón, J. (1995). Microglia in normal and regenerating visual pathways of the tench (Tinca tinca L., 1758; teleost): a study with tomato lectin. Brain Res 705, 315-324.

Velasco, A., Cid, E., Ciudad, J., Orfao, A., Aijón, J. y Lara, J. M. (2001). Temperature induces variations in the retinal cell proliferation rate in a cyprinid. Brain Res 913, 190-194.

Vihtelic, T. S., Yamamoto, Y., Sweeney, M. T. Jeffery, W. R. y Hyde, D. R. (2001). Arrested differentiation and epithelial cell degeneration in zebrafish lens mutants. Dev Dyn 222, 625-636.

von Holst, A., Egbers, U., Prochiantz, A. y Faissner, A. (2007). Neural stem/progenitor cells express 20 tenascin $\mathrm{C}$ isoforms that are differentially regulated by Pax6. J Biol Chem 282, 9172-9181.

Vossmerbaeumer, U., Kuehl, S., Kern, S., Kluter, H., Jonas, J. B. y Bieback, K. (2008). Induction of retinal pigment epithelium properties in ciliary margin progenitor cells. Clin Experiment Ophthalmol 36, 358-366.

Wachs, F. P., Couillard-Despres, S., Engelhardt, M., Wilhelm, D., Ploetz, S., Vroemen, M., Kaesbauer, J., Uyanik, G., Klucken, J., Karl, C., Tebbing, J., Svendsen, C., Weidner, N., Kuhn, H. G., Winkler, J. y Aigner, L. (2003). High efficacy of clonal growth and expansion of adult neural stem cells. Lab Invest 83, 949-962.
Wagner, H. (1990). The visual system of fish. Capítulo: Retinal structure of fishes. Londres: Chapman y Hall, páginas 109-157.

Wagner, H. J. y Wulle, I. (1992). Contacts of dopaminergic interplexiform cells in the outer retina of the blue acara. Vis Neurosci 9, 325-333.

Walcott, J. C. y Provis, J. M. (2003). Müller cells express the neuronal progenitor cell marker nestin in both differentiated and undifferentiated human foetal retina. Clin Experiment Ophthalmol 31, 246-249.

Wallace, V. A. (2008). Proliferative and cell fate effects of Hedgehog signaling in the vertebrate retina. Brain Res 1192, 61-75.

Wan, J., Zheng, H., Chen, Z. L., Xiao, H. L., Shen, Z. J. y Zhou, G. M. (2008). Preferential regeneration of photoreceptor from Müller glia after retinal degeneration in adult rat. Vision Res 48, 223234 .

Wang, Y., Dakubo, G. D., Thurig, S., Mazerolle, C. J. y Wallace, V. A. (2005). Retinal ganglion cell-derived sonic hedgehog locally controls proliferation and the timing of RGC development in the embryonic mouse retina. Development 132, 51035113.

Wehman, A. M., Staub, W., Meyers, J. R., Raymond, P. A. y Baier, H. (2005). Genetic dissection of the zebrafish retinal stem-cell compartment. Dev Biol 281, 53-65.

Weissman, I. L. (2000). Translating stem and progenitor cell biology to the clinic: barriers and opportunities. Science 287, 1442-1446.

Weitzman, J. B. (2002). Agonizing hedgehog. J Biol 1:7.

Wen, C. M., Cheng, Y. H., Huang, Y. F. y Wang, C. S. (2008). Isolation and characterization of a neural progenitor cell line from tilapia brain. Comp Biochem Physiol A Mol Integr Physiol 149, 167-180.

Werblin, F. S. y Dowling, J. E. (1969). Organization of the retina of the mudpuppy Necturus maculosus. II. intracelular recording. Neurophisiol 32, 339-355.

Whitney, I. E., Raven, M. A., Ciobanu, D. C., Poché, R. A., Ding, Q., Elshatory, Y., Gan, L., Williams, R. W. y Reese, B. E. (2011). Genetic modulation of horizontal cell number in the mouse retina. Proc Natl Acad Sci USA 108, 9697-9702.

Williamson, K. A., Hever, A. M., Rainger, J., Rogers, R. C., Magee, A., Fiedler, Z., Keng, W. T., Sharkey, F. H., McGill, N., Hill, C. J., Schneider, A., Messina, M., Turnpenny, P. D., Fantes, J. A., van Heyningen, V. y FitzPatrick, D. R. (2006). Mutations in SOX2 cause anophthalmia-esophageal-genital (AEG) syndrome. Hum Mol Genet 15, 1413-1422. 
Wilson, M. y Koopman, P. (2002). Matching SOX: partner proteins and co-factors of the SOX family of transcriptional regulators. Curr Opin Genet Dev 12, $441-446$.

Wissmüller, S., Kosian, T., Wolf, M., Finzsch, M. y Wegner, M. (2006). The high-mobility-group domain of Sox proteins interacts with DNA-binding domains of many transcription factors. Nucleic Acids Res 34, 1735-1744.

Wixon, J. (2000). Featured organism: Danio rerio, the zebrafish. Yeast 17, 225-231.

Wohl, S. G., Schmeer, C. W., Kretz, A., Witte, O. W. y Isenmann, S. (2009). Optic nerve lesion increases cell proliferation and nestin expression in the adult mouse eye in vivo. Exp Neurol 219, 175186.

Wolburg, H. (1980). Myelinated axons of ganglion cells in the retinae of teleosts. Cell Tissue Res 210, 517520 .

Wolburg, H. y Kurz-Isler, G. (1985). Dynamics of gap junctions between horizontal cells in the goldfish retina. Exp Brain Res 60, 397-401.

Woods, I. G., Kelly, P. D., Chu, F., Ngo-Hazelett, P., Yan, Y. L., Huang, H., Postlethwait, J. H. y Talbot, W. S. (2000). A comparative map of zebrafish genome. Genome Res 10, 1903-1914.

Wu, C. Y., Whye, D., Mason, R. W. y Wang, W. (2012). Efficient differentiation of mouse embryonic stem cells into motor neurons. J Vis Exp 64.

Wu, D., Schneiderman, T., Burgett, J., Gokhale, P., Barthel, L. y Raymond, P. (2001). Cones regenerate from retinal stem cells sequestered in the inner nuclear layer of adult goldfish retina. Invest Ophthalmol Vis Sci 42, 2115-2124.

Wu, S. M., Gao, F. y Maple, B. R. (2000). Functional architecture of synapses in the inner retina: segregation of visual signals by stratification of bipolar cell axon terminals. J Neurosci 20, 4462-4470.

Xiong, F., Gao, H., Zhen, Y., Chen, X., Lin, W., Shen, J., Yan, Y., Wang, X., Liu, M. y Gao, Y. (2011). Optimal time for passaging neurospheres based on primary neural stem cell cultures. Cytotechnology 63, 621-631.

Xu, H., Sta Iglesia, D. D., Kielczewski, J. L., Valenta, D. F., Pease, M. E., Zack, D. J. y Quigley, H. A. (2007a). Characteristics of progenitor cells derived from adult ciliary body in mouse, rat, and human eyes. Invest Ophthalmol Vis Sci 48, 16741682 .

Xu, S., Sunderland, M. E., Coles, B. L., Kam, A., Holowacz, T., Ashery-Padan, R., Marquardt, T., McInnes, R. R. y van der Kooy, D. (2007b). The proliferation and expansion of retinal stem cells require functional Pax6. Dev Biol 304, 713-721.
Xu, Y., Kimura, K., Matsumoto, N. y Ide, C. (2003). Isolation of neural stem cells from the forebrain of deceased early postnatal and adult rats with protracted post-mortem intervals. J Neurosci Res $\mathbf{7 4 ,}$ 533-540.

Xue, L., Ding, P., Xiao, L., Hu, M. y Hu, Z. (2010). Nestin, a new marker, expressed in Müller cells following retinal injury. Can J Neurol Sci 37, 643-649.

Xue, L. P., Lu, J., Cao, Q., Kaur, C. y Ling, E. A. (2006). Nestin expression in Müller glial cells in postnatal rat retina and its upregulation following optic nerve transection. Neuroscience 143, 117-127.

Yan, H., Zhang, X., Luo, S., Liu, H., Wang, X., Gao, Y., Wilson, J. X. y Huang, G. (2012). Effects of homocysteine on ERK signaling and cell proliferation in fetal neural stem cells In Vitro. Cell Biochem Biophys , doi 10.1007/s12013-012-9461-z.

Yan, Q., Liu, W. B., Qin, J., Liu, J., Chen, H. G., Huang, X., Chen, L., Sun, S., Deng, M., Gong, L., Li, Y., Zhang, L., Liu, Y., Feng, H., Xiao, Y., Liu, Y. y Li, D. W. (2007). Protein phosphatase-1 modulates the function of Pax-6, a transcription factor controlling brain and eye development. J Biol Chem 282, 13954-13965.

Yan, Q., Gong, L., Deng, M., Zhang, L., Sun, S., Liu, J., Ma, H., Yuan, D., Chen, P. C., Hu, X., Liu, J., Qin, J., Xiao, L., Huang, X. Q., Zhang, J. y Li, D. W. (2010). Sumoylation activates the transcriptional activity of Pax-6, an important transcription factor for eye and brain development. Proc Natl Acad Sci USA 107, 21034-21039.

Yang, J., Bian, W., Gao, X., Chen, L. y Jing, N. (2000). Nestin expression during mouse eye and lens development. Mech Dev 94, 287-291.

Yang, J., Gu, P., Menges, S. y Klassen, H. (2012). Quantitative changes in gene transcription during induction of differentiation in porcine neural progenitor cells. Mol Vis 18, 1484-1504.

Yang, P., Seiler, M. J., Aramant, R. B. y Whittemore, S. R. (2002). Differential lineage restriction of rat retinal progenitor cells in vitro and in vivo. $J$ Neurosci Res 69, 466-476.

Yazulla, S. y Studholme, K. M. (2001). Neurochemical anatomy of the zebrafish retina as determined by immnuocytochemistry. J Neurocytol 30, 551-592.

Young, R. W. y Bok, D. (1969). Participation of the retinal pigment epithelium in the rod outer segment renewal process. J Cell Bio 42, 392-403.

Young, R. W. (1971). Sheding of discs from rod outer segments in the rhesus monkey. J Ultrastruc Res 34, 190-203. 
Yu, J., Vodyanik, M. A., Smuga-Otto, K., Antosiewicz-Bourget, J., Frane, J. L., Tian, S., Nie, J., Jonsdottir, G. A., Ruotti, V., Stewart, R., Slukvin, I. I. y Thomson, J. A. (2007). Induced pluripotent stem cell lines derived from human somatic cells. Science 318, 1917-1920.

Yurco, P. y Cameron, D. A. (2005). Responses of Müller glia to retinal injury in adult zebrafish. Vis Res 45, 991-1002.

Zappone, M. V., Galli, R., Catena, R., Meani, N., De Biasi, S., Mattei, E., Tiveron, C., Vescovi, A. L., Lovell-Badge, R., Ottolenghi, S. y Nicolis, S. K. (2000). Sox2 regulatory sequences direct expression of a $\beta$-geo transgene to telencephalic neural stem cells and precursors of the mouse embryo, revealing regionalization of gene expression in CNS stem cells. Development 127, 2367-2382.

Zeng, Z., Yuan, X., Liu, G., Zeng, X., Zeng, X., Ng, H., Chen, H., Jiang, T., Akasaki, Y., Kessey, K., Black, K. L. y Yu, J. S. (2007). Manipulation of proliferation and differentiation of human bone marrow-derived neural stem cells in vitro and in vivo. J Neurosci Res 85, 310-320.

Zhang, X. M. y Yang, X. J. (2001). Temporal and spatial effects of Sonic hedgehog signaling in chick eye morphogenesis. Dev Biol 233, 271-290.

Zhang, Y., Porat, R. M., Alon, T., Keshet, E. y Stone, J. (1999). Tissue oxygen levels control astrocyte movement and differentiation in developing retina. Brain Res. Dev Brain Res 118, 135-145.

Zheng, K., Liu, T. Q., Dai, M. S., Ge, D., Li, X. Q., Ma, X. H. y Cui, Z. F. (2006). Comparison of different culture modes for long-term expansion of neural stem cells. Cytotechnology 52, 209-218.

Zheng, X. S., Yang, X. F., Liu, W. G., Shen, G., Pan, D. S. y Luo, M. (2007). A novel method for culturing neural stem cells. In Vitro Cell Dev Biol Anim 43, 155-158.

Zhou, L., Wang, W., Liu, Y., Fernández de Castro, J., Ezashi, T., Telugu, B. P., Roberts, R. M., Kaplan, H. J. y Dean, D. C. (2011). Differentiation of induced pluripotent stem cells of swine into rod photoreceptors and their integration into the retina. Stem Cells 29, 972-980.

Ziman, M. R., Rodger, J., Chen, P., Papadimitriou, J. M., Dunlop, S. A. y Beazley, L. D. (2001). Pax genes in development and maturation of the vertebrate visual system: implications for optic nerve regeneration. Histol Histopathol 16, 239-249.

Zuber, M. E., Gestri, G., Viczian, A. S., Barsacchi, G. y Harris, W. A. (2003). Specification of the vertebrate eye by a network of eye field transcription factors. Development 130, 5155-5167.

Zucker, C. L. y Dowling, J. E. (1987). Centrifugal fibres synapse on dopaminergic interplexiform cells in the teleost retina. Nature 330, 166-168.
Zupanc, G. K. (1999). Neurogenesis, cell death and regeneration in the adult gymnotiform brain. J Exp Biol 202, 1435-1446.

Zupanc, G. K. (2006). Neurogenesis and neuronal regeneration in the adult fish brain. J Comp Physiol A 192, 649-670.

Zupanc, G. K. (2008). Adult neurogenesis and neuronal regeneration in the brain of teleost fish. J Physiol Paris 102, 357-373. 
No has de esperar que Ítaca te enriquezca:

Ítaca te ha concedido ya un hermoso

viaje.

Sin ella, jamás habrías partido; mas no tiene otra cosa que ofrecerte.

Konstantínos Kaváfis

Itaca 